\title{
The Role of Islamic Microfinance in Poverty Alleviation and Environmental Awareness in Pasuruan, East Java, Indonesia: A Comparative Study
}

\author{
Dissertation \\ zur Erlangung des mathematisch-naturwissenschaftlichen Doktorgrades \\ "Doctor rerum naturalium" \\ der Georg-August-Universität Göttingen \\ im Promotionsprogramm Geowissenschaften / Geographie \\ der Georg-August University School of Science (GAUSS)
}

vorgelegt von

\section{Jaenal Effendi}

aus Pasuruan, Indonesia

Göttingen, 2013 
Betreuungsausschuss:

Prof. Dr. Heiko Faust

Prof. Dr. Crhistoph Dittrich

Mitglieder der Prüfungskommission

Referent: Prof. Dr. Heiko Faust

Korreferent : Prof. Dr. Christoph Dittrich

weitere Mitglieder der Prüfungskommission:

1. Prof. Dr. Gerhard Gerold

2. Prof. Dr. Karl-Heinz Pörtge

3. Dr. Jan Barkmann

4. Dr. Stefan Schwarze

Tag der mündlichen Prüfung: 17.07.2013

Author:

\section{Jaenal Effendi}

Contact:

E-mail: jaenfendi@gmail.com 


\section{SUMMARY}

Poverty is one of the greatest problems affecting developing countries. Socio-economic imbalances, created by both natural and artificial resource scarcity, restrict impoverished people's access to economic opportunities, limiting their purchasing power and empowerment. Environmental degradation is thus both a cause and effect of resource scarcity, as the poor are forced to seek increasingly environmentally and economically unsustainable methods of income generation, further marginalizing them.

Microfinance is known to be one of the best tools to combat poverty, as it allows the poor to empower both themselves and their communities through the creation and sustainment of their own businesses. Moreover, green microfinance, which combines the core concepts of microfinance with environmental awareness and preservation, aims to allow empowerment to occur without compromising the environment. Microfinance institutions (MFIs) use simple administrative procedures and the general abolishment of collateral to allow inhabitants of remote areas to access microfinance, whilst maintaining relationships with them and assisting with their financial and personal problems, educating them, and providing aid in the event of environmental disasters. Hence, microfinance is believed to have a positive effect on both poverty alleviation and environmental awareness.

In Indonesia, the country with the largest Muslim population in the world, Islamic finance, which was established in 1991 and saw rapid development during the politically volatile years of 1997 and 1998 (Seibel 2008), comprises commercial banks and banking units, Islamic rural banks, and Islamic financial cooperatives. Commercial Islamic banks focus on providing savings, financing, and insurance to medium and large businesses. People running small or micro businesses are thus restricted from receiving their services. Islamic microfinance, in the form of banking units, rural banks, and financial cooperatives, fills the void left by the commercial banks, enabling Indonesia's disadvantaged entrepreneurs to generate income on their own terms.

Most people in Pasuruan Regency, East Java, earn their incomes in the processing industry, agriculture, and trading. In this region, these sectors contribute more than any other to the total Gross Regional Domestic Product (BPS Pasuruan). However, most of them generally negatively affect the environment, through pollutive and chemically harmful practices, as well as a lack of skill and knowledge required to mitigate the negative impacts of these practices. These effects could be influenced by the microfinance institutions that finance their business activities and have a say in how their businesses are run. This is particularly the case with the Islamic MFIs in 
the region, in whom clients put a great deal of trust, and whose growth has been stimulated by Islamic finance’s own growth in Indonesia as a whole.

Although MFIs have seen significant development since the 1970s, not enough is known about them. While they have been shown to contribute to poverty alleviation, little is known about their simultaneous roles as facilitators of poverty alleviation and environmental development. Understanding this dynamic was of particular concern in Pasuruan Regency, as the peoples of our research sites appeared to show little regard for their environment whilst relying on MFIs to support their businesses. With their institutions failing to intervene in their destructive behaviors, there is an opening for environmental degradation to be countered with the use of MFIs as promoters of environmentally-friendly business practices. This study aimed to investigate the effect of Islamic microfinance institutions on the welfare of their clients, and whether they positively contribute to their environmental awareness. We examined the role of Islamic microfinance institutions in poverty alleviation and environmental awareness in three different areas of Pasuruan Regency, namely lowland, coastal, and upland. We further compared the impact of Islamic MFIs with that of conventional MFIs, to understand whether Islamic microfinance is consistent with other microfinance types or is able to stand out in its influence on clients' welfare, awareness, and behavior

Field work data was collected using qualitative and quantitative approaches. The qualitative approach comprised in-depth interviews, direct observations, and focus group discussions, while the quantitative approach comprised standardized and semi-structured questionnaires. Additionally, secondary data was obtained from banks and a number governmental organizations and officials and statistics offices. Triangulation and a logic model were used to evaluate and validate data before conducting both qualitative and quantitative data analyses. The qualitative analysis was used to describe the behavior of the people in our research area, particularly towards changes in their economic welfare and awareness of specific environmental issues after joining a microfinance institution. Quantitative data analyses consisted of frequency distributions and numerical summaries.

Our results revealed that both Islamic and conventional MFIs' primary concerns were selfsustainability, as they attempted to maintain financial performances and increase client bases within a regional context. Pondok pesantren, through their prevalence and their teachers and students' social programs, contributed to the development of Islamic MFIs in the lowland area by improving the public’s perceptions of Islamic microfinance. 
In the coastal area, Islamic MFIs managed to mitigate the challenges and poor perceptions created by their failed predecessors.

Meanwhile, Islamic MFIs in the upland area employed specific strategies to overcome challenges to their sustainability during periods of mass withdrawals. Conventional MFIs largely tailored their services to the needs of their clients, helping farmers acquire seeds and fertilizer in the lowland area, for example, or assisting fisheries and small entrepreneurs in the coastal area and helping clients grow, harvest, and process agroforestry products in the upland area.

The microfinance institutions in all three areas positively contributed to poverty alleviation, with a significant majority of MFI clients being able to develop their businesses after receiving financing or loans-more so those in the lowland and coastal areas than the upland area. In terms of business re-investment, the lowland area was found to have the lowest percentage of clients spending their surplus incomes on increasing business size or employee numbers; a factor that requires attention from the local government and MFIs if they are to contribute to selfempowerment.

Contrasting their impacts on poverty alleviation, both conventional and Islamic MFIs had negligible impacts on increasing the environmental awareness of their clients. Our analyses revealed that the MFIs in all three areas had problems with providing environmental training to their clients, failing to combat the already existent lack in awareness, and consequent accumulative degradation that occurred as a result. In all three research sites, more respondents reported that they did not receive training from their MFI than those who did. MFIs found it costly to dedicate a part of their net profits to environmental matters, but we found one costeffective way to contribute to environmental awareness was through informing them of the existence of the few training programs that were available.

There are still a limited number of empirical studies on Islamic microfinance's contributions to the poverty reduction of both the poor and the poorest. Our comparisons of the roles of Islamic and conventional MFIs in alleviating poverty revealed that both Islamic and conventional MFIs had a positive effect on poverty alleviation-Islamic MFIs slightly more than conventional ones. The screening system used by the Islamic MFIs, in particular their targeting of clients who were less inclined to use their funds for unrelated purposes, had a significant impact on their ability to avoid the lending risks encountered by the conventional MFIs, as well as the development of their clients' businesses. This was supported by key informants' observations that Islamic 
microfinance reduces the poverty level of clients, with their interest-free financing options and more flexible repayment plans being major factors. Islamic MFIs' redistributions of public donations to the poorest in the form of qard al hasan (credit without interest) also fortified their roles as important contributors to poverty reduction. Nevertheless, considering how integral the environment is to their clients' livelihoods, their environmental initiatives were merely enablers in their clients' destructive behaviors, and will only contribute to increased resource scarcity and more arduous poverty alleviation efforts. Islamic MFIs should therefore look at targeting environmentally-friendly businesses, in spite of their unfairly negative associations with cost and risk, whether through the use social funds or collaboration with the government. Green microfinance, which was unsuccessful in our study, should continue to be studied as a viable method of providing financial services to poor communities. Green Islamic microfinance, further, may be considered the next step in Islamic finance's development, as institutions attempt to empower individuals and communities in increasingly vulnerable environments. 


\section{ACKNOWLEDGMENT}

This dissertation would never been possible without the substantial support of many individuals and institutions.

First and foremost, I would like to thank Prof. Dr. Heiko Faust and Prof. Dr. Christoph Dittrich for their patient supervision and guidance, their kindness and empathy, and, most of all, for sharing their valuable insights and putting up with me related to the my study.

This dissertation could never been written without some helps of the people during collecting data in Pasuruan Regency: the directors and officials of Islamic microfinance institutions in the lowland area of Kraton subdistrict, the coastal area of Nguling subdistrict, and the upland area of Purwosari subdistrict. I would like to thank to head of DPRD, dinas Koperasi, BAPPEDA, and some village leaders within the research areas for their full support to make the hard data collection process easier.

This study would not have been possible without the financial support from the German Academic Exchange Service (DAAD); for that I am very thankful.

Thank you to my colleague in department of Human Geography with whom it was very enjoyable to do the study, and especially to Alex for his helps in guiding/proof reading manuscript's English.

Special thanks to the Indonesian Student Union (PPI) Göttingen for creating very nice atmosphere during my stay in the interesting city.

Finally, I would like to thank to my beloved wife Nur Zakiyah and my sons: M. Hazim Fikri, M. Hasbullah Huda, and M. Abdullah Mundzir for their unwavering support. I would also like to thank to my parents and family for their patience and support.

There are still many whom I have not mentioned for the sake of keeping this acknowledgment concise. For their inputs and contributions, I deeply appreciate and thank you all. 


\section{TABLE Of Contents}

Summary

Acknowledgments

Table of Contents

List of Tables

vi

List of Figures

ix

List of Abbreviations

xi

xiii

1 Introduction 1

1.1 Research Background $\quad 1$

1.2 Problem Description 4

1.3 Study Objectives 5

$\begin{array}{ll}1.4 \text { Structure of the Study } & 6\end{array}$

2 Literature Review and Conceptual Framework 9

2.1 Definition and Concepts of Microfinance 9

2.2 Conventional and Islamic Microfinance 12

2.2.1 Conventional Microfinance 13

2.2.2 Islamic Microfinance $\quad 15$

2.3 Asymmetric Information 18

$\begin{array}{lr}\text { 2.3.1 Adverse Selection and Moral Hazard } & 19\end{array}$

$\begin{array}{ll}\text { 2.3.2 Monitoring in Islamic MFIs } & 20\end{array}$

2.4 Assessing the Role of Microfinance on Poverty Alleviation 20

2.5 Assessing the Role of Microfinance on Environmental Awareness 23

2.6 Links between Microfinance, Poverty, and the Environment 24

3 Research Methods 29

3.1 Research Preparation and Permission $\quad 29$

$\begin{array}{ll}3.1 .1 \text { Preparation Stage } & 29\end{array}$

$\begin{array}{ll}\text { 3.1.2 Obtaining Research Permissions } & 29\end{array}$

3.2 Site Selection and Sampling Techniques $\quad 30$

3.3 Data Collection 31

3.3.1 Direct Interviews and Observations 32

3.3.2 In-depth Interviews and Focus Group Discussions 34

3.3.3 Other Data Sources 35

3.4 Data Evaluation and Validation: Triangulation and a Logic Model approach 36

3.5 Data Analyses 38

4 Overview of the Research Area $\quad 40$

$\begin{array}{ll}4.1 \text { Geography } & 40\end{array}$

4.2 Topography and Climate $\quad 42$

4.3 Demography, Hydrography, and Land Use $\quad 42$

4.4 Socio-Economics and Financial Institutions 43

5 Lowland Area $\quad 46$

5.1 Introduction 46

5.2 Overview of Research Area 46

5.3 Characteristics of Respondent Households 49 
5.4 Microfinance Institutions in the Lowland Area of Kraton Subdistrict 52

5.4.1 Islamic Microfinance Institutions: Pondok Pesantren as the Origin 54 of the Islamic Microfinance Institution

5.4.2 Conventional MFIs: Credit Schemes for Seed and Fertilizer 58 Acquirement

5.5 Microfinance and Poverty Alleviation 58

5.6 Microfinance and Environmental Awareness in the Lowland Area; Annual 63

Floods and Lack of Knowledge of the Local People

6 Coastal Area

68

6.1 Overview of Research Area 68

6.2 Characteristics of Respondent Households $\quad 72$

6.3 Microfinance Institutions in the Coastal Area of Nguling Subdistrict 75

6.3.1 Islamic Microfinance Institutions: From Convincing Customers to 77 an Award

6.3.2 Conventional Microfinance Institutions: an Imbalance in Credit 80

Demand Versus Number of Financial Institutions

6.4 Microfinance and Poverty Alleviation $\quad 80$

6.5 Microfinance and Environmental Awareness in the Coastal Area; the 85 Communities' Focus on Income Generation over Environmental Awareness

7 Upland Area

7.1 Overview of Research Area $\quad 91$

7.2 Characteristics of Respondent Households 94

7.3 Microfinance Institutions in the Upland Area of Puwosari Subdistrict 96

7.3.1 Islamic Microfinance Institutions: Special Approaches toward 99 Better Performance

7.3.2 Conventional Microfinance Institutions: Providing Financial 100 Services to Remote Villages

7.4 Microfinance and Poverty Alleviation in the Upland Area of Purwosari 100 Subdistrict

7.5 Microfinance and Environmental Awareness 105

8 The Effects of Islamic and Conventional MFIs on Poverty Alleviation and 110 Environmental Awareness: Geographical and MFI Type Comparisons

8.1 MFIs in the Three Research Areas: Geographical Comparisons 110

8.1.1 Characteristics of MFI clients in the Three Research Areas 110

$\begin{array}{ll}\text { 8.1.2 The Effect of MFIs on Poverty Alleviation } & 113\end{array}$

8.1.3 The Effect of MFIs on Environmental Awareness 117

8.2 Comparative Analysis between Islamic and Conventional MFI 121

$\begin{array}{ll}\text { 8.2.1 Respondent Characteristics } & 121\end{array}$

8.2.2 Client' Preferences: Savings versus Loan Services 123

8.2.3 Asymmetric Information 124

8.2.3.1 Financing/Loan Usage Contrary to What the Clients 125 Applied for

8.2.3.2 Financing/Loans Obtained on Behalf of Others 128

8.2.3.3 Lack of Information on Potential Clients’ Business Acumen 128

8.2.4 The Effects of Islamic and Conventional MFIs on Poverty 129 Alleviation

$\begin{array}{ll}\text { 8.2.4.1 Business Performance } & 129\end{array}$ 
8.2.4.2 Welfare' Indicators

8.2.5 The Effects of Islamic and Conventional MFIs on Environmental 140

Awareness

8.2.5.1 Training and Social Programs Provided by MFIs Related to

140

Environmental Issues

8.2.5.2 Knowledge and Behavior Changes on Specific

144

Environmental Issues after Joining MFIs

\section{Discussion}

9.1 Geographical Comparison between the Lowland, Coastal, and Upland

Areas’ Microfinance’s Impacts on Poverty Alleviation and Environmental

Awareness

9.1.1 Institutional Performance

151

9.1.2 The Effect of MFIs on Poverty Alleviation 152

9.1.3 The Effect of MFIs on Awareness of Specific Environmental Issues 154

9.2 A Comparative Analysis between Islamic and Conventional MFIs 157

9.2.1 Clients' Characteristics and Their Preferences in Saving and Loan 157

Services

9.2.2 Asymmetric Information

158

9.2.3 Islamic Microfinance and Its Effect on Poverty Alleviation 159

9.2.4 Islamic Microfinance and Its Effect on Environmental Awareness 163

9.2.4.1 Training and Social Programs Provided by the MFIs 163

9.2.4.2 Knowledge and Behaviour Changes in MFI Clients on 164

Specific Environmental Issues after Joining MFIs

10 Conclusions and Policy Implications 167

$\begin{array}{ll}10.1 \text { Conclusion } & 167\end{array}$

10.1.1 Geographical Comparison of the Effect of Islamic Microfinance 167 on Poverty Alleviation and Environmental Awareness

10.1.2 The Effects of Islamic and Conventional Microfinance on Poverty 169 Alleviation and Environmental Awareness

10.2 Policy Implications 


\section{LIST OF TABLES}

Table $\quad 1.1 \quad$ SMEs in Indonesia, 2009-2011 2

Table $\quad 1.2$ Growth of Islamic Banking in Indonesia, 2006-2012 4

Table $2.1 \quad$ Differences between conventional and Islamic MFIs 12

Table $\quad 4.1 \quad$ Loans provided by commercial and rural banks in 2009, sorted 44

by purpose of loan

Table $\quad 4.2$ Microfinance institutions in Pasuruan Regency 45

Table $\quad 5.1 \quad$ Education level of local people in research site 48

$\begin{array}{llll}\text { Table } & 5.2 & \text { Level of welfare in the research site } & 49\end{array}$

Table $\quad 5.3 \quad$ Economic activities of head of household 50

Table $\quad 5.4$ Education level of household's head 50

Table $\quad 5.5$ Age of each household's head 51

Table $\quad 5.6 \quad$ Number of family members per household 51

Table 5.7 Microfinance institutions 52

Table $5.8 \quad$ Number of students in various pondok pesantren 55

Table 5.9 The informal education of the respondents 56

Table 5.10 Respondents’ perceptions of IsMFIs 57

Table $\quad 5.11$ Respondents' perceptions of PLS schemes 57

Table $\quad 5.12$ Monthly household income and expenditure 59

Table 5.13 Cross tabulation between monthly household income and 60 expenditure

Table $\quad 5.14$ Cross tabulation between family size and income 61

Table $\quad 5.15$ Training on environmental issues provided by the MFIs 64

Table $\quad 5.16$ Social programs provided by the MFIs 65

Table 5.17 Problems faced by the respondents 65

Table 5.18 Reaction of the community to environmental damage 66

Table $\quad 6.1$ Number of rainy days, monthly rainfall, and daily average of $\quad 68$ rainfall

$\begin{array}{llll}\text { Table } & 6.2 & \text { Education level of local people in research site } & 71\end{array}$

$\begin{array}{llll}\text { Table } & 6.3 & \text { Level of welfare in the research site } & 72\end{array}$

Table $\quad 6.4 \quad$ Economic activities of head of household 72

Table $\quad 6.5$ Education level of household's head 73

Table $\quad 6.6 \quad$ Age of household's head 74

$\begin{array}{llll}\text { Table } & 6.7 & \text { Number of family members per household } & 74\end{array}$

Table $\quad 6.8$ Microfinance institutions 76

Table $\quad 6.9$ The informal education of the respondents 78

Table $\quad 6.10$ Monthly household incomes and expenditures 81

Table 6.11 Cross tabulation between monthly household income and 82 expenditure

Table $\quad 6.12$ Cross tabulation between family size and income 83

Table $\quad 6.13$ Training on environmental issues provided by the MFIs 85

Table $\quad 6.14$ Social programs provided by the MFIs 86

Table $\quad 6.15$ Problems faced by the respondents 86

Table $\quad 6.16$ Reaction of the community to environmental damage 88

Table $\quad 7.1 \quad$ Number of rainy days, monthly rainfall, and daily average of 91 rainfall 
$\begin{array}{llll}\text { Table } & 7.2 & \text { Education level of local people in research site } & 93\end{array}$

\begin{tabular}{lll} 
Table & 7.3 & Level of welfare in the research site \\
\hline
\end{tabular}

$\begin{array}{llll}\text { Table } & 7.4 & \text { Economic activities of head of household } & 94\end{array}$

Table $\quad 7.5$ Education level of household's head 95

Table $\quad$ 7.6 Age of each household's head 96

Table $\quad 7.7$ Number of family members per household 96

Table $\quad 7.8 \quad$ Microfinance institutions $\quad 97$

$\begin{array}{lll}\text { Table } & 7.9 & \text { The informal education of the respondents }\end{array}$

Table $\quad 7.10$ Monthly household income and expenditure 101

Table 7.11 Cross tabulation between monthly household income and 102 expenditure

Table $\quad 7.12$ Cross tabulation between family size and income 103

Table $\quad 7.13$ Training on environmental issues provided by the MFIs 105

Table $\quad 7.14$ Social programs provided by the MFIs 106

Table $\quad 7.15$ Problems faced by the respondents 107

Table 7.16 Reaction of the community to environmental damage 107

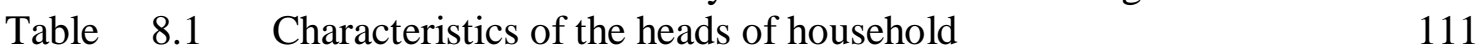

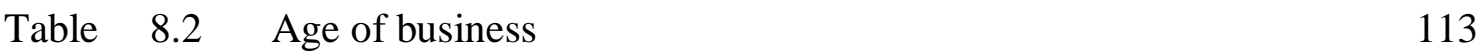

Table 8.3 Number of employees 114

Table $\quad 8.4$ MFIs' effects on business development 115

$\begin{array}{llll}\text { Table } & 8.5 & \text { Business development affecting family welfare } & 115\end{array}$

Table $\quad 8.6 \quad$ Item distributions impacted from business development 116

Table 8.7 Clients from different regions' knowledge on specific 117 environmental issues

Table $\quad 8.8 \quad$ Training on environmental issues provided by the MFIs 119

Table $\quad 8.9 \quad$ Social programs provided by the MFIs 119

Table $\quad 8.10$ Problems faced by the respondents 120

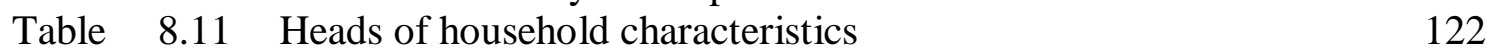

$\begin{array}{llll}\text { Table } 8.12 & \text { Usage of clients' financing/loans } & 125\end{array}$

Table $\quad 8.13$ Financing schemes adopted by the Islamic MFIs’ clients 127

Table $\quad 8.14$ MFIs' effects on clients' business 129

Table $\quad 8.15$ Effect of business development on family welfare 130

Table $\quad 8.16$ Effect of Islamic microfinance on poverty alleviation 130

Table $\quad 8.17$ Best strategies to reduce poverty 131

$\begin{array}{lll}\text { Table } & 8.18 & \text { Distribution of business profits }\end{array}$

$\begin{array}{llll}\text { Table } 8.19 & \text { Consumption of respondents after receiving financing/loans } & 134\end{array}$

$\begin{array}{llll}\text { Table } & 8.20 & \text { Health care improvement amongst clients of MFIs } & 135\end{array}$

$\begin{array}{lll}\text { Table } & 8.21 & \text { Education and information access }\end{array}$

$\begin{array}{lll}\text { Table } 8.22 & \text { Changes to client empowerment } & 137\end{array}$

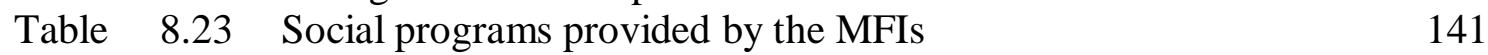

$\begin{array}{llll}\text { Table } & 8.24 & \text { Environmental problems faced by the respondents } & 141\end{array}$

$\begin{array}{llll}\text { Table } & 8.25 & \text { Reaction of MFI clients to environmental damage } & 142\end{array}$

Table $\quad 8.26$ Solutions to reducing environmental damage 143

Table $\quad 8.27$ Clients' knowledge on specific environmental issues 144

Table 8.28 Contribution of MFIs to knowledge of specific environmental 145

Table $\quad 8.29$ Changes to environmental awareness after joining an MFI 146 


\section{LIST OF FIGURES}

$\begin{array}{llll}\text { Figure } & 2.1 & \text { Segmentation of credit categories } & 10\end{array}$

$\begin{array}{lll}\text { Figure } 2.2 & \text { Geographical distribution of BMTs in Indonesia } & 17\end{array}$

$\begin{array}{lll}\text { Figure } & 2.3 & \text { Number of BPRS institutions and offices }\end{array}$

$\begin{array}{lll}\text { Figure } & 2.4 & \text { Conceptual framework of this study } 28\end{array}$

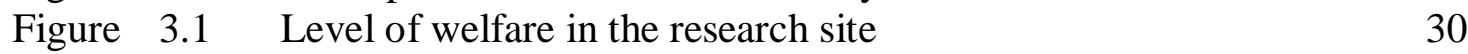

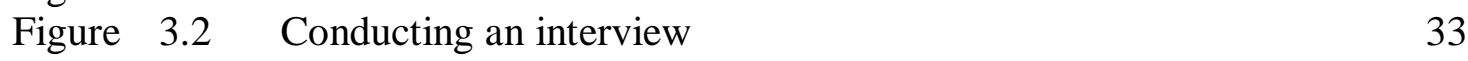

Figure 3.3 Direct observation of clients' transactions in an MFI 33

$\begin{array}{lll}\text { Figure } 3.4 \quad \text { An in-depth interview } & 35\end{array}$

Figure 3.5 A focus group discussion in a client's shop 35

Figure 3.6 The logic model of Islamic MFIs' roles in poverty 37

Figure 4.1 Map of East Java and the research area of Pasuruan 40

$\begin{array}{llll}\text { Figure } & 4.2 & \text { Lowland area of Kraton Subdistrict } & 41\end{array}$

$\begin{array}{lll}\text { Figure } & 4.3 \quad \text { Coastal area of Nguling Subdistrict } & 41\end{array}$

$\begin{array}{llll}\text { Figure } & 4.4 & \text { Upland area of Purwosari Subdistrict } & 42\end{array}$

$\begin{array}{lll}\text { Figure } & 5.1 & \text { Farmers growing rice }\end{array}$

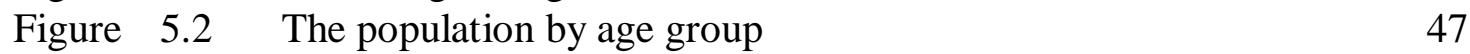

Figure 5.3 Income sources of the people in the lowland area of Kraton 48

$\begin{array}{llll}\text { Figure } & 5.4 & \text { Flooding in the lowland area of Kraton Subdistrict } & 49\end{array}$

Figure 5.5 Students of Pondok Pesantren Sidogiri 56

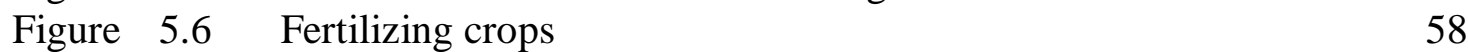

$\begin{array}{llll}\text { Figure } & 5.7 & \text { Embroidering clothes } & 58\end{array}$

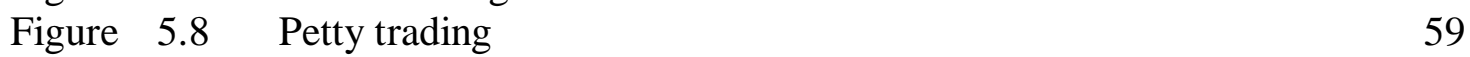

$\begin{array}{llll}\text { Figure } & 5.9 & \text { Traditional latrine over the river } & 63\end{array}$

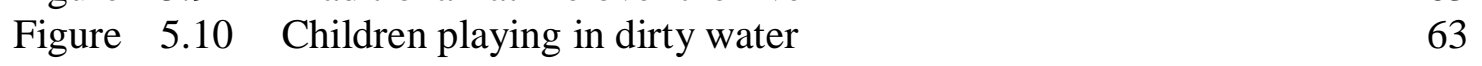

$\begin{array}{lll}\text { Figure } & 5.11 & \text { Traditional latrine }\end{array}$

Figure 5.12 Burning rice plant waste 66

$\begin{array}{llll}\text { Figure } & 6.1 & \text { Educational level of village officials in the research site } & 69\end{array}$

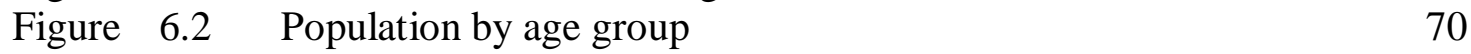

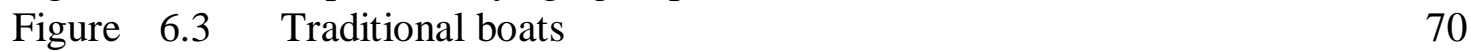

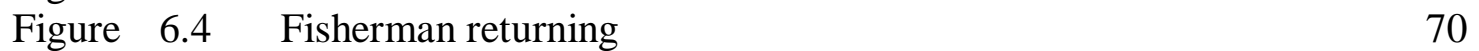

$\begin{array}{lll}\text { Figure } & 6.5 & \text { Traditional fish market }\end{array}$

$\begin{array}{lll}\text { Figure } & 6.6 & \text { Traditional fish market }\end{array}$

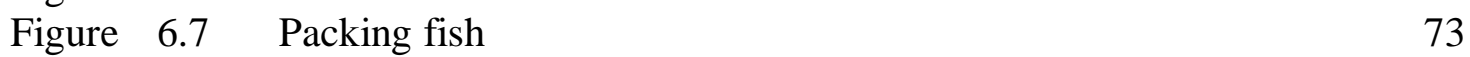

Figure $\quad 6.8$ Family members' involvement in fishing 75

$\begin{array}{llll}\text { Figure } & 6.9 & \text { The award presented to BMT MMU Nguling Subdistrict } & 79\end{array}$

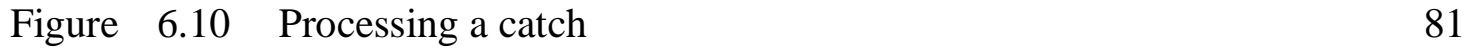

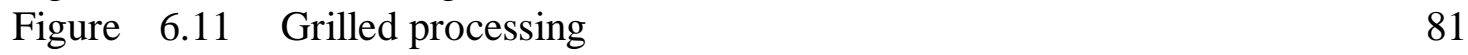

\begin{tabular}{lll} 
Figure & 6.12 & Drying fish around coastal trash \\
\hline
\end{tabular}

$\begin{array}{lll}\text { Figure } & 6.13 & \text { Smoke escaping from chimneys. }\end{array}$

Figure 6.14 The smoke produced by grilling fish. 87

$\begin{array}{lll}\text { Figure } & 6.15 & \text { Degradation of a mangrove forest resulting from tambak } \\ 88\end{array}$ expansion 
$\begin{array}{llll}\text { Figure } & 7.1 & \text { Education level of village officials in the research site } & 92\end{array}$

$\begin{array}{lll}\text { Figure } & 7.2 & \text { Population by age group }\end{array}$

$\begin{array}{lll}\text { Figure } & 7.3 & \text { Producing bricks }\end{array}$

$\begin{array}{lll}\text { Figure } & 7.4 & \text { Drying cassava chips }\end{array}$

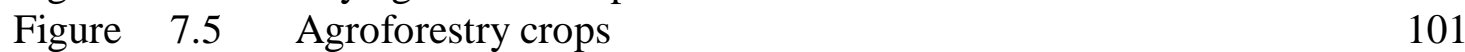

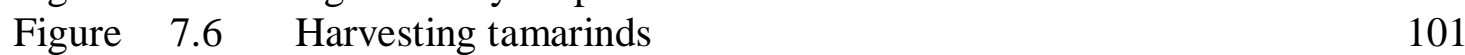

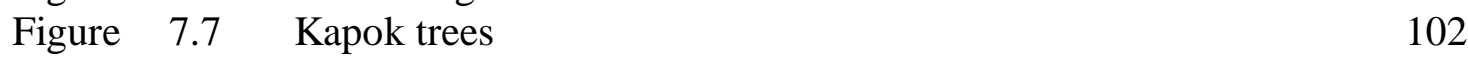

$\begin{array}{llll}\text { Figure } & 7.8 & \text { Societal garbage on a riverbank } & 106\end{array}$

Figure 8.1 Clients' preferences regarding savings and financing/loan 123 services

Figure 8.2 Flowchart of the effects of the MFIs' financing/loans on 133 poverty alleviation

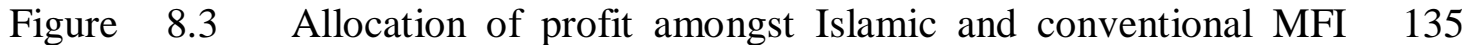
clients

$\begin{array}{llll}\text { Figure } & 8.4 & \text { Clients’ prioritization of health care } & 136\end{array}$

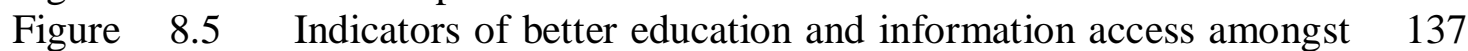
MFI clients

$\begin{array}{llll}\text { Figure } & 8.6 & \text { Preferred empowerment outcomes amongst MFI clients } & 138\end{array}$

Figure 8.7 Flowchart of the effects of MFIs' financing/loan on 148 environmental awareness 


\section{LIST OF ABBREVIATIONS}

\begin{tabular}{|c|c|}
\hline ABSINDO & $=$ Asosiasi BMT Se-Indonesia \\
\hline A.S.L & $=$ Above Sea Level \\
\hline AIM & $=$ Amanah Ikhtiar Malaysia \\
\hline BAPPEDA & = Badan Perencanaan Pembangunan Daerah \\
\hline BPR & $=$ Bank Perkreditan Rakyat \\
\hline BPRS & = Bank Perkreditan Rakyat Syariah \\
\hline ВРКB & $=$ Buku Pemilik Kendaraan Bermotor \\
\hline BMT & = Baitul Maal wa Tamwil \\
\hline BPS & $=$ Badan Pusat Statistik \\
\hline $\mathrm{BKD}$ & = Badan Kredit Desa \\
\hline BKKBN & = Badan Kependudukan dan Keluarga Berencana Nasional \\
\hline BRI & = Bank Rakyat Indonesia \\
\hline BRAC & = Bangladesh Rural Advancement Committee \\
\hline BRDB & = Bangladesh Rural Development Board's \\
\hline CPR & $=$ Common Pool Resources \\
\hline CGAP & $=$ Consultative Group to Assist the Poor \\
\hline DPRD & = Dewan Perwakilan Rakyat Daerah \\
\hline IsMFI & = Islamic Microfinance Institution \\
\hline Koppontren & = Koperasi Pondok Pesantren \\
\hline Kopinkra & $=$ Koperasi Industri Kerajinan \\
\hline Kopti & = Koperasi Pengusaha Tahu Tempe Indonesia \\
\hline Kopta & = Koperasi Kota \\
\hline KPRI & = Koperasi Pegawai Republik Indonesia \\
\hline Koppas & = Koperasi Pedagang Pasar \\
\hline KBPR & = Koperasi Bank Perkreditan Rakyat \\
\hline KPTR & = Koperasi Petani Tebu Rakyat \\
\hline KUD & = Koperasi Unit Desa \\
\hline KSP & $=$ Koperasi Simpan Pinjam \\
\hline MFI & $=$ Microfinance Institution \\
\hline NGOs & $=$ Non-Governmental Organizations \\
\hline
\end{tabular}


NU

PINBUK

PKK

PP

PLS

ROSCA

RDS

Rp

SMEs

SHG

UN

UNEP
= Nahdlatul Ulama

$=$ Pusat Inkubasi Bisnis Usaha Kecil

= Pembinaan Kesejahteraan Keluarga

$=$ Pondok Pesantren

$=$ Profit and Loss Sharing

$=$ Rotating Savings and Credit Associations

$=$ Rural Development Scheme

$=$ Rupiah

$=$ Small-Medium Enterprises

$=$ Self Help Groups

$=$ United Nation

$=$ United Nation Environment Program 


\section{INTRODUCTION}

\subsection{Research Background}

Socio-economic imbalance and resource scarcity, characterized by low competitiveness, high unemployment rates, economic stagnation, and the inappropriate use of natural resources, are two of the greatest causes of poverty. Poverty alleviation is thus historically linked to social development and its relation to the exploitation of natural resources, the primary livelihood of people in developing countries. Economic development and creating job opportunities are the aim of poverty alleviation programs. Some policies, such as enabling financial access to the poor, training, and capacity building, are important to increase the competitiveness of the poor for deriving their income, consequently contributing to poverty alleviation.

Access to microfinance institutions economically helps not only poor borrowers, but their community, as well (Khandker 2005). Poor people usually lack access to banks’ financial services, because of their stringent application requirements. Therefore, establishing microfinance institutions (MFIs) in developing communities may help poor entrepreneurs start new businesses, reduce people's vulnerability to external factors, and enable them to earn enough income to cover their expenditures. MFIs provide financial services using simple administrative procedures and generally without requiring collateral, avoiding the pitfalls of conventional banking whilst having an opportunity to improve the welfare of their clients. Furthermore, the reach of microfinance extends beyond urban areas, with MFIs commonly being found in remote areas and regularly maintaining relationships with their clients in these areas. Through these relationships, MFIs create a connection between themselves and clients, enabling them to assist with clients' financial problems, educate them on environmental matters, and join in providing aid to communities following natural disasters. Some of these disasters-or their consequences-are avoidable through proper environmental maintenance; however, without access to financial institutions and thus greater financial opportunity, compounded by limited skills, knowledge, and competitiveness, the poor are prevented from seeking occupations that are not dependent on the exploitation of the environment. Overexploitation of natural resources usually occurs as a result of low environmental awareness, creating ecosystem and environmental degradation. Hence, microfinance, with its ability to connect with clients and more effectively run social programs dedicated to education and environmental training, is considered to have an important role in alleviating poverty and reducing environmental degradation. 
Donors, governments, and NGOs worldwide have become aware of microfinance's important potential roles and prospects (Hermes and Lensink 2011). The United Nations (UN) declared 2005 as the International Year of Microcredit, which is essential to reaching their millennium development goals, one of which is halving the world's poverty rate by 2015. Furthermore, MFIs also have the opportunity to positively contribute to ensuring environmental sustainability, one of the UN's other millennium development goals.

Microfinance, according to Lashley (2004), is a concept that has been growing in popularity ever since the establishment of Grameen Bank in Bangladesh in the early-1970s. Since then, MFIs have spread all over the world as a means of both poverty alleviation and microenterprise development.

In Indonesia, microfinance is an essential component of enabling the poor to take part in economic activities, since they are excluded from formal banking. According to Ledgerwood (1999, 2), microfinance clients consist of self-employed farmers, non-agricultural workers, as well as low-income entrepreneurs. They generally generated income as traders, street vendors, small farmers, service providers, craftsmen, or small producers. Microfinance programs help clients generate income through the creation of new jobs, whether in micro, small, or medium enterprises (SMEs), consequently reducing unemployment rates.

Table 1.1: SMEs in Indonesia, 2009-2011.

\begin{tabular}{|c|c|c|c|c|c|c|}
\hline \multirow{2}{*}{ Indicators } & \multicolumn{2}{|l|}{2009} & \multicolumn{2}{|l|}{2010} & \multicolumn{2}{|l|}{2011} \\
\hline & Total & $\%$ & Total & $\%$ & Total & $\%$ \\
\hline \multicolumn{7}{|c|}{ Enterprise Scale (unit) } \\
\hline Micro & $52,176,795$ & 98.88 & $53,207,500$ & 98.85 & $54,559,969$ & 99.00 \\
\hline Small & 546,675 & 1.04 & 573,601 & 1.07 & 602,195 & 1.09 \\
\hline Medium & 41,133 & 0.08 & 42,631 & 0.08 & 44,280 & 0.08 \\
\hline Large & 4,677 & 0.01 & 4,838 & 0.01 & 4,952 & 0.01 \\
\hline \multicolumn{7}{|c|}{ Employees (people) } \\
\hline Micro & $90,012,694$ & 91.03 & $93,014,759$ & 90.98 & $94,957,797$ & 90.77 \\
\hline Small & $3,521,073$ & 3.56 & $3,627,164$ & 3.55 & 3,919,992 & 3.75 \\
\hline Medium & $2,677,565$ & 2.71 & $2,759,852$ & 2.70 & $2,844,669$ & 2.72 \\
\hline Large & $2,674,671$ & 2.70 & 2,839,711 & 2.78 & $2,891,224$ & 2.76 \\
\hline \multicolumn{7}{|c|}{$\begin{array}{l}\text { Value added at constant } \\
\text { price } 2000 \text { (Rp billion) }\end{array}$} \\
\hline Micro & $682,259,8$ & 32.66 & $719,070,2$ & 32.42 & $761,228,8$ & 32.02 \\
\hline Small & $224,311,0$ & 10.74 & $239,111,4$ & 10.78 & $261,315,8$ & 10.99 \\
\hline Medium & $306,028,5$ & 14.65 & $324,390,2$ & 14.63 & $346,781,4$ & 14.59 \\
\hline Large & $876,459,2$ & 41.95 & $935,375,2$ & 42.17 & $1.007,784,0$ & 42.40 \\
\hline
\end{tabular}

Source: Ministry of Cooperative and Small and Medium Enterprises (2012). 
A significant majority of Indonesians derived their incomes from a micro enterprise; $98.88 \%$ in 2009, 98.95\% in 2010, and 99\% in 2011 (Table 1.1). Conversely, just 0.01\% in every year were large enterprises. Prevalence of enterprises decreased with the increase in their scale; thus, small enterprises accounted for $1.04 \%$ in $2009,1.07 \%$ in 2010 , and $1.09 \%$ in 2011 , while medium enterprises accounted for $0.08 \%$ in each year. On the micro scale, these percentages had a significant effect on job opportunities, with 91.03\% (2009), 90.98\% in (2010), and 90.77\% (2011) of people being employed in micro enterprises. On the other hand, just $2.70 \%$ in 2009, 2.78\% in 2010, and 2.76\% in 2011 were employed in large enterprises. Therefore, micro, small, and medium enterprises made significant contributions to the labor market. However, large scale enterprises made more significant contributions to value added at constant price $(41.95 \%$ in 2009; 42.17\% in 2010; $42.40 \%$ in 2011) compared with micro scale enterprises (32.66\% in 2009; $32.42 \%$ in 2010; 32.02\% in 2011). These data indicate that micro, small, and medium enterprises made less contributions to total value added, but had a greater effect on employment generation. Hill (2001) revealed the important role SMEs play in Indonesia's economy, particularly in supporting businesses. Micro enterprises are useful for reducing the number of poor people in Indonesia, where poverty is still high.

Some MFIs provide business development services to clients, such as skill and basic business training, or social services, such as health care, education, and literacy training. These programs are meant to improve the ability of MFI clients to increase their income through the establishment of microenterprises (Ledgerwood 1999, 63).

Access to microfinance can have a positive effect on environmental sustainability. Zeller et al. (2000) found that, in Madagascar, access to financial institutions positively affected lowland rice yields and upland soil fertility, and concluded that promoting microfinance institutions positively impacted agricultural productivity, poverty, and natural resources. Microfinance institutions that focus on allocating their financial services to environmental matters are considered to be conducting "green microfinance”, which positively contributes to the sustainable development of the environment (Allet and Hudon 2013). Additionally, Anderson, Locker, and Nugent (2002), in an exploration of how lending to the very poor and women, and using group lending techniques, affected the sustainable use of common pool resources (CPR), found that microcredit can increase environmental awareness and may help reduce CPR degradation.

Islamic finance has been emergent in Indonesia, the country with the largest Muslim population in the world, since 1991. Forms of Islamic finance include Islamic commercial banks and 
banking units, Islamic rural banks, and Islamic financial cooperatives. The development of these institutions has increased since the inception of Islamic finance (Table 1.2).

Table 1.2: Growth of Islamic Banking in Indonesia, 2006-2012.

\begin{tabular}{lrrrrrrr}
\hline Type of Islamic bank & 2006 & 2007 & 2008 & 2009 & 2010 & 2011 & 2012 \\
\hline Commercial bank & 3 & 3 & 5 & 6 & 11 & 11 & 11 \\
Commercial banking unit & 20 & 26 & 27 & 25 & 23 & 24 & 24 \\
Rural credit bank & - & 114 & 131 & 139 & 150 & 155 & 158 \\
\hline
\end{tabular}

Sources: Indonesian Banking Statistics, Bank Indonesia.

The development of Islamic banking in Indonesia was followed by financial cooperatives called BMT (baitul maal wa tamwil), which grew rapidly, particularly during the crisis years of 1997 and 1998 (Seibel 2008). Rahman (2010), in a study on Islamic microfinance and its impact on rural poverty alleviation, found that Islamic microfinance significantly impacted household income, the productivity of crops and livestock, and employment opportunities.

\subsection{Problem Description}

In Pasuruan Regency, East Java, processing, agriculture, and services (including hotels and restaurants) are the main sectors through which people derive their income. These sectors contribute 30.95\%, 24.38\%, and 20.95\%, respectively, to the total Gross Regional Domestic Product (BPS Kabupaten Pasuruan 2010). The agricultural sector, comprising food and non-food crops, livestock, and fishing, has supported the growth of the processing industry, and consequently, the service sector, as well. However, the economic actors in this area still face some problems related to the limitation of financial resources. Poor potential borrowers of formal institutions and banks are usually not able to provide certain application requirements, such as collateral.

Additionally, those economic sectors generally affect the environment, as most of the people working in them lack the skills and knowledge required to mitigate the negative impact of their business on the environment.

The establishment of MFIs in this area is considered to have had a positive effect on helping people to start new businesses or develop an existing one (Bansal 2012). Easy requirements, simple administration, and a wider variety of financing/credit schemes allow for greater access to financial services. Furthermore, the growth of Islamic financial institutions in Indonesia has spurred further development in the already increasing number of Islamic microfinance institutions in Pasuruan Regency. These institutions have been well-received by the communities 
in which they are situated, as shown in the levels of trust and loyalty of their clients, and continuing growth of their client bases. The strong influence of Islamic culture in the communities, characterized by the establishment of many Islamic boarding schools (pondok pesantren), supported the development of the Islamic microfinance institutions in this area. Their rapid development was also aided by the institutions' competitive approaches toward lending, such as providing equal opportunities to all prospective clients, sharing in risk, refusing collateral, and offering soft loans like qard al hasan (credit without interest), as well as their greater investment in the success of their clients' businesses.

Sustainable development is possible if MFIs, non-governmental organizations (NGOs), and governments collaborate to find the best strategies to mitigate the negative effects of clients' businesses on the environment. Empirical studies on the connection between microfinance and environmental awareness may prove meaningful, particularly for decision-makers.

Some studies have shown the positive effects of microfinance on poverty alleviation, especially in developing countries (Ahlin, Lin, and Maio 2011; Jegede, Kehinde, and Akinlabi 2011; Montgomery and Weiss 2011; Hulme 2000; Khandker 2000). However, there are still a limited number of studies that investigate the role of Islamic microfinance in reducing poverty. Additionally, although MFIs have seen significant development since the 1970s, there have been few studies into Islamic MFIs' simultaneous roles of alleviating poverty and increasing environmental awareness. This was of particular concern in our research, as the peoples of our research sites appeared to show little regard for their environment and generally relied on Islamic MFIs as a vehicle to support their businesses, creating an opening for MFIs to use this reliance to promote environmentally-friendly business practices.

\subsection{Study Objectives}

The intention of this study is to investigate the effect of Islamic MFIs on the welfare level of their clients, and whether they positively contribute to environmental awareness. To achieve these aims, we examined the role of Islamic microfinance institutions in poverty alleviation and environmental awareness in three different areas of Pasuruan Regency, namely lowland, coastal, and upland. As a comparison, we also looked at what impacts conventional MFIs had on these issues.

Our research questions are:

1. What are the characteristics and livelihoods of the MFIs' clients within the three different areas? 
2. How well do the Islamic and conventional MFIs perform in the three research areas?

3. What effects do both Islamic and conventional MFIs have on poverty alleviation in the three research areas?

4. What effects do both Islamic and conventional MFIs have on environmental awareness in the three different areas?

5. What are the differences and similarities of MFIs in the three research areas regarding poverty alleviation and environmental awareness?

6. Are there differences between the Islamic and conventional MFIs regarding asymmetric information?

7. How do the Islamic MFIs affect the development of their clients' businesses, and how do they compare with the conventional MFIs?

8. Was there a change in the welfare of Islamic MFI clients after receiving financing from their institution?

9. What are the implications of Islamic and conventional MFIs' roles in reducing poverty and increasing environmental awareness?

\subsection{Structure of the Study}

This manuscript is organized into 10 chapters. Chapters 4, 5, 6, and 7 are all connected in focusing on our research areas; Chapter 4 overall, and the latter three specifically on each research site.

Chapter 1, our introduction, provides the research background of our study, followed by a description of the problems in our research areas, and the aims of the study.

Chapter 2 presents the theoretical consideration and conceptual framework of the study, comprising the definition and concept of microfinance and the differences between Islamic and conventional microfinance. This chapter also presents the reasons for the Islamic MFIs' monitoring systems, some studies concerning the impacts of microfinance on poverty alleviation and environmental awareness, and the links between microfinance, poverty, and the environment. In the final part of the chapter, we propose a conceptual framework to guide the empirical analysis of the study.

Chapter 3 details the research methods. We describe the data collection process, which consisted of research site selection, respondent selection, and sampling procedure. We employ a combination of qualitative and quantitative analyses of the research data. In the qualitative approach, we use several methods of data collection, evaluation and validation, and empirical 
analysis. The quantitative approach is intended to support the findings of the qualitative data, including quantifying the qualitative data.

Chapter 4 provides the overview of the research areas, which are situated in Pasuruan Regency, as well as their geographical condition, and socio-economic development. Brief information on the contribution of the financial sector to the Gross Regional Domestic Product is also presented in this chapter.

Chapter 5 contains the general analysis of the lowland area of Kraton Subdistrict. The first subchapter presents a short introduction to all three different areas (lowland, coastal, and upland). The descriptions of the lowland area and respondent characteristics presented in this chapter assist in understanding the situation and conditions of the study area. This chapter also details the historical development of Islamic and conventional microfinance within the region, followed by the descriptive and in-depth analysis of microfinance's effects on empowering clients economically and their environmental awareness.

Chapter 6 presents the analysis of the coastal area of Nguling Subdistrict, with an overview of the research area, characteristics of respondents and their households, and the historical development of both Islamic and conventional microfinance in the region. This chapter also provides descriptive, as well as in-depth, analysis based on primary and secondary data regarding the effects of microfinance on alleviating the poverty and increasing the environmental awareness of their clients.

Chapter 7 presents the analysis of the upland area of Purwosari Subdistrict. First, an overview of the research area is provided, followed by analysis of the respondent characteristics, and a look at the historical development of Islamic and conventional microfinance institutions in the area. The impacts of microfinance on poverty alleviation and environmental awareness are presented in the last part of the chapter.

Chapter 8 focuses on in-depth analysis of the two different microfinance institution types (conventional and Islamic) in the three research areas. First, a geographical comparison is made, which comprises analyzing the different characteristics of microfinance clients in the three different areas, as well as the different institutions' effects on poverty alleviation and environmental awareness in each area. Empirical analyses of the Islamic and conventional microfinance institutions follow. This subchapter comprises analyses of respondent characteristics, the preferences of microfinance clients regarding savings and loan services, 
asymmetric information, and the effects of Islamic and conventional microfinance on poverty alleviation and environmental awareness.

Chapter 9 discusses the study findings in comparison with previous studies, focusing on the role of Islamic microfinance in poverty alleviation and environmental awareness. A geographical comparison regarding the role of microfinance in both poverty alleviation and environmental awareness is presented in this chapter. The role of Islamic microfinance in reducing poverty as well as increasing environmental awareness is also discussed.

Finally, Chapter 10 summarizes the research findings and presents the policy implications of the study. 


\section{LITERATURE REVIEW AND CONCEPTUAL FRAMEWORK}

This chapter reviews several theoretical and empirical considerations intended to support the analysis of the roles of Islamic microfinance institutions in poverty alleviation and environmental awareness. We also develop a conceptual framework as a basis for the empirical analysis.

The first subchapter focuses on the definition and concept of microfinance, a comparative overview of Islamic and conventional institutions, and the concept of asymmetric information. Then, previous assessments of the microfinance's impacts on reducing poverty and increasing environmental awareness are also reviewed. In addition, this chapter also elaborates on the links between microfinance, poverty, and the environment.

\subsection{Definition and Concepts of Microfinance}

The establishment of microfinance is proposed as a method of providing financial services to low-income households who lack access to commercial banks. It is considered an effective tool to combat poverty, especially in developing countries. Ledgerwood $(1999,1)$ defines microfinance as the provision of financial services, largely in the form of savings and credit, to low-income people. Other forms of services include insurance and social intermediation, and entrepreneurial training, such as in financial literacy and management. Furthermore, in stating that microfinance is not a form of banking, but a development tool, she specifies that the practice usually involves small loans, informal appraisal, collateral substitutes, performance-based access to repeat and larger loans, streamlined loan disbursement and monitoring, and secure savings products. Brandsma and Burjorjee (2004, 7), meanwhile, similarly characterize microfinance as:

1. Focus on poor entrepreneurs who lack access to commercial banks.

2. Simple and convenient access to small, short term, and repeat loans, with the use of substitute collateral and informal appraisal of investments and borrowers.

3. Provision of voluntary savings services that facilitate small deposits, with convenient collections and easy fund access.

According to Berger, Goldmark, and Sanabria (2006, 3-4), a requisite of microfinance is knowledge of customers' characteristics. Usually, MFI clients have informal and family-based operations. These micro enterprises, and their owners and employees, lack proper accounting and management; two factors that feature prominently in commercial banks' requirements. 
Asian Development Bank (2000, 2) and La Torre and Gianfranco (2006, 5-6) categorize microfinance into three types, in terms of governmental regulation:

1. Informal. Unregulated or uncontrolled by regional authorities. Institutions include selfhelp groups, credit associations, families (relatives), and individual money lenders.

2. Semi-formal. Registered entities and subject to all financial institution regulations. Although they provide several financial services, institutions do not receive deposits or grant loans. Hence, they operate as financial intermediaries, but are not regulated as commercial banks. Institutions include financial NGOs, financial cooperatives, and postal savings banks.

3. Formal. Can be divided into three groups: microfinance divisions of commercial banks, rural banks, and cooperatives. Institutions are regulated as commercial banks.

Although microfinance institutions provide numerous financial services, microcredit is the main product of microfinance. Becker (2010, 47-48) points out that, in emerging credit markets, there are three main credit types provided by microfinance institutions. The first is consumption credit, intended to finance the purchase of non-durable goods. The second type is productive credit (microcredit), which helps clients develop or start a new business, and generally with little collateral, or none at all. And the third is corporate credit, the most common type provided to small and medium businesses, always with collateral.

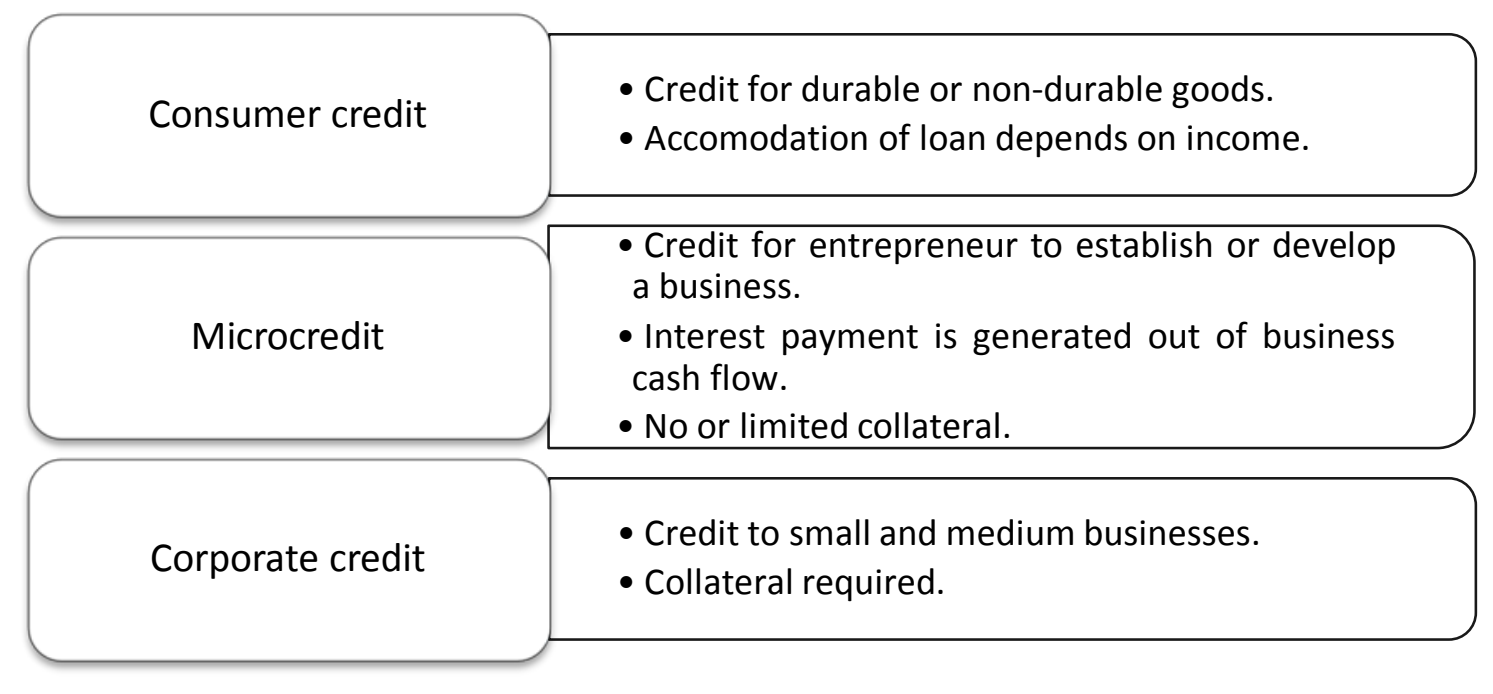

Figure 2.1: Segmentation of credit categories. Source: Becker 2010.

In 2004, the Consultative Group to Assist the Poor (CGAP) constructed a list of the key principles of microfinance (CGAP 2004), shown in Box 2.1. 
Box 2.1: Key Principles of Microfinance

1. The poor need a variety of financial services, not just loans. Credit schemes are useful for helping poor businesses generate more income. However, these businesses still need other financial services, such as savings, cash transfers, and insurance.

2. Microfinance is a powerful instrument against poverty. Through microfinance, the poor have possibilities to increase their incomes, build assets, improve their standard of living, and reduce their vulnerability to external factors.

3. Microfinance means building financial systems that serve the poor. To reach the goals of microfinance, integration within the financial sector is required.

4. Financial sustainability is necessary to reach significant numbers of poor people. The ability of microfinance institutions to cover operational costs enables large numbers of the poor to access their services. Sustainability therefore results in further provision of services, as well as reduced transaction costs, better products and services, and finding new ways of reaching those in need of their services.

5. Microfinance is about building permanent local financial institutions. Mobilizing and recycling domestic savings, extending credit, and providing a range of services, all of which may enable institutions to operate on a permanent basis while dependency on donors and the government diminishes and local institutions and markets mature.

6. Microcredit is not always the answer. Small grants, infrastructure improvement, employment and training programs, and other non-financial services also have the potential to combat poverty.

7. Interest rate ceilings can damage poor people's access to financial services. Serving many small loans is more costly than a few large loans. Interest rate ceilings enable microfinance institutions to cover their operational costs, but may negatively affect the ability of the poor to access financial services.

8. The government's role is as an enabler, not as a direct provider of financial services. Governmental policies on enhancing microfinance institutions and supporting their financial services for the poor are more meaningful than providing their own lending systems.

9. Donor subsidies should complement, not compete with private sector capital. Donors should use grants, loans, and equity instruments only temporarily to build institutional capacity and develop supporting infrastructure, as well as support experimental services and products. Longer-term donor subsidies may be used to reach remote or sparsely-populated areas.

10. The lack of institutional and human capacity is the key constraint. Microfinance combines banking with social goals, and capacity needs to be built at all levels. Most investments should focus on capacity building.

11. The importance of financial and outreach transparency. Bank supervisors and regulators, donors, investors, and clients of microfinance institutions require complete and comprehensive information on their financial and social performance. 


\subsection{Conventional and Islamic Microfinance}

Microfinance institutions (MFIs) often start as non-profit enterprises with the social goal of helping the poorest to access financial services (Maier and Pischke 2006, 12-13). Their establishment is made possible by grants and donations from private donors and development agencies, and as they develop, maintaining their provision of services to poor clients becomes a main imperative. Independence from initial subsidies, through the ability to generate their own profits, becomes essential to sustainability. Amongst conventional MFIs, this is achieved through the use of interest, while Islamic MFIs, prevented by Islamic law from using interest, implement profit-sharing schemes and accept public donations.

Grameen Bank, considered a pioneer amongst microfinance institutions, has successfully provided financial services to the peoples of Bangladesh for nearly forty years, much of them credit schemes through group lending. It also partakes in a number of social programs, such as capacity building and programs empowering women and beggars. However, this institution is known to use interest-based schemes (Meisami, Manzur, and Roayaee 2011). Islamic MFIs have their own inherent characteristics that help mitigate the financial risks faced by conventional MFIs (Ahmed 2002). Some principle differences between conventional and Islamic microfinance is presented in Table 2.1 .

Table 2.1: Differences between conventional and Islamic MFIs.

\begin{tabular}{|c|c|c|}
\hline Item & Conventional MFI & Islamic MFI \\
\hline $\begin{array}{lll}\text { Liabilities } & \text { (sources } & \text { of } \\
\text { funds) } & & \end{array}$ & $\begin{array}{l}\text { External funds, clients' } \\
\text { savings }\end{array}$ & $\begin{array}{l}\text { External funds, clients' savings, } \\
\text { charity-based sources }\end{array}$ \\
\hline Assets (mode of financing) & Interest-based & Islamic law-based \\
\hline Financing the poorest & Poorest are left out & $\begin{array}{l}\text { Poorest can be reached through } \\
\text { integrating charity-based funds } \\
\text { with microfinance }\end{array}$ \\
\hline Funds transfer & Cash transferred & Goods transferred \\
\hline $\begin{array}{l}\text { Deduction at inception of } \\
\text { contract }\end{array}$ & $\begin{array}{l}\text { Part of the funds deducted } \\
\text { at inception }\end{array}$ & No deduction at inception \\
\hline Target group & Women & Family \\
\hline $\begin{array}{l}\text { Liability of the loan (when } \\
\text { given to women) }\end{array}$ & Recipient & Recipient and spouse \\
\hline Employee motivations & Monetary & Monetary and religious \\
\hline Dealing with default & $\begin{array}{l}\text { Group/center pressure and } \\
\text { threats }\end{array}$ & $\begin{array}{l}\text { Group/center/spouse/guarantee } \\
\text { and Islamic ethics }\end{array}$ \\
\hline $\begin{array}{l}\text { Social } \\
\text { program }\end{array}$ & $\begin{array}{l}\text { Secular (or non-Islamic) } \\
\text { behavior, ethical, and } \\
\text { social development }\end{array}$ & $\begin{array}{l}\text { Religious (includes behavior, } \\
\text { ethics, and social) }\end{array}$ \\
\hline
\end{tabular}

Source: Ahmed 2002. 
Additionally, Islamic microfinance is able to exploit charity funds, such as zakat, infaq, and shadaqah, as their fund sources for delivering financing, whereas conventional microfinance does not have access to these capital sources. However, conventional microfinance can use interest as a method of increasing income, while Islamic microfinance is instead required to provide other schemes that still remain compliant with Islamic laws (Rahman 2007).

The need to employ Islamic principles in Islamic finance, such as avoiding riba, gharar, jahl, darar, and other unfair business practices, does not mean Islamic MFIs have limited financial products. Islamic microfinance employs several methods of fund mobilization and financing, and uses a monitoring system for managing risk (Obaidullah and Khan 2008, 18). Detailed characteristics and operational experiences of both institution types are described below.

\subsubsection{CONVENTIONAL MICROFINANCE}

At the start of the 1970s, the common perception of microfinance was that financial institutions serving the poor in low-income countries required massive subsidies. As a result, the task of providing financial access to low-income households was shouldered by state-run banks, who were costly and largely inefficient (Watkins and Hicks 2009). At the turn of the decade, however, the belief that serving the poor was inherently overly-expensive was refuted by the successes of microlenders in Africa, Asia, and Latin America. In Indonesia, the first country to provide large-scale commercial microfinance, the mid-1980s were met with significant change in the financial sector (Robinson 2002). In 1983, the government deregulated interest rates on most bank loans and savings accounts, and Badan Kredit Desa (BKD), village-owned rural banks first established in 1895 and run by the state-owned Bank Rakyat Indonesia (BRI), were transformed from government-subsidized rural credit agents into commercial microfinance intermediaries. A year later, fortunes of BRI's loss-making unit desa system reversed, becoming what is now the world's largest nationwide commercial microbanking system. Unlike Grameen Bank, with its group lending mechanism, BRI today requires borrowers to provide collateral, consequently preventing the poorest from being able to access their services (Morduch 1999). Microfinance received a great amount of attention in the wake of Grameen Bank's emergence, particularly relating to its focus on poverty alleviation, collateral-free lending, and low-interest microloan programs (Yunus 2007, 68). Its financial services have been closely tied to the innovative idea of group lending with joint liability (Armendariz de Aghion and Morduch 2000). As Armendariz de Aghion and Morduch (2005, 119) explain, group lending, the most celebrated innovation in microfinance, is an example of how unconventional contracts can succeed where "tried-and-true" banking practices have failed, and thus serves as but one element that differentiates microfinance 
from conventional banking. Group lending with join responsibility can additionally mitigate adverse selection amongst microfinance institutions. In the case of Grameen Bank, progressive lending refers to the practice of providing larger loans to groups and individuals who have a good borrowing record. The institution's innovations include weekly or monthly installment repayment schedules, public repayments, and targeting specific segments of society. More flexible collateral schemes have been used by other microlenders.

Ledgerwood (1999, 17-20) lists a number of financial sector policies and their relation to microfinance:

1. Interest rate policies. Intended to maintain institutional efficiency and competitiveness, which may be undermined by policy restrictions. In order to be able to cover their operational costs, MFIs need to price their loan products accordingly.

2. Government-mandated credit allocations, in which some governments mandate that formal institutions allocate a certain percentage of their portfolio or assets to the informal or poorer segments of society. While this may benefit some MFIs, sectoral mandates "almost always distort the market."

3. Legal enforcement of contractual obligations. Well-defined property rights and contract law help to minimize transaction costs, thus freeing up resources. Harsher laws, allowing institutions to formally charge borrowers in the event of a default, which may lead to substantial fines or even imprisonment, also serve as effective deterrents against defaulting, protecting institutions.

Some decision-makers and stakeholders point out that poor borrowers should be protected from high interest rates. Roberts (2013) reported that, in 2009, microfinance institutions that “displayed stronger profit orientations tended to charge higher effective rates while operating at higher cost”, noting as well that they never seem to produce the expected benefits for clients. Ledgerwood and White (2006, 24) similarly suggest that MFIs often charge high interest rates as a result of the need to generate enough revenue to cover operational costs. Furthermore, operational costs (sometimes referred to as administration costs) are usually the largest component (10-25\% of the average loan portfolio) of the interest rate charged by MFIs to their clients (Goldberg and Palladini 2010, 41). Most MFIs charge a nominal interest rate of 20\%. In order to maintain its financial sustainability, Grameen Bank charges 32\% (Morduch 1999). An empirical study in Nigeria by Mohammed and Hasan (2008) revealed that microfinance institutions charged their clients as high as $100 \%$ in their credit schemes, while savings schemes 
had interest rates as low as 5\%. While independence is preferable, some MFIs require extra funds to cover their operational costs, which come in the form of government assistance, the international political community, or re-investment (Sandberg 2012).

Reducing poverty, empowering the marginalized, creating employment, and creating and developing businesses are the aims of MFIs (Ledgerwood 1999, 34). However, the extremely poor usually need direct support, in the form of food, shelter, medicine, training, and employment, which are generally not the concerns of conventional microfinance. Government subsidies, donor assistance, and charity funds are instead more appropriate for these services. Government intervention, such as allocating national economic revenue, increasing international trade, and foreign investment in local institutions, as well as some social factors, is critical to the success of poverty alleviation programs (Daly and Fane 2002; Jellinek 1992). In addition, integrating all forms of microfinance into a country's financial system gives a wide range of people-and particularly the poor-opportunities to access loans and protect their savings (CGAP 2006, 4). Conventional microfinance can make positive contributions to empowering the extremely poor by helping them generate income on their own terms (Hulme and Arun 2009, 46). However, a study by Navajas et al. (2000) in La Paz, Bolivia, showed that MFIs tended to offer their services to people near poverty line, only, not to the poorest, who are much less credit worthy and more vulnerable.

\subsubsection{ISLAMIC MICROFINANCE}

Some studies reveal the positive roles of religious beliefs and spirituality on the development process (De Kadt 2009; Lunn 2009; Ter Haar and Ellis 2006). Religion can support the economic welfare of the societies in which it is found, particularly when it is involved in providing financial services. Fernando $(2007,32)$ points out that access to finance is a central issue in development, in terms of growth, poverty, social development, and equity. Thus, bridging religious institutions and the financial sector is important to support human development (Mirghani et al. 2011). Mersland, D’espallier, and Supphellen (2013) measured the performance differences between Christian and secular microfinance institutions, specifically in their economic development contributions to society. Their findings revealed that Christian MFIs’ performance indicators were based on social, rather an economic, factors.

Conventional MFIs have low penetration in low-income Muslim communities because these communities would prefer to adopt Islamic law-compliant finance (Wilson 2007). As a result, in recent decades, Islamic microfinance has shown promise as institutions see an increase in market 
demand and greater participation in international finance. These institutions are based on Islamic principles, such as the prohibition of interest-based lending, conducting unfair or exploitative economic activities, giving or receiving bribes, or determining return percentages on financial transactions (Karim et al. 2008; Seibel 2008). Promoting Islamic microfinance according to Seibel (2008) can be done through encouraging Islamic commercial banks to create units for Islamic microfinance, and reappraising Islamic rural banks and cooperatives on their challenges and opportunities.

Islamic finance involves providing financial services to clients using Islamic principles, such as brotherhood, solidarity, and partnership. Furthermore, institutions and clients usually share the benefits and risks of their transactions in accordance with the contributions they support (Seibel and Wahyu 2006). According to Gait and Andrew (2009), the main products of the Islamic financial system are mudarabah (partial equity partnership), musharakah (full equity partnership), murabaha (financing for purchasing goods), bai bi tsaman 'ajil (deferred payments on products), bai salam (advance sale contracts), istisna (manufacturing contract system), ijarah (lease financing), and qard al hasan (credit without interest). While targeting the poor is the main objective of microfinance, reaching the poorest of the poor is associated with higher risks, and therefore presents a problem for some institutions. Islamic microfinance, with its access to social funds such as zakat, infaq, and shadaqah helps it reach the poorest (Mirgani et al. 2011; Kaleem and Saima 2010). These charity funds are generally distributed by Islamic MFIs in the form of qard al hasan schemes. Through this social scheme, Islamic MFIs increase the potential of not just reaching the poorest, but helping them become credit-worthy and minimizing the unequal distribution of wealth within society (Smolo and Ghafar 2011; Widiyanto, Mutamimah, and Hendar 2011).

In Indonesia, Islamic MFIs are categorized into three types: Islamic microfinance divisions of Islamic banks, Islamic rural banks (BPRS), and Islamic financial cooperatives called baitul maal wat tamwil (BMT). As BMTs' operations are supported by Islamic banks, BPRS, and big Islamic organizations such as Nahdlatul Ulama (NU) and Muhammadiyah, they have a network of more than two thousand institutions. Millions of the poor and poorest are able to access the financial services of these microfinancial institutions (Obaidullah 2008, 57). In addition, Center for Micro Enterprise Incubation (Pinbuk) reported that around 3609 BMTs provide financial services, with a focus on the poor in Indonesia. 


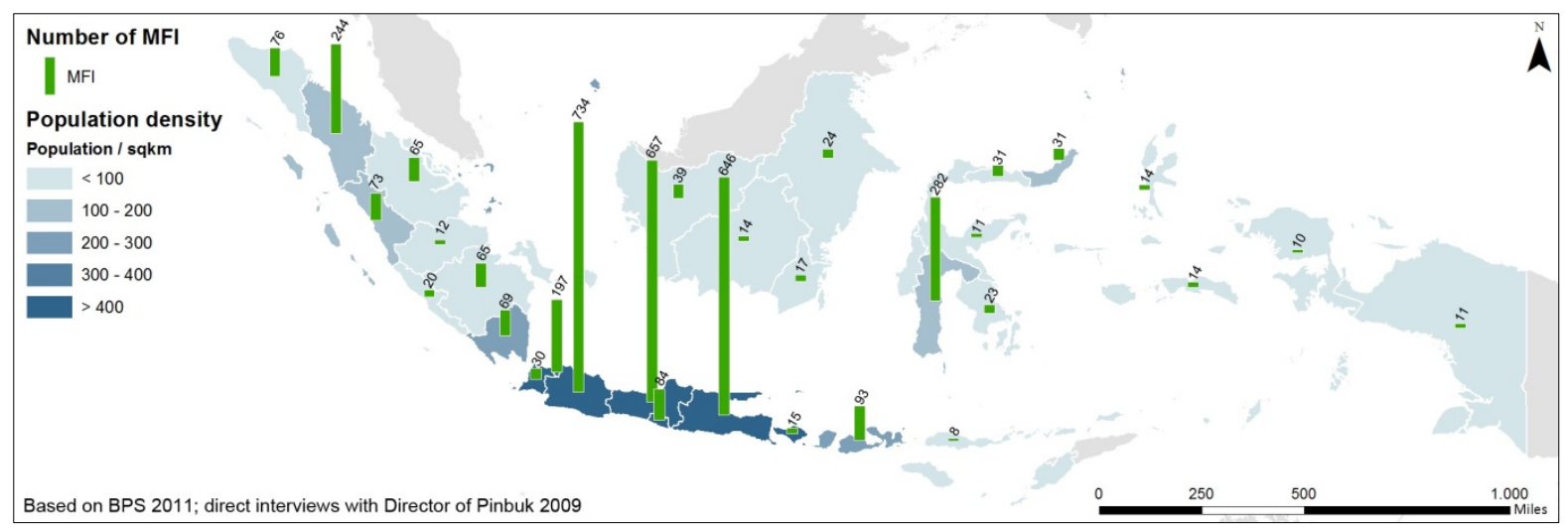

Figure 2.2: Geographical distribution of BMTs in Indonesia. Sources: direct interviews with the Director of Pinbuk.

Ahlin, Lin, and Maio (2011) note that the country environment - that is, the macroeconomic and macro-institutional environment in which an MFI is situated-should be factored into MFI evaluation, as this has a significant impact on the success of an institution in terms of its sustainability and extensive and intensive growth. Islamic MFIs in Indonesia, as Obaidullah (2008, 58) states, have performed well, particularly in response to econonic crises. Since the institutions are unregulated and largely independent (based on cooperative management), they have a robust financial system avoidant of the systemic risks that arise from interdepence. During the crisis period of 1997-1998, the independence of Islamic MFIs allowed them to weather Indonesia's unstable financial and political environment, and escape the widespread collapse faced by institutions that were based on interdepence between government and institution. All independent institutions in this case, and specifically those employing profitsharing schemes, were unaffected by the macroeconomic climate and continued to operate without hindrance. Furthermore, Syariah Rural Credit Bank (BPRS), a formal Islamic microfinance instution under regulation of Bank Indonesia, has also shown positive development from year-to-year (Figure 2.3). BPRS can be accessed by a wide range of people, since it provides financial services to rural areas, as opposed to solely urban (Bank Indonesia 2011, 7). 


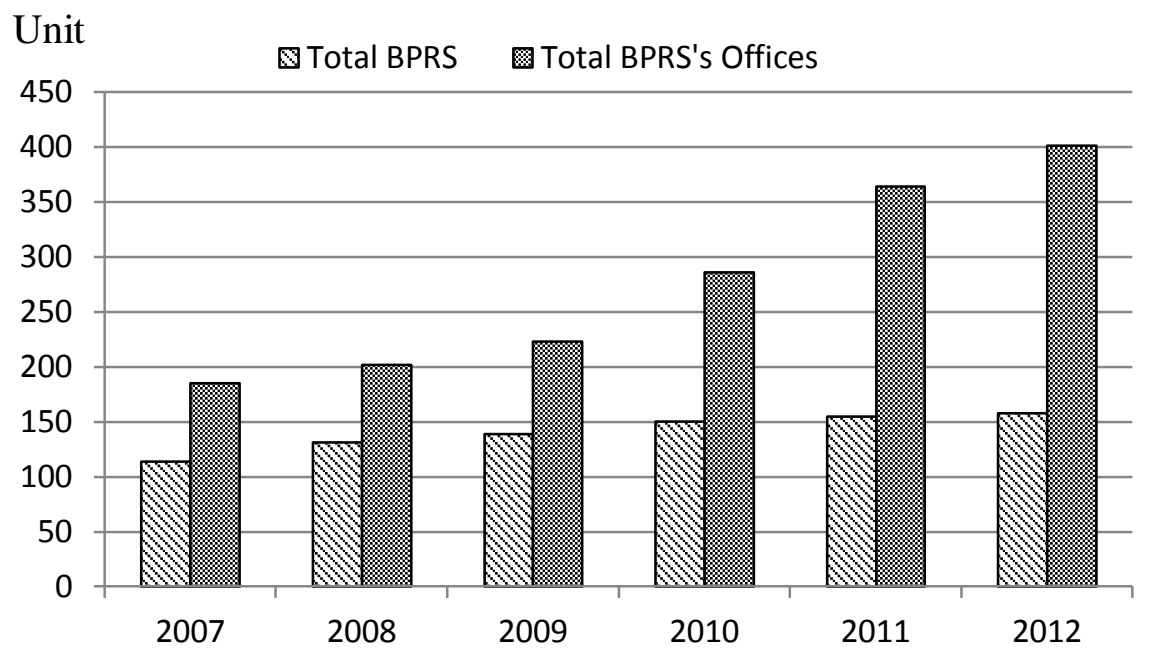

Figure 2.3: Number of BPRS institutions and offices. Sources: Indonesian Banking Statistics; Bank Indonesia.

\subsection{Asymmetric Information}

An efficient monitoring system is necessary if a financial institution is to maximize the repayment rate of its clients and ensure that its credit schemes are well-managed. The concept of asymmetric information was introduced by Akerlof (1970) to explain an imbalance of information between buyer and seller. In his used car market illustration, buyers were unable to ascertain whether a used car was a "cherry" (a good car) or a "lemon" (a defective car). Thus, with the best estimation being that the car was of average quality, the buyer would offer an average amount for what may be cherry or a lemon. This would benefit the seller of a lemon, but harm the seller of a cherry. Consequently, the number of sellers of good cars, who refuse to sell their car for less than it is worth, would reduce, and the market as a whole would be negatively impacted. While asymmetric information is important in theory, in practice, it is difficult to identify (Karlan and Zinman 2009). In a study on estimating the presence and importance of adverse selection and moral hazard, Karlan and Zinman found stronger evidence of moral hazard than adverse selection, with $13 \%$ to $21 \%$ of defaults being caused by moral hazard. Hence, asymmetric information is one factor behind the occurrence of credit constraints, particularly in providing loans to borrowers with high risk. According to Dusuki (2008), enhancing capacity building through social intermediation and adopting a group lending mechanism positively affects the transfer of information between institution and client, and thus minimizes adverse selection and moral hazards.

Using a group lending system to minimize the possibility of asymmetric information is an important component in the success of Grameen Bank, and signing financial transactions as 
groups may help increase effective collateral and induce peer-monitoring (Stiglitz 1990). Through the establishment of group lending mechanisms and weekly installment schemes, conventional MFIs have successfully mitigated credit risks. As a result, Ahmed (2007) suggests that Islamic MFIs should take these successes into consideration when combating their own financing problems.

However, according to Laffont (2003), while group lending may be a powerful tool for institutions, this mechanism of subtle discrimination it not optimal until collusive behavior between borrowers is allowed. Van Tassel (1999), meanwhile, shows that one method of overcoming inadequate information, particularly when collateral or credit history are unavailable, may be using joint liability as a means of screening agent types by "inducing endogenous group formation and self-selection among the borrowers.” Besley and Coate (1995) found that group lending affected repayment rates both positively and negatively. The positive effect was that successful members of the group had incentives to repay the loans of other, less successful, group members, while the negative effect occurred when the group as a whole would default, in spite of some members' successes and ability to repay. Group lending harnessing social collateral, however, can serve to mitigate this negative effect. Meanwhile, in an examination of the social cost of repayment pressure in group lending, Montgomery (1996) argues that the poor can be protected from socially damaging lending practices based on peer pressure, through the use of flexible repayment schedules, savings facilities, and short-term, high-interest consumption loans.

\subsubsection{ADVERSE SELECTION AND MORAL HAZARD}

The problem of adverse selection is usually encountered by financial institutions when they cannot distinguish between risky and safe borrowers. Inadequate information limits institutions in charging different interest rates to different types of borrowers (Armendariz de Aghion and Morduch 2005, 88).

If financial institutions have difficulties in monitoring their clients' businesses, the occurrence of moral hazard is a possibility. Bester (1987) points out that some lenders mitigate moral hazard and adverse selection through the use of collateral as a self-selection and incentive mechanism. Additionally, credit rationing occurs when the collateral of borrowers is of low value, at which point they will be charged the maximum amount of collateral. These schemes, however, may affect the reach of institutions, as a lack of sufficient collateral is a frequent problem amongst the poor. 
In an empirical study by Jackson and Schneider (2011) examining the role of social networks in aligning incentives in settings with incomplete contracts, taxi drivers who were leased their taxis had worse driving outcomes than those who owned them. However, drivers who leased from members of the same country-of-birth exhibited significantly reduced effects of moral hazard. The authors found social cohesion to give incentives that resulted in positive selection.

\subsubsection{MONITORING IN ISLAMIC MFIs}

As a part of their financial services, Islamic financial institutions generally establish monitoring systems to ensure that the prospective transaction is appropriate and meets the ethical and religious standards of Islamic law. Islamic financial institutions usually use partnership schemes with their clients, sharing both the profits and risks with them. Thus, both the institutions and their clients build good communication and intensive interaction, which are rarely found in conventional financial arrangements (Barden 2010). According to Hasan (1995), Islamic ethics have the possibility to mitigate the moral hazards and adverse selection of economic actors.

Islamic microfinance uses personal guarantors, group savings accounts, and community recommendations to ensure repayment (Khan 2008, 28). All of these aspects have worked well from the perspective of Islamic microfinance institutions, and contributed positively to repayment levels.

\subsection{Assessing the Role of Microfinance on Poverty Alleviation}

In looking at microfinance's potential, Morduch (1999) described how, although truly destitute households needed more than finance-based programs, microfinance had provided promise for millions of households, and inspired even critics with its success. While most commercial banks do not offer loans to the poor because of the risk involved, such as high costs for small transactions, perceived low profitability, and inability of the poor to provide collateral (Asian Development Bank 2000, 9), microfinance institutions provide financial services that are specifically directed to low-income people, without requiring collateral in many cases. Microfinance is a powerful poverty alleviation tool, enabling the poor to increase their economic security, build assets and reduce vulnerability, create demand for goods and services that would otherwise receive little attention, such as nutrition, health care, and education, and stimulate their local economy (Bansal 2012; Brandsma and Deena 2004, 7). The concept of microfinance was specifically designed to allow the poor to be competitive in a global market economy. By providing financial services to poor entrepreneurs, MFIs have been a successful tool for growing businesses (Fairbourne 2006, 19). 
Enacting laws that regulate the provision of microfinance services to low-income people is a part of many countries' poverty reduction strategies (Hulme 2000). There are significant differences, in terms of increasing income and economic status, between the people who join MFIs and those who do not. According to Jegede, Kehinde, and Akinlabi (2011), MFI clients tended to have better welfare than non-clients. However, although at a lower effect, microfinance does impact non-clients' economic welfare, as well. According to Khandker (2005), along with improving the local economy, MFIs affected the household consumption of both MFI clients and non-clients. An attempt to quantify the impact of the most important credit programs of Grameen Bank, Bangladesh Rural Advancement Committee (BRAC), and Bangladesh Rural Development Board's (BRDB) RD-12 project in Bangladesh by Khandker, Samad, and Khan (1998) revealed that the programs positively impacted the income, production, and employment of workers in rural non-farm sectors. Meanwhile, in Pakistan, Montgomery and Weiss (2011) found evidence of microfinance's effect in reducing poverty, empowering women, and improving children's health, as well as its contribution to the UN's millennium development goal of halving the world's poverty rate by 2015. MFIs, through their microcredit services, effectively impact the incomes and assets of their clients (Rahman, Rafiq, and Momen 2009). In cases in Malaysia, Bolivia, and Bangladesh, microfinance was found to be an effective tool for increasing income, assets, and spending (Hossain 2012; Chana and Mazanah 2011; Mosley 2001). Another study by Khalily (2004) in Bangladesh found positive impacts to poverty, income change, consumption expenditures, net worth, asset accumulation, and education. Mawa (2008) further noted that while some problems existed, microfinance was able to make meaningful contributions to poverty alleviation, and concluded that institutions need to look more seriously at the diversified needs of the poor and target the extremely poor.

Assessing the microfinance initiative of the post-Tsunami sustainable coastal livelihoods program in Thailand, Crawford (2007) found that the establishment of MFIs and their loan instruments helped rural coastal people recover from natural disasters through the creation of new businesses. MFIs consequently affected the welfare of the people within the region, whilst reducing the prevalence of money lenders. Al-Mamun et al. (2012), examining whether Amanah Ikhtiar Malaysia improved the incomes of poor households, found the program to be effective at both increasing household income and reducing poverty.

A study by Afrane (2002) in Ghana and South Africa revealed that microfinance played a significant role in improving the business income, life-enhancing facilities, and female empowerment of clients. Morris and Barnes (2004), in a study in Uganda, found several positive 
impacts to microfinance institutions, themselves, such as increasing products and services, improving enterprise markets, reducing costs of inventory purchases, and increasing sale volumes, in addition to a number of positive effects on the household level, such as allowing people to start new businesses, increase the amount spent on durable assets and agricultural land, and the amount of household income earned from crops. In northern Ethiopia, Berhane and Garderbroek (2010) found microfinance to increase household consumption and housing improvements. Meanwhile, in Zambia, Copestake, Bhalotra, and Johnson (2001) found MFIs to have significantly affected the average growth of businesses' profits and clients' household incomes. Their findings showed that microfinance both significantly increased the annual per capita household consumption of clients and improved their housing.

Despite the numerous cases of microfinance having a positive effect on poverty alleviation, giving credit to the poor is not always an effective strategy to combat poverty. Coleman (1999) found that in Northeast Thailand, group lending-based microfinance had an insignificant impact on physical assets, savings, production, sales, productive expenses, and labor time, as well as most measures of expenditure on education and health care. One reason, as the author noted, may have been that loans were too small to be used for productive investment, and so were instead primarily consumption loans. Members consequently failed to generate any new income and repay their loans. Adams and Pischke (1992), in a study on micro enterprise credit programs, concluded that debt for the poor is not an effective tool to improve their economic condition. Takahashi, Higashikata, and Tsukada (2010) conducted an empirical study in Indonesia on the impact of microcredit schemes on the welfare of the poor. According to their findings, microcredit had a statistically insignificant effect on various household outcomes in general, with the exceptions being sales of non-farm enterprises for the non-poor and schooling expenditures. In Bangladesh, Amin, Rai, and Topa (2003) found that MFIs were successful in reaching the poor, but less able to reach the vulnerable. Thus, other instruments, such as providing training, increasing skills, and directly transferring cash, might be better strategies for reaching the poor, and poorest, in particular. An empirical study in Indonesia by Deloach and Lamanna (2011) also found that MFIs affect children's health by giving women the opportunity to increase their bargaining power and social capital.

Although they are likely not able to completely serve the poorest because of the perceptions of overly high risk, Islamic MFIs do offer some financial schemes-such qard al hasan-to the poorest entrepreneurs (Seibel and Wahyu 2006). An empirical study on access to Islamic microfinance programs in Bangladesh by Rahman (2010) revealed that clients significantly 
increased their household income, productivity of crops and livestock, expenditures, and employment. The author concluded that Islamic micro-investment may encourage more ethical and economically desirable behavior that would lead to poverty alleviation. In addition, according to Sirageldin (2000), Islamic ethics plays a positive role in supporting poverty alleviation programs based on promoting economic growth with productive equity. Obaidullah and Khan $(2008,17)$ state that Islamic MFIs have a more comprehensive approach to poverty alleviation than conventional MFIs, since they are able to reach the poorest of the poor and provide them with access to financial services. Additionally, Sugema, Bakhtiar, and Effendi (2010) suggest that the performance of profit and loss sharing schemes, one of the staples of Islamic microfinance, can be further improved through the establishment of a risk-pooling mechanism that absorbs all the risk encountered by both institution and client, enabling greater fund distribution and reducing income disparity.

\subsection{Assessing the Role of Microfinance on Environmental Awareness}

Most MFI clients are poor and derive their income from natural resources. Their daily activities directly affect the condition of their surrounding environment. A recent trend in microfinance has been for institutions to allocate loans to environmentally-friendly businesses. This practice is known as green microfinance (Rouf 2012a), in which, for example, institutions improve sanitation and environmental health, and encourage clients to reduce harmful waste disposal, partake in more efficient and environmentally-friendly agricultural practices, and reduce population pressure on the environment. In North America, demand for environmentally-friendly products and services, as well as green financial products, has been rising, albeit at a slower pace than in Europe. In general, these products are intended to reduce negative impacts on the environment and provide environmental assistance (UNEP 2007, 14).

Rouf (2012b) compared and contrasted Grameen Bank and Grameen Shokti from Bangladesh with Canada's Alterna Savings in terms of their microcredit and renewable energy programs for green development. He found that in both countries, microcredit had a positive effect on sustainable development, although he notes that the respective countries need more than MFIs to play a role in financing and supporting green micro enterprises. Environmental organizations and NGOs can provide training on issues such as recycling waste and adopting renewable energy, and provide support and funding to green MFIs. Through this participatory process, MFIs' contributions are enhanced and people-centered environmentally-sustainable development is able to take place. According to McKernan (2002), in order to achieve its goals-particularly those of 
poverty alleviation-Grameen Bank provides non-credit services in addition to its credit services, such as vocational training, the provision of health and other information, and information-sharing and monitoring amongst members, all of which were shown to positively affect clients' self-employment-derived profits. Jha and Bawa (2007), in their analysis of ecodevelopment in India, which revealed that skills reduce environmental pressure, argue that MFIs need to develop knowledge-intensive skills in their clients, as well as increase involvement in their business operations. Rajendran and Raya (2010), meanwhile, found microfinance and Self Help Groups (SHG) in India to be effective at creating environmental awareness and ensuring environmental sustainability.

\subsection{Links between Microfinance, Poverty, and the Environment}

Microfinance plays an essential role in accelerating sustainable development in developing countries, by providing soft loans to develop and maintain clients' micro enterprises. It can also increase overall wealth, since, as Brook, Hillyer, and Bhuvaneshwari (2008) point out, the poor and very poor are more actively involved in microfinance than members of other wealth classes. Ecological resources, whether aquatic or terrestrial, have contributed to human welfare and development. However, in the absence of adequate policies, economic development negatively affects the use of natural resources, and consequently contributes to environmental degradation. According to Dasgupta and Mäler (2003, 9), there is a causal link between poverty and environmental damage. Hence, poverty reduction programs will be more effective when they are connected to environmental management strategies (World Bank 2008).

Through the credit schemes of microfinance institutions, micro entrepreneurs are to develop their businesses, increasing their income and re-investment. However, increasing the size of a resource-based business may affect the environment, when resource use intensifies, especially when the use is already harmful, such as chemical-intensive agriculture, the frequent slaughter of livestock, or unsustainable fishing (Anderson, Locker, and Nugent 2002). Scott (2000) notes that there is a potential conflict between the development objective of employment creation and the objective of environmental reduction and sustainability, where, although the effect of small businesses may not be recognized on the national level (Hillary 2004), there is the need to recognize their aggregate contribution to environmental degradation. Small and medium-sized enterprises (SME) have consequently come under increasing pressure, from government, trade associations, and customers, to address their impact on the environment (Friedman, Miles, and Adams 2000), especially when there are competitive and financial, rather than purely ethical, reasons for adopting environmentally-friendly practices (Simpson, Taylor, and Barker 2004). 
Several authors have pointed out that more than a voluntary approach is required to encourage wide-scale SME adoption of environmental initiatives. Williamson and Lynch-Wood (2001) argue that a paradigm shift is required. Stakeholder perceptions within SMEs should be changed, and SMEs should formally acknowledge their roles and responsibilities. Being provided with performance-based motivations may be the most effective method, which may also require the assistance of external organizations. The most effective way to simultaneously achieve poverty alleviation and environmental conservation is through increasing knowledge of what drives a particular business and seeking to the best way to maximize its profits without increasing its dependence on environmentally unsustainable behavior. Knowledge-based poverty reduction programs contribute to reducing the degradation of natural resources (Reardon and Vosti 1995). For example, knowledge of soil conditions can lead to better agricultural yields, not only reducing poverty, but encouraging further and greater awareness.

Because MFIs provide financial services based on relationships and business partnerships, they have an opportunity to mitigate the environmental damage that occurs as a result of their clients' activities or in their surrounding environment, particularly if their incomes are reliant on natural resources. Cavendish (2000) reports that environmental resources in developing countries contribute to around $40 \%$ of average rural incomes. Microfinance can reach the poor in as far as remote, isolated areas and enable them to be aware of their economic obstacles in a wide context. In a number of countries, microfinance institutions, input suppliers, produce buyers, and agroprocessors have experimented with innovative credit delivery methods that involve a diversified client base, in both location and sector (CGAP 2006, 28).

The recent emergence of green microfinance, which Rouf (2012b) defines as an attempt to balance profit generation with the ecological aspects of business, resources, environment, and society, is considered to have an effect on both eradicating poverty and increasing environmental sustainability. Institutions partaking in green microfinance focus on allocating soft loans to support sustainable green and social development, create green jobs, and protect the environment from various damages. According to Jha and Bawa (2007), In order to achieve desirable economic and environmental outcomes, there are several requirements in green microfinance: stakeholder involvement, wide MFI establishment that enables networking between institutions, diversification of knowledge-intensive skills, and the opening of protected areas for sustainable enterprises. 
Crawford (2007), in a study in Thailand, found several impacts of microfinance activities:

1. Restarting and diversifying borrower livelihoods. Of the businesses in the research site, 4\% were classified as new, while $96 \%$ already existed, or had expanded or restarted.

2. Promoting sustainable natural resource use, through offering credit schemes for alternative livelihoods, such as green mussel and catfish aquaculture, ginger and rubber production, goat and cattle ranching, trading, and processing. These micro enterprises enable the community to generate income from a variety of economic activities, thus reducing overexploitation of a single resource.

3. Reducing dependence on money lenders, who in this case would purchase clients' goods at a reduced price in exchange for loans or charge high interest rates. This could be done through providing social services, having emergency funds in times of need, or making donations to local community welfare initiatives, as opposed to merely providing credit.

4. The multiple donor effect, which is having many donors to provide funds without repayment expectations or charging fees. This led in some cases to poor attitudes regarding repayment, and thus low repayment rates. Some villages combated this by restricting community members to receiving funds from no more than one bank, although unconfirmed rumors of individuals receiving multiple loans were common.

A study by Zeller et al. (2000) in Madagascar revealed that access to microfinance positively affected rice yields in lowland areas and soil fertility soil in upland areas, concluding that microfinance beneficially affected agriculture production, poverty, and the natural resources of clients. Microfinance institutions have great opportunities to promote environmental awareness amongst their clients, through the use of schemes geared towards eco-friendly business practices (Wenner, Wright, and Lal 2004). And while, in general, theoretical and empirical findings have shown that microfinance institutions have been able to balance institutional sustainability with a positive influence on environmental awareness and poverty alleviation, room for improvement still exists. Archer (2002) observed that only $10 \%$ of a sample of forty MFIs incorporated green microfinance into the structure of their financial products, with his analysis uncovering a "potential disconnect between the mission of most MFI lenders and the tactical implementation of their microfinance programs”, suggesting that instead of microfinance helping the poor, they, along with the planet, may be at risk of being further harmed. Parvin and Shaw (2013) looked at the perception of MFI support for the disaster risk reduction, response, and recovery process, and found that over half of the clients of MFIs saw no change in relation to risk reduction, and income and occupation aspects, while only a minority saw less damage as a result of being a 
member of an MFI. In their multiyear study on the short- and long-term ecological effects of shade trees in coffee and cacao agroforestry, Tscharntke et al. (2011) argue that biodiversity conservation measures aiming to promote sustainable cultivation require economic incentives to be successful. Such a project would also require a clear organizational structure, to mitigate corruption, as well as the involvement of community members in the management process (Seeberg-Elverfeldt, Schwarze, and Faust 2010). Along with the integration of communities and their members into conservation policies, increasing the environmental awareness of the institutions that support these communities is itself vital. 


\section{Circle of poverty and environmental degradation}

Poverty: Low purchasing power, poor health, low education level and lack of access to information, and low empowerment.

Environment: High pollution rate, environmental degradation, harmful waste disposal, little environmental regulation compliance.

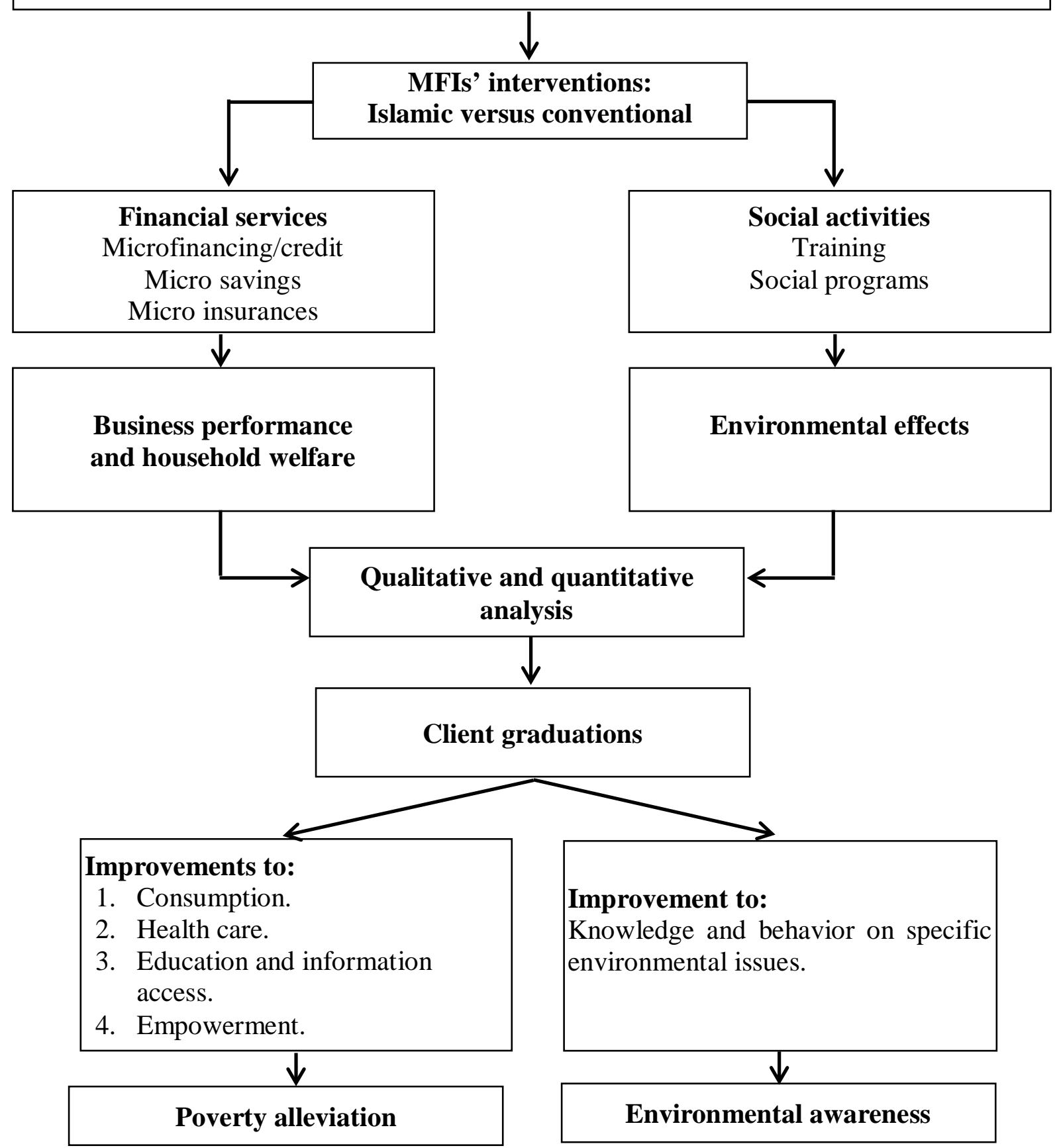

Figure 2.4: Conceptual framework of this study. 


\section{Research Methods}

\subsection{Research Preparation and Permission}

\subsubsection{Preparation Stage}

Research preparation was conducted before departure to Indonesia in the beginning of February, 2011. Directors of Islamic microfinance institutions, local politicians, and microfinance experts were contacted to ensure that conducting field research in the intended research area was possible, and that the research area would be compatible with our research designs. In discussing our research with the various experts, we were made aware of any negative attitudes on the part of any Islamic microfinance officials, key informants, or local people, informed of the most suitable subdistricts in Pasuruan Regency, and provided with contact lists and the necessary documents to reach these areas. After the necessary preparations were made, information and secondary data were collected in Jakarta and Bogor, Indonesia. We then traveled to East Java to do a preliminary investigation of each research site and determine the best sample sizes with the aid of Islamic microfinance directors and local government officers, before conducting test questionnaires and preliminary interviews in the research area.

\subsubsection{Obtaining Research Permissions}

As collecting research data without permits may have presented problems with authority offices, we obtained research permits from local government offices, namely the regional body for planning and development (BAPPEDA), head of regional parliament (DPRD), head of the Department Of Cooperatives, heads and directors of Islamic microfinance institutions, and village leaders. Acquiring these permits was done during our first stay in Pasuruan Regency.

Support for this research project was high amongst local authorities, owing to their familiarity with us. Moreover, they were aware of the limitations of previous research into the links between microfinance, poverty, and environmental awareness, particularly in this region. Thus, they provided support in not only approving all permits, but providing secondary data wherever available, assisting with contacting key people for our interviews, and asking village leaders to support the research program. 


\subsection{Site Selection and Sampling Techniques}

The study was conducted in Pasuruan Regency, East Java. The rationale behind the selection of this location was based on several considerations:

1. Pasuruan Regency is home to a large number of Islamic microfinance institutions (IsMFIs), and which are often used as standard-bearers in Islamic microfinance. The institutions in this location were often visited and studied by policy-makers, other microfinance and financial institutions, NGOs, and financial authorities from other countries, such as Malaysia and the United States. Furthermore, the establishment of some Islamic boarding schools (pondok pesantren) and Islamic organizations, including Nahdlatul Ulama (the largest religious organization in Indonesia), in this area supported the development of the institutions.

2. Pasuruan Regency still had a high poverty rate, with high percentages of poor and very poor (Figure 3.1). Additionally, this district is located in a tapal kuda (horseshoe region), categorized with poor knowledge amongst its inhabitants and poor infrastructure in the form of roads, electricity, markets, financial institutions, health services, and educational institutions.

3. For logistical reasons, it was imperative that our research area have a varied landscape. Since this area was composed of a number of regions with their own geographical characteristics, analyzing and comparing the different roles microfinance played in regions with differing environmental conditions was made possible.

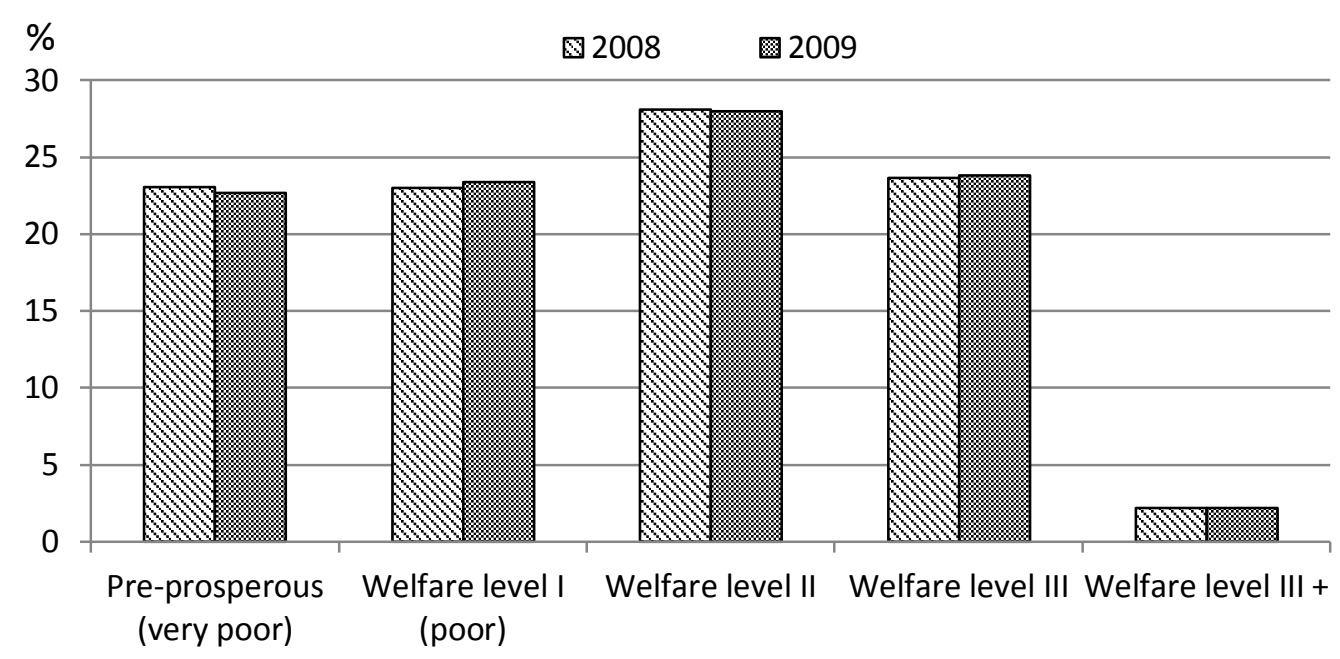

Figure 3.1: Level of welfare in the research site. Source: BPS Kabupaten Pasuruan 2010, with modification. 
Selection of three different regions was based on the recommendations of IsMFI directors and local government officials, and requirements that each region have different geographical characteristics and main economic sectors. Each site, one a lowland area, one coastal, and another an upland area, fulfilled these requirements as follows:

1. The lowland area, found in the center of Pasuruan Regency, occurred at 0-25 $\mathrm{m}$ a.s.l. Because of its seven rivers and fertile soil, its inhabitants predominantly grew rice.

2. The coastal area, found in the northern part, occurred at 0-100 m a.s.l. Its inhabitants were predominantly fishermen, or otherwise fish processors or fish traders. With the only river access in this region containing water high in salinity, agriculture was largely impossible, and thus dependence on marine resources was high.

3. The upland area, found in the southern part of Pasuruan Regency, occurred at $100-500$ $\mathrm{m}$ a.s.l. Agroforestry was the predominant method of income generation, with inhabitants growing trees, such as kapok and sengon. Manufacturing was also more prominent here than in the other areas.

Upon determining the three research areas, representative villages from each area were considered, along with the length of Islamic microfinance's establishment in the area, financial performance of its IsMFIs, and number of clients who received financing. These considerations were also useful during the respondent selection process.

\subsection{Data Collection}

Statistics on Islamic microfinance performance were collected from the Center for Micro Enterprise Incubation (PINBUK). Data on cooperative distribution was obtained from the head of the Cooperative Office of Pasuruan Regency. All other statistical data of Pasuruan Regency were provided by BPS and BAPPEDA, the regional statistics offices.

Field research, which took place over two separate two-month periods, had two approaches; quantitative and qualitative. Qualitative data are usually used for measuring incomputable behaviors using words or images as data. They are also known as categorical data, because all the data can be classified into several categories, such as class, individual, object, or process (Singh 2007, 123). On the other hand, quantitative data are usually used to compute a descriptive statistic, average, range, chart, or plot (Gillham 2000, 80). In our case, the quantitative approach comprised standardized and semi-structured questionnaires, and the qualitative approach comprised in-depth interviews, direct observations, and focus group discussions. The questionnaires for the standardized and semi-structured interviews were tested and re-tested by 
untargeted respondents until they were of appropriate conciseness, depth, and simplicity. After conferring with the microfinance experts, the questionnaires were then finalized. Seventy-two questionnaires and 18 in-depth interviews were completed in the first two-month period, and 142 questionnaires and 22 in-depth interviews were completed in the second two-month period. Of these 214 questionnaires, 34 were excluded from analysis to balance the interview numbers across regions, resulting in a total of 180 questionnaires. Of the 40 in-depth interviews, 10 were also excluded from analysis to balance the interview numbers across regions and account for missing information, resulting in a total of 30 in-depth interviews. During the first two-month period, 12 semi-structured interviews were conducted with stakeholders and key informants, microfinance experts, managers of financial institutions, village leaders, and politicians, while 13 were conducted in the second two-month period. Of these 23 semi-structured interviews, one was excluded from analysis because of missing information, resulting in a total of 22 semistructured interviews. Five focus group discussions with MFI representatives were conducted in the second two-month period; three in the lowland area with a different set of representatives each time, one the coastal area, and one in the upland area.

The resulting dataset of the questionnaires, interviews, and focus group discussions was 180 questionnaires, 30 in-depth interviews, 22 semi-structured interviews, and five focus group discussions.

Additional secondary data were obtained shortly before the writing of this manuscript. MFI distribution data in Indonesia for the years 2009 and 2011 were provided by the Ministry of Cooperative and Small and Medium Enterprises. Statistics on Islamic banking and microfinance growth in Indonesia were acquired from Bank Indonesia.

\subsubsection{DIRECT INTERVIEWS AND OBSERVATIONS}

Quantitative interviews involved standardized questionnaires and semi-structured interviews. Respondents for these quantitative interviews were selected through a randomized sampling procedure, based on information provided by the directors of Islamic MFIs and village leaders, and criteria that clients had received at least one period of financing or credit and ran their own business.

Each area shared several characteristics relevant to our research questions. For example, all of them had clients of both conventional and Islamic microfinance institutions, who adopted financing or credit schemes, who ran small businesses, and had traditional or strong cultural influences. The standardized questionnaires focused on the demographics and socio-economic 
information of respondents, as well as their perceptions of financial institutions, both Islamic and conventional. Additionally, questionnaires asked respondents of the impact of microfinance institutions on poverty alleviation, environmental awareness, and empowerment. We conducted face-to-face interviews and directly explained questions when respondents had difficulties answering or understanding them. When answering, respondents were given the freedom to explain their answers in as a detailed a manner as they preferred. They were also given the opportunity to elaborate on any research topic after the interview, should they choose to do so. In this study, we employed both quantitative and qualitative methods in such a way that we counted and classified the respondents' questionnaire answers while conducting the in-depth interviews with them (Gillham 2000, 46). Sometimes, the in-depth interview was conducted immediately after the standardized questionnaire was completed.

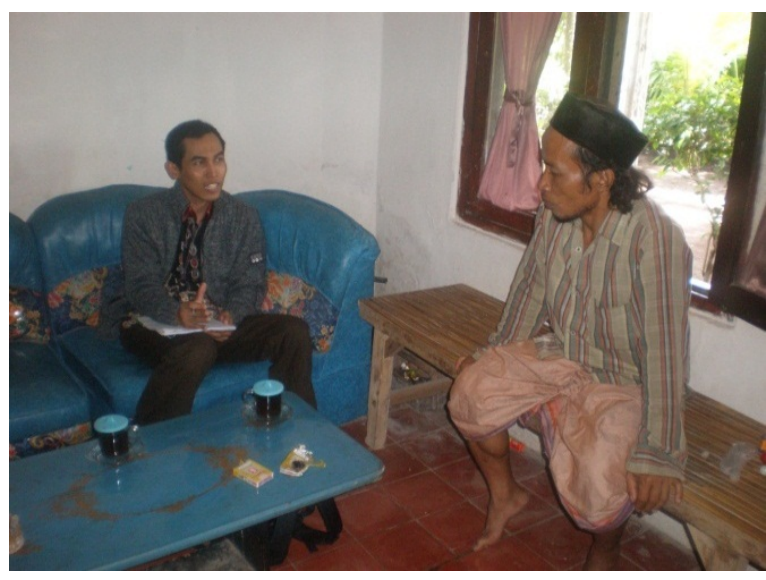

Figure 3.2: Conducting an interview.

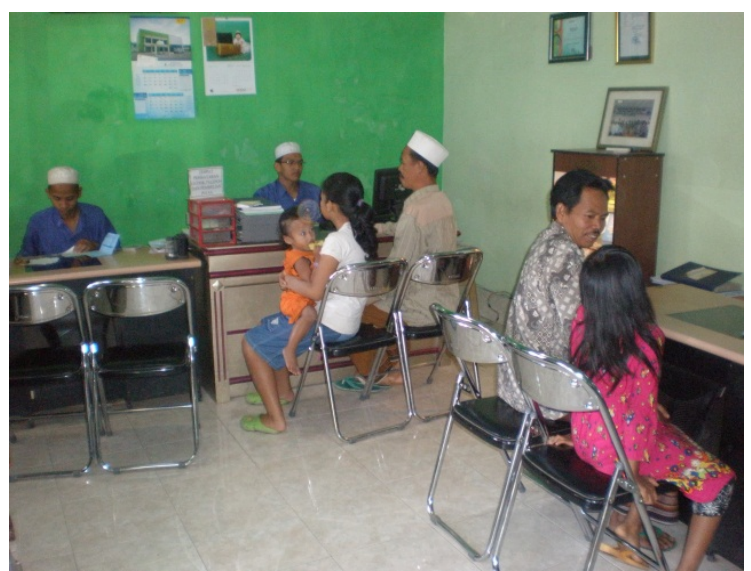

Figure 3.3: Direct observation of clients' transactions in an MFI.

In order to understand clients' attitudes and perceptions of microfinance institutions and their impacts, the qualitative method used a purposive sampling method, in which the participants were selected based on the study purpose and matched to the research question and theoretical framework.

Several techniques, such as direct observations, research notes, in-depth interviews, and focusgroup discussions, were used to collect data. Additionally, multiday stays in the research areas during the study period enabled further monitoring of the clients' activities, as well as allowing us to discuss their experiences with microfinance institutions in further detail, such as their changes in welfare and environmental awareness after joining their institution. To reduce the effect of bias or pressured responses, MFI officials were requested to not attend the respondent interviews. In some cases, however, respondents were still hesitant to say something negative about their experience, or preferred to be unclear so as not to offend their MFI. On these 
occasions, great care was taken to understand the true meaning of their statements, whether through repeated questioning or direct observations (Ritchie and Lewis 2003, 156). Their information would also be corroborated through direct observations and meetings with their relatives, colleagues, and MFIs.

\subsubsection{IN-DEPTH INTERVIEWS AND FOCUS GROUP DISCUSSIONS}

In-depth interviews were conducted to get more information from the household surveys. The respondents were purposively chosen from multiple levels of society, namely household members, village leaders, local politicians, microfinance experts, and institutions' officials. The purposes of these in-depth interviews were to: a) identify the differences between conventional and Islamic MFIs in financial schemes, client management strategies, monitoring systems, funding sources, and development, as well as their effects on poverty alleviation and environmental awareness in the three research areas, and b) investigate the effects of both Islamic and conventional MFIs on the poverty alleviation and environmental awareness of their clients. Respondents were asked about how they joined their MFI, their business activities, and the effects of their institution on their economic welfare and environmental awareness. Key informants, specifically, were asked of the roles of Islamic MFIs, compared with those of conventional ones, in poverty alleviation and environmental awareness.

Thirty people were interviewed, 10 from each research site with five them clients of Islamic MFIs and the other five clients of conventional MFIs, along with a further 22 key informants, comprising Islamic MFI officials, politicians, village leaders, microfinance experts, and the head of the local cooperative office.

The focus group discussions, which we conducted in each area and allowed participants to deliver ideas and experiences regarding our research questions, were used to support and validate our interview data and direct observations. These discussions focused on the strategies and policies of institutions to reduce poverty and environmental degradation. 


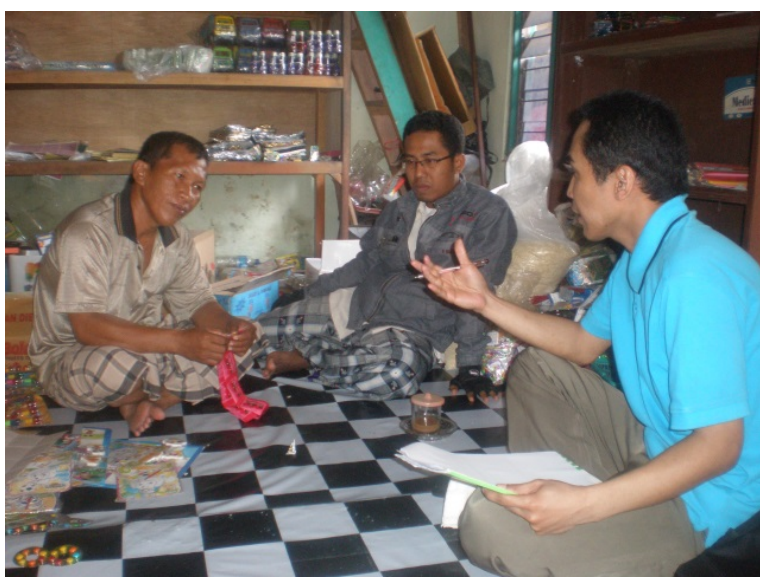

Figure 3.4: An in-depth interview.

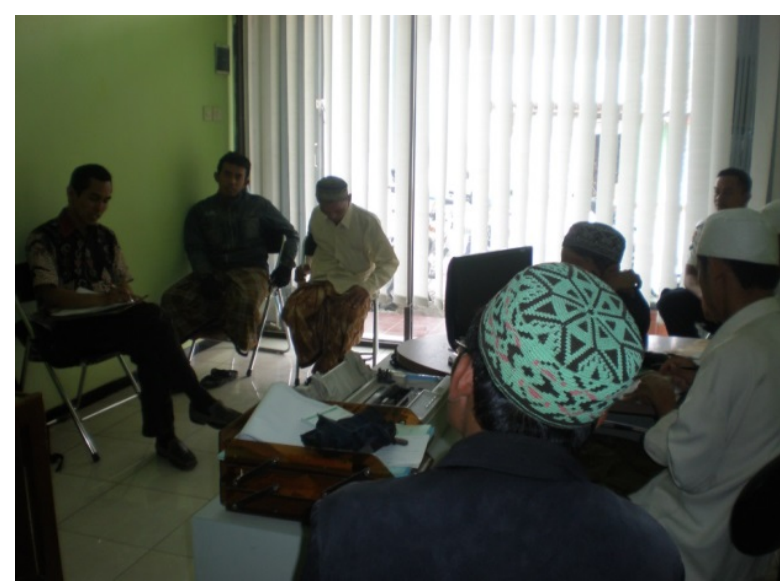

Figure 3.5: A focus group discussion in a client's shop.

Extensive use was made of field notes during all the interviews, focus group discussions, and direct observations. Observations of the attitudes of respondents, states of clients' businesses and institutions, levels of infrastructure in each village, and environmental conditions were all written down. Photographs were also taken of businesses, markets, examples of environmental degradation, and other facets specific to each region.

\subsubsection{OTHER DATA SOURCES}

Secondary data were collected in print-books, journals, magazines, and bulletins_and electronic_-statistics only found online and maps-media. Data on Islamic microfinance performance were obtained from the Center for Micro Enterprise Incubation (PINBUK), data on cooperative distribution from the head of the Cooperative Office of Pasuruan Regency, data on MFI distribution in Indonesia for the years 2009 and 2011 from the Ministry of Cooperative and Small and Medium Enterprises, and data on Islamic banking and microfinance growth in Indonesia from Bank Indonesia. Other statistical data of Pasuruan Regency were provided by Pasuruan Regency's Center of Statistics (BPS) and the Regional Body for Development and Planning (BAPPEDA). Information on individual villages was provided by their village leaders, and regional information was provided by the head of the Regional Cooperative Office. These secondary data enabled us to theoretically and empirically compare the participants in our study with the available data, and see whether their experiences formed part of a greater trend in Indonesia. 


\subsection{Data Evaluation and Validation: Triangulation and a Logic Model Approach}

Methodological triangulation refers to the use of multiple research methods in the examination of a social phenomenon (Mathison 1988), in an effort to decrease, negate, or counterbalance the deficiency of a single strategy (Tobin and Begley 2004). Denzin (1971) and Thurmond (2001) state that triangulation is the combination of at least two or more theoretical perspectives, methodological approaches, data sources, investigators, or data analysis methods. In our study, triangulation was used to validate and test interview and secondary data. Thematic and categorization analyses were used to analyze the qualitative data. The categories in these analyses were made to describe the key research issues and based on the research aims. As Ritchie and Lewis (2003, 219-222) argue would be the case, this was able to produce a number of concepts that were prevalent throughout the data. For our study, the main categories to be determined were: regional differences in how borrowers are affected, in terms of poverty alleviation and environmental awareness, by Islamic and conventional microfinance; regional differences in institutional performance of both Islamic and conventional MFIs; impacts of Islamic and conventional microfinance on poverty reduction; impacts of Islamic and conventional microfinance on environmental awareness; impacts of Islamic and conventional microfinance on business performance; and impacts of Islamic and conventional microfinance on welfare. The important issues and themes obtained from the fieldwork were grouped into these categories. To ensure the data were valid and reliable (Golafshani 2003), the qualitative data that were obtained through interviews and observations were then examined using methodological triangulation.

A logic model is a program evaluation tool illustrating —with a diagram or picture—-the logical linkages between program inputs, activities, outputs, clients reached, and short-, medium-, and long-term outcomes (McLaughlin and Gretchen 1999). More simply, it is a picture or diagram showing what is going to be done, and what the expected results of the program or evaluation are (Farell et al. 2002), or a method of identifying and measuring the impacts of systems, organizations, or institutions (Julian 1997). In our analyses, a logic model was used to understand the system impacts of Islamic microfinance or community goals through the implementation of multiple short-term interventions (Figure 3.6). 


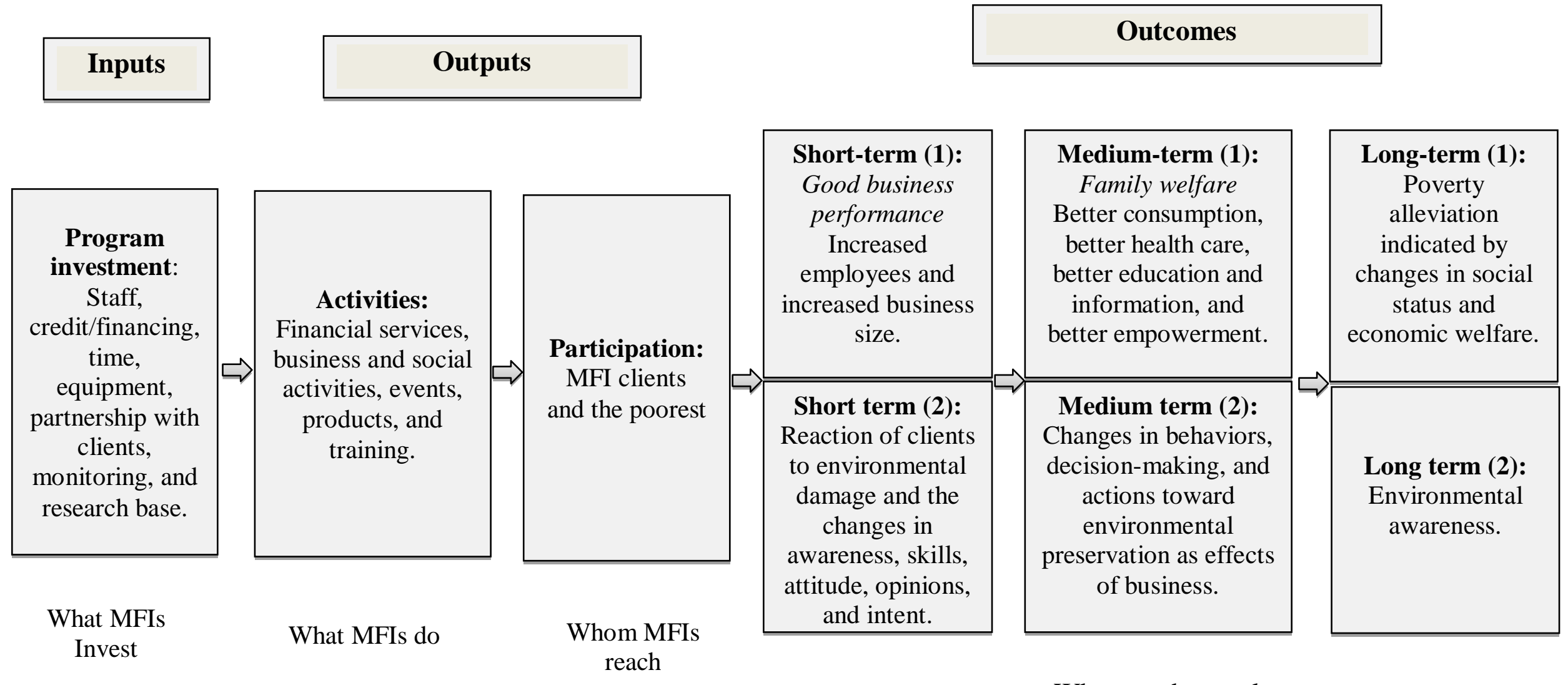

Figure 3.6: The logic model of Islamic MFIs' roles in poverty alleviation and environmental awareness. 
For the creation of our logic model, we referred to Taylor-Powell and Henert (2008). Inputs in the model were staff, credit/financing, time, equipment, partnership with clients, monitoring, and research base. In terms of outputs, institutions provided financial services, business and social activities, events, products, and training as their activities, and reaching clients and the poorest as participation. The provision of services, activities, events, products, and training included workshops, conferences, counseling, and various schemes, while the reach extended to clients, groups, families, and organizations. The resulting outcomes were short-, medium-, or long-term, and affected individuals, families, groups, businesses, communities, and local systems. Short-term benefits were improved business performance-as indicated by increases in employee numbers and business size-and changes in environmental awareness, skills, attitudes, opinions, and intent. Medium-term benefits were improvements to family welfarewith better consumption, health care, education and information, and empowerment-and changes in behaviors, decision-making, and actions toward environmental preservation as effects of business. Long term benefits were in poverty alleviation-seen in social status and economic welfare-and environmental awareness.

\subsection{Data Analyses}

After two phases of conducting fieldwork surveys, data were checked and re-checked for missing data or inconsistencies, as well as inconsistencies in the questionnaire results. Then, interview data were analyzed data using SPSS (versions 16 and 18). Microsoft Excel 2010 was used for additional calculations of percentages.

Data analysis was also done using quantitative and qualitative approaches. After validating and evaluating data through the logic model and triangulation, we started the data analysis process. The qualitative analysis was used to describe the behavior of the people in our research area, particularly towards changes in their economic welfare and awareness of specific environmental issues after joining a microfinance institution. Data analysis using the quantitative method was carried out after re-checking data and inputting them into SPSS. We referred to Fernandes (2009, 11-14), Singh (2007, 134-140), and Taylor and Cihon (2004, 48-51) for our quantitative data analysis through various descriptive statistics to present information about variables:

1. Frequency distribution, as a tabular summary of data, showed the percentage of each variable in each class, giving a picture of the economic and social conditions of the participants in each area. This tabular summary was divided into two forms, frequency 
tabulations and cross-tabulations. Cross-tabulation was the easiest way of summarizing data, and could be any size in terms of rows and columns. While frequency tabulation was used to describe numbers and percentages of variables related to the role of Islamic microfinance in alleviating poverty, increasing environmental awareness, and empowerment.

2. Numerical summaries measured the central tendencies, which consisted of mean, median, minimum, maximum, and average values of observations. It provided information about the central location of a distribution. 


\section{Overview of the Research Area}

\subsection{Geography}

Pasuruan Regency (0-1000 m a.s.l., 7.30'-8.30'S and 112.30'-113.30'E) is located in East Java, northeast of Surabaya, the capital of East Java Province. Geographically, the region is strategically significant, because of its connecting roads between the cities of Surabaya and Malang, and Surabaya and Banyuwangi. This centrality has influenced investors seeking to create and develop businesses in rural regions with sufficient intercity infrastructure. Important districts adjacent to our research area are Mojokerto Regency to the west, the cities of Malang and Batu to the south, Probolinggo to the east, and Pasuruan, Sidoarjo Regency, and the Madura Strait to the north. With an area of 147,401.5 hectares, Pasuruan Regency has 24 subdistricts and 365 villages. The three research sites, Nguling, Kraton, and Purwosari Subdistricts, and their surrounding subdistricts, are shown in Figure 4.1.

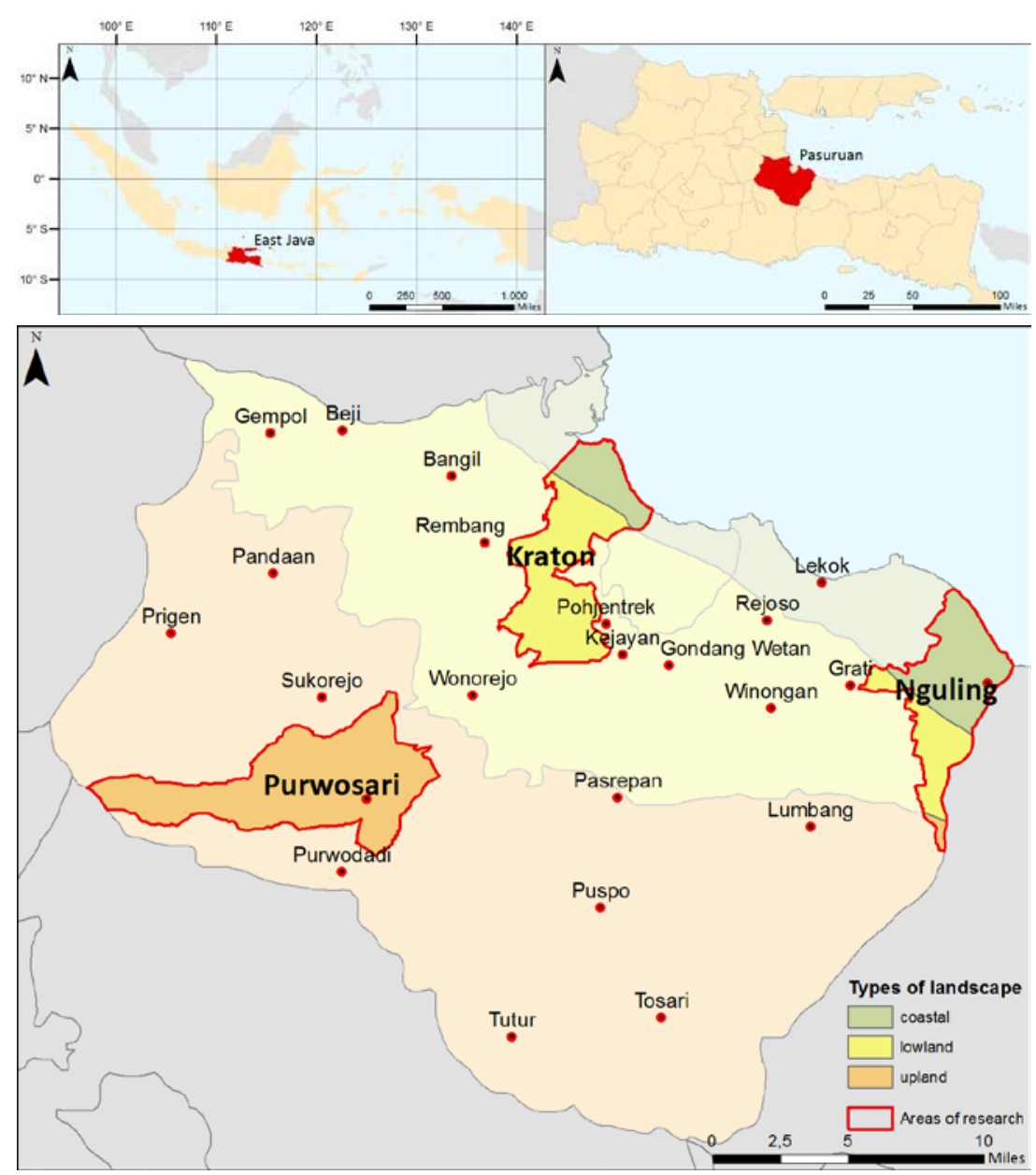

Figure 4.1: Map of East Java and the research area of Pasuruan Regency. The three sites-lowland area of Kraton Subdistrict, coastal area of Nguling Subdistrict, and upland area of Purwosari Subdistrict—are highlighted. 
We refer to the locations in which we conducted this research as lowland, coastal, and upland. Our sampling sites were determined mostly by the location of the sites relative to different geographical areas of Pasuruan Regency. The livelihoods of the inhabitants in the three different locations were also considered. In addition, a requirement of each site was the presence of Islamic microfinance institutions. The research areas were situated in the northern, middle, and southern parts of Pasuruan Regency. The lowland area of Kraton Subdistrict, where rice production formed the majority of people's livelihoods, was located in the center (Figure 4.2). Although a small part of Kraton Subdistrict was situated on the coast, data were collected only from respondents living in the southern three-quarters of the subdistrict, which was characterized as lowland. The coastal area of Nguling Subdistrict, in which most people relied on marine resources for their income generation, was located in the north (Figure 4.3). Meanwhile, the upland area of Purwosari Subdistrict was located in the southwestern part of Pasuruan Regency (Figure 4.4). The majority of people in this subdistrict relied on agroforestry, which encompassed growing kapok and sengon trees, and coffee and cloves. A minority also grew rice, vegetables, and fruits in certain seasons.

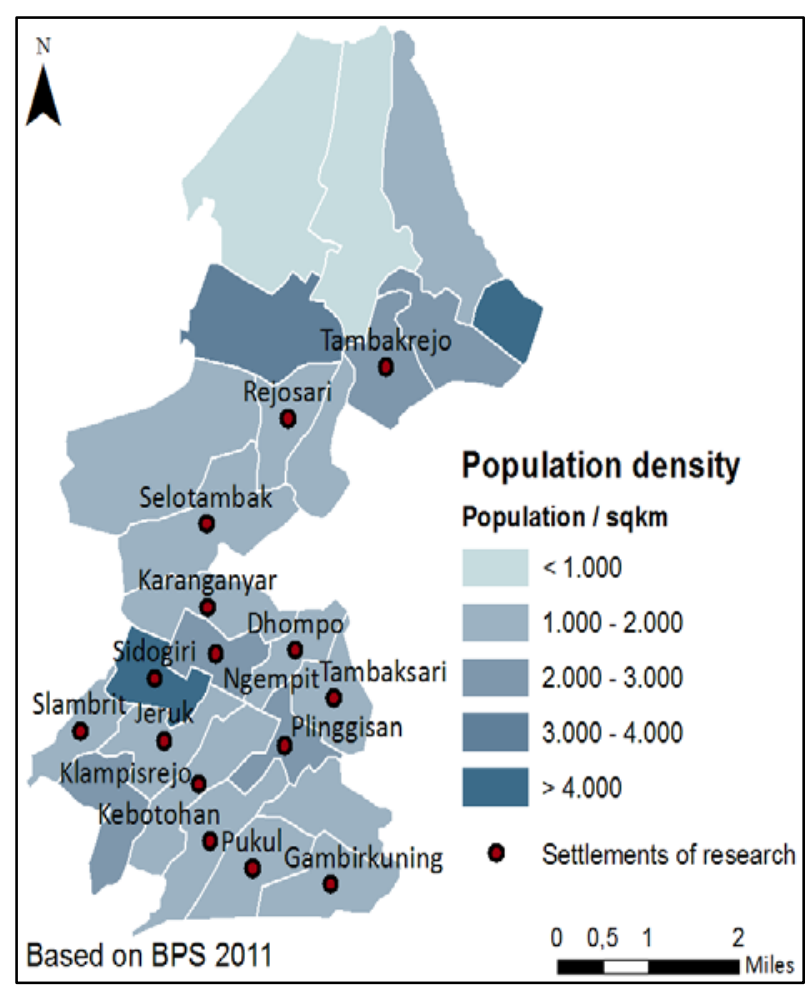

Figure 4.2: Lowland area of Kraton Subdistrict.

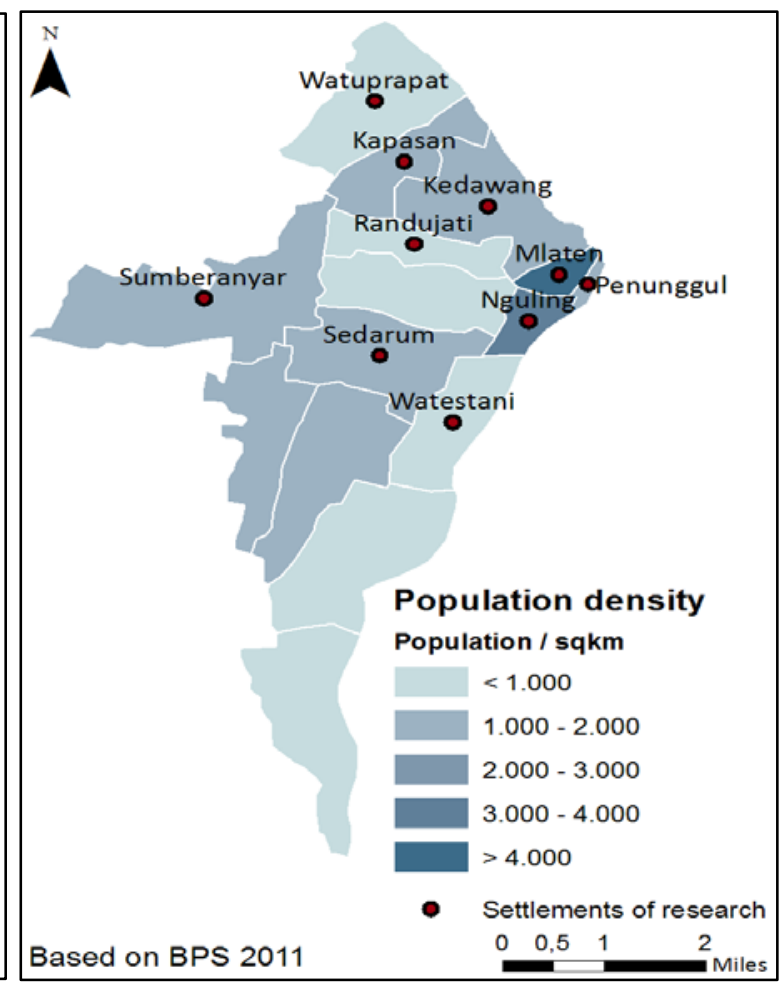

Figure 4.3: Coastal area of Nguling Subdistrict. 


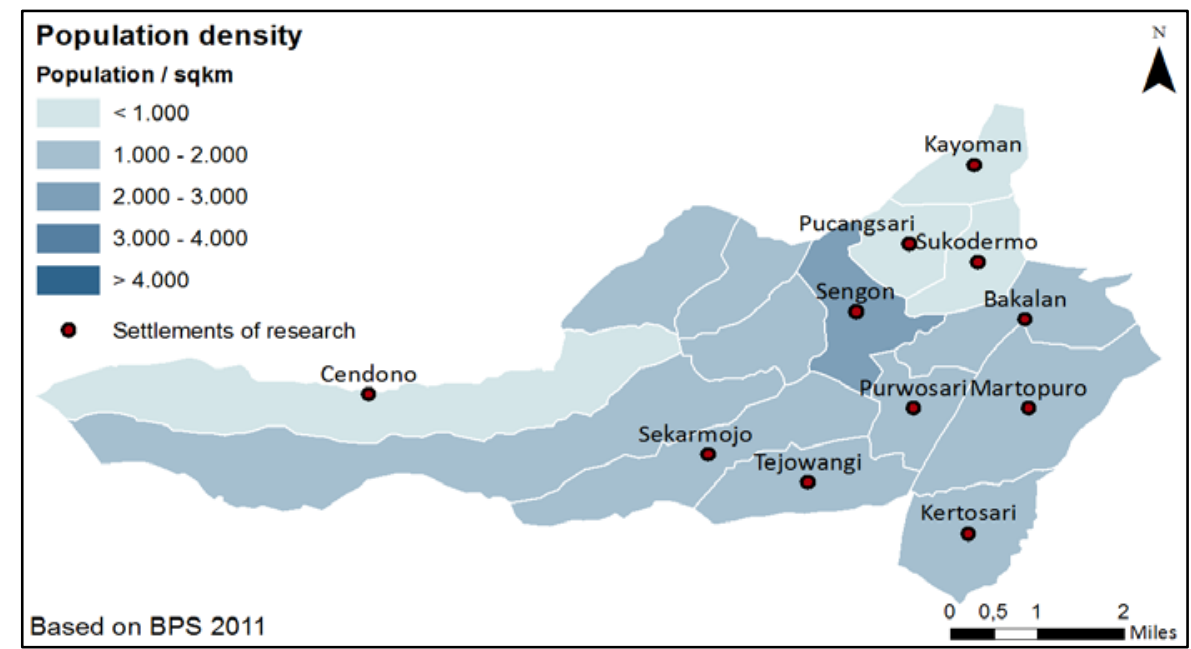

Figure 4.4: Upland area of Purwosari Subdistrict.

\subsection{Topography and Climate}

The landscape of Pasuruan Regency varies, with elevations ranging from 2-8 $\mathrm{m}$ a.s.l in the coastal area, to 6-91 m a.s.l in the lowland area, to 180-3000 m a.s.l in the upland area (BPS Kabupaten Pasuruan and BAPPEDA 2009). Approximately $66.85 \%$ of the landscape falls under the gentle slope category ( $0-14^{\circ} 59^{\prime}$ degrees), $15.07 \%$ falls under the moderate to steep slope categories $\left(15^{\circ}-40^{\circ}\right)$, and $18.08 \%$ falls under the very steep slope category of over $40^{\circ}$ (BPS Kabupaten Pasuruan 2010; Tang 2000).

Located on the equator, our research area is limited to two seasons: rainy and dry. The rainy season lasts from October to April, while the dry season lasts from May to September (BPS Kabupaten Pasuruan 2010). Temperatures range from 24 to $32{ }^{\circ} \mathrm{C}$, with the southern, upland, part averaging $5{ }^{\circ} \mathrm{C}$ less than the rest of Pasuruan Regency. Annual rainfall, meanwhile, ranges from 1,500 to $2,500 \mathrm{~mm}$.

\subsection{Demography, Hydrography, and Land Use}

With an area of 147,401.5 ha and population of 1,475,365 in 2009, Pasuruan Regency had a population density of 1,001 people per $\mathrm{km}^{2}$ (BPS Kabupaten Pasuruan 2010). Of the 1,475,365 people, 1,125,318 were of productive age, but just 756,445 were employed. Of these, 49.70\% worked in the agricultural sector, $18.59 \%$ worked in the public sector, $11.92 \%$ were selfemployed, $12.72 \%$ worked in the service industry, and $7.07 \%$ were traders. Pasuruan Regency is also home to various ethnicities, with the majority being Javanese, Madurese, and Tenggerese.

A large number of water sources are found within the borders of Pasuruan Regency. Its seven rivers are the Lawean, Rejoso, Gembong, Welang, Masangan, Kedunglarangan, and Petrung. 
Ranu Lake is the single lake found in the region, and Umbulan is a wellspring located in the northeast, between Kraton and Nguling. Ranu Lake discharges 5,650 m³/s, enabling it to support not only the inhabitants of Pasuruan Regency, but its surrounding regencies, as well.

Land use in our research area was dependent on a region's natural resources and environmental condition. For example, in the coastal area, people relied on fishing because of their proximity to the Madura Strait. On the other hand, agriculture was low in this area, because soil fertility was low and water sources were of too high salinity to be of use. The lowland area, with the highest soil fertility and most water sources, had the most intense agriculture of the three regions. Agroforestry was the predominant form of land use in the upland area, with the trees and plants being grown, such apple, coffee, and avocado, not being found in the lowland or coastal areas. Although rice was also grown, the lower soil fertility and fewer rivers meant that this was much less common than in the lowland area.

\subsection{Socio-economics and Financial Institutions}

The people of Pasuruan Regency were heavily dependent on the primary sector for their livelihoods, farming, fishing, and raising livestock to generate their incomes. Time-series data revealed the increasing trend of agriculture; from 2006 to 2009, the prevalence of agriculture steadily increased, from $3.05 \%$ in $2006,3.07 \%$ in 2007 , $3.20 \%$ in 2008 , to $4.56 \%$ in 2009 (BAPPEDA and BPS Kabupaten Pasuruan 2010). Contributing factors were intensive programs from the government, such as informally educating and training farmers, or providing seed and fertilizer subsidies. Although the majority was confined to the primary sector, a significant number of people still worked in processing, manufacturing, trading, and the provision of services.

Pasuruan Regency's centrality within East Java, with its roads connecting big cities, such as Surabaya, Sidoarjo, and Malang, as well was a number of cities from the east, has spurred investor interest in local factories. Consequently, job opportunities are more lucrative in Pasuruan Regency than in many of its neighbors in East Java (Governor of East Java 2013).

Financial institutions, especially those in microfinance, are largely established with the goal of providing financial services to people for their income generation. In order to start or develop their business, poor people need financial assistance, in the form of capital or credit. If their business succeeds and they have a surplus, they are then able to save their money with their institution. In 2009, credit schemes accounted for Rp 44,444 trillion in fund mobilization, while savings schemes accounted for Rp 5.55 trillion. The highest percentage of loans was allocated to 
the processing industry, followed by the service and agricultural sectors. Additionally, 78.73\% of loans were used for working capital, followed by for investment, with 6.84\%, and consumption, with 5.85\% (BPS Kabupaten Pasuruan 2010). Credit schemes from financial institutions were not limited to micro and small entrepreneurs, but medium entrepreneurs, as well, who saw the highest percentage of credit distribution. Thus, in 2009, the total amount of credit allocated toward micro, small, and medium enterprises was Rp 17,582 trillion, with Rp 6,981 trillion going to medium enterprises, and Rp 6,270 trillion and Rp 4,331 trillion going to micro and small enterprises, respectively.

Table 4.1: Loans provided by commercial and rural banks in 2009, sorted by purpose of loan.

\begin{tabular}{lrrrr}
\hline Month & $\begin{array}{r}\text { Working Capital } \\
\text { (Rp million) }\end{array}$ & $\begin{array}{r}\text { Investment } \\
\text { (Rp million) }\end{array}$ & $\begin{array}{r}\text { Consumption } \\
\text { (Rp million) }\end{array}$ & $\begin{array}{r}\text { Total } \\
\text { (Rp million) }\end{array}$ \\
\hline January & $3,353,175$ & 410,238 & 357,511 & $4,120,924$ \\
February & $3,445,291$ & 415,055 & 359,855 & $4,220,201$ \\
March & $3,421,737$ & 405,745 & 369,146 & $4,196,628$ \\
April & $3,223,541$ & 374,272 & 368,347 & $3,966,160$ \\
May & $2,760,686$ & 360,992 & 370,667 & $3,492,345$ \\
June & $2,741,185$ & 389,750 & 413,013 & $3,508,885$ \\
July & $2,679,149$ & 386,750 & 413,013 & $3,478,912$ \\
August & $2,634,726$ & 394,785 & 396,752 & $3,426,263$ \\
September & $2,555,778$ & 383,631 & 409,963 & $3,349,372$ \\
October & $2,604,907$ & 414,414 & 417,116 & $3,436,437$ \\
November & $2,721,985$ & 407,918 & 430,466 & $3,560,369$ \\
December & $2,849,372$ & 404,843 & 433,855 & $3,688,070$ \\
\hline
\end{tabular}

Source: BPS Kabupaten Pasuruan 2010.

Some local government strategies have included establishing microfinance institutions to accelerate the development process within Pasuruan Regency. The establishment of conventional microfinance institutions in Pasuruan Regency was usually based on community demands. Koperasi Unit Desa Pertanian and Koperasi Pertanian usually provided financial services with the intention of helping people working in agriculture in the lowland area. Koperasi Perkebunan, mostly located in upland areas, helped people generate income from agroforestry products. Meanwhile, Koperasi Perikanan was a financial institution dedicated to people who depended on marine resources. Conversely, Islamic microfinance institutions were not tailored to different types of clients, basing their client selection on Islamic laws, only, thus individually serving a wider range of clients. The number and characteristics of the different types of microfinance institutions found in Pasuruan Regency is presented in Table 4.2. 
Table 4.2: Microfinance institutions in Pasuruan Regency.

\begin{tabular}{|c|c|c|c|c|c|c|c|c|}
\hline \multirow{2}{*}{ Type of MFI } & \multirow{2}{*}{ No. } & \multicolumn{3}{|c|}{ Members (people ) } & \multirow{2}{*}{$\begin{array}{r}\text { No. of } \\
\text { employees }\end{array}$} & \multirow{2}{*}{$\begin{array}{r}\text { Assets } \\
\mathrm{Rp}(000)\end{array}$} & \multicolumn{2}{|c|}{ Volume of Business } \\
\hline & & Male & Female & Total & & & Male & Female \\
\hline Koperasi Unit Desa Pertanian & 28 & 52,666 & 32,838 & 85,504 & 365 & $91,543,687$ & $123 ., 58,153$ & $60,721,073$ \\
\hline Koperasi Pertanian & 8 & 260 & 100 & 360 & 2 & 874,618 & 315,925 & 158,025 \\
\hline Koperasi Perkebunan & 7 & 184 & 70 & 254 & - & 341,397 & 30,250 & 15,725 \\
\hline Koperasi Peternakan & 43 & 53,110 & 33,008 & 86,118 & 367 & $92,759,702$ & $124,104,328$ & $60,894,823$ \\
\hline Koperasi Perikanan & 5 & 202 & 133 & 335 & 7 & 554,001 & 19,750 & 9,875 \\
\hline Koppontren & 73 & 4,020 & 1,588 & 5,608 & 275 & $12,827,198$ & $29,347,853$ & $14,882,642$ \\
\hline Kopinkra & 3 & 106 & 74 & 180 & 2 & 357,438 & 12,750 & 6,250 \\
\hline Kopti & 1 & 39 & 26 & 65 & - & 264,872 & 0 & 0 \\
\hline Kopta & 1 & 71 & 25 & 96 & - & 26,358 & - & - \\
\hline KPRI & 24 & 3,298 & 1,459 & 4,757 & 67 & $17,963,390$ & $14,032,379$ & $8,184,097$ \\
\hline Koperasi Karyawan & 112 & 16,860 & 10,039 & 26,899 & 169 & $76,958,687$ & $96,772,770$ & $96,772,770$ \\
\hline Koperasi Angkatan Darat & 1 & 414 & 1 & 415 & 2 & 991,271 & $1, .536,544$ & $1,536,544$ \\
\hline Koperasi Angkatan Laut & 1 & 18 & 12 & 30 & 0 & 9,215 & 950 & 950 \\
\hline Koperasi Kepolisian & 1 & 222 & 144 & 366 & 12 & 832,474 & 695,250 & 695,250 \\
\hline Koperasi Serba Usaha & 85 & 3,309 & 1,686 & 4,995 & 91 & $18,878,994$ & $16,511,989$ & $16,511,989$ \\
\hline Koppas & 6 & 1,027 & 765 & 1,792 & 8 & $1,168,054$ & 623,598 & 623,598 \\
\hline Koperasi Simpan Pinjam & 18 & 1,651 & 1,022 & 2,673 & 96 & $22,065,880$ & $28,143,769$ & $28,143,769$ \\
\hline Koperasi Angkatan Udara & 2 & 139 & - & 139 & 1 & 39,728 & - & - \\
\hline KBPR & 1 & 20 & - & 20 & 16 & $18,312,431$ & $53,977,800$ & $53,977,800$ \\
\hline Koperasi Wanita & 173 & 101 & 6,830 & 14,818 & 132 & $46,518,574$ & $119,719,922$ & $125,347,516$ \\
\hline Koperasi Wredatama & 4 & 219 & 443 & 662 & 1 & 600,752 & 743,415 & 743,415 \\
\hline Koperasi Pertambangan & 1 & 68 & 30 & 98 & 8 & 126,013 & 125,800 & 125,800 \\
\hline Koperasi Pedagang Kaki Lima & 2 & 156 & 81 & 237 & - & 345,882 & 918,764 & 918,764 \\
\hline Koperasi Other & 121 & 3,854 & 2,802 & 6,656 & 86 & $31.456,819$ & $17.146,227$ & $17,146,227$ \\
\hline KPTR & 1 & 44 & - & 44 & 142 & $1.758,687$ & 752,203 & 752,203 \\
\hline Koperasi Sekunder & 2 & 5 & - & 5 & 284 & $6,444,012$ & $4,854,021$ & $4,854,021$ \\
\hline BPR (Rural Credit Bank) & 25 & - & - & - & - & - & - & - \\
\hline Islamic Financial Cooperative & 25 & - & - & - & - & - & - & - \\
\hline Total & 710 & 88,236 & 59,840 & 163,321 & 1,972 & $418,565,736$ & $751,509,135$ & $553,057,829$ \\
\hline
\end{tabular}

Source: Various data from the Cooperative Office of Pasuruan Regency (April 2011), with modification. 


\section{Lowland Area}

\section{$5.1 \quad$ Introduction}

The following three chapters comprise the analysis of the three different research sites in Pasuruan Regency. Each chapter looks at the following:

1. An overview of the research site.

2. Characteristics of respondent households.

3. Performances of the area's microfinance institutions.

4. The effect of microfinance on poverty alleviation in the area.

5. The effect of microfinance on environmental awareness in the area.

Research site selection is based on geographic characteristics, age and performance of the microfinance institutions (with an emphasis on Islamic institutions), and numbers of business clients who adopted financing schemes. The three chosen study areas on which each chapter will focus are: a) a lowland area based on agricultural production, b) a coastal area based on marine resources, and c) an upland area based on forestry and agroforestry. The advantage of these sites being located in the same regency is that it allowed us to do our research more thoroughly.

The methods we employ are standardized and semi-structured questionnaires, in-depth interviews, focus group discussions, and secondary data. To examine the role of Islamic microfinance institutions (IsMFIs) on poverty alleviation and environmental awareness, we take a multistage approach toward data collection. Using this approach, 71 respondents are interviewed in each area. However, because of missing information and imbalanced interview numbers, 11 interviews are eliminated for a total of 60 participants per research area, of which 10 are in-depth. In addition, 22 key informants in Pasuruan Regency are also interviewed.

\subsection{Overview of Research Area}

Generally, the lowland area of Kraton Subdistrict was flat with fertile soil. Three rivers-the Welang Bawah, Kedung Pengaron Cerame, and Sumbersuko-flowed within the region to supply water to the rice fields. Our study was located in the center of Pasuruan Regency (0-25 m a.s.l., 7.30'-8.30'S and 112.30'-113.30'E). Most of the respondents derived their income from the agricultural sector, growing products such as rice, corn, and soybean, and doing other offfarm activities. We chose the site based on the recommendations of the leaders of a number of microfinance institutions, and taking into consideration factors such as the presence of potential 
microfinance institutions, eligible clients, and whether financing was used for commercial rather than personal purposes.

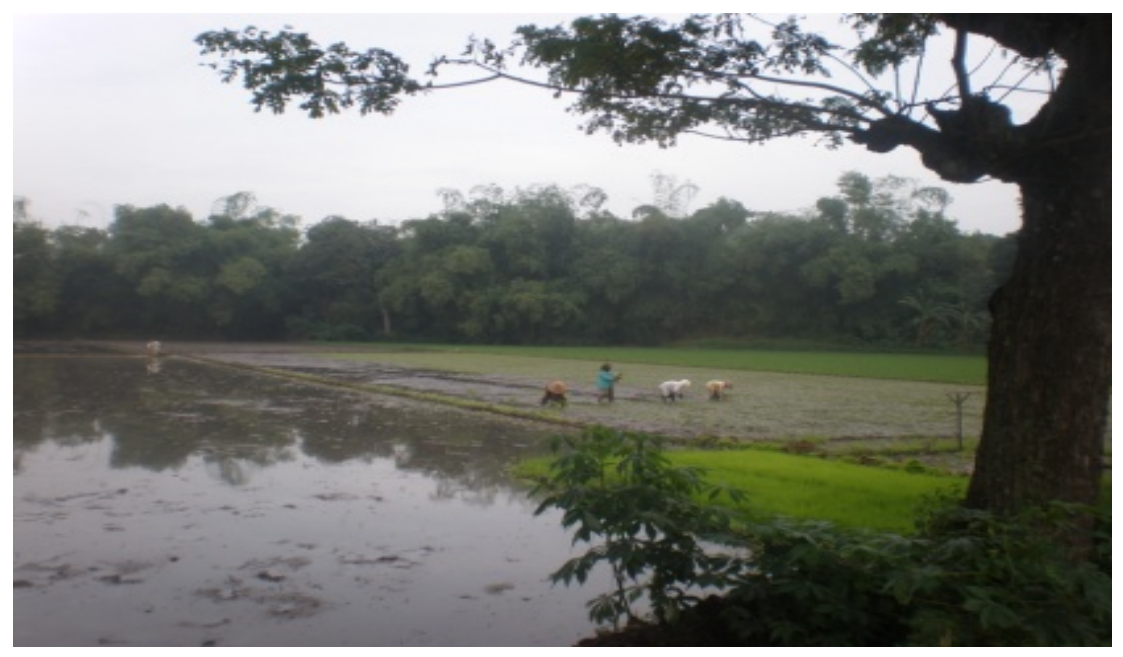

Figure 5.1: Farmers growing rice.

Demographically, the people were classified as of productive age (Figure 5.2).

Female

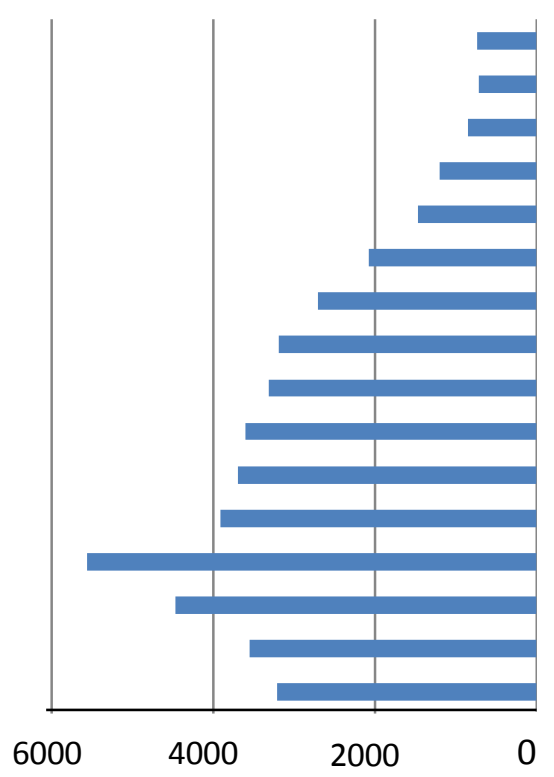

Male

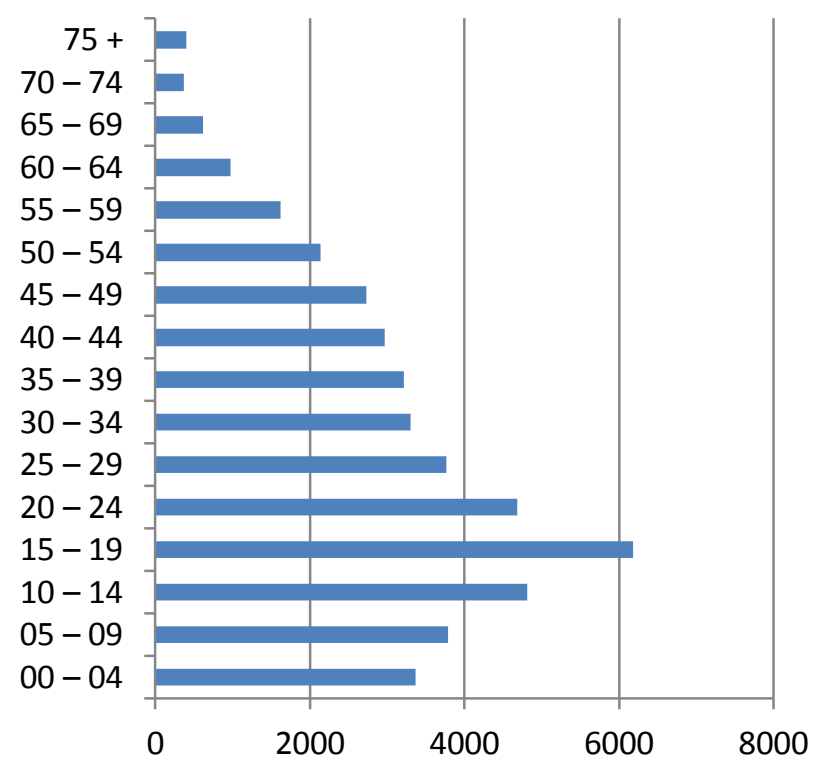

Figure 5.2: The population by age group. Source: BPS, Statistic of Pasuruan Regency, Kraton In Figures (2011), with modification.

Although the Ministry Of Education ran social programs directed toward allowing people to finish senior high school, the highest percentage of respondents only completed elementary school, only (Table 5.1). 
Table 5.1: Education level of local people in research site.

\begin{tabular}{lrr}
\hline Level of schooling & No. of people & Percent \\
\hline No/some elementary school & 17,330 & 27.38 \\
Completed elementary school & 31,940 & 50.46 \\
Completed junior high school & 8,254 & 13.04 \\
Completed senior high school $^{1}$ & 4,991 & 7.88 \\
Completed diploma program $^{1}$ & 246 & 0.39 \\
Academy/university & 513 & 0.81 \\
Master/doctoral degree & 28 & 0.04 \\
\hline Total & 63,302 & 100.00 \\
\hline
\end{tabular}

Source: BPS, Statistic of Pasuruan Regency, Kraton In Figures (2011), with modification.

Though susceptible to annual flooding, the infrastructure of the region, such as roads, places of worship, bridges, rural markets, health centers, financial institutions, and other public facilities, was nevertheless well-maintained by the local officials, and provided a meaningful service to the livelihoods of the locals. Off-farm sources of income for the communities included processing, construction, selling crafts, manufacturing furniture, trading, and working in the service industry (Figure 5.3).

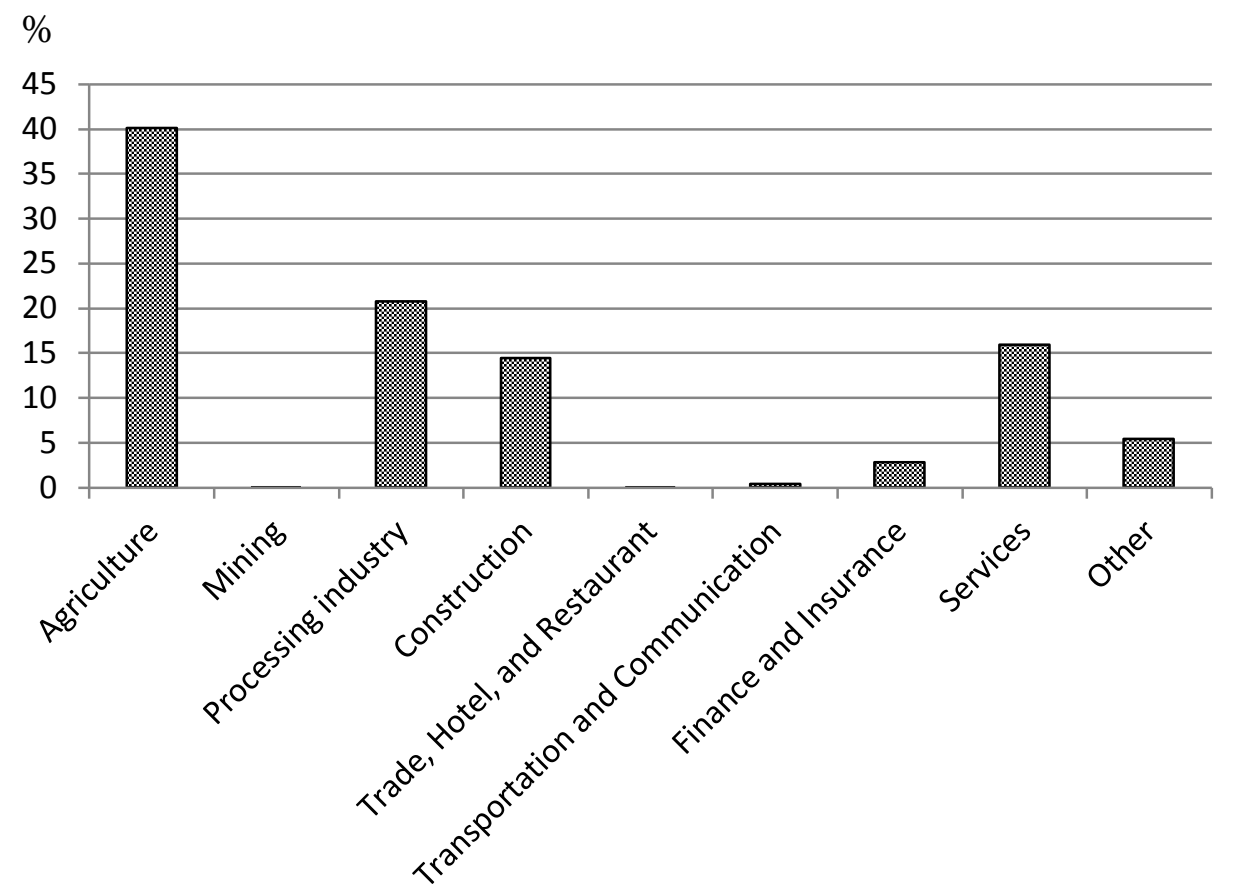

Figure 5.3: Income sources of the people in the lowland area of Kraton Subdistrict. Of 89,128 people, 33,005 (37.07\%) are employed. Source: BPS, Statistic of Pasuruan Regency, Kraton In Figures (2011), with modification.

\footnotetext{
${ }^{1}$ A diploma program takes one to three years to complete, and is more vocational than a university program. The certificate obtained is equivalent to an associate degree.
} 
Because the welfare of the people in our study area was affected primarily by the agricultural sector, they were vulnerable to the annual floods that occurred in the region-particularly during the rainy season-as these floods would have a negative impact on their production yields.

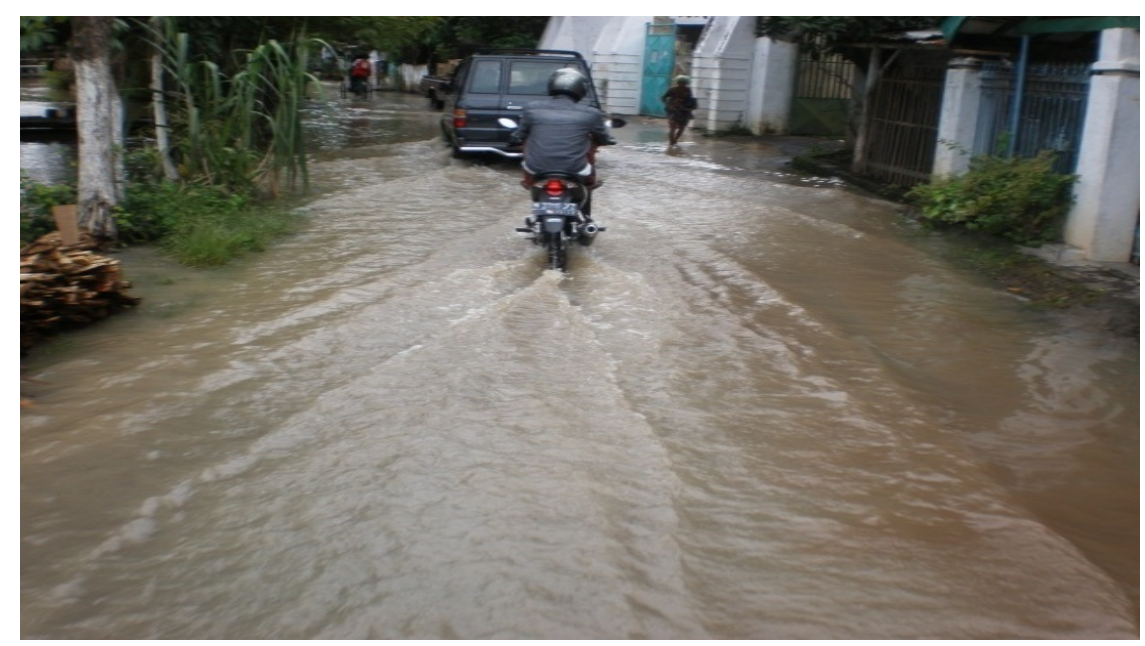

Figure 5.4: Flooding in the lowland area of Kraton Subdistrict.

The National Family Planning Coordinating Board (BKKBN) uses certain indicators to measure welfare levels. Based on the BKKBN standard, a low welfare level is indicated by an inability to fulfill basic needs such as adequate nutrition (characterized as very poor); or an ability to fulfill those needs, but inability to obtain things such as adequate clothing, housing, or healthcare (characterized as poor). The lowland area was categorized as a poor region because the number of very poor (24.03\%) and poor people (27.18\%) was still high (Table 5.2).

Table 5.2: Level of welfare in the research site.

\begin{tabular}{lrr}
\hline Level of Welfare & No. of people & Percent \\
\hline Pre-prosperous (very poor) & 5,164 & 24.03 \\
Welfare level I (poor) & 5,841 & 27.18 \\
Welfare level II & 5,613 & 26.12 \\
Welfare level III & 4,614 & 21.47 \\
Welfare level III + & 259 & 1.21 \\
\hline Total & 21,491 & 100.00 \\
\hline
\end{tabular}

Source: BPS, Statistic of Pasuruan Regency, Kraton In Figures (2011), with modification.

\subsection{Characteristics of Respondent Households}

The participants were divided into several categories: clients of Islamic microfinance institutions, client of conventional microfinance institutions, and key informants. 
The people's livelihoods were based in the agricultural and off-farm sectors. Quantitative data presenting the economic activities of the household's head is presented in Table 5.3.

Table 5.3: Economic activities of head of household.

\begin{tabular}{lrr}
\hline Main occupation & No. of respondents & Percent \\
\hline Self-employed in agriculture (farming) & 23 & 38.33 \\
Self-employed on off-farm enterprises & 25 & 41.67 \\
Government employee & 2 & 3.33 \\
Casual worker & 5 & 8.33 \\
Salaried worker in non-agriculture & 5 & 8.33 \\
\hline Total & 60 & 100.00 \\
\hline
\end{tabular}

$\mathrm{N}=60$. Source: fieldwork conducted in the lowland area.

Table 5.3 shows that $41.67 \%$ of respondents were self-employed on off-farm enterprises. These economic activities were, for example, providing agriculture-related services such as the renting of tractor engines to farmers, producing furniture, making handicrafts, and selling agricultural supplements. A slightly smaller number, 38.33\% generated their income from self-employed crop production, which included growing rice, corn, and peanuts. Respondents who worked as government employees, casual workers, or salaried workers in non-agricultural sectors accounted for around $20 \%$ of the respondents. Nevertheless, $20 \%$ of the respondents had other jobs in the agricultural sector serving as second incomes.

The education level of the head of a household affects the livelihood of the children. The better a parent's education, the more livelihood opportunities for the family (Brown and Park 2002). Table 5.4 shows the education level of each head of household in the lowland area.

Table 5.4: Education level of household's head.

\begin{tabular}{lrr}
\hline Level of formal education & No. of respondents & Percent \\
\hline Never attended school & 2 & 3.33 \\
Some elementary school & 8 & 13.33 \\
Completed elementary school & 22 & 36.67 \\
Attended junior high school & 3 & 5.00 \\
Completed junior high school & 12 & 20.00 \\
Attended senior high school & 1 & 1.67 \\
Completed senior high school & 7 & 11.67 \\
Attended academy/university & 5 & 8.33 \\
\hline Total & 60 & 100.00 \\
\hline
\end{tabular}

$\mathrm{N}=60$. Source: fieldwork conducted in the lowland area.

Of the respondents, 36.67\% completed elementary school, whereas $13.33 \%$ did not, and a further 3.33\% never attended school. The number of heads of household who graduated from junior 
high school was relatively high, 20\%, while those who graduated from an academy or university was accounted for $8.33 \%$. A low level of education is reported to be one of the causes of poverty (Wilson 2002; Klasen 1997; The World Bank 1995). Based on our data, it is possible that this was also the case in the lowland area of Kraton Subdistrict.

Table 5.5: Age of each household's head.

\begin{tabular}{lrr}
\hline Age distribution & No. of respondents & Percent \\
\hline $20-30$ years & 4 & 6.67 \\
$31-40$ years & 19 & 31.67 \\
$41-50$ years & 22 & 36.67 \\
$51-60$ years & 13 & 21.67 \\
61 above & 2 & 3.33 \\
\hline Total & 60 & 100.00 \\
\hline
\end{tabular}

$\mathrm{N}=60$. Source: fieldwork conducted in the lowland area.

Table 5.5 shows the age distribution in our study area, where the youngest head of household was 25 years old, and the oldest was 63. The highest percentage of respondents (36.67\%) were aged 41-50, followed those aged 31-40, with $31.67 \%$. As these age groups combined for the majority of all respondents, and are considered to be in a productive phase, they have an opportunity to develop not just their own welfare levels, but raise the welfare levels of their communities as a whole.

The level of welfare in a household is affected by the number of its members. The family planning that has been encouraged by the government, meant to increase family welfare, did not appear to be successful in the lowland area.

Table 5.6: Number of family members per household.

\begin{tabular}{lrr}
\hline Family members per household & No. of respondents & Percent \\
\hline 2 people & 5 & 8.33 \\
3 people & 15 & 25.00 \\
4 people & 15 & 25.00 \\
5 people & 23 & 38.33 \\
6 people & 2 & 3.33 \\
\hline Total & 60 & 100.00 \\
\hline
\end{tabular}

$\mathrm{N}=60$. Source: fieldwork conducted in the lowland area.

The highest percentage of households (38.33\%) comprised five family members with two parents and three children (Table 5.6). Meanwhile, households consisting of three (one child and two parents) and four family members (two children and two parents) each accounted for $25 \%$. 
These data indicate that the respondents were still in a vulnerable condition because of their need to cover higher expenditures, especially when low education levels were still inherent in the communities.

\subsection{Microfinance Institutions in the Lowland Area of Kraton Subdistrict}

The role of microfinance in bridging the gap between clients and financial institutions is considered an effective method of alleviating poverty (Hamada 2010; Imai and Azam 2010). Both formal and informal MFIs in the research area provided various financial services (Table 5.7). The formal microfinance institutions' systems referred to their legal licenses and administration from the government, while the systems of the informal microfinance institutions were designed by the community members without control and regulation from the government.

Table 5.7: Microfinance institutions.

\begin{tabular}{|c|c|c|c|c|c|c|}
\hline \multirow{3}{*}{ Types of MFIs } & \multicolumn{2}{|c|}{ Total Members } & \multirow{3}{*}{$\begin{array}{r}\text { Employees } \\
\text { (People) }\end{array}$} & \multirow{3}{*}{$\begin{array}{r}\text { Assets } \\
\text { Rp (000) }\end{array}$} & \multicolumn{2}{|c|}{ Volume of business } \\
\hline & \multirow{2}{*}{ Male } & \multirow{2}{*}{ Female } & & & 2009 & 2010 \\
\hline & & & & & Rp (000) & Rp (000) \\
\hline \multicolumn{7}{|c|}{ Koperasi Unit Desa Pertanian: } \\
\hline Hikmah & 853 & 568 & 3 & 918,726 & 20,100 & 10,050 \\
\hline Tani Raharjo & 1,246 & 831 & 5 & 192,284 & 23,200 & 11,600 \\
\hline \multicolumn{7}{|l|}{ Koppontren: } \\
\hline Esa Jaya & - & - & - & - & - & - \\
\hline Al Taqwa & 12 & 8 & - & 200 & - & - \\
\hline Puri Syamsul Arifin & 38 & 42 & - & 6,005 & 4,125 & 2,120 \\
\hline Kramat & 1,259 & 376 & 5 & 781,561 & 658,450 & 329,225 \\
\hline Sidogiri & 148 & 257 & 419 & $20,097,552$ & $19,290,400$ & $11,498,408$ \\
\hline \multicolumn{7}{|l|}{ Koperasi Karyawan: } \\
\hline Trendy Mandiri & - & - & - & - & - & - \\
\hline Mandiri KMI & 78 & 18 & 4 & 465,072 & 490,929 & 442,198 \\
\hline Grand Handa Indonesia & 26 & 61 & - & 130,339 & 186,250 & 186,250 \\
\hline \multicolumn{7}{|l|}{ Koperasi Serba Usaha: } \\
\hline Puspita & 31 & 20 & - & 68,410 & - & - \\
\hline Mikro Mitra Mina & 337 & 55 & 7 & $5,058,746$ & $2,875,900$ & $2,875,900$ \\
\hline Koperasi & & & & & & \\
\hline \multicolumn{7}{|l|}{ Pinjam: } \\
\hline Maju Bersama & 135 & 90 & 6 & $4,174,245$ & $3,117,250$ & $3,117,250$ \\
\hline \multicolumn{7}{|l|}{ Koperasi Wanita: } \\
\hline LailatulQodar-Sidogiri & - & 25 & - & - & - & 51,500 \\
\hline SunanBonang- & & & & - & - & \\
\hline Bendungan & & 25 & & & & 35,600 \\
\hline MelatiDesa-Plinggisan & - & 25 & - & - & - & 29,000 \\
\hline PKK Kartini-Pukul & - & 106 & - & 33,009 & - & 28,782 \\
\hline Anggrek & - & - & - & - & - & 25,000 \\
\hline Muslimat Al Hidayah & - & - & - & - & - & 25,000 \\
\hline
\end{tabular}




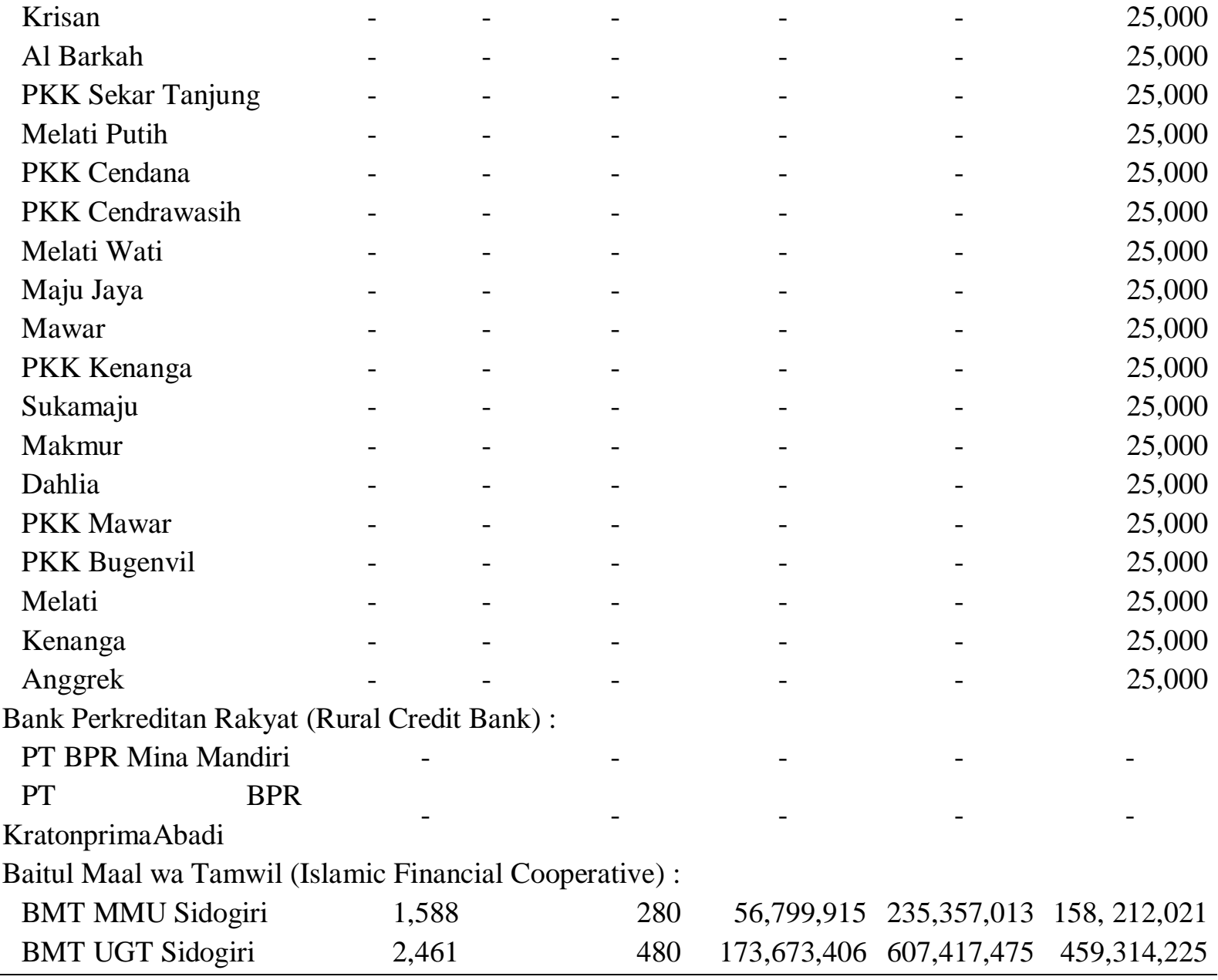

Source: Various data from the Cooperative Office of Pasuruan Regency (April 2011), with modification.

Table 5.7 shows the diversity of the MFIs in the lowland area of Kraton Subdistrict. Koperasi Unit Desa (KUD) Pertanian (the village unit cooperative) is officially endorsed by the government as the union of several agricultural cooperatives; Koppontren (Koperasi pondok pesantren) is found in pondok pesantren ${ }^{2}$ and offers financial services specifically to students; Koperasi Karyawan is a type of cooperative intended to provide financial services to factory workers; Koperasi Serba Usaha provides financial services to the local people for their businesses; Koperasi Simpan Pinjam (KSP) is supposed to provide credit and savings to communities; Koperasi Wanita is provided by the government in every province in Indonesia for the female community; Bank Perkreditan Rakyat (BPR) is a microbank supervised by Bank Indonesia at the subdistrict level; and baitul maal wat tamwil (BMT) is an Islamic microfinance cooperative based on Islamic laws for all financial transactions. The latter microfinance institution, BMT, was well-developed in this research area. Two big Islamic financial

\footnotetext{
${ }^{2}$ A pondok pesantren is an Islamic boarding school, normally controlled by religious leaders who also live in the pondok pesantren.
} 
cooperatives, in terms of performance, were BMT MMU and BMT UGT Sidogiri. The foundation behind BMT MMU, Pondok Pesantren Sidogiri, also ran several other businesses, including, for example, ones that bottled water, produced bread, and established mini markets.

Furthermore, informal microfinance systems — such as Rotating Savings and Credit Associations (ROSCA), loans from relatives, and money lenders-provided financial services to the communities. Generally, the informal MFIs were formed from community-based organizing to meet the locals' desires for financial institutions. For example, farmer communities who owned or rented land near to each other and shared one irrigation system usually formed groups called arisan kelompok tani (ROSCA for farmer groups). In the female community, they formed arisan ibu-ibu (ROSCA for female groups).

\subsubsection{Islamic Microfinance Institutions: Pondok Pesantren as the Origin of the ISLAMIC MICROFINANCE INSTITUTION}

Pondok pesantren form the oldest education system in Indonesia. Students attending one come from various regions in Indonesia or its neighboring countries, such as Malaysia and Singapore. The lowland area of Kraton Subdistrict had a large number of pondok pesantren (Table 5.8). The local people considered pondok pesantren to be more meaningful than the formal education provided by the government. The prevalence of these Islamic education institutions in the lowland area of Kraton Subdistrict is evidence of the locals' acceptance of this old education system. 
Table 5.8: Number of students in various pondok pesantren.

\begin{tabular}{|c|c|c|c|}
\hline Name of School & Village & $\begin{array}{r}\text { No. of } \\
\text { students }\end{array}$ & Caregivers (Owners) \\
\hline PP Al Falah Adirama & Sidogiri & 44 & HM Sufi Ja'far Ridwan \\
\hline PP Al Azzahidin & Sidogiri & 45 & KH KholilAbd. Karim \\
\hline PP Sidogiri & Sidogiri & 4,967 & KH Nawawi Abd. Jalil \\
\hline PP Sidogiri Annuriyah & Sidogiri & 340 & H.M Ali Muhdor \\
\hline PP Sidogiri Banat III & Sidogiri & 167 & Nyai Zuhro \\
\hline PP Sidogiri Banat V & Sidogiri & 130 & Hj. Nashihah \\
\hline PP Sunniyah Salafiyah & Sidogiri & 2,226 & Habib Taufik Assegaf \\
\hline PP al Ghofuri & Bendungan & 78 & KH Muti'urrohman \\
\hline PP Banat II Nurul Huda & Bendungan & 152 & KH. M Romli Abdullah \\
\hline PP Nurul Huda & Bendungan & 445 & KH. Abd. Hayyi \\
\hline PP Roudlotul Hikmah & Bendungan & 470 & KH. M Salim Muh. \\
\hline PP MiftahulUlum & Bendungan & 165 & Ust. Masykur Baihaqi \\
\hline PP At Taqwa & Cabean Mulyorejo & 278 & KH Ali Bahruddin \\
\hline PP BindoroSaut & Banyupahit & 165 & Ust. Mashkur Baihaqi \\
\hline PP Darul Karomah & Keramat Gerongan & 399 & KH Nur Salim \\
\hline PP Darul Khoirot & Bejawan Gerongan & 288 & KH Ma'shumhasyim \\
\hline PP Kramat & Keramat, Gerongan & 73 & KH Abd. Karim Thoyyib \\
\hline PP Darunnur & Rukem Sungi Kulon & 223 & KH Nur Sulaiman \\
\hline PP Miftahul Falah & Selotambak & 310 & H. A Yazid Bastomi \\
\hline PP Roudlotul Hadi & Selotambak & 130 & K Khannan Syuyut \\
\hline PP Miftahul Huda & Kebotohan & 240 & H Miftahul Huda \\
\hline PP Miftahul Ulum & Sukodan & 165 & Ust. Masykur baihaqi \\
\hline PP Nurul Huda & Rejosari & 154 & H. Abbas Sahrowi \\
\hline PP Sabilul Muttaqin & Karanganyar & 170 & KH Abd. Rohman S \\
\hline Syamsul Arifin Putri & Pukul & 164 & KH Ifdolus Sarif \\
\hline Syamsul Arifin & Pukul & 590 & KH. Syaifullah Daman \\
\hline Total students & & 12,578 & \\
\hline
\end{tabular}

Source: Direktori Pondok Pesantren 2008/2009

(http://pendis.kemenag.go.id/index.php?a=artikel\&id2 =statponpes2009) Direktorat Jenderal Pendidikan Islam, Religious Ministry of Republic of Indonesia.

The pondok pesantren were divided into three categories: salafiyyah (traditional system), which adopts curricula based on a kitab kuning ${ }^{3}$; modern, which adopts foreign curricula and languages, such as English and Arabic; and kombinasi (mixed system), which offers a mixture of the two aforementioned education systems (Effendi and Ernawati 2005).

Pondok Pesantren Sidogiri was the first foundation to create an Islamic microfinance institution in the lowland area, and served as the basis of many other institutions in the rest of Indonesia. Pondok Pesantren Sidogiri's wide influence and reputation might be the reason for the high number of respondents who graduated from pondok pesantren (Table 5.9).

\footnotetext{
${ }^{3}$ A kitab kuning is a book containing lessons in Arabic grammar, Islamic laws and teachings, concepts on Islamic finance, and scientific knowledge.
} 
Table 5.9: The informal education of the respondents.

\begin{tabular}{lrr}
\hline Informal Education & No. of respondents & Percent \\
\hline Pondok pesantren & 39 & 65.00 \\
Entrepreneurship & 5 & 8.33 \\
Skills & 1 & 1.67 \\
No informal education & 15 & 25.00 \\
\hline Total & 60 & 100.00 \\
\hline
\end{tabular}

$\mathrm{N}=60$. Source: fieldwork conducted in the lowland area.

Table 5.9 shows that $65 \%$ of respondents received their education from pondok pesantren, whereas $25 \%$ had no informal education. These percentages suggest that the majority of the people in the lowland area had some knowledge of Islamic law and finance.

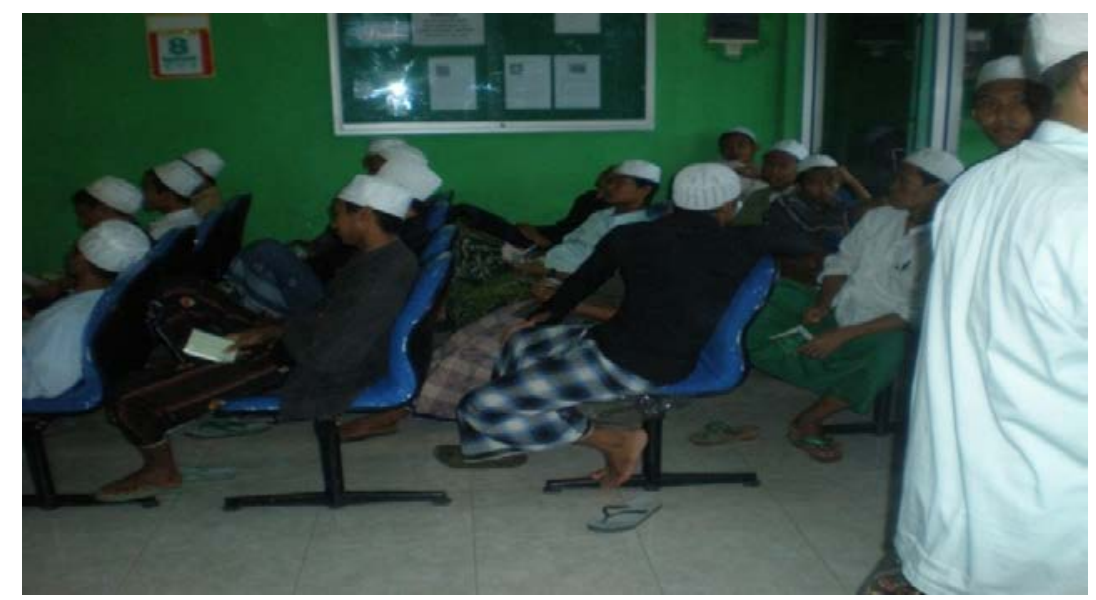

Figure 5.5: Students of Pondok Pesantren Sidogiri.

The senior students of a pondok pesantren have intensive interactions with the local communities through Islamic teachings, bakti sosial (social service), religious counseling, and other related events. Pondok Pesantren Sidogiri was the largest institution in this area with 4,967 students, and required its graduation candidates to educate others in large parts of East Java. One of the students' social services was teaching and training in the proper conduct of Islamic business, affecting the people's perceptions of Islamic microfinance in their area. At the time our research, there were three Islamic MFIs in the lowland area of Kraton Subdistrict: Koppontren, BMT UGT Sidogiri, and BMT MMU Sidogiri. BMT MMU Sidogiri was the most preferred institution by the communities because of the institution's financial performance. BMT MMU Sidogiri had 35 branches scattered throughout Pasuruan Regency and its surrounding regions in East Java.

The Islamic microfinance institutions generally used Arabic terms for the names of their schemes, such as shirkah mudharabah (a partnership between two people), shirkah musharakah (a partnership between more than two people), murabahah (purchase of items by fixed installment), ijarah (leasing of property), ba'i bi tsaman 'ajil (purchase of items using deferred 
payments), and qard al hasan (credit without interest). There were different perceptions of Islamic microfinance concepts amongst the respondents (Table 5.10).

Table 5.10: Respondents’ perceptions of IsMFIs.

\begin{tabular}{lrr}
\hline What are IsMFIs? & No. of respondents & Percent \\
\hline IsMFIs apply a profit and loss sharing system. & 21 & 35.00 \\
IsMFIs are based on Islamic law. & 33 & 55.00 \\
IsMFIs are financial institutions for Muslim & 4 & 6.67 \\
communities. & 2 & 3.33 \\
IsMFIs are based on morals/trust. & 60 & 100.00 \\
\hline Total & &
\end{tabular}

Table 5.10 shows that 55\% of respondents believed that Islamic MFIs are based on Islamic law, while 35\% believed they apply a profit and loss sharing system. These percentages indicate that most respondents understood the business schemes provided by the institutions. Additionally, $6.67 \%$ of respondents believed that Islamic MFIs are designed for Muslim communities, indicating that Islamic microfinance institutions might be adopted by non-Muslim communities even though they followed Islamic laws.

Some Islamic economists have stated that profit and loss sharing (PLS) is the core contract of Islamic financial institutions. Islamic financial institutions avoid interest or riba-based contracts.

Table 5.11: Respondents’ perceptions of PLS schemes.

\begin{tabular}{lrr}
\hline What is PLS? & No. of respondents & Percent \\
\hline $\begin{array}{l}\text { PLS encourages partnerships. } \\
\text { The profit-sharing is based on the contribution of }\end{array}$ & 5 & 11.67 \\
each person. & 16.33 \\
PLS operates without interest. & 8 & 26.67 \\
PLS is based on Islamic laws. & 23 & 38.33 \\
PLS operates in accordance with the principles of & & \\
fairness, balance, and convenience. & 1 & 1.67 \\
Other. & 60 & 100.00 \\
\hline Total & & \\
\hline
\end{tabular}

$\mathrm{N}=60$. Source: fieldwork conducted in the lowland area.

The highest percentage of respondents (38.33\%) believed PLS is in accordance with the principles of fairness, balance, and convenience, followed by those who believed that PLS operates without interest, and is based on Islamic laws, with $26.67 \%$ and $13.33 \%$, respectively (Table 5.11). 


\subsubsection{CONVENTIONAL MFIs: CREDIT SCHEMES FOR SEED AND FERTILIZER ACQUIREMENT}

The research area had a variety of conventional MFIs, many of which were, as a consequence of the area's characteristics, agriculture-based. These microfinance institutions generally offer credit schemes to the farmers for the purposes of acquiring fertilizer and seeds. A farmer that was considered to be credit-worthy saw the benefits of the institution because it did not require collateral, and only need to make repayments after harvesting their rice and other crops, with the revenue from the harvest.

Koperasi Wanita, which is provided by the government to empower women, was well-developed in this area. The women had opportunities to generate additional income for their family. Although the credit was usually only around Rp 1,000,000, they were still able to grow their businesses (Figure and 5.7).

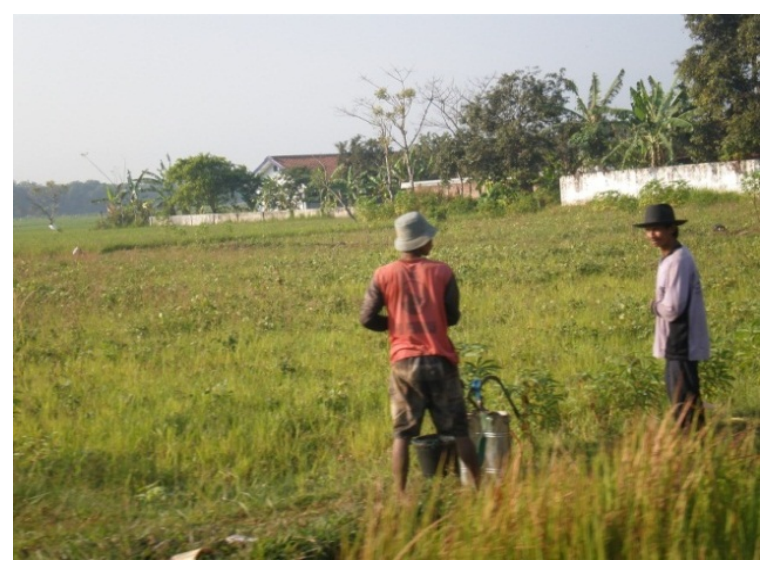

Figure 5.6: Fertilizing crops.

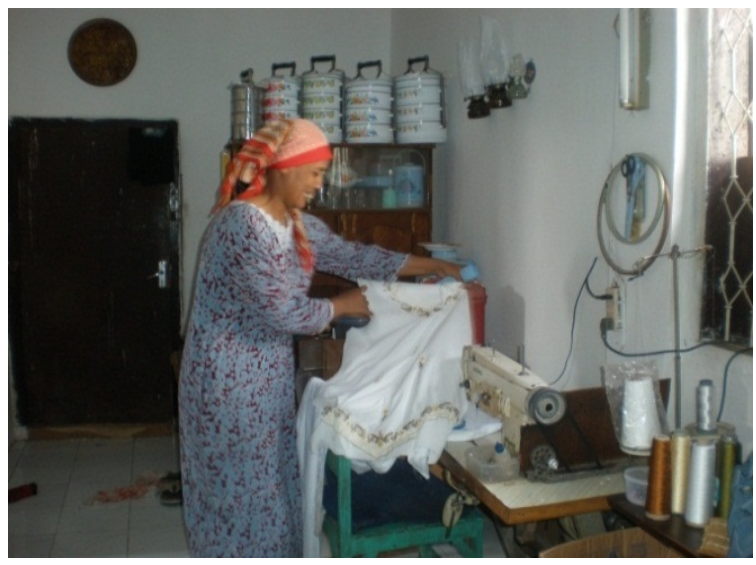

Figure 5.7: Embroidering clothes.

\subsection{Microfinance and Poverty Alleviation}

There were two types of microfinance institution in the lowland area of Kraton Subdistrict: Islamic and conventional. Both provided up to Rp 100,000,000 in credit or financing (Bank Indonesia 2003), enabling poor farmers to start cultivating the land through the provision of their financial services. The Islamic microfinance institutions provided profit-sharing schemes based on old, traditional economic systems, such as maro and mertelu ${ }^{4}$. The financial innovations of the Islamic MFIs have affected poor households' capacity for cooperation and mutual support in their fight against poverty (Quinones Jr. et al. 2000).

\footnotetext{
${ }^{4}$ Maro is when a landowner has no time to cultivate the land and so entrusts the management and cultivation of the land to others, while providing the seed, fertilizer and agricultural supplements. Traditionally, in maro, yields are divided based on an agreement between the landowners and cultivators (sometimes $50 \%$ to the landowner and $50 \%$ to the cultivators). When the landowner receives $1 / 3$ of the yield and the rice cultivator $2 / 3$, it is called mertelu.
} 
The smallholder farmers usually harvested their crops using traditional methods. They did not need to pay employees to harvest crops for them because they did so themselves or with their family members. As such, they had the additional benefit of having extra money to repay or spend on other purposes. Additionally, most people still had irregular and very low incomes. They were not able to earn more than their family expenditures without working in other economic sectors, including as factory workers, agricultural laborers, and small traders.

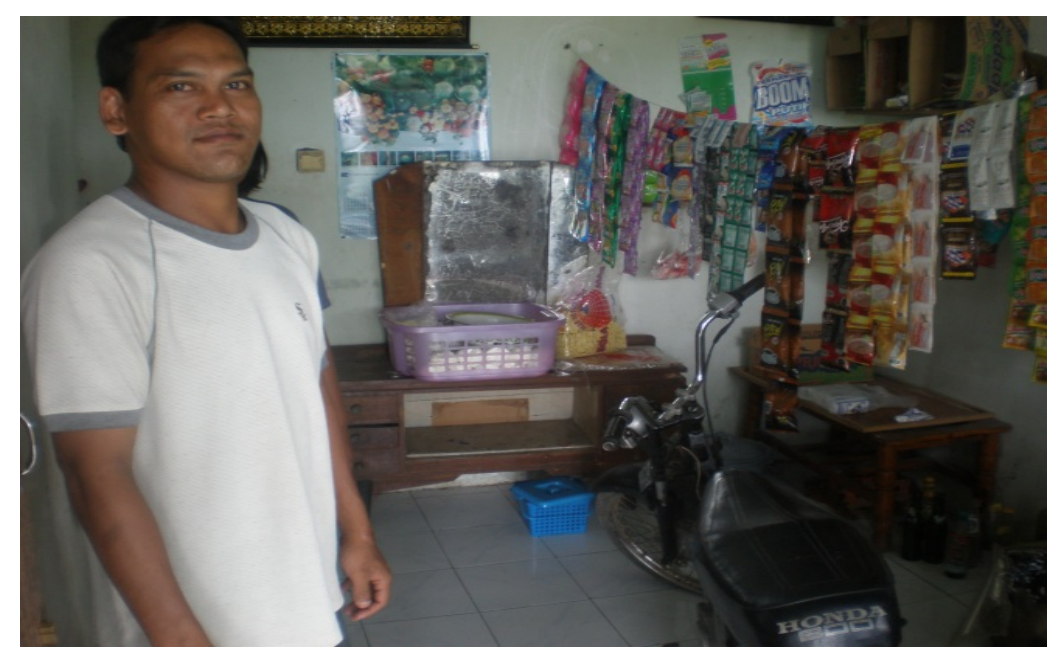

Figure 5.8: Petty trading.

Household interviews regarding incomes and expenditures are shown in Table 5.12.

Table 5.12: Monthly household income and expenditure.

\begin{tabular}{lrr}
\hline Indicators & No. of respondents & Percent \\
\hline Income per month (Rupiahs): & 2 & \\
250,001-500,000 & 2 & 3.33 \\
500,001-750,000 & 4 & 6.33 \\
$750,001-1,000,000$ & 8 & 13.33 \\
1,000,001-1,500,000 & 6 & 10.00 \\
1,500,001-2,000,000 & 30 & 50.00 \\
2000,001-5,000,000 & 8 & 13.33 \\
$>$ 5,000,000 & & \\
Expenditure per month (Rupiahs): & 0 & 0.00 \\
250,000 or less & 5 & 8.33 \\
250,001-500,000 & 11 & 18.33 \\
$500,001-750,000$ & 11 & 18.33 \\
$750,001-1,000,000$ & 14 & 23.33 \\
$1,000,001-1,500,000$ & 9 & 15.00 \\
$1,500,001-2,000,000$ & 8 & 13.33 \\
$2,000,001-5,000,000$ & 2 & 3.33 \\
$>$ 5,000,000 & & \\
\hline
\end{tabular}

$\mathrm{N}=60$. Source: fieldwork conducted in the lowland area. 
Fifty percent of respondents had incomes of Rp 2,000,001-5,000,000, by far the highest percentage. The respondents who had monthly incomes of Rp 1,000,001-1,500,000 accounted for $13.33 \%$, while those who earned $\mathrm{Rp} 750,001-1,000,000$ accounted for $6.67 \%$. The Islamic microfinance institutions provided soft loans to those with low incomes, in particular. The loans ranged from $\mathrm{Rp} 100,000$ to $\mathrm{Rp} 500,000$ for two months with weekly installment payments. Lerman (2008) found that the government's poverty-reduction program, intended for people with low incomes, may increase the farmers' benefits by giving additional land to them, allowing the land market to develop.

Concerning monthly expenditures, $8.33 \%$ of respondents had monthly expenditures of Rp 250,001-500,000, while $18.33 \%$ of respondents spent Rp 500,001-750,000 and Rp 750,0011,000,000. The highest percentage of respondents (23.33\%) had monthly expenditures of Rp 1,000,001-1,500,000. These data indicate that the respondents still had low purchasing power, despite trying to balance their income and expenditures.

Table 5.13: Cross tabulation between monthly household income and expenditure.

\begin{tabular}{|c|c|c|c|c|c|c|c|}
\hline \multirow[b]{2}{*}{$\begin{array}{l}\text { Main and side } \\
\text { income (Rupiahs) }\end{array}$} & \multicolumn{7}{|c|}{ Monthly expenditure (000 Rupiahs) } \\
\hline & $\begin{array}{l}250,1- \\
500,\end{array}$ & $\begin{array}{l}\text { 500,1- } \\
750,\end{array}$ & $\begin{array}{l}750,1- \\
1000,\end{array}$ & $\begin{array}{l}1,000,1- \\
1,500,\end{array}$ & $\begin{array}{l}1,500,1- \\
2,000,\end{array}$ & $\begin{array}{l}2,000,1- \\
5,000,\end{array}$ & $>5,000$ \\
\hline $250,001-500,000$ & 0 & 1 & 0 & 1 & 0 & 0 & 0 \\
\hline $500,001-750,000$ & 2 & 0 & 0 & 0 & 0 & 0 & 0 \\
\hline $750,001-1000,000$ & 1 & 3 & 0 & 0 & 0 & 0 & 0 \\
\hline $1,000,001-1,500,000$ & 2 & 3 & 1 & 2 & 0 & 0 & 0 \\
\hline $1,500,001-2,000,000$ & 0 & 2 & 1 & 2 & 1 & 0 & 0 \\
\hline $2,000,001-5,000,000$ & 0 & 1 & 7 & 9 & 7 & 5 & 1 \\
\hline$>5,000,000$ & 0 & 1 & 2 & 0 & 1 & 3 & 1 \\
\hline Total people & 5 & 11 & 11 & 14 & 9 & 8 & 2 \\
\hline
\end{tabular}

$\mathrm{N}=60$. Source: fieldwork conducted in the lowland area.

Table 5.13 shows that household respondents whose incomes ranged from $\mathrm{Rp} 2,000,000$ 5,000,000 had various monthly expenditures: nine people (15\%) spent Rp 1,000,001-Rp 1,500,000, while seven people each (11.67\%) had monthly expenditures of Rp 750,0001,000,000 and Rp 1,500,000-2,000,000. These data indicate that these household respondents still had low purchasing power, even though they earned relatively enough income. Table 5.13 also shows that one respondent who earned more than $\mathrm{Rp} 5,000,000$ had a monthly expenditure of Rp 500,001-750,000, while two others had expenditures of Rp 750,001-1,000,000, indicating that a small minority of respondents had high purchasing power. In contrast, two of the 
interviewed households (3.33\%) lived in severe poverty, with incomes of Rp 250,001-500,000 while requiring more than Rp 500,000 for their monthly expenditures

Table 5.14: Cross tabulation between family size and income.

\begin{tabular}{lrrrrr}
\hline Cross tabulation & \multicolumn{5}{c}{ Number of family members } \\
\hline Main and side income (Rupiahs) & 2 & 3 & 4 & 5 & 6 \\
\cline { 2 - 6 } $250,001-500,000$ & 1 & 0 & 0 & 1 & 0 \\
$500,001-750,000$ & 0 & 1 & 1 & 0 & 0 \\
$750,001-1,000,000$ & 1 & 3 & 0 & 0 & 0 \\
$1,000,001-1,500,000$ & 0 & 3 & 1 & 3 & 1 \\
$1,500,001-2,000,000$ & 0 & 3 & 1 & 2 & 0 \\
$2,000,001-5,000,000$ & 1 & 5 & 11 & 13 & 0 \\
$>5,000,000$ & 2 & 0 & 1 & 4 & 1 \\
\hline Total & 5 & 15 & 15 & 23 & 2 \\
\hline
\end{tabular}

$\mathrm{N}=60$. Source: fieldwork conducted in the lowland area.

Table 5.14 shows that 13 (21.67\%) respondents whose incomes ranged from $\mathrm{Rp}$ 2,000,001 to Rp 5,000,000 had five family members, and those earning Rp 2,000,000-5,000,000 accounted for 18.33\%, with 11 people. These data indicate that larger family sizes resulted in higher expenditures. Additionally, three (5\%) households with five members earned Rp 1,000,001$1,500,000$, while one household with five members as well earned Rp 250,001-500,000. These percentages indicate that in order to cover family expenditures for a household with five members, the respondents still required additional financial resources. On the other hand, two households earned more than Rp 5,000,000 while having only two family members, and one household with two family members earned Rp 2,000,001-5,000,000, suggesting that some people in the lowland area had both purchasing power and an ability to save money. 
Box 5.1: Microfinance and poverty alleviation

We conducted in-depth interviews to collect information on the influence of microfinance on poverty alleviation. Clients of Islamic and conventional MFIs were interviewed.

The first respondent was $\mathrm{H}$ Ansori, who started an agricultural production business in 1980 . He was a customer of an Islamic microfinance institution since 1997, and received financing multiple times. The last time he received financing, the amount was $R p 7,000,000$. Because of his long membership, the IsMFI trusted him, and thus was not worried about giving him a large amount of financing. He was interested in the financing schemes because the administration process of the institution was simple. Based on his experiences, institutions would not charge a penalty when clients had problems in paying their installments. Regarding poverty, he said, "I could buy whatever I wanted after receiving financing from the Islamic microfinance institution, and I saw an increase of around $40 \%$ in net profit."

The second client, Mulyono, started a small bread-selling business in 1985. He started his business after a friend invited him to take part in selling bread, and initially worked only three hours a day. He received $\mathrm{Rp} 700,000$ in financing from an Islamic microfinance institution. Discussing the benefits of his institution, he said, "I had net profits of $15 \%$ per day. This has improved the scale of my business."

The third respondent was Ahmad, a man who received $\mathrm{Rp} 2,000,000$ worth of credit from a conventional microfinance institution. His photocopying business opened in 2002. He said that his business had good prospects because he was the only person who had a copy business. On how microfinance affects poverty, he said, "My business is already well-known in this area. It affected my business's profits and allowed me to apply for more credit to purchase a motorcycle."

Samari, the fourth client, had five family members, and had been receiving credit from a conventional microfinance institution since 1978. His institution had great trust him, and he often invited his neighbors to join it. He received a loan of $\mathrm{Rp} \mathrm{1,000,000.} \mathrm{The} \mathrm{institution} \mathrm{charged} \mathrm{him}$ $1.5 \%$ interest for a year, during which he repaid the loan. Discussing his welfare after joining the microfinance institution, he said, "My business increased its profits after I received credit from the microfinance institution. I could build a new house, although the performance of my business fluctuated."

In general, microfinance institutions played a significant role in poverty alleviation in the lowland area, since the income per capita of the employees of the businesses, as well as the scale of the businesses, increased.

In general, the respondents' businesses saw increases in net profits and other benefits after they had joined a microfinance institution, such as increases in income from crop and off-farm activities, cultivated agricultural area, and capital to spend on durable assets and agricultural inputs (Morris and Barnes 2005). The soft loans and qard al hasan provided by the Islamic microfinance institutions gave the clients-particularly those with low incomes-a number of benefits. The development of the microfinance institutions was influenced by the Islamic culture 
in the region, especially the presence of pondok pesantren, and institutions that provided social assistance, such as housing renovations for the poor and aid after natural disasters, had positively attracted the public's attention. This social assistance from the institutions also positively affected poverty alleviation in our research area.

Theoretically, the microfinance institutions did not require collateral from their clients when they applied for credit schemes. However, when it was costly to monitor clients' repayment and installment records, collateral was required.

\subsection{Microfinance and Environmental Awareness in the Lowland Area; Annual Floods and Lack of Knowledge of the Local People}

Recently, the occurrence of environmentally-friendly business practices has increased. Some regulators pressure the owners of small and medium-sized enterprises (SMEs) to improve their environmental management strategies and practices. Since the microfinance institutions have clients until the grassroots level, they can play a significant role in environmental awareness. Some experts have claimed that MFIs could play a role in fostering pro-environmental behaviors among their micro entrepreneur clients (Allet 2012).

The socioeconomic conditions of the people in our research area affected the quality of their surrounding environment. Access to drinking water and the availability of permanent toilet and bathroom facilities at home were some indicators of good sanitation. Polluted water causes diseases and contaminates larger ecosystems, along with the overuse of agricultural inputs, which pollute fields (Shortall 2009).

During data collection, it appeared that people still had a limited awareness of their environment. Traditional latrines over rivers were easily found in the area, even near inter-regency roads, and water from these rivers was used for bathing and washing clothes and household furniture.

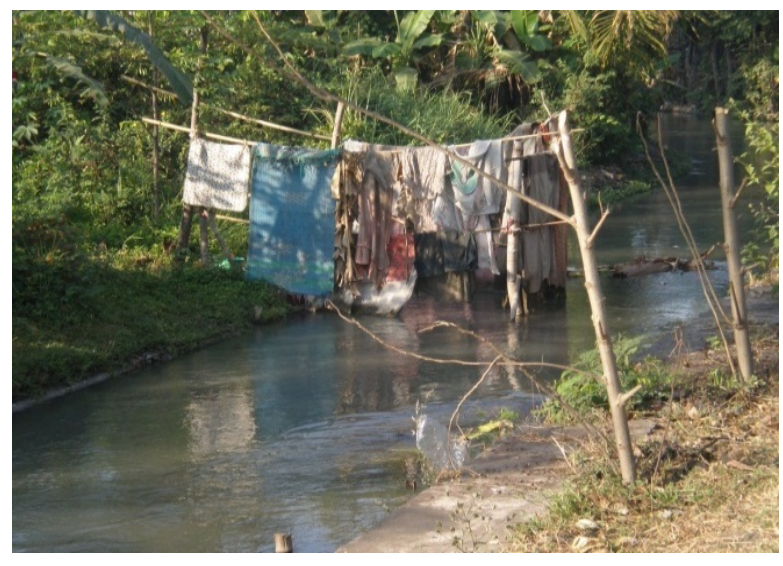

Figure 5.9: Traditional latrine over a river.

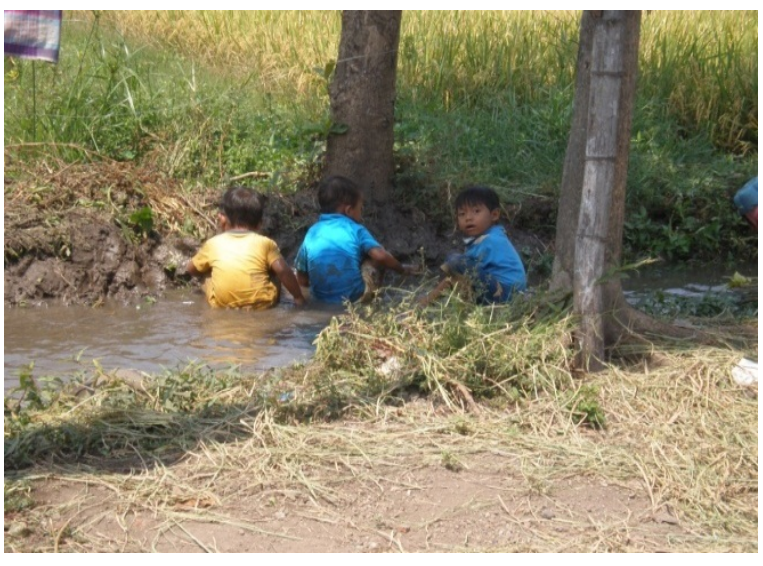

Figure 5.10: Children playing in dirty water. 
Figures 5.9 and 5.10 are evidence of the locals' lack of environmental awareness. All routine activities, which included playing and disposing of garbage, as well as bathing and washing, were based on the rivers. One reason is because they were unable to build permanent latrines and bathroom facilities in their homes, or public facilities for defecating. They were used to "the simple way" and cared less about the health risks. The lowland area had many rivers, which helped increase the farmers' agricultural production. The rivers were also a problem, however, as the local people were accustomed to throwing rubbish into them and neglecting the irrigation channels. Annual floods occurred in this area, sometimes because of the careless habits of the locals.

The occurrence of annual floods, for which the local government and communities have not yet found the best solution, might be a big problem in the future, particularly for the villages surrounding the rivers. Floods negatively impact the health of the people living near rivers. Even though some local people put sandbags on the riverbanks as a means of preventing flooding, this is not an adequate long-term solution. The local government should ally with the communities to create better infrastructure around the rivers. Furthermore, farmers in our research area preferred to burn their crop waste rather than use it for another purpose, such as cattle feed or raw materials in paper production. This is possibly because they were not aware of these other uses for their waste. Lack of training in environmental issues might be the main cause of the low environmental awareness in this area.

Table 5.15: Training on environmental issues provided by the MFIs.

\begin{tabular}{|c|c|c|c|}
\hline $\begin{array}{l}\text { Do MFIs provide } \\
\text { environmental issues? }\end{array}$ & training on & No. of respondents & Percent \\
\hline Yes & & 10 & 16.67 \\
\hline No & & 42 & 70.00 \\
\hline Don't know & & 8 & 13.33 \\
\hline Total & & 60 & 100.00 \\
\hline
\end{tabular}

$\mathrm{N}=60$. Source: fieldwork conducted in the lowland area.

Seventy percent of respondents reported that they did not receive training on environmental issues, and 13.33\% did not know whether MFIs provide training on environmental matters (Table 5.15). Contrarily, only $16.67 \%$ of respondents reported receiving training. These percentages indicate that lack of training and knowledge from the MFIs in this area has affected the environmental awareness of the people significantly. According to Lal (2010), however, MFIs provide a variety of training opportunities to their clients as a prerequisite for obtaining loans, providing an existing infrastructure for imparting environmental awareness and specific 
management information. Still, the significant environmental benefits are possible since environmental awareness will be introduced into the community. Spreading environmental awareness amongst small entrepreneurs might have a large social impact, since the community will influence other sectors of the economy. MFIs are very uniquely placed to promote environmental awareness by identifying the areas of greatest environmental concern and having environmental management information available to clients.

Located in a fertile area, most people in our research site did not lack water during the planting season. Their crops had better yields than the coastal area of Nguling Subdistrict and the upland area of Purwosari, encouraging the farmers to grow rice three times a year instead of twice a year. On the other hand, their geographical location also brought with it the risk of floods, sometimes affecting the agricultural production. Many people were unable to work after contracting diseases brought on by the floods. If the MFIs provided social programs to help alleviate these problems, agricultural production as well as welfare may be less affected by natural disasters such as the annual floods in this area.

Table 5.16: Social programs provided by the MFIs.

\begin{tabular}{lrr}
\hline Do MFIs provide social programs? & No. of respondents & Percent \\
\hline Yes & 11 & 18.33 \\
No & 44 & 73.33 \\
Not know & 5 & 8.33 \\
\hline Total & 60 & 100.00 \\
\hline
\end{tabular}

$\mathrm{N}=60$. Source: fieldwork conducted in the lowland area.

Table 5.16 shows that $73.33 \%$ of the clients reported that MFIs did not provide social programs, while $8.33 \%$ of respondents did not know whether the MFIs provide such programs. Only $18.33 \%$ of respondents reported that the MFIs provide social programs to the communities. These data suggest that while the MFIs provided social programs related to environmental issues, these programs were only conducted in certain parts of the lowland area. Although most of the respondents said that the MFIs did not provide social programs, they still had a willingness to protect the environment surrounding their houses, however.

Table 5.17: Problems faced by the respondents.

\begin{tabular}{lrr}
\hline Do you perceive any problems in No. of respondents & Percent \\
maintaining the environment? & 3 & \\
\hline Yes & 57 & 5.00 \\
No & 60 & 100.00 \\
\hline Total & & \\
\hline
\end{tabular}

$\mathrm{N}=60$. Source: fieldwork conducted in the lowland area. 
Table 5.17 shows that 95\% of respondents did perceive any problems in maintaining the environment. Only $5 \%$ of respondents had problems in maintaining the environment. In spite of this, the low level of knowledge and lack of training on environmental issues might be the causes of their inability to improve their environmental awareness. Akca, Sayili, and Yilmazcoban (2007) point out that rural people require greater information on technical terms, adding that the private sector, and both governmental and non-governmental organizations should organize conferences, seminars, and meetings on environmental issues, while supporting the idea of rural people joining environmental organizations.

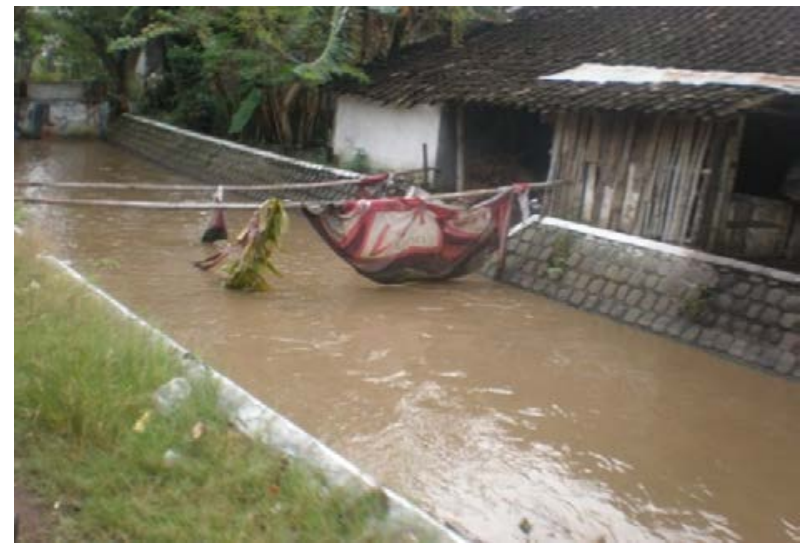

Figure: 5.11: Traditional latrine.

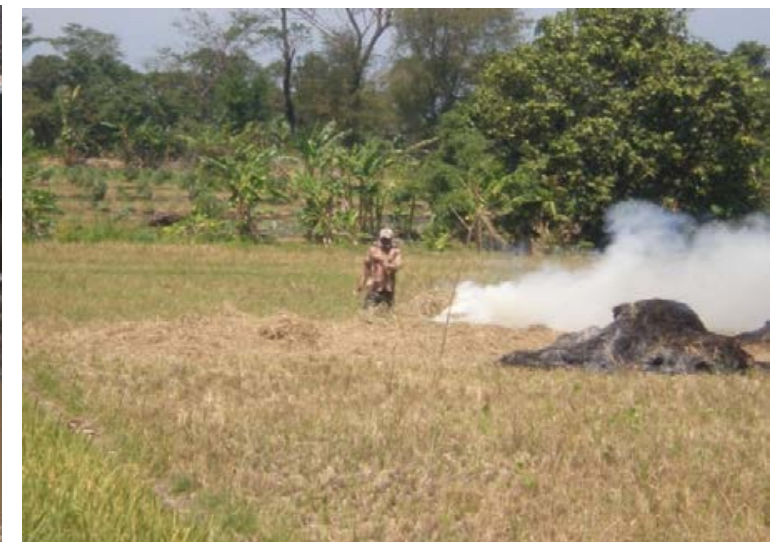

Figure 5.12: Burning rice plant waste.

Figures 5.11 and 5.12 show some of the environmental problems in the lowland area of Kraton Subdistrict. The local people considered these practices to be in compliance with environmental preservation. When asked about the environmental damage in the area, most of the respondents claimed to have initiatives to improve the environment. However, the efforts to preserve the environment were only in accordance with their own abilities.

Table 5.18: Reaction of the community to environmental damage.

\begin{tabular}{lrrr}
\hline $\begin{array}{l}\text { How would you react to damage to your } \\
\text { environment? }\end{array}$ & No. of respondents & Percent \\
\hline $\begin{array}{l}\text { I will report to the village leader or village } \\
\text { organizations. }\end{array}$ & 10 & 16.67 \\
$\begin{array}{l}\text { I will reduce the environmental damages to the best } \\
\text { of my ability. }\end{array}$ & 26 & 43.33 \\
$\begin{array}{l}\text { I will invite my neighbor(s) to help me improve the } \\
\text { environment's condition. }\end{array}$ & 23 & 38.33 \\
Other. & 1 & 1.67 \\
\hline Total & 60 & 100.00 \\
\hline
\end{tabular}

$\mathrm{N}=60$. Source: fieldwork conducted in the lowland area. 
Table 5.18 shows that $43.33 \%$ of respondents would try to reduce the environmental damage to the best of their ability. A slightly smaller number of respondents (38.33\%) said they would invite their neighbor(s) to assist them in improving the environment's condition. Meanwhile, $16.67 \%$ of respondents would report to the village officials.

Box 5.2: Microfinance institution clients on environmental issues.

To get a perspective on the effect of MFIs on environmental awareness in the lowland area of Kraton Subdistrict, we interviewed some of their clients. The first client was Mansur, who started a business selling agricultural products in 1996. He received financing worth $R p$ 1,500,000 from an Islamic microfinance institution. Regarding environmental awareness, he said, "As far as I know, my business does not affect the environment. However, I will invite my neighbor(s) to help me improve the environment's condition if it is damaged."

The second client we interviewed was Sa'roni, a member of a conventional microfinance institution. He had operated a small business making furniture from wood since 1991. He received Rp 1,500,000 in credit from his institution as additional capital for his business. On dealing with environmental damage, he said, "I cut down forest trees for my business, but I am sure that there has been no negative impact on forest degradation. Nonetheless, I would avoid the negative effects of my business to the best of my knowledge."

The third client, H. Syafi'i, received financing worth $\mathrm{Rp}$ 2,000,000 from an Islamic microfinance institution. He relied on his crops for his routine income. Discussing issues with environmental awareness, he said, "My business activities have a low impact on environmental damage, because they have been passed down from my ancestors for generations."

Minarsih, the fourth respondent, started a small trading business in 1995 and had been growing crops since 2000. Her husband was a community leader and often invited neighbors to work together in reducing environmental damage. She shared her experience regarding the environmental damage with us, saying, "My business does not have hazardous waste. When the business produces litter, it can be resold again. But, I am most concerned with environmental awareness, as well as increasing welfare."

Generally, the smallholder farmers and beginner entrepreneurs in the lowland area had favorable attitudes toward the environment, as evidenced by their actions to improve the environmental impact of their economic activities. However, they tried to improve the environment to the best of their abilities, only. It seems more likely that they were either unaware of the environmental impact of their businesses or that they did not know what they could do to improve the environment in their own enterprise (Gadenne, Kennedy, and McKeiver 2009).

Irregular income, low skill, and limited knowledge on how to maintain the environment were inherent in this research site. 


\section{Coastal Area}

\subsection{Overview of Research Area}

The majority of the target respondents were located in the coastal area of Nguling Subdistrict. We chose this location based on its potential in Islamic microfinance institutional development, as described to us by the leaders of the microfinance institutions. Situated in the northeast of Pasuruan Regency (7.30'-8.30'S and 112.30'-113.30'E, 0-100 m a.s.l.), Nguling Subdistrict's waters fall under Sidoarjo Regency's jurisdiction, even though Sidoarjo lies on the opposite end of Pasuruan. To the east is Probolinggo Regency, while in the west and southwest are Lekok and Grati Subdistricts, respectively. The area has a similar climate to the other areas in Pasuruan Regency, with only two seasons: rainy and dry, the former lasting from October to April and the latter May to September.

Table 6.1: Number of rainy days, monthly rainfall, and daily average of rainfall.

\begin{tabular}{llrrr}
\hline No & Months & Rainy days & $\begin{array}{r}\text { Rainfall } \\
(\mathrm{mm})\end{array}$ & $\begin{array}{r}\text { Average } \\
(\mathrm{mm} / \text { days })\end{array}$ \\
\hline 1 & January & 20 & 438 & 21.90 \\
2 & February & 19 & 411 & 21.63 \\
3 & March & 21 & 453 & 21.57 \\
4 & April & 18 & 244 & 13.56 \\
5 & May & 14 & 206 & 14.71 \\
6 & June & 8 & 187 & 23.38 \\
7 & July & 4 & 55 & 13.75 \\
8 & August & & - & \\
9 & September & 2 & 28 & 14.00 \\
10 & October & 6 & 81 & 13.50 \\
11 & November & 11 & 239 & 21.73 \\
12 & December & 13 & 234 & 18.00 \\
\hline & Total & 136 & 2576 & 18.94 \\
\hline
\end{tabular}

Source: BPS, Statistic of Pasuruan Regency, Nguling In Figures (2011), with modification.

As the southern part of the area is flat, most of the communities rely on agriculture, such as raising livestock and planting rice. Although people can grow rice and peanuts near the sea, the majority of the area's residents, particularly those in the north, which is coastal, depend on marine resources, as well as labor work for fishermen who had their own vessels and modern fishing tools. Part of the road in this research area is asphalted, while some parts need 
renovation, especially in the kampung nelayan ${ }^{5}$, where the roads are still made of clay and gravel and may become muddy during the rainy season.

The village officials in our research site had various levels of education. Ideally, the higher a village official's educational level, the better they will be at planning and managing the services they provide to the community.

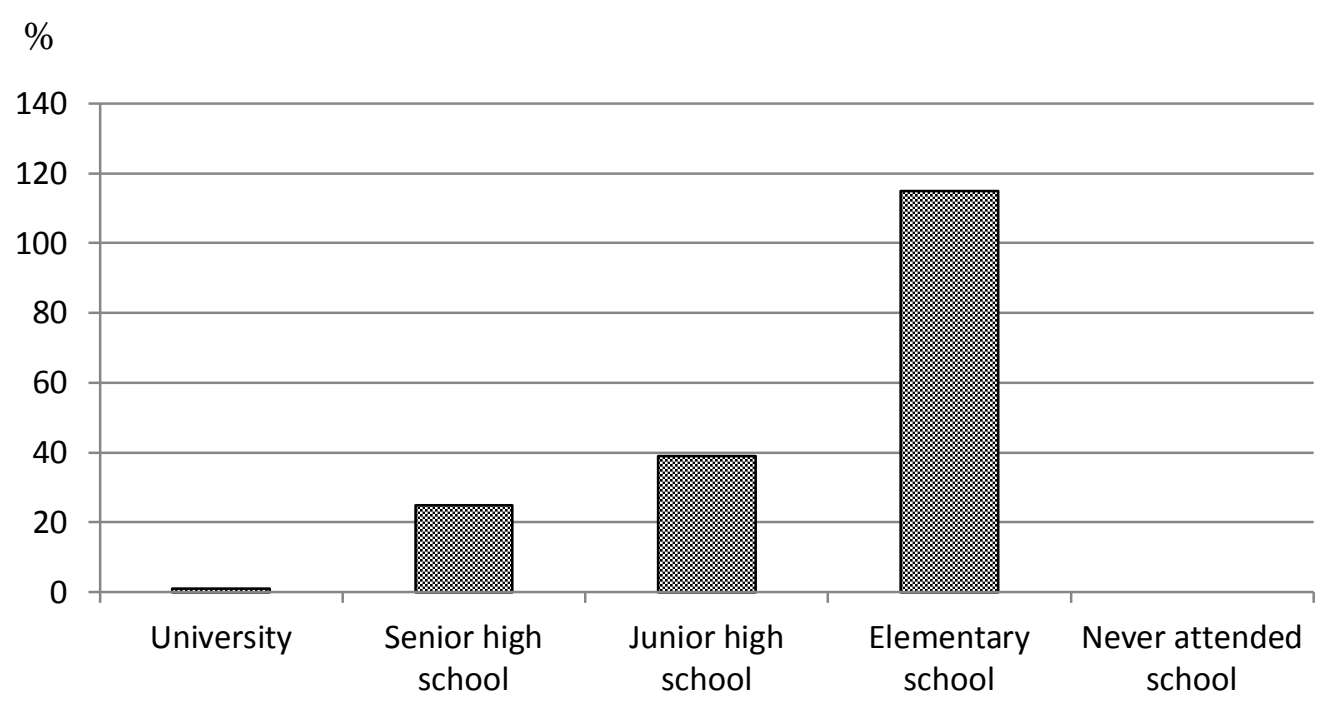

Figure 6.1: Education level of village officials in the research site. Source: BPS, Statistic of Pasuruan Regency, Nguling In Figures (2011), with modification.

The coastal fishing communities generated the majority of their income from the living resources of the adjacent sea. The local culture, social cohesion, skill, and knowledge that are acquired and passed down over generations have allowed them to subsist in this region for hundreds of years. The communities are used to working together and building social cohesion through local rules and norms regarding property and individual rights. An example custom is the prohibition on fishing when the catch is too young or small; fishermen will instead go to other coastal regions, such as Tulung Agung, Banyuwangi, Jember, and other potential fishing areas. Although there was a marine supervisory agency in the area, the communities also tried to take the initiative in protecting their natural assets in order to have sustainable resources.

Demographically, the people of this area were categorized as of productive age (Figure 6.2).

\footnotetext{
${ }^{5}$ Kampung nelayan is a seaside village whose inhabitants rely mainly on marine resources for subsistence.
} 
Female

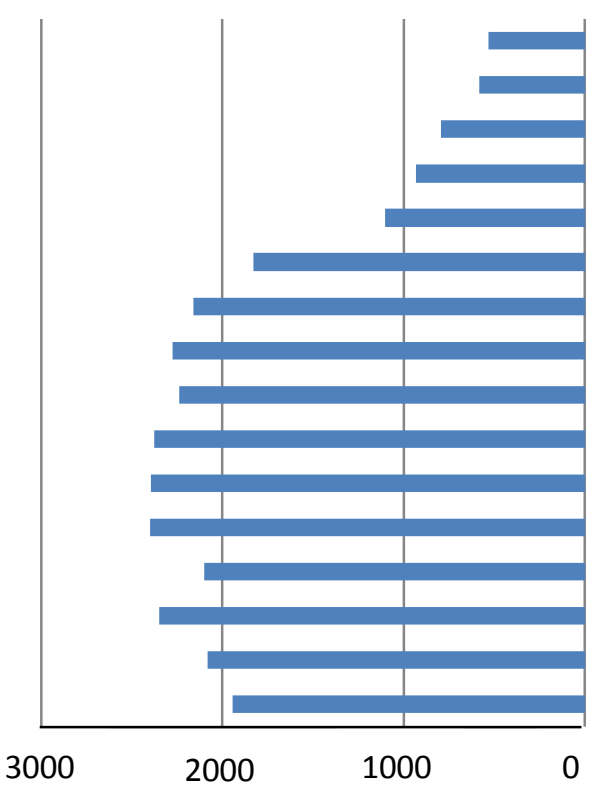

Male

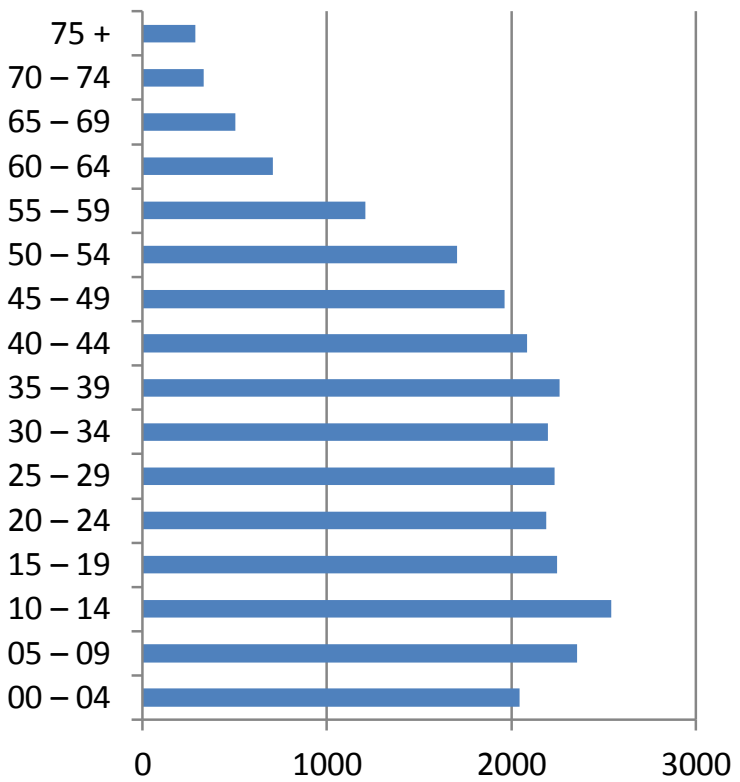

Figure 6.2: Population by age group. Source: BPS, Statistic of Pasuruan Regency, Nguling In Figures (2011), with modification.

Fishermen still used a traditional fishing craft (Figure 6.3), which takes two to five people out to sea. Fishing usually started in the evening and ended the next day in the afternoon (Figure 6.4).

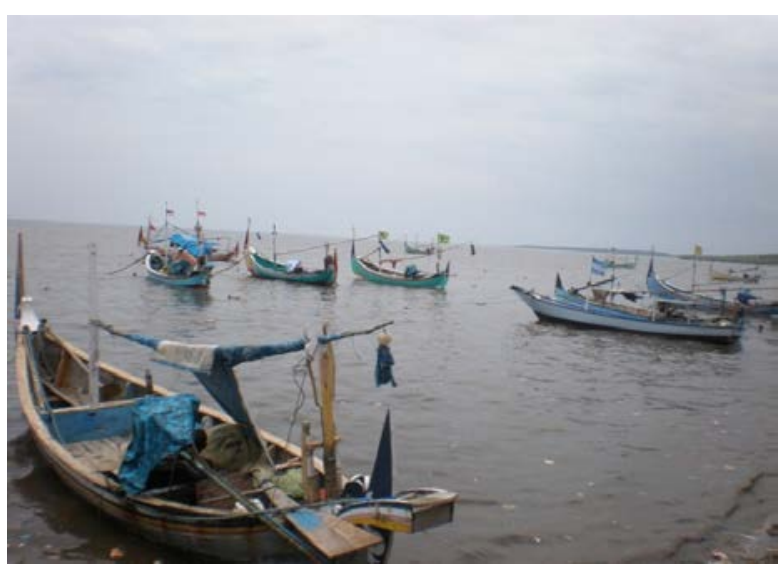

Figure 6.3: Traditional boats.

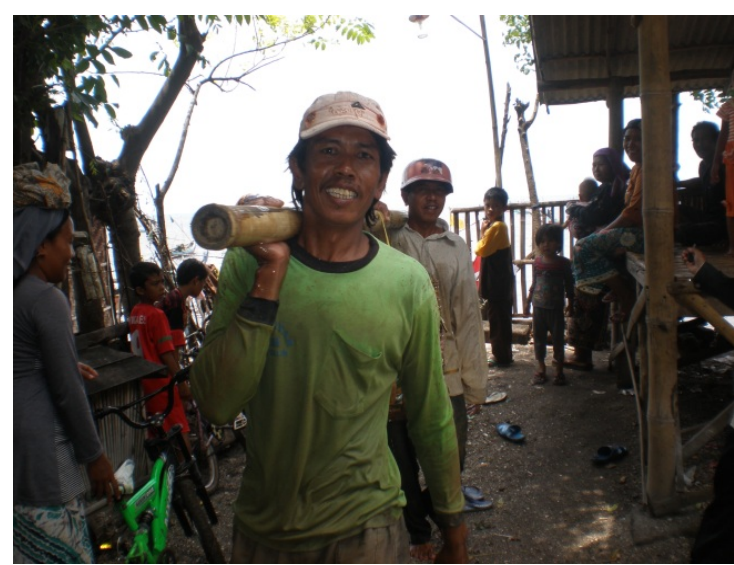

Figure 6.4: Fisherman returning.

Generally, the fishermen would sell their catch directly to the local traditional market or, occasionally, a fish market located in the kampung nelayan. If they were able sell their catch quickly enough, they would return to sea later in the day after a period of resting. These fish markets saw more customers, both local and from other regions, than the traditional markets (Figure 6.5). 


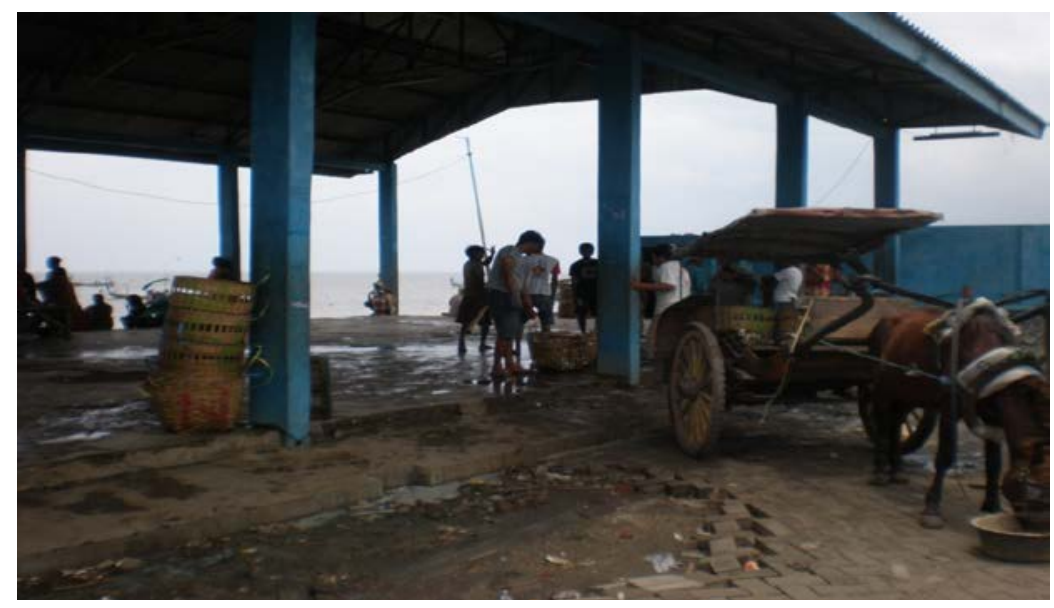

Figure 6.5: Traditional fish market.

The education level of the people in the coastal area is shown in Table 6.2.

Table 6.2: Education level of local people in research site.

\begin{tabular}{lrr}
\hline Level of schooling & No. of people & Percent \\
\hline No/some elementary school & 10,399 & 25.07 \\
Completed elementary school & 21,916 & 52.84 \\
Completed junior high school & 5,669 & 13.67 \\
Completed senior high school & 2,967 & 7.15 \\
Completed diploma program $^{6}$ & 171 & 0.41 \\
Academy/university & 318 & 0.77 \\
Master/doctoral degree & 34 & 0.08 \\
\hline Total & 41,474 & 100.00 \\
\hline
\end{tabular}

Source: BPS, Statistic of Pasuruan Regency, Nguling In Figures (2011), with modification.

The majority of people (52.84\%) in the coastal area only completed elementary school, followed by those who had no or only some elementary school (25.07\%). Just $1.26 \%$ had any education beyond senior high school, with those who completed a diploma program, academy or university, or a master or doctoral degree accounted for $0.41 \%, 0.77 \%$, and $0.08 \%$, respectively. Based on these figures, it is clear that the education system in the region, which is provided by the government, largely failed the people depending on it.

The welfare level of the local people is influenced by the natural resources obtained from the sea. However, during certain periods of the year, limited fish populations prevent the fishermen from going out to sea, affecting their income and, consequently, welfare. Although the government conducts many poverty-related programs, the percentage of poor people in this coastal area is still high (Table 6.3).

\footnotetext{
${ }^{6}$ A diploma program takes one to three years to complete, and is more vocational than a university program. The certificate obtained is equivalent to an associate degree.
} 
Table 6.3: Level of welfare in the research site.

\begin{tabular}{lrr}
\hline Level of welfare & No. of people & Percent \\
\hline Pre-prosperous (very poor) & 2,974 & 18.71 \\
Welfare level I (poor) & 5,361 & 33.73 \\
Welfare level II & 5,205 & 32.75 \\
Welfare level III & 2,064 & 12.99 \\
Welfare level III + & 288 & 1.81 \\
\hline Total & 15,892 & 100.00 \\
\hline
\end{tabular}

Source: BPS, Statistic of Pasuruan Regency, Nguling In Figures (2011), with modification.

The highest welfare percentage of all groups belonged to welfare level I (33.73\%), which is classified as poor by the Agency of National Population and Family Planning (BKKBN). These percentages suggest that the poor people of Nguling Subdistrict still need to be empowered through sustainable development provided by the government and other non-governmental organizations.

\subsection{Characteristics of Respondent Households}

The interviewed respondents in this research site are divided into three groups: clients of Islamic microfinance institutions whose financial services are based on Islamic laws; clients of conventional microfinance institutions who adopt financial services based on secular laws; and key informants who supply information and knowledge about the research site, and the development and history of both Islamic and conventional microfinance institutions in the area.

The respondents derived their income from marine resources such as fish, processed fish products like grilled fish, salted fish, and traditional canned fish of bamboo crafting. In addition, they succeeded in using the knowledge and skills acquired from their ancestors to base their economic activities around coastal businesses involving things such as producing traditional fish trawls and fish baskets made of bamboo.

Table 6.4: Economic activities of head of household.

\begin{tabular}{lrr}
\hline Main occupation & No. of respondents & Percent \\
\hline Self-employed in agriculture (fishing) & 21 & 35.00 \\
Self-employed in off-farm enterprises & 30 & 50.00 \\
Government employee & 1 & 1.67 \\
Casual/free worker & 4 & 6.67 \\
Salaried worker in non-agriculture & 4 & 6.67 \\
\hline Total & 60 & 100.00 \\
\hline
\end{tabular}

$\mathrm{N}=60$. Source: fieldwork conducted in the coastal area. 
Table 6.4 shows that a large percentage of respondents in the coastal area, 35\%, worked as fishermen. Fifty percent were self-employed in off-farm enterprises, which included grilling and boiling fish, and reselling fish purchased from the fish market or fisherman in traditional markets. With only a minority of people (15\%) not having any involvement in the fishing industry, this region was heavily dependent on, and influenced by, the fluctuations in fish populations that occurred throughout the year.

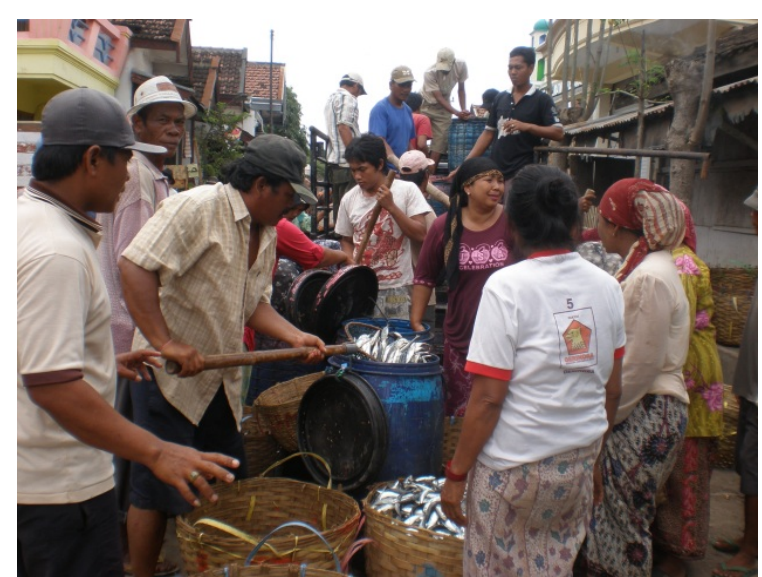

Figure 6.6: Traditional fish market.

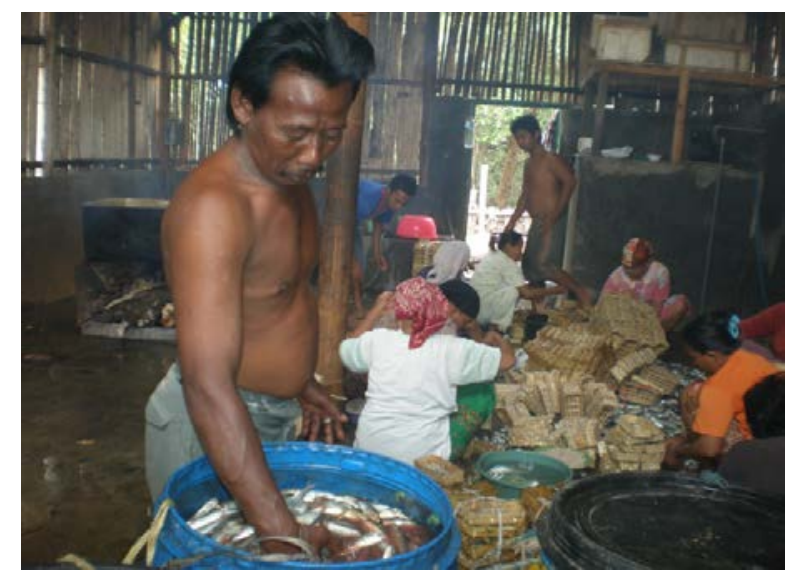

Figure 6.7: Packing fish.

Table 6.5 shows the level of education of each head of household.

Table 6.5: Education level of household's head.

\begin{tabular}{lrr}
\hline Level of formal education & No. of respondents & Percent \\
\hline Never attended school & 1 & 1.67 \\
Some elementary school & 1 & 1.67 \\
Completed elementary school & 20 & 33.33 \\
Attended junior high school & 1 & 1.67 \\
Completed junior high school & 10 & 16.67 \\
Attended senior high school & 1 & 1.67 \\
Completed senior high school & 22 & 36.67 \\
Attended academy/university & 4 & 6.77 \\
\hline Total & 60 & 100.00 \\
\hline
\end{tabular}

$\mathrm{N}=60$. Source: fieldwork conducted in the coastal area.

The highest percentage of heads of household (36.67\%) belonged to those who completed senior high school, followed by the respondents who completed elementary school, with $33.33 \%$, and those who completed junior high school. with $16.67 \%$. While these percentages are not perfectly reflective of the population as a whole, they are still consistent with our previous observation that education is a significant problem in the area. 
Table 6.6: Age of household's head.

\begin{tabular}{lrr}
\hline Age distribution & No. of respondents & Percent \\
\hline $20-30$ years & 13 & 21.67 \\
$31-40$ years & 19 & 31.67 \\
$41-50$ years & 19 & 31.67 \\
$51-60$ years & 9 & 15.00 \\
61 above & 0 & 0.00 \\
\hline Total & 60 & 100.00
\end{tabular}

$\mathrm{N}=60$. Source: fieldwork conducted in the coastal area.

Table 6.6 shows that $21.67 \%$ of respondents were aged $20-30$, while $31.67 \%$ were aged $31-40$ and another $31.67 \%$ aged 41-50. All of our respondents were capable of running their own businesses, and would often invite their family members to catch fish with them; this helped cover family expenditures and give the family members experience in fishing. The larger the families, the higher the expenditures they had to cover, possibly serving as the cause of their poverty.

Table 6.7: Number of family members per household.

\begin{tabular}{lrr}
\hline Family member of household & No. of respondents & Percent \\
\hline 2 people & 2 & 3.33 \\
3 people & 29 & 48.33 \\
4 people & 23 & 38.33 \\
5 people & 4 & 6.67 \\
6 people & 2 & 3.33 \\
\hline Total & 60 & 100.00 \\
\hline
\end{tabular}

$\mathrm{N}=60$. Source: fieldwork conducted in the coastal area.

The percentage of respondents whose family members consisted of three people with one child and two parents was $48.33 \%$, followed by those with four family members comprising two children and two parents was 38.33\% (Table 6.7). Just $6.67 \%$ and $3.33 \%$ had five members comprising three children and two parents and six members comprising four children and two parents, respectively, suggesting that there was some concern of family welfare amongst the people. 


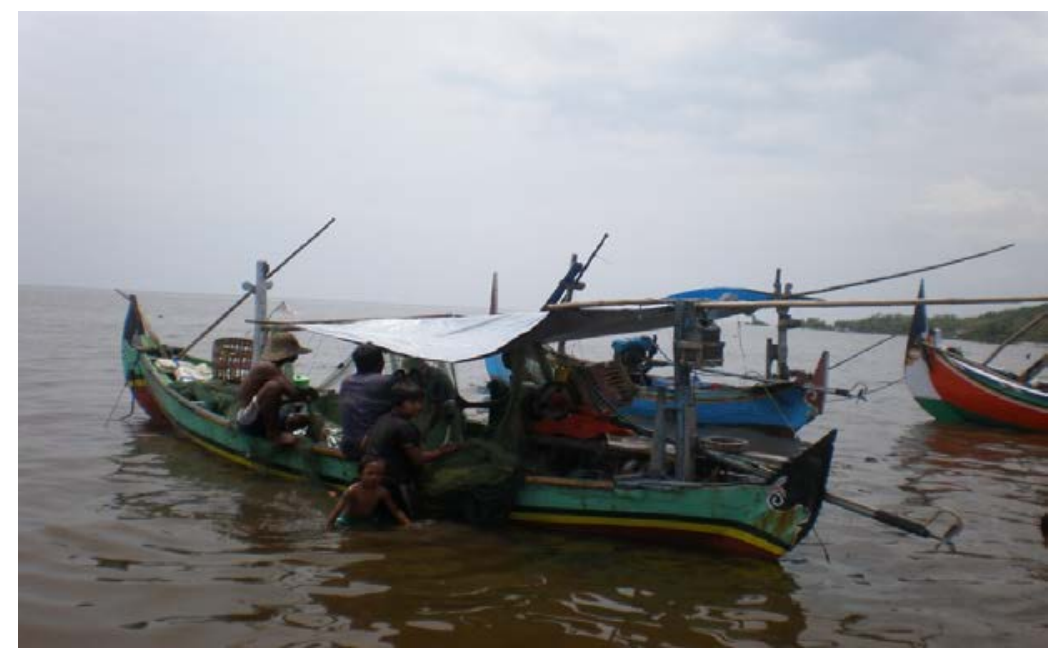

Figure 6.8: Family members’ involvement in fishing.

\subsection{Microfinance Institutions in the Coastal Area of Nguling Subdistrict}

The microfinance institutions in the coastal area were characterized by diversity; formal and informal financial institutions consisted of the central government providing some financial services through BRI Village Unit and Bank Perkreditan Rakyat (Rural Credit Bank) and Islamic microfinance institutions. Along with the income generated from natural resources, the localsparticularly those who lack the collateral that allows them get loans from a bank-obtain financial services from the Ministry Of Cooperative. The Islamic microfinance institutions, most of whose officials graduated from Islamic boarding schools, were generally trusted by the people. The establishment of these micro financial institutions impacted the businesses of the communities.

There were a large number of microfinance institutions providing financial services to the local communities in the coastal area (Table 6.8). Moreover, the informal micro financial system that was applied by the local people many years ago is shown to have developed well, such as the Rotating Savings and Credit Association (ROSCA), and loans from relatives and money lenders. The informal financial associations were formed based on the shared needs and aspirations of the locals. For example, the desire to overcome their financial problems spurred the formation of the fishermen groups. 
Table 6.8: Microfinance institutions.

\begin{tabular}{|c|c|c|c|c|c|c|}
\hline \multirow{3}{*}{$\begin{array}{l}\text { Types } \\
\text { Microfinance }\end{array}$} & \multicolumn{2}{|c|}{ Total Members } & Employees & \multirow{3}{*}{$\begin{array}{r}\text { Assets } \\
\text { Rp (000) }\end{array}$} & \multicolumn{2}{|c|}{ Volume of business } \\
\hline & \multirow{2}{*}{ Male } & \multirow{2}{*}{ Female } & \multirow{2}{*}{ (People) } & & 2009 & 2010 \\
\hline & & & & & $\mathrm{Rp}(000)$ & $\mathrm{Rp}(000)$ \\
\hline \multicolumn{7}{|c|}{ Koperasi Unit Desa Pertanian: } \\
\hline Budi Raharjo & 1.682 & 1.121 & 4 & $1,126,425$ & 95,875 & 47,950 \\
\hline \multicolumn{7}{|l|}{ Koperasi Perikanan } \\
\hline Sumber & & & & & & \\
\hline Samudra & 39 & 26 & - & 55,532 & & \\
\hline \multicolumn{7}{|l|}{ Koppontren: } \\
\hline Darul Ulum & 27 & 18 & - & 1,350 & - & - \\
\hline Nurul Huda & 30 & 7 & - & 12,819 & - & - \\
\hline \multicolumn{7}{|c|}{ Koperasi Pegawai Republik Indonesia: } \\
\hline Kec. Nguling & 149 & 130 & 8 & $2,110,147$ & $2,027,166$ & $1,888,013$ \\
\hline \multicolumn{7}{|l|}{ Koperasi Serba Usaha: } \\
\hline Bina Usaha & 15 & 10 & - & 8,500 & - & - \\
\hline Bina Raharja & 29 & 2 & 10 & 306,436 & 86,700 & 6,083 \\
\hline \multicolumn{7}{|l|}{ Koperasi Wanita: } \\
\hline AnNisaNguling & - & 50 & - & 35,608 & 13,750 & 13,750 \\
\hline PKK Mekar Sari & - & - & - & - & - & 25,000 \\
\hline Unggul Jaya & - & - & - & - & - & 25,000 \\
\hline PKK El Caesa & - & - & - & - & - & 25,000 \\
\hline Sinar Laut & - & - & - & - & - & 25,000 \\
\hline Sumber Laut & - & - & - & - & - & 25,000 \\
\hline \multicolumn{7}{|l|}{ Koperasi PK. Lima: } \\
\hline Kop. Lestari & 156 & 81 & & 345,882 & 227,000 & 227,000 \\
\hline \multicolumn{7}{|c|}{ Bank Perkreditan Rakyat (Rural Credit Bank): } \\
\hline PT BPR & - & & - & - & - & - \\
\hline $\begin{array}{ll}\text { Bank } & \text { Rakyat } \\
\text { Indonesia } & \end{array}$ & - & & - & - & - & - \\
\hline BRI unit desa & - & & - & - & - & - \\
\hline \multicolumn{7}{|c|}{ Baitul Maal wa Tamwil (Islamic Financial Cooperative): } \\
\hline BMT Nguling & & 783 & 6 & $2,292,000$ & - & 900,000 \\
\hline
\end{tabular}

Source: Various data from the cooperative office of Pasuruan Regency (April 2011), with modification.

There were a large number of microfinance institutions providing financial services to the local communities in the coastal area (Table 6.8). Moreover, the informal micro financial system that was applied by the local people many years ago is shown to have developed well, such as the Rotating Savings and Credit Association (ROSCA), and loans from relatives and money lenders. The informal financial associations were formed based on the shared needs and aspirations of the 
locals. For example, the desire to overcome their financial problems spurred the formation of the fishermen groups.

\subsubsection{ISLAMIC MiCROFINANCE INSTITUTIONS: FROM CONVINCING CUSTOMERS TO AN AWARD}

The reason behind communities adopting microfinance institutions is the necessity to inject the capital that drives economic activities. The microfinance institution is especially designed to help the poor, who are unable to obtain loans because of their lack of precious goods. In this region, the local people had good records of loan repayment, even though the financial institutions charged relatively high interest rates. However, societal trauma still existed because of the failures of previous institutions. These institutions suffered from poor management, along with a lack of due diligence on the part of their officials. In reality, the establishment of these financial institutions was expected to give some financial support to the people who had no collateral, in particular, and thus came with expectation of risk. The succeeding Islamic microfinance institutions experienced some constraints and challenges in the beginning of their establishment, because of the bad experiences people had with their predecessors. Mambaul Ulum (pers. comm.), the director of an IsMFI in the coastal area explained the challenges his institution faced in its infancy:

The case of the microfinance institutions that existed before ours, namely BMT Muamalat and Koperasi Muawanah, was a big problem, because these financial institutions closed down without notifying their clients. These institutions did not give the money that was deposited by their clients back. It was then a serious problem when our institution started offering financial services in this area, since the clients of BMT Muamalat and Koperasi Muawanah asked our institutions to pay back their savings or deposits. The clients thought that our institution was the same as the former institutions, and should take responsibility for their failures. It took time to convince the clients by visiting their houses intensively to clarify that our Islamic microfinance institution was not the same institution as they suspected. 
Table 6.9: The informal education of the respondents.

\begin{tabular}{lrr}
\hline Informal Education & No. of respondents & Percent \\
\hline Pondok pesantren & 30 & 50 \\
Entrepreneurship & 1 & 1.66 \\
Skills & 3 & 5 \\
No informal education & 26 & 43.33 \\
\hline Total & 60 & 100 \\
\hline
\end{tabular}

$\mathrm{N}=60$. Source: fieldwork conducted in the coastal area.

Half of the respondents (50\%) in the coastal area graduated from a pondok pesantren (Table 6.9). This was followed by those who had no informal education, with $43.33 \%$. People who graduate from pondok pesantren likely have a better understanding of Islamic teachings, law, and finance. Therefore, our data suggests that a large number of people in this region may have been better equipped to understand the concepts and schemes offered by the Islamic MFIs, increasing the possibility of a larger client base.

Since there were some graduates from pondok pesantren living in this area, providing Islamic teachings twice weekly, the clients of former microfinance institutions gradually began to trust the IsMFIs. The village leader could not stop the clients of the former institutions from showing their anger by breaking into the abandoned offices and removing their furniture and supplies. Chuzaimi (pers. comm.), a leader of one village in the coastal area, elaborates:

There were many clients who could not take their savings back from the previous microfinance institutions, and the communities were traumatized. They were reluctant to use microfinance institutions, regardless of the contract (applying Islamic law or not), even though they had already looted the offices of the previous microfinance institutions.

The director of an Islamic microfinance institution in the coastal area told us that the evolution of microfinance institutions applying Islamic laws can be divided into several periods:

1. Before May 2006, there were two microfinance institutions providing financial services to the communities. Both failed as a result of poor management and oversight. When they closed, they did not return their deposits to their clients.

2. Between May 2006 and mid-2009 was a challenging period, during which the Islamic MFIs tried to convince the communities that they were different from the former financial institutions. During this period, the Islamic microfinance institutions went doorto-door, giving balance information to their clients. Sometimes, they asked the local 
leader to persuade the people to adopt their financing or loan schemes. The institution had promotions in which they offered soft financing between Rp 100,000 and Rp 500,000 , which were directed to small traders and fishermen. Using the door-to-door method, the development of savings and financing schemes increased and improved. However, the number of potential clients whose economic activities relied on marine resources was still limited. As reported by the director of an Islamic microfinance institution, the total clients were around 600 people in 2008.

3. By 2009 and 2010, the communities had already forgotten the big issues regarding the past failures of the financial institutions. The clients who received less than $\mathrm{Rp} 500,000$ in financing from an Islamic MFI, named BMT MMU, did not need to provide collateral. Eighty percent of the total clients derived their income from the sea, while the other $20 \%$ were small entrepreneurs. The Islamic microfinance institutions started to give financing for a maximum of two years to the people who received more than $\mathrm{Rp} 2,000,000$. The performance of a Non Performance Loan (NPL) in this period was about 2-3\%, which is categorized as low. The total amount of deposited money was around Rp 1.25 billion, along with financing to clients. During these years, the Islamic microfinance institutions distributed all third-party funds to clients who needed financing and applied for qard al hasan and profit-sharing schemes. At the end of 2010, an Islamic microfinance institution, BMT MMU Nguling Subdistrict, received an award from the headquarters of MMU as a result of the institution's good performance.

4. Since 2011, the communities have seen the benefits of the establishment of Islamic microfinance institutions, since the percentage of clients who were provided with qard al hasan was around $20 \%$.

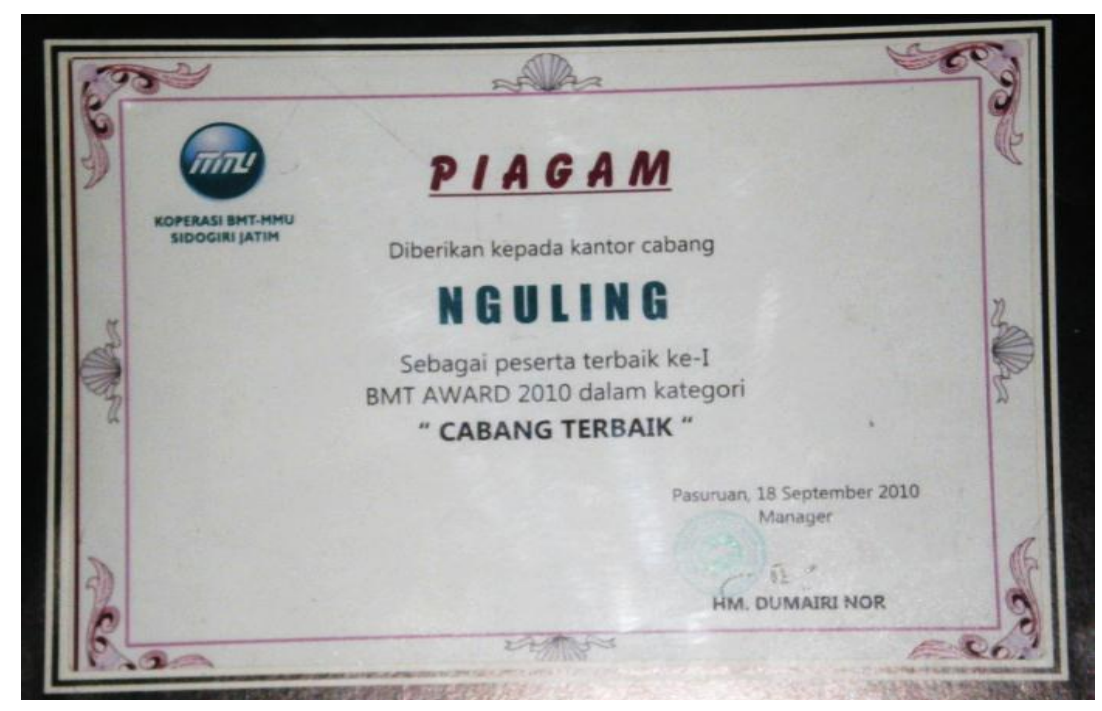

Figure 6.9: The award presented to BMT MMU Nguling Subdistrict. 


\subsubsection{ConVEntional Microfinance Institutions: AN IMBALANCE IN CREDIT DEMAND VERSUS NUMBER OF FINANCIAL INSTITUTIONS}

Because the local people need loans to form a part of their daily income, the communities had high expectations of the microfinance institutions. Many microfinance institutions provided financial services to the local people's businesses. Some were regulated by the Ministry Of Cooperative, and some others were raised by the locals, such as ROSCAS and Group Savings. The microfinance institutions in this area were mostly focused on providing financial services to the fisheries and small entrepreneurs.

Seeing the high financial demand from fisheries, some financial institutions competed to offer better financial services to their potential clients, seeing a correlation between financial scheme and client base. However, the number of financial institutions in this area, as well as their sources of capital, is not balanced by the financial needs of the communities who at the same time require funds to carry out their work. These high financial demands attracted financial institutions located outside of the region to compete with those found within Nguling Subdistrict. BRI Village Unit, which had better a management system and infrastructure than its competitors, benefited from this competition because it was able to satisfy the needs of the communities, who wanted to obtain credit quickly, and use its modern facilities to its advantage.

Additionally, even when the locals saw increased income because of larger fish numbers, they still attempted to gain additional capital-whether through Islamic contracts, conventional credit, or money lenders-in order to fund other economic activities. The imbalanced financing and loaning services provided by the MFIs in this area allowed other institutions from other regions, as well as informal financial institutions such as money lenders, to take part.

\subsection{Microfinance and Poverty Alleviation}

Theoretically, microfinance should make significant contributions toward improving welfare, especially when clients are equipped with the skills, training, and knowledge to excel in their chosen fields. The biggest contribution of microfinance has been showing that lending to the poor is feasible and that keeping good repayment records is achievable when institutions are appropriately designed (Hamada 2010).

A natural advantage of our research area was the ability of its community to make the most of its surroundings to earn income. At the same time, however, the communities faced problems with increasing production because the financial institutions were unable to offer more capital to them 
in the form of credit schemes. Because the communities' economic livelihoods were small-scale, they were not able to go fishing without additional financial support.

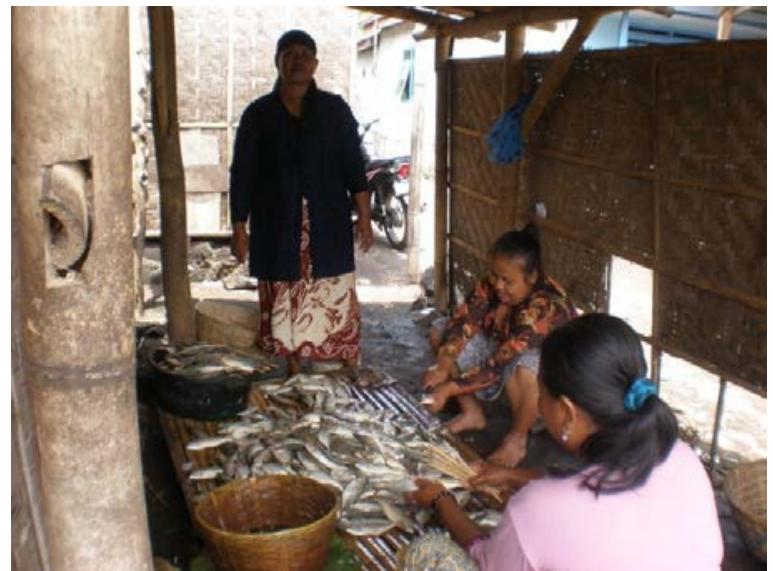

Figure 6.10: Processing a catch.

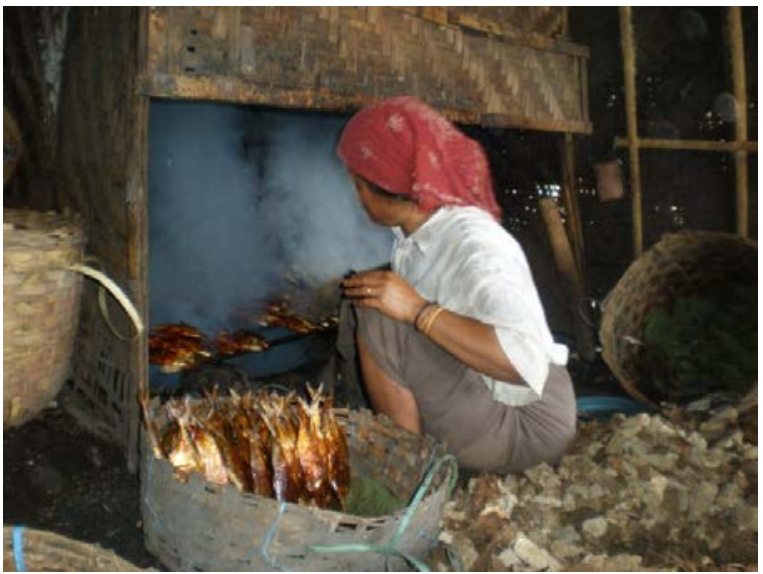

Figure 6.11: Grilled processing.

Generally, processing fish, which included grilling or canning them, was conducted by the wives of fishermen. Sometimes, their children also assisted. In this manner, the local people developed their family income and attempted to increase their welfare. Revenues compared with the owners of large ships, who employed their own laborers to do the fishing for them, were much lower; however, because of their ability to use their goods as guarantees, the people had better access to loans and financial support.

Table 6.10: Monthly household incomes and expenditure.

\begin{tabular}{lrr}
\hline Indicators & No. of respondents & Percent \\
\hline Income per month (Rupiahs): & 3 & \\
250,001-500,000 & 3 & 5.00 \\
500,001-750,000 & 7 & 11.67 \\
$750,001-1,000.000$ & 19 & 31.67 \\
1,000,001-1,500,000 & 9 & 15.00 \\
1,500,001-2,000,000 & 18 & 30.00 \\
2000,001-5,000,000 & 1 & 1.67 \\
$>$ 5,000,000 & & \\
Expenditure per month (Rupiahs): & 0 & 0.00 \\
250,000 or less & 7 & 11.67 \\
250,001-500,000 & 12 & 20.00 \\
$500,001-750,000$ & 19 & 31.67 \\
$750,001-1,000,000$ & 9 & 15.00 \\
$1,000,001-1,500,000$ & 9 & 15.00 \\
$1,500,001-2,000,000$ & 4 & 6.67 \\
2,000,001-5,000,000 & 0 & 0.00 \\
$>$ 5,000,000 & & \\
\hline
\end{tabular}

$\mathrm{N}=60$. Source: fieldwork conducted in the coastal area. 
Table 6.10 shows that the highest percentage of household's heads (31.67\%) were those who earned between Rp 1,000,000-1,500,000. The respondents who had a monthly income of Rp 750,000-1,000,000 accounted for the second-highest percentage (11.67\%), while those who brought in Rp 250,000-500,000 and Rp 500,000-750,000 accounted for 5\% each. The people who had low incomes usually applied for qard al hasan from the Islamic microfinance institutions. The targeted clients would only pay the principal capital and a small administration fee for a weekly installment scheme that lasted around two months. Fifteen percent of the total group had monthly incomes of Rp 1,500,001-2,000,000, which is categorized as vulnerable to poverty. The clients who had incomes of more than Rp 2,000,000 had to provide collateral, and did so in the form of deeds to their vehicles (BPKB) or other valuable objects.

Regarding family expenditures, the highest percentage of respondents (31.67\%) had expenditures of Rp 750,001-1,000,000, while those spending Rp 500,001-750,000 accounted for 20\%. Only a very small minority (6.67\%) had expenditures of Rp 2,000,001-5,000,000, while none had expenditures exceeding Rp 5,000,000.

Table 6.11: Cross tabulation between monthly household income and expenditure.

\begin{tabular}{|c|c|c|c|c|c|c|c|}
\hline Cross tabulation & & & Ionthly $\epsilon$ & penditure & 000 Rupi & & \\
\hline $\begin{array}{l}\text { Main and side } \\
\text { income (Rupiahs) }\end{array}$ & $\begin{array}{l}250,1 \\
-500\end{array}$ & $\begin{array}{l}500,1- \\
750,\end{array}$ & $\begin{array}{l}750,1- \\
1000\end{array}$ & $\begin{array}{l}\text { 1000,1- } \\
1,500\end{array}$ & $\begin{array}{l}1,500,1 \\
-2,000,\end{array}$ & $\begin{array}{l}2,000,1- \\
5,000\end{array}$ & $\begin{array}{l}> \\
5,000\end{array}$ \\
\hline $250,001-500,000$ & 1 & 1 & 1 & 0 & 0 & 0 & 0 \\
\hline $500,001-750,000$ & 1 & 2 & 0 & 0 & 0 & 0 & 0 \\
\hline $750,001-1000,000$ & 3 & 1 & 2 & 0 & 1 & 0 & 0 \\
\hline $\begin{array}{l}1,000,001- \\
1,500,000\end{array}$ & 2 & 5 & 7 & 5 & 0 & 0 & 0 \\
\hline $\begin{array}{l}1,500,001- \\
2,000,000\end{array}$ & 0 & 1 & 5 & 1 & 1 & 1 & 0 \\
\hline $\begin{array}{l}2,000,001- \\
5,000,000\end{array}$ & 0 & 2 & 4 & 3 & 7 & 2 & 0 \\
\hline$>5,000,000$ & 0 & 0 & 0 & 0 & 0 & 1 & 0 \\
\hline Total & 7 & 12 & 19 & 9 & 9 & 4 & 0 \\
\hline
\end{tabular}

$\mathrm{N}=60$. Source: fieldwork conducted in the coastal area.

However, the communities still needed attention from the local government in terms of health care, as they were unable to purchase foods with enough nutrition because of their low purchasing power. For this reason, the presence of microfinance institutions was also meaningful to the communities in the coastal area. 
Table 6.12: Cross tabulation between family size and income.

\begin{tabular}{lrrrrr}
\hline Cross tabulation & \multicolumn{7}{c}{ Number of Family members } \\
\hline Main and side income (Rupiahs) & 2 & 3 & 4 & 5 & 6 \\
\cline { 2 - 6 } $250,001-500,000$ & 0 & 3 & 0 & 0 & 0 \\
$500,001-750,000$ & 0 & 3 & 0 & 0 & 0 \\
$750,001-1000,000$ & 1 & 4 & 2 & 0 & 0 \\
$1,000,001-1,500,000$ & 1 & 10 & 6 & 2 & 0 \\
$1,500,001-2,000,000$ & 0 & 3 & 5 & 0 & 1 \\
$2,000,001-5,000,000$ & 0 & 5 & 10 & 2 & 1 \\
$>5,000,000$ & 0 & 1 & 0 & 0 & 0 \\
\hline Total & 2 & 29 & 23 & 4 & 2 \\
\hline
\end{tabular}

$\mathrm{N}=60$. Source: fieldwork conducted in the coastal area.

Table 6.12 shows that 10 (16.67\%) of the respondents had both incomes of Rp 1,000,0011,500,000 and households consisting of three family members. Six of the households (10\%) who also earned Rp 1,000,001-1,500,000 consisted of four family members. Additionally, 10 respondents (16.67\%) whose households also consisted of four members had incomes of $\mathrm{Rp}$ 2,000,001-5,000,000. These data indicate that the respondents were still around the poverty line, since they had to cover both regular expenditures and repayments-in the form of installments-to the microfinance institutions. 
Box 7.1: Microfinance and poverty alleviation.

In-depth interviews of the microfinance institutions' clients were conducted to explore the effect of microfinance on poverty alleviation. The first client we interviewed was Nukman Hadi, who joined an Islamic microfinance institution in 2007. In 2005, he started a small business selling clothes as a means of supporting his family. Applying for a profit-sharing scheme, Hadi received financing four times. Regarding poverty, he said, "I obtained certain benefits after applying for financing from the Islamic microfinance institution in return for about $30 \%$ of net profit."

The second client was llyas, a 42-year-old who has graduated from a pondok pesantren and joined a conventional microfinance institution in 2006. His business, which opened in 2007, involved selling fertilizer to farms, in order to both support his family and fulfill a market demand for fertilizer. Speaking on the role of microfinance on his family welfare, he said, "My business's profits have increased by $27 \%$. This has improved my family's welfare."

The third client, Abdul Aziz, this time from an Islamic microfinance institution, applied for and received financing in a profit-sharing scheme in 2007. He started his business two years later. On his institution, he said, "After receiving financing, my business' profits increased by around $20 \%$. The welfare of my family as well as the scale of the business also increased. "

The fourth client we interviewed was Sutrisno, a man with four family members who has been receiving credit from a conventional microfinance institution since 2001 for his business, which started in 2007. His business involved selling agricultural products-such as fertilizer, seeds, pesticide, and tools - to farmers. Relating his experiences with his institution, he said, "The scale of my business, as well as its profits, increased after I received credit from the microfinance institution. These increased profits have helped my business thrive, and consequently, improved my family's welfare."

Imam Baihaqi, the fifth client, had three family members, and applied for credit in 2007 . He started his business in 2005, intending to cover his family's daily needs. Regarding the change in his family's welfare, he said, "The welfare of my family increased after I received credit from the microfinance institution, positively affecting my business."

In general, the existence of the microfinance institutions in the coastal area positively affected the communities' economic activities. Both the welfare of families and state of their businesses were improved after they received financing or credit from the MFIs. 


\subsection{Microfinance and Environmental Awareness in the Coastal Area; the Communities’ Focus on Income Generation over Environmental Awareness}

Microfinance institutions took part in promoting alternative sources of income. In the coastal area, the communities who became members of the microfinance institutions were able to both apply for credit or financing schemes and save their money. Along with these schemes, the microfinance institutions also claimed to tackle the common problem of environmental degradation by providing environmental awareness training. However, according to their clients, this was not the case. The absence of training programs from the institutions is considered to be one of the enablers of environmental degradation, since the clients have limited experience with this issue. Table 6.13 presents whether the respondents thought the microfinance institutions provided training on environmental issues.

Table 6.13: Training on environmental issues provided by the MFIs.

\begin{tabular}{|c|c|c|c|}
\hline $\begin{array}{l}\text { Do MFIs provide } \\
\text { environmental issues? }\end{array}$ & training on & No. of respondents & Percent \\
\hline Yes & & 7 & 11.67 \\
\hline No & & 23 & 38.33 \\
\hline Don’t know & & 30 & 50.00 \\
\hline Total & & 60 & 100.00 \\
\hline
\end{tabular}

$\mathrm{N}=60$. Source: fieldwork conducted in the coastal area.

Fifty percent of the clients did not know whether MFIs provide training on environmental issues, with 38.33\% reporting that they did not receive training on environmental matters. Conversely, only $11.67 \%$ of the respondents reported receiving training in their area. These data indicate that the lack of environmental awareness on the part of the communities in the coastal area may have been the result of the absence of training by the MFIs, as well as the fact that they had little knowledge regarding environmental issues in the first place. Olli, Grendstad, and Wollebaek (2001) point out that training programs will play an important role in persuading uneducated people to have more awareness on environmental issues, because there are negative relationships between income and all dimensions of environmental behavior.

Islamic MFIs have the option of using social funds obtained from charities, especially during the month of Ramadan, to empower the poorest and assist with natural disasters, environmental improvement, and other social activities. 
Table 6.14: Social programs provided by the MFIs.

\begin{tabular}{lrr}
\hline Do MFIs provide social programs? & No. of respondents & Percent \\
\hline Yes & 9 & 15.00 \\
No & 24 & 40.00 \\
Don't know & 27 & 45.00 \\
\hline Total & 60 & 100.00 \\
\hline
\end{tabular}

$\mathrm{N}=60$. Source: fieldwork conducted in the coastal area.

Table 6.14 shows that $45 \%$ of respondents did not know whether the MFIs provide social programs on environmental awareness. Forty percent of respondents reported that they did not take part in social programs, contrasting the $15 \%$ who reported in the affirmative. These data indicate that the MFIs might be conducting social programs on environmental issues in certain parts of the coastal area, only, with low levels of impact.

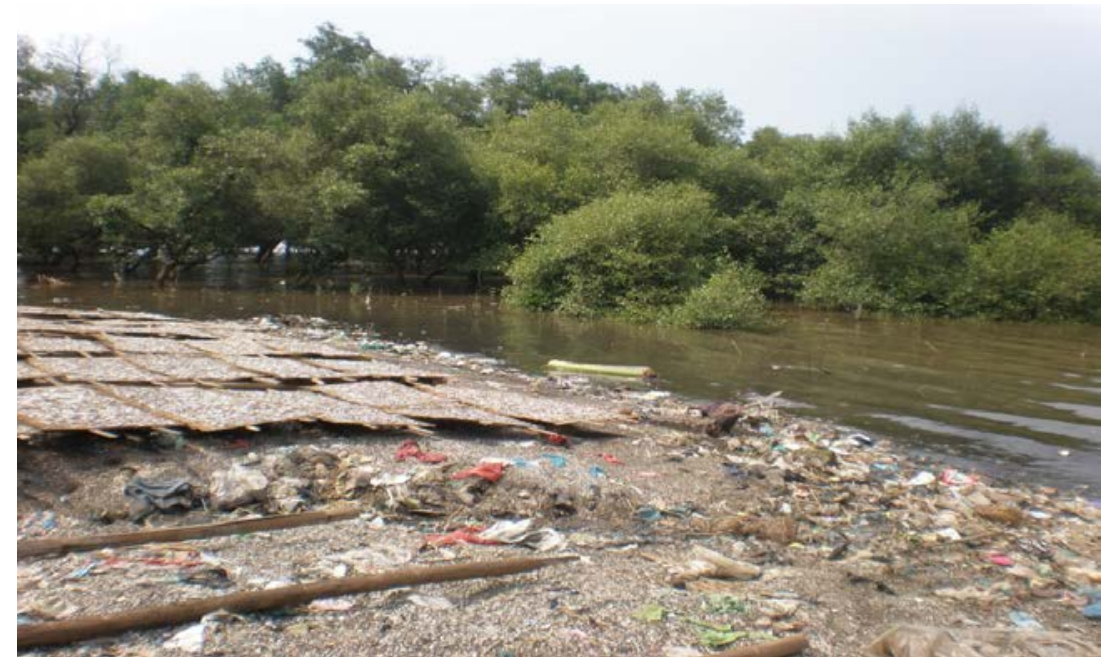

Figure 6.12: Drying fish around coastal trash, illustrating environmental ignorance. Societal garbage affects both the environment and humans, as it poses a hygiene problem for locals and consumers.

In spite of this, the local people also reported that they did not have any serious problems in maintaining the environment around them (Table 6.15).

Table 6.15: Problems faced by the respondents.

\begin{tabular}{lrr}
\hline $\begin{array}{l}\text { Do you perceive any problems in } \\
\text { maintaining the environment? }\end{array}$ & 14 & No. of respondents \\
\hline Yes & 46 & 76.67 \\
No & 60 & 100.00 \\
\hline Total
\end{tabular}

$\mathrm{N}=60$. Source: fieldwork conducted in the coastal area. 
Table 6.15 shows that respondents who said they did not have any difficulties in maintaining the environment accounted for $76.67 \%$ of the total group, while only $23.33 \%$ reported having problems. Two of these problems were a lack of clear regulations on environmental matters and infrastructure. Prater and Ghosh (2005) claim that there is a need to determine whether governmental policies or documented business practices exist that can facilitate small and medium-sized enterprises (SMEs) into embracing environmental issues. It is also apparent that while the respondents had no serious problems related to paying attention to their environment, they felt that it might be costly to allocate money toward adopting good environmental practices. Simpson, Taylor, and Barker (2004) conclude that most organizations surveyed believed environmental issues to be issues affecting business. However, meeting these requirements was seen as a cost that was not transferable to customers in terms of added benefits, and few organizations could show that it led to a competitive advantage. On the other hand, small businesses will experience more difficulties than their larger counterparts when engaging in socially responsible actions (Lepoutre and Heene 2006). However, if we look at the reality of the environment in which they live, the local people had limited awareness of the effects of their routine business activities, such as the proximity of their sun-dried fish to coastal trash (Figure 6.12) or the heavy amount of smoke associated with grilling fish (Figures 6.13 and 6.14).

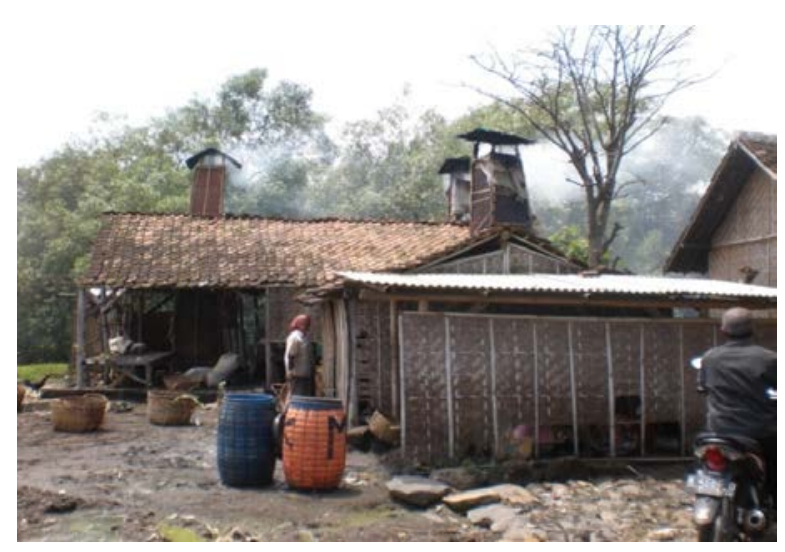

Figure 6.13: Smoke escaping from chimneys.

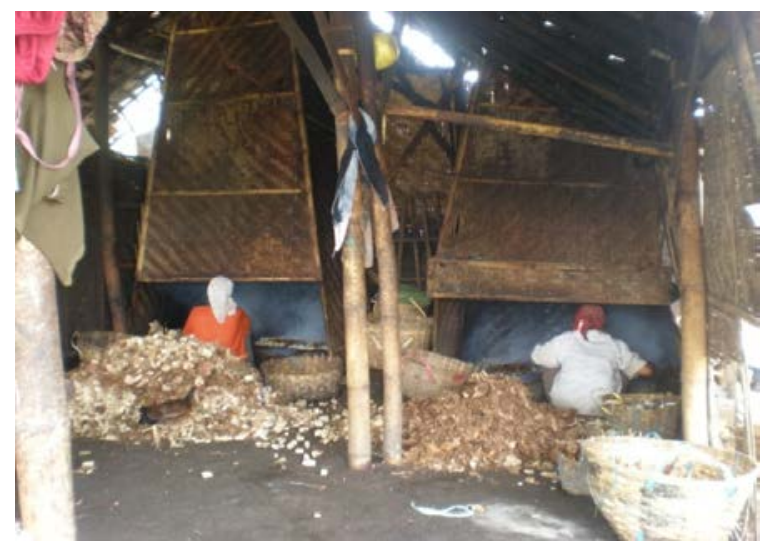

Figure 6.14: The smoke produced by grilling fish.

We found the local people in our research area to have little education, particularly on environmentally-friendly business practices. The communities thought that their actions regarding their businesses’ environmental impacts were the correct ones, assuming that they had already paid an adequate amount of attention to the environment. 
Table 6.16: Reaction of the community to environmental damage.

\begin{tabular}{|c|c|c|}
\hline $\begin{array}{l}\text { How would you react to damage to your } \\
\text { environment? }\end{array}$ & No. of respondents & Percent \\
\hline $\begin{array}{l}\text { I will report to the village leader or village } \\
\text { organizations. }\end{array}$ & 13 & 21.67 \\
\hline $\begin{array}{l}\text { I will reduce the environmental damage to the best } \\
\text { of my ability. }\end{array}$ & 28 & 46.67 \\
\hline $\begin{array}{l}\text { I will invite my neighbor(s) to help me improve the } \\
\text { environment's condition. }\end{array}$ & 19 & 31.67 \\
\hline Total & 60 & 100.00 \\
\hline
\end{tabular}

$\mathrm{N}=60$. Source: fieldwork conducted in the coastal area.

Table 6.16 shows that $46.67 \%$ of respondents would attempt to reduce the environmental damage to the best of their ability. Hence, if they were more knowledgeable of how to manage the environment, their efforts would be more effective. This would also be favorable for the $31.67 \%$ who said they would invite their neighbor(s) to assist them. A further $21.67 \%$ said they would only report the damage to their superiors, indicating that a minority of the respondents were more passive regarding environmental damage. Steel (1996) suggests that attitude intensity is correlated with self-reported environmental behavior and political activism in environmental issues, controlling for socio-demographic factors. Respondents with environmentally-protective attitudes reported that they were "thinking globally and acting locally".

Mangrove forests were one of the essential coastal ecosystems providing economic benefits to the local people, since they were able to make use of their wide range of by-products. Still, mangrove forests are also important in providing ecosystem services, such as protection from tsunamis (Kathiresan and Rajendran 2005). Some of the locals in our research site tended to have improved family incomes by creating tambak (brackish water ponds) near mangrove forests, while paying less attention to their consequent degradation (Figure 6.15).

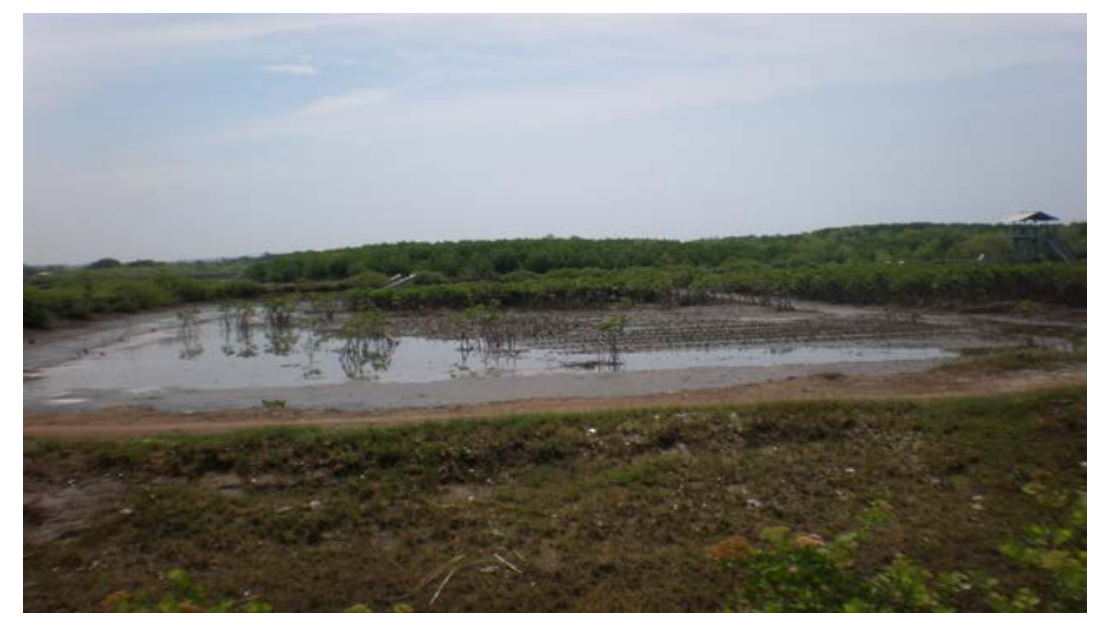

Figure 6.15: Degradation of a mangrove forest resulting from tambak expansion. 
Mangrove forests in the coastal area of Nguling Subdistrict were reported to be in critical condition because of tambak expansion, as well as illegal logging by locals seeking to have extra income. Tambak was one of the most common forms of land use. It was also a common cause of conflict. Nurkin (1994) reported a similar case in Sulawesi, where tambak was one of the main reasons for the increasing rate of mangrove forest exploitation, along with logging for timber and fuel wood collection. Although the communities in our study area knew of the importance of these mangrove forests, the fact that they did not feel very attached to the area meant they also felt little guilt for the consequences of tambak creation and illegal logging (Muryani et al. 2011). The high rate of mangrove forest conversion in this area calls for an immediate response in the form of policy and managerial measures aimed at restoring them and alleviating the ecological and socio-economic impacts of aquaculture development. These would require a formulation of measures, their implementation, and monitoring strategies that contest existing policy narrative and challenge entrenched economic interests and power relationships (Armitage 2002).

Box 6.2: Microfinance institution clients on environmental issues.

Some respondents were interviewed to collect information on the impact of the MFIs on environmental awareness in the coastal area of Nguling Subdistrict. The first client we interviewed was Sohib, who received Rp 2,000,000 in financing from an Islamic microfinance institution since 2008, which served as additional capital for his grilled fish business that had been in operation since 2005. His business was located in a residential area, adjacent to his neighbors, who had similar businesses. According to him, the reason for his business was because there were no other economic options. On environmental issues, he said, "I have an idea to make a good chimney for the smoke of grilled processing in order to minimize the air pollution." Additionally, he said, "I threw the waste into the river, which empties into the sea as what was done by the village officials and other people."

Faried, the second client, started receiving financing for additional capital from an Islamic MFI services in 2006. He started his business of seven years in 2004 in order to support his family. He shared his experience with dealing with environmental damage with us, saying, "I will inform the village officials when there is environmental damage happening around the village."

The third client was Fatkhul Mubin, who, with four family members, applied for financial services from a conventional microfinance institution in 2000. His motivation to improve his family's welfare led him to start a business in the same year. Regarding environmental issues after joining an MFI, he said, "If the environment is damaged and polluted, I will inform my neighbors and ask them to make the improvements together with me."

The forth respondent was H Ali Toyyib, who had five family members and joined a conventional MFI to get additional capital in 2009. In connection with the environmental issues, he said, "My business has no negative impacts on the environment. However, I will inform the village officials when the environment in this area is polluted or damaged." 
A decline in marine resources puts coastal people at risk if investments are not made in other productive assets that facilitate future opportunities for livelihood diversification and employment (Tobey and Torell 2006). The MFIs in the coastal area of Nguling Subdistrict had a low impact on the communities' environmental concerns, since they were not provided with training and social programs on environmental issues. Thus, providing environmental awareness training to the members of MFIs and village leaders would contribute significantly to mitigating environmental degradation. Friedman, Miles, and Adams (2000) argue that SMEs cannot afford to pay environmental experts and consultants because environmental improvement is likely to cost companies rather than save or make them money. In our case, the communities focused solely on generating income without paying attention to the environmental impact of their businesses.

Micro-credit institutions may have negative impacts on sustainable resource use, by providing loans that increase fishing, the cutting of mangroves, or pollution from small cottage industries. Therefore, this potential negative impact needs to be mitigated through environmental sensitivity training amongst members and particularly among the leadership committees. In addition, provisions for simple environmental reviews should be considered for incorporation into village banking by-laws. 


\section{UPLAND AREa}

\subsection{Overview of Research Area}

The upland area of our research site was located in Purwosari Subdistrict. The region was situated in the southwestern part of Pasuruan Regency (7.30'-8.30'S and 112.30'-113.30'E, 100-500 m a.s.l.), east of the twin volcanoes of Arjuna and Arjuno (BPS 2011). The research site was chosen based on the area's diversity of financial institutions, as well as advice from the leaders of some microfinance institutions (MFIs).

Just as with the other areas in Pasuruan Regency, the upland area experienced only two seasons: rainy and dry. In the rainy season (October to April), the communities generally grew crops, such as rice, corn, eggplants, and other vegetables, and planted trees, such as sengon (Paraserianthes falcataria), kapok (Ceiba pentandra), and teak (Tectona grandis). In the dry season (May to September), the people dried some of their harvested agricultural products before selling them to the market.Because of the region's contributions to pillow and mattress production in Pasuruan, the inhabitants would also dry harvested kapok during the dry months.

Table 7.1: Number of rainy days, monthly rainfall, and daily average of rainfall.

\begin{tabular}{llrrr}
\hline No & Months & $\begin{array}{r}\text { Rainy } \\
\text { days }\end{array}$ & $\begin{array}{r}\text { Rainfall } \\
(\mathrm{mm})\end{array}$ & $\begin{array}{r}\text { Average } \\
\text { (mm/days) }\end{array}$ \\
\hline 1 & January & 18 & 441 & 24.50 \\
2 & February & 19 & 276 & 14.53 \\
3 & March & 20 & 385 & 19.25 \\
4 & April & 21 & 226 & 10.76 \\
5 & May & 16 & 276 & 17.25 \\
6 & June & 12 & 109 & 9.08 \\
7 & July & 6 & 154 & 25.67 \\
8 & August & 5 & 73 & 14.60 \\
9 & September & 9 & 213 & 23.67 \\
10 & October & 11 & 140 & 12.73 \\
11 & November & 9 & 189 & 21.00 \\
12 & December & 16 & 381 & 23.81 \\
\hline & Total & 162 & 2863 & 17.67 \\
\hline
\end{tabular}

Source: BPS, Statistic of Pasuruan Regency, Purwosari In Figures (2011), with modification.

The people in this region had a better level of education than the other studied regions, likely because it is located between two big student cities, Surabaya and Malang. The education level 
of village officials played a significant role in sustainable social and economic development. Some policies concerning economic empowerment, job opportunities, and eco-friendly business management within the region relied on decision-makers' knowledge and experience.

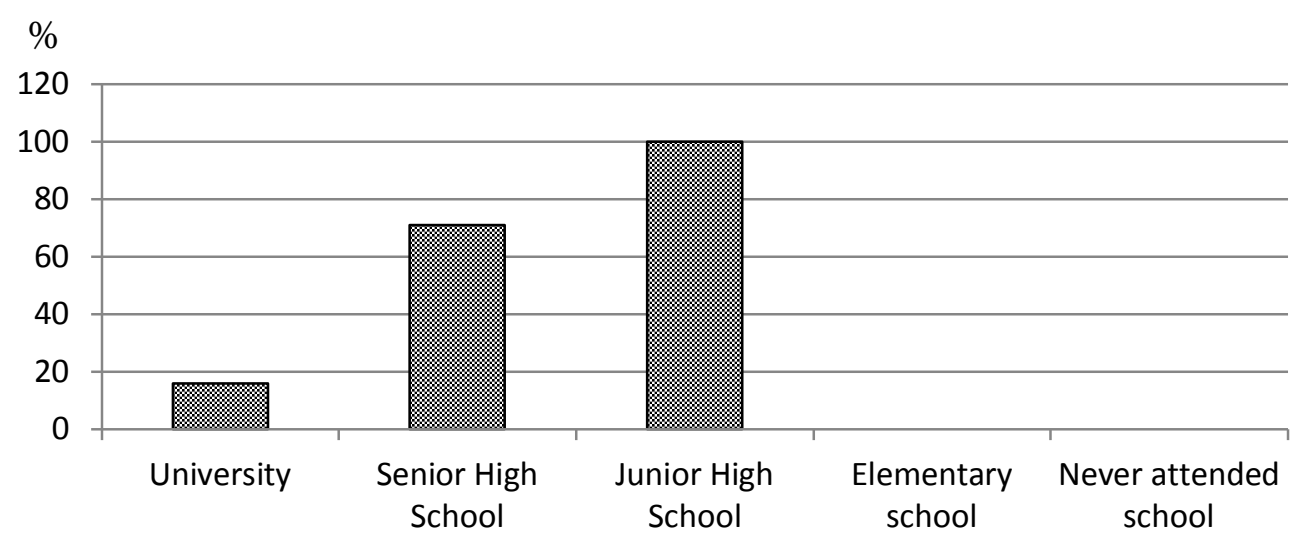

Figure 7.1: Education level of village officials in the research site. Source: BPS, Statistic of Pasuruan Regency, Purwosari In Figures (2011), with modification.

The local government of Pasuruan Regency established the upland area of Purwosari Subdistrict as a center of manufacturing, in order to provide employment opportunities to the local people, and enable the region's socioeconomic development to accelerate. Located in a mountainous area and surrounded by forest plantations, a large number of people were considered of productive age (Figure 7.2).
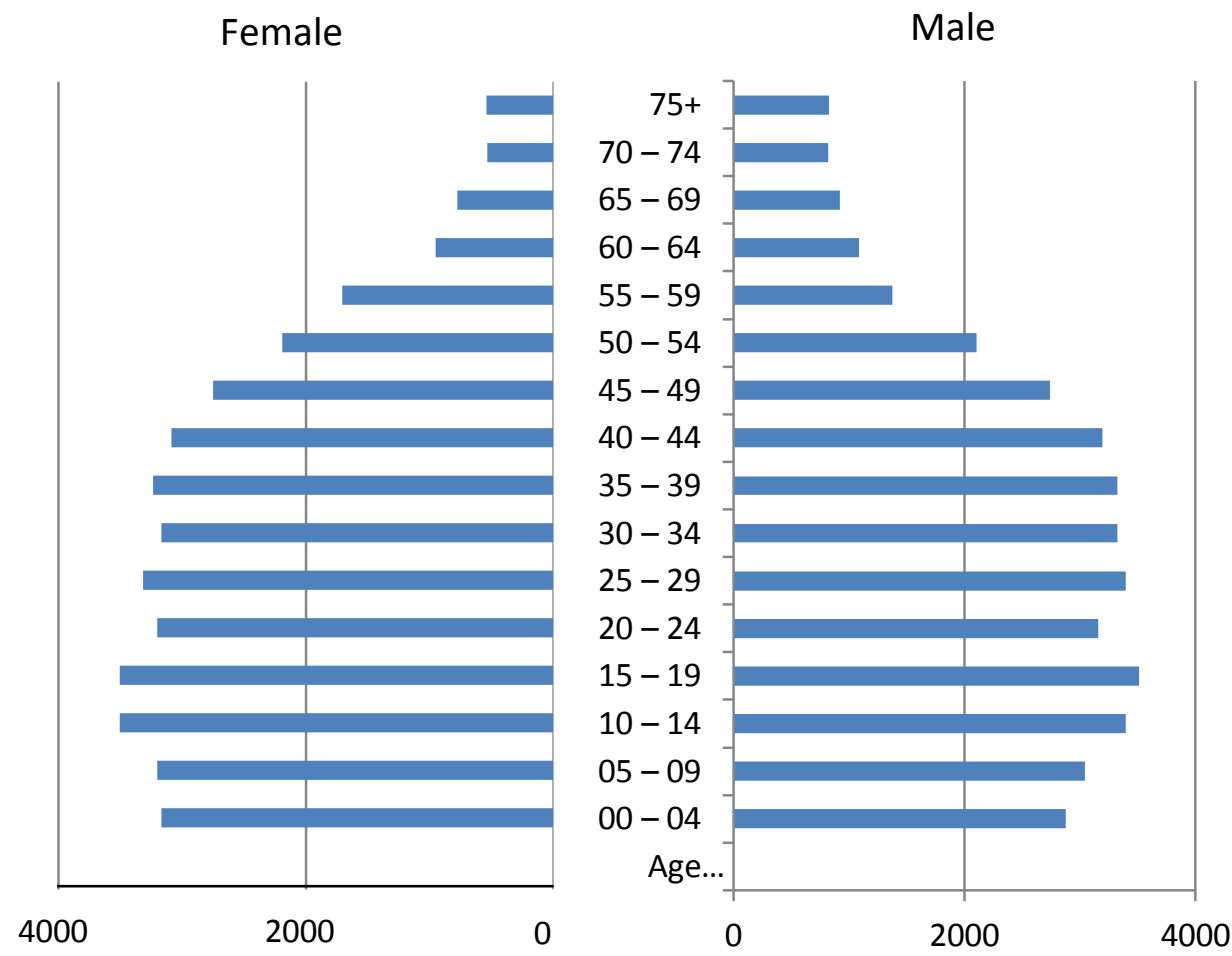

Figure 7.2: Population by age group. Source: BPS, Statistic of Pasuruan Regency, Purwosari In Figures (2011), with modification. 
The education levels of the people in the upland area are shown in Table 7.2.

Table 7.2: Education level of local people in research site.

\begin{tabular}{lrr}
\hline Level of schooling & No. of people & Percent \\
\hline Not/some elementary school & 12,009 & 18.74 \\
Completed elementary school & 27,168 & 42.40 \\
Completed junior high school & 13,529 & 21.12 \\
Completed senior high school & 9,634 & 15.04 \\
Completed diploma program & 497 & 0.78 \\
Academy/university & 1,143 & 1.78 \\
Master/doctoral degree & 91 & 0.14 \\
\hline Total & 64,071 & 100.00 \\
\hline
\end{tabular}

Source: BPS, Statistic of Pasuruan Regency, Purwosari In Figures (2011), with modification.

Graduates of elementary school accounted for $42.40 \%$ of the total population, followed by $21.12 \%$ who graduated from junior high school and $18.74 \%$ who had some or no elementary school (Table 7.2). Conversely, the lowest percentage $(0.14 \%)$ belonged to those who had obtained a master or doctoral degree, followed by those who completed a diploma program $(0.78 \%)$ and academy or university graduates, with $1.78 \%$. Although the education level of the people in the upland area was higher than that in the coastal and lowland areas, these percentages indicate that it was still quite low, in spite of it being the center of manufacturing in the region and being located between two large student cities.

Because the factories prefer to hire people with higher education-especially for positions that pay more-it is imperative that the level of education be at a high enough level to satisfy the factories' demand for skilled workers. Failing to do these risks the factories looking elsewhere for their high-skill positions, reducing the job opportunities of the inhabitants of this region, and consequently, along with their level of education, impacting their level of welfare. Despite the large number of factories in the upland area, many people were still unable to work in those industries.

\footnotetext{
${ }^{7}$ A diploma program takes one to three years to complete, and is more vocational than a university program. The certificate obtained is equivalent to an associate degree.
} 
Table 7.3: Level of welfare in the research site.

\begin{tabular}{lrr}
\hline Level of welfare & No. of people & Percent \\
\hline Pre-prosperous (very poor) & 3,760 & 16.44 \\
Welfare level I (poor) & 3,553 & 15.54 \\
Welfare level II & 5,692 & 24.89 \\
Welfare level III & 9,419 & 41.19 \\
Welfare level III + & 441 & 1.93 \\
Total & 22,865 & 100.00 \\
\hline
\end{tabular}

Source: BPS, Statistic of Pasuruan Regency, Purwosari In Figures (2011), with modification.

Table 7.3 shows that $41.19 \%$ of the respondents had level III welfare, although there were still people classified as very poor (16.44\%) and poor (15.54\%), further highlighting the level of poverty in the region.

\subsection{Characteristics of Respondent Households}

Three different types of respondents in the upland area of Purwosari were interviewed: clients of Islamic microfinance institutions, clients of conventional microfinance institutions, and key informants. The interviews were the same as those in the coastal and lowland areas.

Generally, the interviewed respondents still relied on agriculture for their livelihood, although they also derived their income from off-farm activities.

Table 7.4: Economic activities of head of household.

\begin{tabular}{lrr}
\hline Main occupation & No. of respondents & Percent \\
\hline Self-employed in agriculture & 35 & 58.33 \\
Self-employed in off-farm enterprises & 12 & 20.00 \\
Government employee & 3 & 5.00 \\
Casual/free worker & 1 & 1.67 \\
Salaried worker in non-agriculture & 9 & 15.00 \\
\hline Total & 60 & 100.00 \\
\hline
\end{tabular}

$\mathrm{N}=60$. Source: fieldwork conducted in the upland area.

Table 7.4 shows that $58.33 \%$ of respondents were self-employed in the agricultural sector. Twenty percent of respondents were self-employed in off-farm enterprises, such as producing bricks and cassava chips, drying kapok, and selling snacks, while salaried workers in various forms of manufacturing accounted for $15 \%$. The salaried workers sometimes had or rented land for growing crops, although the land was usually not as large as that owned by the self-employed farmers. 


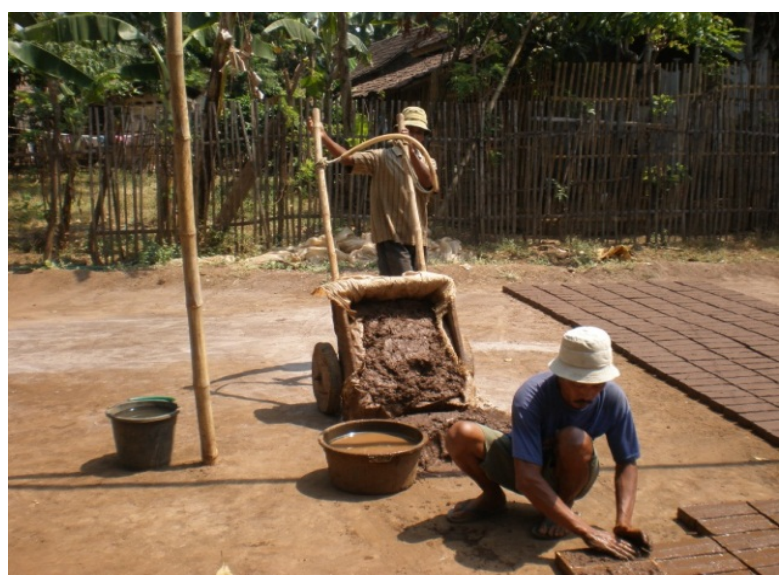

Figure 7.3: Producing bricks.

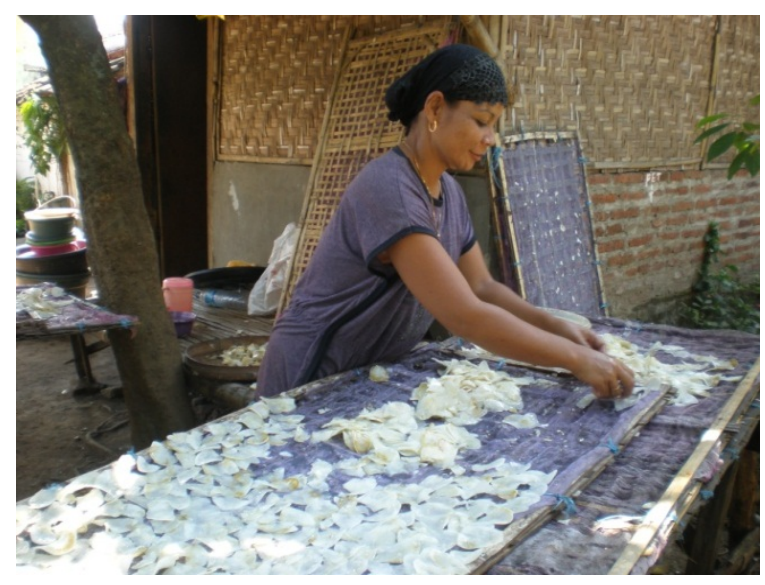

Figure 7.4: Drying cassava chips.

Table 7.5: Education level of household's head.

\begin{tabular}{lrr}
\hline Level of formal education & No. of respondents & Percent \\
\hline Never attended school & 0 & 0.00 \\
Some elementary school & 5 & 8.33 \\
Completed elementary school & 22 & 36.67 \\
Attended junior high school & 2 & 3.33 \\
Completed junior high school & 11 & 18.33 \\
Attended senior high school & 1 & 1.67 \\
Completed senior high school & 11 & 18.33 \\
Attended academy/university & 8 & 13.33 \\
\hline Total & 60 & 100.00
\end{tabular}

$\mathrm{N}=60$. Source: fieldwork conducted in the upland area.

Table 7.5 shows that $36.67 \%$ of household respondents had completed elementary school, and 8.33\% did not. Respondents who graduated from junior and senior high school accounted for $18.33 \%$, each, while graduates from an academy or university accounted for $13.33 \%$. Although the heads of household in the upland area generally had higher education levels than those in the lowland and coastal areas, these percentages indicate that they still were not able to take advantage of the employment opportunities in this region, since lucrative positions correlated with high education levels.

Another factor in each household’s head's ability to generate income was age (Table 7.6). 
Table 7.6: Age of each household's head.

\begin{tabular}{lrr}
\hline \multicolumn{1}{c}{ Age distribution } & No. of respondents & Percent \\
\hline $20-30$ years & 7 & 11.67 \\
$31-40$ years & 28 & 46.67 \\
$41-50$ years & 20 & 33.33 \\
$51-60$ years & 4 & 6.67 \\
61 above & 1 & 1.67 \\
\hline Total & 60 & 100.00 \\
\hline
\end{tabular}

$\mathrm{N}=60$. Source: fieldwork conducted in the Purwosari area.

The youngest respondent in the upland area was 21 years old, while the oldest was 61 . The highest percentage of respondents (46.67\%) was aged 31-40, followed by the $33.33 \%$ who were aged 41-50 (Table 7.6). These percentages suggest that the majority of people were of suitable ages to capitalize on the job opportunities present in this region.

Of the total population, 12,234 people adopted a family planning program (BPS 2011). A family planning program is meant to increase family welfare, which is affected by consumption as the result of family size.

Table 7.7: Number of family members per household.

\begin{tabular}{lrr}
\hline Family member of household & No. of respondents & Percent \\
\hline 2 people & 3 & 5.00 \\
3 people & 18 & 30.00 \\
4 people & 27 & 45.00 \\
5 people & 8 & 13.33 \\
6 people & 3 & 5.00 \\
7 people & 1 & 1.67 \\
\hline Total & 60 & 100.00 \\
\hline
\end{tabular}

$\mathrm{N}=60$. Source: fieldwork conducted in the upland area.

Table 7.7 shows that $45 \%$ of respondent households comprised four family members with two parents and two children. Thirty percent of households were made up of two parents and one child (three members). These data indicate that the interviewed respondents of our study had some family planning awareness. Meanwhile, $13.33 \%$ of households were composed of five members, indicating that a minority of people had less family planning awareness.

\subsection{Microfinance Institutions in the Upland Area of Purwosari Subdistrict}

The upland area of Purwosari Subdistrict had a variety of MFIs. The institutions were divided into two groups: formal and informal. The formal MFIs were under government supervision and 
regulation. These included Bank Perkreditan Rakyat (Rural Credit Bank), Bank Mandiri, and BRI village unit. Generally, these financial institutions had a microfinance division to provide services to people with low social status, and would require collateral from their credit applicants. In spite of the required guarantee from those microfinance divisions, the microfinance institutions provided by the Ministry Of Cooperative allowed clients to obtain credit without giving valuable things. The Islamic microfinance institutions (IsMFIs) offered financial services to clients based on Islamic laws, such as avoiding riba (interest), using profit and loss sharing schemes, and requiring their clients to adhere to fair business practices.

Table 7.8: Microfinance institutions.

\begin{tabular}{|c|c|c|c|c|c|c|}
\hline \multirow{3}{*}{ Types of MFIs } & \multicolumn{2}{|c|}{ Total Members } & \multirow{2}{*}{$\begin{array}{r}\text { Employees } \\
\text { (People) }\end{array}$} & \multirow{2}{*}{$\begin{array}{l}\text { Assets } \\
\text { Rp (000) }\end{array}$} & \multicolumn{2}{|c|}{ Volume of business } \\
\hline & Male & Female & & & 2009 & 2010 \\
\hline & & & & & $\mathrm{Rp}(000)$ & $\mathrm{Rp}(000)$ \\
\hline \multicolumn{7}{|c|}{ Koperasi Unit Desa Pertanian: } \\
\hline Margo Agung & 1.717 & 1.144 & 7 & $2,830,135$ & 537,894 & 268,948 \\
\hline \multicolumn{7}{|l|}{ Koppontren: } \\
\hline Al Hidayah & - & - & - & - & - & - \\
\hline Darut taqwa II & 87 & - & 31 & 734,682 & $4,027,002$ & $2,013,501$ \\
\hline \multicolumn{7}{|l|}{ Kopinkra: } \\
\hline Setia Bhakti & 78 & 42 & - & 287,352 & - & - \\
\hline \multicolumn{7}{|c|}{ Koperasi Pegawai Republik Indonesia: } \\
\hline $\begin{array}{l}\text { Kartika Prima } \\
\text { SMAN I }\end{array}$ & 15 & 13 & - & 135,588 & - & 138,750 \\
\hline \multicolumn{7}{|l|}{ Koperasi Karyawan: } \\
\hline $\begin{array}{l}\text { Murni Mapan } \\
\text { Makmur }\end{array}$ & 257 & 164 & 1 & 494,020 & $2,123,000$ & $2,123,000$ \\
\hline Fajar Cemerlang & - & - & - & - & - & - \\
\hline Linton Indra Plastics & - & - & - & - & - & - \\
\hline $\begin{array}{l}\text { Sejahtera } \\
\text { Multifreeder }\end{array}$ & & 1.770 & 3 & $27,267,476$ & $13,783,569$ & $21,064,150$ \\
\hline Univ. Yudharta & 44 & 75 & & 375,786 & 145,000 & 145,000 \\
\hline \multicolumn{7}{|l|}{ Koperasi Serba Usaha: } \\
\hline $\begin{array}{l}\text { Wahidiyah al } \\
\text { Ma'rifah }\end{array}$ & - & - & - & - & - & - \\
\hline Sumber Agung & 21 & 2 & - & 76,643 & - & - \\
\hline Sumber Rejo & 87 & 58 & - & 11,743 & 5,702 & 5,702 \\
\hline Agro Bhakti Sentosa & 25 & - & - & 382,573 & 800,400 & 800,400 \\
\hline Arta Jaya Mandiri & - & - & - & 49,480 & - & - \\
\hline Arta Barokah & - & - & - & 100,000 & - & - \\
\hline \multicolumn{7}{|l|}{ Koppas: } \\
\hline Bhakti Jaya & - & - & - & - & - & - \\
\hline
\end{tabular}


Koperasi Simpan Pinjam

Rukun Kemakmuran

Adi Guna Yatra

Koperasi Wanita:

Yasmin

25
$-\quad 39$

25 - -

36,500

PKK Kauman

39

42,985

Mandiri

25

$\begin{array}{lll}- & - & 29,000\end{array}$

Sekar Agung

Sumber Rejeki

25

27,400

Maju Bersama

25

$-$

60,000

Ayu Mekarsari

25

18,000

Kopwan RA Kartini

Other Cooperatives:

Sami Jaya

T.A. Industri Sumb.

Rejeki

BMT Arta Jaya

33,109

65,500

Umat

BMT MMU

Purwosari

Sari Bumi Agung

Sido Luhur

NA

$30 \quad 20$

77,152

$25 \quad 17$

15,087

9

Kopper Mapan Adi

Lestari

Tani Rakyat

Sejahterah

Maju Tentram

Lestari

Pilar Taruna

Dwi Jaya

Jasa Keuangan

Syariah Arsuna

\section{7}

\section{5,087}

9

$\begin{array}{ll}- & - \\ - & - \\ 36 & 24\end{array}$

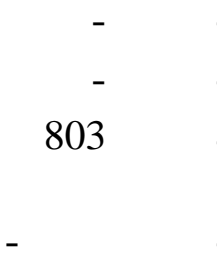

$24 \quad 16$

490,261

$15 \quad 10$

12,500

12

8 -

2,000

27,801

84,275

14,150

14,150

23

7

110,200

110,200

Bank Perkreditan Rakyat (Rural Credit Bank):

PT BPR Ardhi

Purwo

PT BPR Kraton

Suropati

PT BPR Purwosari

Anugrah

Bank Rakyat Indonesia:

BRI unit desa

Source: Various data from the Cooperative Office of Pasuruan Regency (April 2011), with modification. 
The upland area of Purwosari Subdistrict was high in institutional diversity, although financial services were provided to the local people by informal microfinance institutions, such as ROSCA, money lenders, and loans from relatives (Table 7.8). The establishment of the institutions influenced the people's behavior-for example, by forcing them to manage a balance sheet-because they were obligated to repay their credit.

\subsubsection{Islamic Microfinance InStitutions: SPECIAL APPROACHES TOWARD BetTer PERFormance}

The establishment of numerous financial institutions in the upland area created competition amongst those institutions. The better the services provided by the institutions, the more opportunities they would have to increase their reach. Hence, every MFI had their own approach to achieving better performance, such as going door-to-door, promoting their loan schemes, adopting Islamic customs to gain the trust of potential clients, or using the local culture. Still, most of the microfinance institutions conducted case studies before deciding which communities to target.

The IsMFIs were used to using Islamic approaches and customs, such as wearing Islamic clothing, going door-to-door, and providing solutions to their clients' problems. These service styles affected the institutions' performances and their clients' trust. However, the reach of IsMFIs was still limited to graduates of Islamic boarding schools and those who recognized their officials. According to Mahfudz (pers. comm.), a leader of Kayoman village in the study region, "The majority of the clients of IsMFIs in Purwosari graduated from Islamic boarding schools, or have a strong belief in Islamic teachings.”

Table 7.9: The informal education of the respondents.

\begin{tabular}{lrr}
\hline Informal Education & No. of respondents & Percent \\
\hline Pondok pesantren & 25 & 41.67 \\
Entrepreneurship & 3 & 5.00 \\
Skills & 2 & 3.33 \\
No informal education & 30 & 50.00 \\
\hline Total & 60 & 100.00 \\
\hline
\end{tabular}

$\mathrm{N}=60$. Source: fieldwork conducted in the upland area.

Table 7.9 shows that $41.67 \%$ of respondents graduated from an Islamic boarding school. It is assumed that this group had better knowledge of Islamic teachings, which includes Islamic finance, compared with those who did not study in these institutions. Fifty percent of the respondents had no informal education. 
Despite doing their best to lure more clients, the IsMFIs had problems getting those from abangan communities, which are communities that follow traditional customs or beliefs instead of Islamic teachings. The abangan communities were not yet familiar with the financial schemes provided by the Islamic microfinance institutions, which were first established in this region in April, 2006. More time as well as money is required for these institutions to persuade the abangan clients to adopt Islamic financing schemes.

\subsubsection{Conventional Microfinance Institutions: Providing Financial Services to REMOTE VILLAGES}

Conventional MFIs have been providing financial services for many years, and are experienced in obtaining and retaining a client base. However, the presence of many financial institutions in the upland area forced the MFIs to look for the best methods of maintaining a good financial performance, one of which was extending their area of operation to remote villages. The conventional institutions in the upland area used community leaders in each village as an agent that would look for potential clients. This was an effective strategy, because of the trust these remote communities would have in their leader. Nevertheless, the conventional MFIs required extra operational costs to provide credit lending to those communities. As a consequence, the clients had an interest rate attached to the loans they would receive.

\subsection{Microfinance and Poverty Alleviation in the Upland Area on Purwosari Subdistrict}

The establishment of different financial services gave alternative loans for the people in the upland area of Purwosari Subdistrict. Harvested agricultural products sometimes did not create enough profits. This was especially the case during the dry season. Through the MFIs, the people were able to keep their income at an adequate level when there were limited yields, enabling them to continue to grow crops in their land while waiting for the next harvest, before repaying their credit in monthly installments.

According to Ruben and Clercx (2003), who conducted a study in an upland area of Honduras, access to rural finance reinforces food security, thus enabling income diversification as a precondition for subsequent in-depth investment. The people in our research area had a variety of agroforestry-based vocational choices, such crop production, petty trading, and entrepreneurship. 


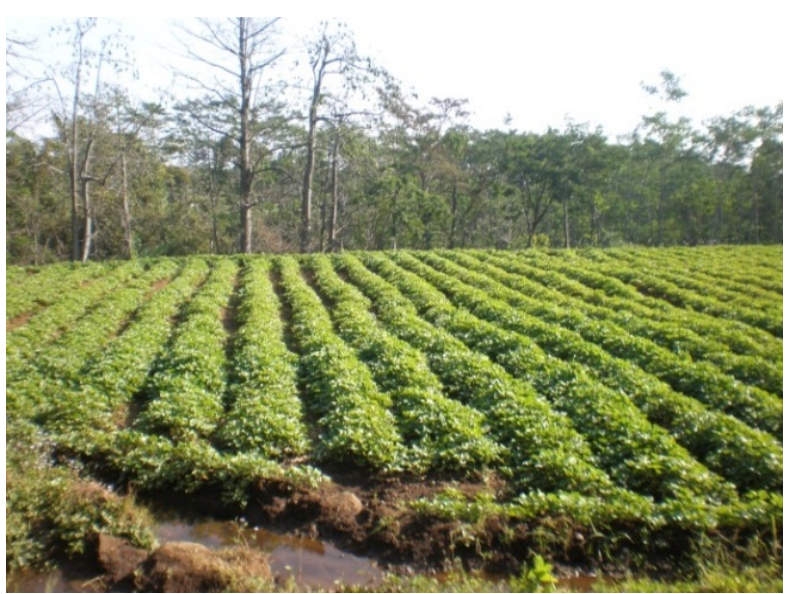

Figure 7.5: Agroforestry crops.

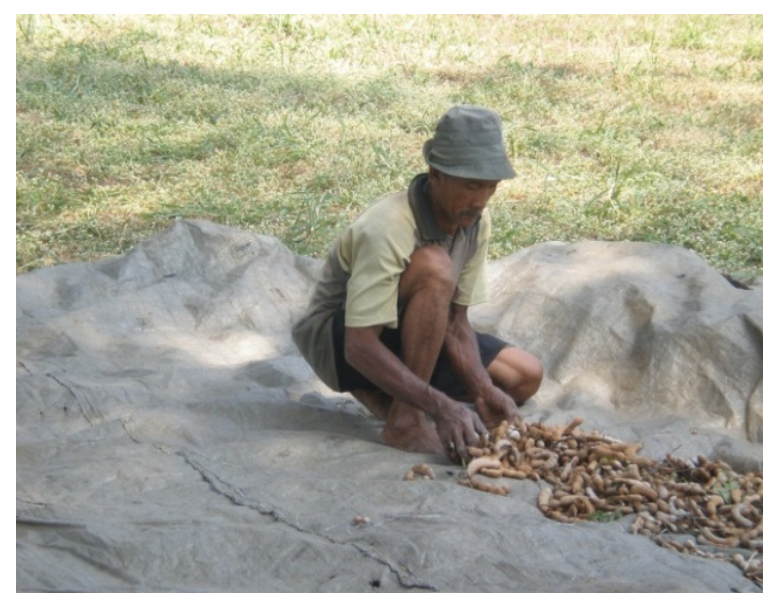

Figure 7.6: Harvesting tamarinds.

Farmers would usually go to their field in the morning until midday. After a period of rest, they continued to take care of their crops until 16:00 or 17:00. While off-farm activities were also generally conducted between morning and afternoon, those who worked in factories would sometimes set up shifts to do the latter at night.

Table 7.10: Monthly household income and expenditure.

\begin{tabular}{lrr}
\hline Indicators & No. of respondents & Percent \\
\hline Income per month (Rupiahs): & 1 & \\
250,001-500,000 & 1 & 1.67 \\
$500,001-750,000$ & 1 & 1.67 \\
$750,001-1,000.000$ & 5 & 1.67 \\
$1,000,001-1,500,000$ & 8 & 8.33 \\
1,500,001-2,000,000 & 35 & 13.33 \\
2000,001-5,000,000 & 9 & 58.33 \\
$>$ 5,000,000 & & 15.00 \\
Expenditure per month (Rupiahs): & 1 & \\
250,000 or less & 0 & 1.67 \\
250,001-500,000 & 5 & 0.00 \\
$500,001-750,000$ & 7 & 8.33 \\
$750,001-1,000,000$ & 13 & 21.67 \\
1,000,001-1,500,000 & 14 & 23.33 \\
$1,500,001-2,000,000$ & 19 & 31.67 \\
2,000,001-5,000,000 & 1 & 1.67 \\
$>$ 5,000,000 & & \\
\hline
\end{tabular}

$\mathrm{N}=60$. Source: Fieldwork conducted in the upland area.

Table 7.10 shows that the majority of respondents (58.33\%) had incomes of Rp 2,000,0005,000,000, followed by the 15\% who earned more than Rp 5,000,000 and 13.3\% who earned Rp 1,500,001-2,000,000. These percentages suggest that the households of our respondents in the upland area of Purwosari Subdistrict had good welfare. In general, the people who had monthly 
incomes exceeding Rp 2,000,000 had to provide collateral when applying for a credit scheme with an MFI. When the head of a household earned less than Rp 1,500,000, as was the case for $13.33 \%$ of the respondents, receiving a soft loan or qard al hasan was possible, and giving valuable objects as collateral was not required.

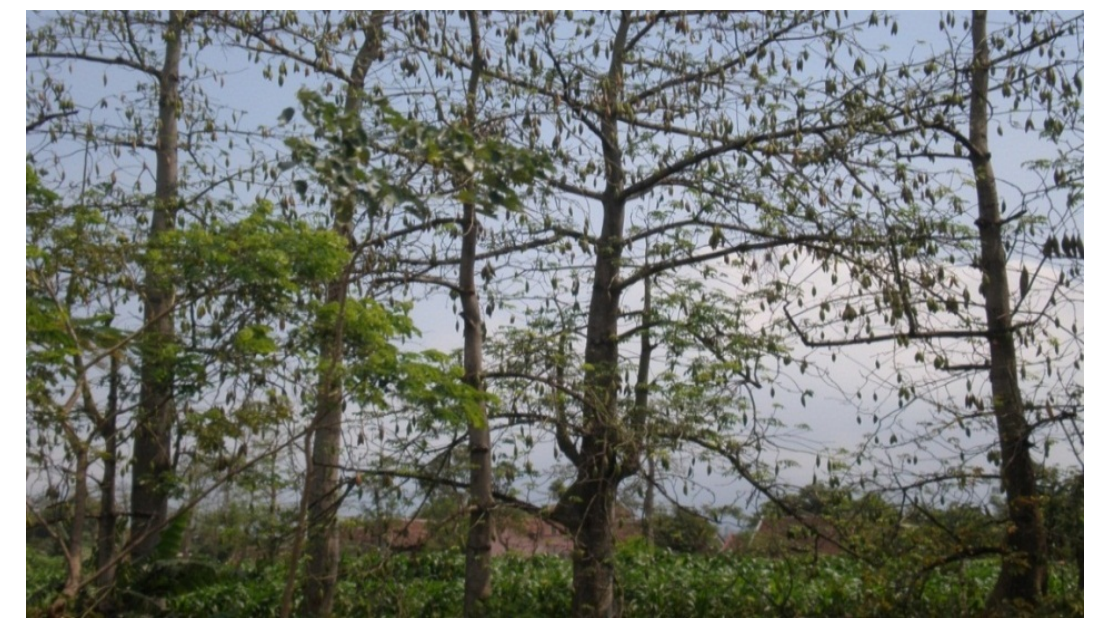

Figure 7.7: Kapok trees.

The highest percentage of respondents (31.7\%) spent Rp 2,000,000-5,000,000 per month (Table 7.10). They were followed by those with expenditures of Rp 1,500,000-2,000,000 (23.3\%). Meanwhile, households with expenditures of Rp 1,000,000-1,500,000 and less than Rp $1,000,000$ accounted for $21.7 \%$, each. Therefore, most of the respondents $(43.4 \%)$ had expenditures lower than Rp 1,500,000, contrasting with the $13.4 \%$ who had incomes lower than Rp 1,500,000. This disparity may be related to family size (Table 7.11).

Table 7.11: Cross tabulation between monthly household income and expenditure.

\begin{tabular}{lrrrrrrr}
\hline Cross tabulation & \multicolumn{7}{c}{ Monthly expenditure (000 Rupiahs) } \\
\hline Main and side & $250,1-$ & $500,1-$ & $750,1-$ & $1,000,1-$ & $1,500,1-$ & $2,000,1-$ & $>$ \\
income (Rupiahs) & 500 & 750 & 1,000 & 1,500 & 2,000 & 5,000 & 5,000 \\
\cline { 2 - 8 } $250,001-500,000$ & 0 & 0 & 0 & 0 & 1 & 0 & 0 \\
$500,001-750,000$ & 0 & 0 & 0 & 1 & 0 & 0 & 0 \\
$750,001-1,000,000$ & 0 & 0 & 1 & 0 & 0 & 0 & 0 \\
$1,000,001-1,500,000$ & 0 & 1 & 2 & 1 & 0 & 1 & 0 \\
$1,500,001-2,000,000$ & 0 & 3 & 1 & 2 & 1 & 1 & 0 \\
$2,000,001-5,000,000$ & 1 & 1 & 3 & 8 & 12 & 10 & 0 \\
$>5,000,000$ & 0 & 0 & 0 & 1 & 0 & 7 & 1 \\
\hline Total & 1 & 5 & 7 & 13 & 14 & 19 & 1 \\
\hline
\end{tabular}

$\mathrm{N}=60$. Source: fieldwork conducted in the upland area.

Twelve respondents (18.3\%) had incomes Rp 2,000,001-5,000,000 while having expenditures of Rp 1,500,001-2,000,000 (Table 7.11). Ten respondents (16.67\%) earned Rp 2,000,001- 
5,000,000 while spending Rp 2,000,001-5,000,000. These data indicate that a large number of people were able to balance their income and expenditures. There were a number of respondents whose expenditures greatly exceeded their income: one respondent (1.67\%) who earned Rp 250,001-500,000 while spending Rp 1,500,001-2,000,000, one (1.67\%) who earned Rp 500,001-750,000 while spending Rp 1,000,001-1,500,000, one (1.67\%) who earned Rp 1,000,001-1,500,000 while spending Rp 2,000,001-5,000,000, and one (1.67\%) who earned Rp 1,500,001-2,000,000 while spending Rp 2,000,001-5,000,000. These data suggest that there was a poverty problem amongst some of the clients. The poverty alleviation program provided by the central government might be able to empower them out of poverty traps.

Table 7.12: Cross tabulation between family size and income.

\begin{tabular}{lllllll}
\hline Main and side income & \multicolumn{7}{l}{ Number of people per household } \\
\cline { 2 - 7 } (Rupiahs) & 2 & 3 & 4 & 5 & 6 & 7 \\
\hline $250,001-500,000$ & 0 & 1 & 0 & 0 & 0 & 0 \\
$500,001-750,000$ & 0 & 0 & 1 & 0 & 0 & 0 \\
$750,001-1000,000$ & 0 & 1 & 0 & 0 & 0 & 0 \\
$1,000,001-1,500,000$ & 1 & 2 & 2 & 0 & 0 & 0 \\
$1,500,001-2,000,000$ & 0 & 4 & 3 & 0 & 0 & 1 \\
$2,000,001-5,000,000$ & 2 & 8 & 18 & 5 & 2 & 0 \\
$>5,000,000$ & 0 & 2 & 3 & 3 & 1 & 0 \\
\hline Total & 3 & 18 & 27 & 8 & 3 & 1 \\
\hline
\end{tabular}

$\mathrm{N}=60$. Source: fieldwork conducted in the upland area.

Eighteen households (30\%) with incomes of Rp 2,000,000-5,000,000 had four family members, while eight (13.33\%) had three family members. The one household (1.67\%) with an income of Rp 250,001-500,000 had three family members, while the one household (1.67\%) to earn Rp 500,001-750,000 had four members. In addition, a single household (1.67\%) with an income of Rp 1,500,001-2,000,000 had to cover expenditures for seven family members, suggesting that some of the respondents had little family planning success. 
Box 7.1: Microfinance and poverty alleviation.

A number of clients of microfinance institutions were interviewed to understand how MFIs affected poverty alleviation in the area. The first client was $M$. Sholeh, who joined a conventional MFI in 2007 and received credit as additional capital for his business selling vegetables and fish, which was established in 2006. Having applied for credit six times, he made repayments in installments once a week, with $2 \%$ in interest added. Regarding his experience in dealing with MFIs, he said, "My business's profits have increased, enabling me to afford better education for my children, as well as providing better welfare for them. I am even planning on hiring an employee to help me with my business."

The second client was Samsudi, a 43-year-old who joined a conventional microfinance institution in 1996. He started growing rice and soybeans in 1990, because he considered agriculture to be low risk and high reward. He received credit from the conventional MFI eight times and about $90 \%$ of his startup capital was from the institution. Speaking on the role of microfinance on his family welfare, he said, "I used to have problems purchasing subsistence goods for my family, but after joining the MFI, I received enough profit to have money deposited in a bank. I also had enough surplus capital to buy more farmland to rent to others."

Mustaqim, the third client, joined a conventional MFI in 2009, having started a crop production business ten years earlier. He received credit five times, and said that the MFIs with which he dealt were relatively easy and simple, because he was not required to visit their offices. On his institution, he said, "After receiving credit, my business's profits increased. This allowed me to enlarge my land area and see an increase in revenues."

The fourth client, Moh Fauzan, a man with five family members, received financing from an Islamic MFI since 2002. His business involved farming and trading second-hand motorcycles, which started in 1996. Regarding poverty after joining MFIs, he said, "The profits of my business increased after I received financing from the Islamic MFI. I had a profit of around Rp 6,000,000, from Rp 2,000,000 in financing. My business has thrived because of these profits."

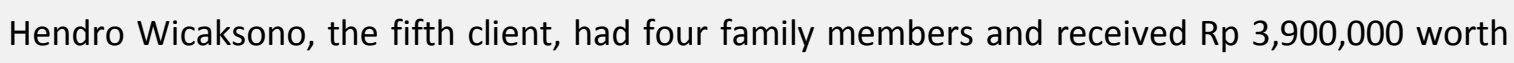
of financing from an Islamic MFI. After being fired from his old job in a factory, he started selling fruit juice (cincau) in 2008, intending to cover his family's daily needs. Regarding his family's welfare, he said, "The welfare of my family increased after I received financing from the Islamic MFI, and my business had between Rp 600,000 and Rp 1,200,000 in profits."

In general, the MFIs in the upand area had a positive effect on poverty alleviation within the region, since the people were able to use the extra money to balance their incomes with their expenditures, and be provided with capital for their businesses. However, there were respondents with low family incomes and high expenditures. The integrated government's poverty alleviation 
program should be directed toward these people. Kaushal and Kala (2005) found that close interaction between the government and its people through MFIs increases the chance of sustainable development succeeding.

\subsection{Microfinance and Environmental Awareness}

Environmentally unsafe or unfriendly businesses have a negative impact on the environment. MFIs, by their ability to enable the creation or development of businesses, may provide significant contributions to mitigating environmental degradation. Two examples are setting conditions for credit applications and collaborating with non-governmental organizations (NGOs) to provide training and other forms of social assistance to clients. As Rouf (2012a) advises, through the use of loans, MFIs can provide incentives to businesses that reduce or recycle waste, thus contributing to the reduction of environmental degradation. In addition to MFIs, the government can also provide its own incentives to businesses or entrepreneurs, while NGOs can contribute by providing training.

Table 7.13: Training on environmental issues provided by the MFIs.

\begin{tabular}{lrr}
\hline $\begin{array}{l}\text { Do MFIs provide training on } \\
\text { environmental issues? }\end{array}$ & No. of respondents & Percent \\
\hline Yes & 7 & 11.67 \\
No & 20 & 33.33 \\
Don't know & 33 & 55.00 \\
\hline Total & 60 & 100.00 \\
\hline
\end{tabular}

$\mathrm{N}=60$. Source: fieldwork conducted in the upland area.

Table 7.13 shows that 55\% of respondents did not know whether MFIs provide training on environmental issues, while $33.33 \%$ claimed to have not received any training. Only $11.67 \%$ reported receiving training. Based on these percentages, the low environmental awareness in the upland area may have been caused or enabled by the absence of training on environmental issues. A lack of time, money, and human resources were considered by the MFIs to be the greatest obstacles to providing training on environmental issues to their clients. One solution for lessening the cost of training may be for MFIs to give loans to eco-friendly businesses only, or at a greater number than to those that are not eco-friendly.

Although it was risky for MFIs to finance eco-friendly businesses, they had other opportunities to maintain the environment through various social activities, such as financially supporting communities’ environmental projects, or organizing their clients to work together. 
Table 7.14: Social programs provided by the MFIs.

\begin{tabular}{lrr}
\hline Do MFIs provide social programs? & No. of respondents & Percent \\
\hline Yes & 8 & 13.33 \\
No & 19 & 31.67 \\
Don't know & 33 & 55.00 \\
\hline Total & 60 & 100.00 \\
\hline
\end{tabular}

$\mathrm{N}=60$. Source: fieldwork conducted in the upland area.

The majority of respondents (55\%) reported that they did not know whether MFIs provide social programs on environmental awareness, while 31.67\% said that none existed (Table 7.14). Only $13.33 \%$ of the respondents reported that the MFIs provided social programs. These percentages indicate that the MFIs' environmental programs in the region were still small-scale. $\mathrm{H}$. Suud Effendi (pers. comm.), one of the village leaders in the research area, said:

We have had programs to clean the plastic waste within our village, and the MFIs supported us by supplying around Rp 50,000 to Rp 100,000. That amount was very low, and insufficient for maintaining the environment. It would be better if the MFIs helped us by providing things such as trash cans in which to throw the plastic waste.

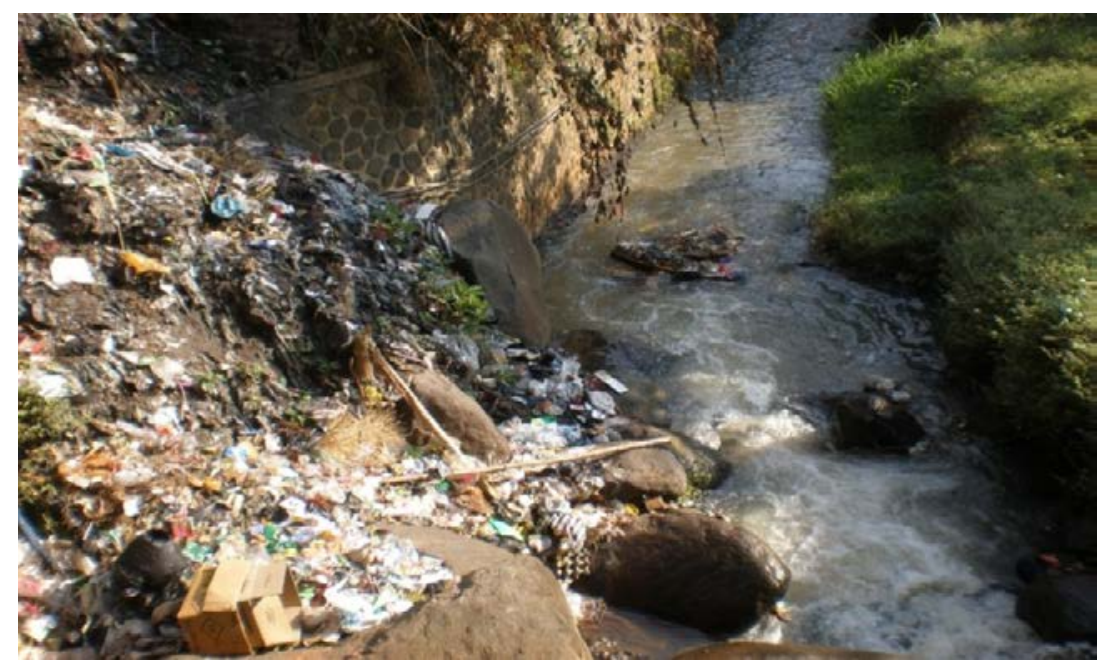

Figure 7.8: Societal garbage on a riverbank, illustrating the environmental ignorance of the local people.

The people in the upland area were used to defecating in the same river that was used for daily activities. Despite this, the communities felt they were using the correct methods to maintain the environment. 
Table 7.15: Problems faced by the respondents.

\begin{tabular}{lrr}
\hline $\begin{array}{l}\text { Do you perceive any problems in } \\
\text { maintaining the environment? }\end{array}$ & No. of respondents & Percent \\
\hline Yes & 10 & 16.67 \\
No & 50 & 83.33 \\
\hline Total & 60 & 100.00 \\
\hline
\end{tabular}

$\mathrm{N}=60$. Source: fieldwork conducted in the upland area.

A significant majority of the respondents (83.33\%) reported that they did not perceive any problems in maintaining the environment, suggesting that there was a perception amongst the communities that they had a safe and healthy environment. The remaining respondents, $16.67 \%$, reported having problems, such as not being given clear regulations on environmental subjects or adequate infrastructure. Governmental environmental policies that combat these problems might help to reduce the environmental degradation. According to a study in the state of Tamil Nadu, India, by Jha and Bawa (2006), of 97 businesses that were provided with loans, 35 eventually failed, and only 29 of the successful businesses had repaid their loans. Furthermore, the authors found that one-third of the businesses negatively impacted the environment, and none had a positive impact. Merely providing loans may enable client communities to overcome economic problems, but that may not be the case with environmental problems. Along with MFIs providing training and social programs, governmental policies that combat the lack of regulation and infrastructure, and, as the authors state, the "input of traditional as well as scientific knowledge”, may reduce the environmental degradation in the upland area.

Table 7.16: Reaction of the community to environmental damage.

\begin{tabular}{lrrr}
\hline $\begin{array}{l}\text { How would you react to damage to your } \\
\text { environment? }\end{array}$ & No. of respondents & Percent \\
\hline $\begin{array}{l}\text { I will report to the village leader or village } \\
\text { organizations. }\end{array}$ & 11 & 18.33 \\
$\begin{array}{l}\text { I will reduce the environmental damage to the } \\
\text { best of my ability. }\end{array}$ & 30 & 50.00 \\
$\begin{array}{l}\text { I will invite my neighbor(s) to help me improve } \\
\text { the environment's condition. }\end{array}$ & 2 & 3.33 \\
Other. & 60 & 100.00 \\
\hline Total
\end{tabular}

$\mathrm{N}=60$. Source: fieldwork conducted in the upland area.

Half of the respondents (50\%) reported that if they encountered environmental damage they would try to invite their neighbor(s) to help them reduce the environmental degradation, while 28.33\% would attempt to reduce it alone to the best of their ability. These percentages indicate a 
high level of environmental responsibility felt by the people of the upland area. Consequently, it is likely that combining greater knowledge in environmental preservation with the active involvement of locals would improve environmental sustainability. A minority group (18.33\%), however, would report to a village leader, only, suggesting that a minority of the region would prefer to be only passively involved in environmental preservation.

Box 7.2: Microfinance institution clients on environmental issues.

In-depth interviews with the clients of some MFIs were conducted to understand their effects on environmental awareness in the upland area of Purwosari Subdistrict. The first client, Imam Mahdi, was 46 years old. He joined an Islamic MFI in 2006, hoping to receive financing for his agriculture business. His most recent loan was for $R p 4,000,000$, and was to be paid back in six months. Regarding environmental issues, he said, "I don't think my agriculture business damages the environment. However, I will report to the village official if I see that the environment is polluted or damaged." He also added that he did not "have significant behavior changes on environmental issues after joining the Islamic MFI."

The second client was Sukir, who had four family members and joined an Islamic microfinance institution in 2001. He started a crop production business in 1990. On environmental issues after joining an Islamic MFI, he said, "Because I reduced the amount of chemical fertilizer in my crops, my business is eco-friendly. But, if the environment is polluted, I will ask my neighbors to help me improve it." On whether his environmental awareness has changed since joining a MFI, he said, "I have better environmental awareness after joining the Islamic MFI, because of the Islamic culture and attitude of its officials."

$\mathrm{H}$ Yusuf, the third client, had five family members and had been receiving financing from an Islamic MFI since 2007 for additional capital for his farm, which opened in 1985 and grew mainly corn. When asked about how he would deal with environmental damage, he said, "I will inform my neighbor(s) and ask them to help me reduce the damage, even though there is no training support from my Islamic MFI on environmental issues."

The fourth respondent, Abdul Kodir, had four family members and joined a conventional MFI to get additional capital for his agriculture business in 2005. On the environment, he said, "My business has no negative impacts on the environment. However, although the MFI's officials often give advice, I will inform the village officials when the environment in this area is polluted or damaged."

Suparman, the fifth client, with three family members, had been a member of a conventional MFI since 2005. He inherited his agriculture business from his parents in 1997. Regarding environmental damage, he said, "If the environment is damaged and polluted, I will inform the village officials, although they usually ask us to reduce the damage together with other neighbor(s)." 
The livelihoods of our respondents in the upland area of Purwosari Subdistrict were based on agriculture, manufacturing, providing services, and trading. These livelihoods had direct effects on the future of the environment around them. Regarding environmental awareness, most of them had the initiative to either improve the environment themselves or, more commonly, with their neighbors. In spite of that, however, there was still limited environmental awareness amongst our respondents.

As members of microfinance institutions, most of our respondents expected capacity building from their institutions, such as social and mentoring programs. However, because of the cost of these programs, the MFIs preferred to only provide advice for problems like environmental preservation. Because of limited environmental knowledge on the part of their officials, as well as the little financial support they provide to the area for environmental preservation, the MFIs appeared to have a low effect on environmental awareness.

The MFIs might have a more meaningful impact if they allocate credit based on local resources and conditions, and require their clients to have eco-friendly businesses, and encourage their clients to create community-based groups dedicated to preserving the environment. Additionally, the MFIs could initiate collaborative efforts with NGOs and the government, as well as the local people, themselves. Mazzucato and Niemeijer (2002) found that adaptation to local conditions had a positive impact on environmentally sustainable land use. 


\section{The Effects of Islamic and Conventional MFIs on Poverty Alleviation and Environmental Awareness: Geographical and MFI Type Comparisons}

In this chapter, we provide a comparative analysis of the different research areas' microfinance institutions' (MFI) effects on poverty alleviation and environmental awareness, comparing the three areas that were separated based on geography (lowland, coastal, and upland), and the two different types of microfinance institution (Islamic and conventional).

We interviewed clients of the MFIs in three different areas in Pasuruan Regency. The livelihoods of each area's inhabitants differed based on their specific geography: the lowland area had fertile land that enabled heavy farming, the coastal area's proximity to the ocean made for the exploitation of marine resources as the primary source of income, and the upland area saw mainly agroforestry-based livelihoods.

There were various MFIs providing financial services to the people in our research areas. The institutions generally provided financial services based on the economic needs of each individual community.

\subsection{MFIs in the Three Research Areas: Geographical Comparisons}

\subsubsection{CHARACTERISTICS OF MFI CLIENTS IN THE THREE RESEARCH AREAS}

In order to fully understand the impact of microfinance in the three research areas, greater detail on the individual characteristics of their inhabitants was required. This data is presented in Table 8.1. There were some similarities between all three regions, such as sex, age, marital status, and religion, as well as some differences, such as education level, occupation, and income. 
Table 8.1: Characteristics of the heads of household.

\begin{tabular}{|c|c|c|c|}
\hline \multirow{2}{*}{ Characteristics } & \multicolumn{3}{|c|}{ Geographical Area } \\
\hline & Lowland & Coastal & Upland \\
\hline \multicolumn{4}{|l|}{ Sex (\%): } \\
\hline Male & 96.67 & 98.33 & 95.00 \\
\hline Female & 3.33 & 1.67 & 5.00 \\
\hline \multicolumn{4}{|l|}{ Age: } \\
\hline Mean & 44.10 & 40.05 & 40 \\
\hline Minimum & 25 & 21 & 23 \\
\hline Maximum & 63 & 60 & 61 \\
\hline \multicolumn{4}{|l|}{ Marital status (\%): } \\
\hline Unmarried & 0.00 & 1.67 & 6.67 \\
\hline Married & 98.33 & 96.67 & 86.67 \\
\hline Widow/widower & 1.67 & 1.67 & 6.67 \\
\hline \multicolumn{4}{|l|}{ Religion (\%): } \\
\hline Islam & 100.00 & 100.00 & 100.00 \\
\hline \multicolumn{4}{|l|}{ Able to write (\%): } \\
\hline No & 1.67 & 1.67 & 0.00 \\
\hline Yes & 98.33 & 98.33 & 100.00 \\
\hline \multicolumn{4}{|l|}{ Education level (\%): } \\
\hline Never attended school & 3.33 & 1.67 & 0.00 \\
\hline Some elementary school & 13.33 & 1.67 & 8.33 \\
\hline Completed elementary school & 36.67 & 33.33 & 36.67 \\
\hline Attended junior high school & 5.00 & 1.67 & 3.33 \\
\hline Completed junior high school & 20.00 & 16.67 & 18.33 \\
\hline Attended senior high school & 1.67 & 1.67 & 1.67 \\
\hline Completed senior high school & 11.67 & 36.67 & 18.33 \\
\hline Attended academy/university & 8.33 & 6.67 & 13.33 \\
\hline \multicolumn{4}{|l|}{ Informal Education (\%): } \\
\hline No & 51.67 & 75.00 & 68.33 \\
\hline Yes & 48.33 & 25.00 & 31.67 \\
\hline \multicolumn{4}{|l|}{ Main occupation (\%): } \\
\hline Self-employed in agriculture & 38.33 & 35.00 & 58.33 \\
\hline Self-employed in off-farm enterprises & 41.67 & 50.00 & 20.00 \\
\hline Government employee & 3.33 & 1.67 & 5.00 \\
\hline Casual worker & 8.33 & 6.67 & 1.67 \\
\hline Salaried worker in non-agriculture & 8.33 & 6.67 & 15.00 \\
\hline \multicolumn{4}{|l|}{ Family size: } \\
\hline Mean & 4.03 & 3.58 & 3.88 \\
\hline Minimum & 2 & 2 & 2 \\
\hline Maximum & 6 & 6 & 7 \\
\hline \multicolumn{4}{|l|}{ Average monthly income (Rp): } \\
\hline Average & $2,563,750$ & $1,517,500$ & $1,795,000$ \\
\hline Minimum & 300,000 & 250,000 & 600,000 \\
\hline Maximum & $14,000,000$ & $6,000,000$ & $10,000,000$ \\
\hline
\end{tabular}

$\mathrm{N}=60$. Source: fieldwork. 
The vast majority of the heads of household were male, married, and literate. Additionally, the percentage of people who completed elementary school was similar, along with the mean family size, while $100 \%$ of the respondents in each area were Muslim. While the majority of the heads of household in all three regions had no informal education, the percentage of people in the lowland area (51.67\%) was considerably lower than those in the coastal and upland areas (75\% and 68.33\%, respectively). These data conflict with those in Chapters 5 (Table 5.9), 6 (Table 6.9), and 7 (Table 7.8), where between $50 \%$ and $75 \%$ of our respondents had informal educations. The highest percentage was found in the lowland area (75\%), followed by the coastal area (56.67\%) and upland area (50\%). The reason for this is because a small minority (between two and 15) of the respondents was not the head of their household at the time of the interview, and would answer on the head's behalf, which resulted in an extra set of answers; two in the upland area, 10 in the coastal area, and 15 in the lowland area. These answers (i.e. those pertaining to the respondents, themselves) were used in Chapters 5, 6, and 7, while their answers on behalf of their household's head is used here, in Table 8.1. Accounting for some of the incongruity between these two sets of data, two (100\%) of the respondents in the upland area, seven (70\%) in the coastal area, and 10 (66.67\%) in the lowland area had informal educations.

The greatest differences between the three areas were in education, main occupation, and wealth. Regarding education, $13.33 \%$ of our respondents in the lowland area attended elementary school, compared with the $8.33 \%$ and $1.67 \%$ in the upland and coastal areas, respectively; $36.67 \%$ of the respondents in the coastal area completed senior high school, compared with the $18.33 \%$ and $11.67 \%$ in the upland and lowland areas, respectively; and $13.33 \%$ of our respondents in the upland area attended an academy or university, compared with the mere $8.33 \%$ and $6.67 \%$ in the lowland and coastal areas, respectively. There was a contrast between the lowland and coastal areas and the upland area in terms of the main occupations of the inhabitants. While the majority of the respondents in the upland area were self-employed in agriculture, this was only the case for a smaller number of people in the lowland and coastal areas. Conversely, most of the respondents in the lowland and coastal areas were self-employed in off-farm enterprises $(41.67 \%$ and $50 \%$, respectively), whereas only $20 \%$ in the upland area were self-employed in off-farm enterprises. The greatest disparity, however, was in monthly income. The largest monthly income was Rp 14,000,000 and occurred in the lowland area; the next-largest, occurring in the upland area, was 73.33\% less, Rp 10,000,000. With that disparity, the average monthly income in the lowland area was correspondingly greater than those in the coastal and upland areas. 


\subsubsection{The EFFECT OF MFIs ON POVERTy AlLEVIATION}

The livelihoods of the communities in the three research areas were affected by the introduction and presence of the conventional MFIs and Islamic MFIs (IsMFIs). Through the MFIs' capital injection in the form of loans, they were able to generate extra income. Furthermore, they had opportunities to balance their incomes with their expenditures using those loans, particularly when they were faced with unpredictable changes to their environment that impacted their sources of income, such as the flooding in the lowland area or the movement of fish populations in the coastal area. Hence, MFIs were considered to have a positive effect on the poverty alleviation of their clients.

Besides loans from MFIs, other factors affecting the development of the clients' businesses included the age of their business and its number of employees. Age of business impacted capital and savings, while number of employees indicated the level of investment. These factors consequently affected income and welfare.

Table 8.2: Age of business.

\begin{tabular}{lrrr}
\hline \multirow{2}{*}{ Age of business } & \multicolumn{3}{c}{ Geographical area } \\
\cline { 2 - 4 } & Lowland (\%) & Coastal (\%) & Upland (\%) \\
\hline$<5$ years & 21.67 & 33.3 & 26.67 \\
$5-10$ years & 21.67 & 28.3 & 35.00 \\
$10-15$ years & 16.67 & 15.00 & 10.00 \\
$>15$ years & 33.33 & 15.00 & 21.67 \\
Other & 6.67 & 10.00 & 6.67 \\
\hline Total & 100.00 & 100.00 & 100.00 \\
\hline
\end{tabular}

$\mathrm{N}=180$ (60 per area). Source: fieldwork.

Table 8.2 shows that the coastal area had the most respondents with businesses less than five years old, with $33.33 \%$, followed by the upland and lowland areas, with $26.67 \%$ and $21.67 \%$, respectively. While the coastal area had the highest incidence of new businesses, it was the exact opposite for businesses over 15 years old. The lowland area had the highest percentage (33.33\%), followed by the upland and coastal areas (21.67\% and 15\%, respectively). The upland area, middling in the new and old business categories, dominated the 5-10 years category, with $35 \%$, followed by the coastal area (28.33\%) and lowland area (21.67\%). With the coastal and upland areas sharing the highest percentage of businesses less than 10 years old, and the lowland area dominating in businesses older than 10, these data suggest that the lowland area saw earlier economic development than the other two areas. This may be because of its proximity to Pasuruan, the largest city in the surrounding area, which looks to Kraton Subdistrict for some of 
its food supply, enabling it to more easily sell its agricultural products. Another factor may also be governmental policies favoring regions whose source of income is based on farming.

Although our respondents generally involved their family members in their businesses, some preferred to hire other people to assist them (Table 8.3). The farmers in the lowland area were used to hiring a large number of people for a short time to plant or harvest their rice, and fishermen invited other people to catch fish with them, while the people in the upland area would hire a small group of people for the kapok harvest. In general, more people were hired when businesses improved.

Table 8.3: Number of employees.

\begin{tabular}{lrrr}
\hline \multirow{2}{*}{ Number of employees } & \multicolumn{3}{c}{ Geographical area } \\
\cline { 2 - 4 } & Lowland (\%) & Coastal (\%) & Upland (\%) \\
\hline$<5$ people & 53.33 & 63.33 & 65.00 \\
5-10 people & 15.00 & 21.67 & 21.67 \\
10-20 people & 11.67 & 5.00 & 6.67 \\
$>$ 20 people & 13.33 & 1.67 & 0.00 \\
Other & 6.67 & 8.33 & 6.67 \\
\hline Total & 100.00 & 100.00 & 100.00 \\
\hline
\end{tabular}

$\mathrm{N}=180$ (60 per area). Source: fieldwork.

In each region, the majority of businesses had fewer than five people (Table 8.3). This was led by the upland area (65\%), then the coastal area (63.33\%), and finally, the lowland area (53.33\%). In general, the people with a small number of employees would be the ones who preferred to get their family members to assist. This was especially the case in the lowland and coastal areas. Just as with business age, while the lowland area had the lowest percentage of businesses with fewer than five employees, it had the highest percentage of businesses with 20 employees or more (13.33\%), followed by the coastal area (1.67\%), and upland area, which had zero. It also similarly had the highest percentage of businesses with 10-20 employees, with $11.67 \%$, followed by the upland and coastal areas, with $6.67 \%$ and 5\%, respectively. These data indicate that, while the majority of people in the lowland area had less than five employees, it still surpassed the other two regions in terms of business size, which is an indicator of the strength of an economy. The coastal and upland areas shared dominance in businesses with 5-10 employees, with 21.67\% each, with the lowland area again trailing with $15 \%$. 
Table 8.4: MFIs’ effects on business development.

\begin{tabular}{lrrr}
\hline Does microfinancing/loaning & \multicolumn{3}{c}{ Geographical area } \\
\cline { 2 - 4 } $\begin{array}{l}\text { have a positive effect on the } \\
\text { development of your business? }\end{array}$ & Lowland (\%) & Coastal (\%) & Upland (\%) \\
\hline Yes & 85.00 & 85.00 & 75.00 \\
No & 15.00 & 15.00 & 25.00 \\
\hline Total & 100.00 & 100.00 & 100.00 \\
\hline $\mathrm{N}=180$ (60 per area). Source: fieldwork. & &
\end{tabular}

A significant majority of the respondents in all three regions believed that microfinance or loans positively affected the development of their businesses (Table 8.4). Both the lowland and coastal areas had the most respondents who reported in the affirmative, with $85 \%$ each, followed by the upland area, with $75 \%$. These percentages indicate that the MFIs had a major positive effect on the businesses of their clients, and that those in the lowland and coastal areas had slightly more positive impacts than those in the upland area. However, that $25 \%$ of the respondents in the upland area (and 15\% in both the lowland and coastal areas) still reported that their MFI did not have any effect on the development of their business suggests that the MFIs still needed more time to develop and provide further financial services to their clients.

Table 8.5 Business development affecting family welfare.

\begin{tabular}{lrrr}
\hline Does the development of your & \multicolumn{3}{c}{ Geographical area } \\
\cline { 2 - 4 } business impact the welfare of & Lowland (\%) & Coastal (\%) & Upland (\%) \\
your family? & 90.20 & 98.04 & 95.56 \\
\hline Yes & 9.80 & 1.96 & 4.44 \\
No & 100.00 & 100.00 & 100.00 \\
\hline Total &
\end{tabular}

$\mathrm{N}=147$ (51 in lowland, 51 in coastal, 45 in upland). Source: fieldwork.

Table 8.5 shows that while the vast majority of all the regions' respondents reported that the development of their business had an impact on their family welfare, there was still some variation between the three areas, with the highest percentage (98.04\%) being found in the coastal area, followed by the upland area (95.56\%) and lowland area (90.20\%). These data indicate that in affecting the development of their clients' businesses, the MFIs played a role in increasing their families’ welfare, as well.

When the clients saw a surplus of income, our respondents would either re-invest in their business or spend the money on their family or home. The distribution of their money is presented in Table 8.6. 
Table 8.6: Item distributions impacted from business development.

\begin{tabular}{lrrr}
\hline \multirow{2}{*}{ Item distribution } & \multicolumn{3}{c}{ Geographical area } \\
\cline { 2 - 4 } & Lowland (\%) & Coastal (\%) & Upland (\%) \\
\hline House renovation & 21.74 & 10.00 & 20.93 \\
Increased household goods & 19.57 & 6.00 & 13.95 \\
Increased employees & 4.35 & 0.00 & 4.65 \\
Increased business size & 50.00 & 84.00 & 55.81 \\
Other & 4.35 & 0.00 & 4.65 \\
\hline Total & 100.00 & 100.00 & 100.00 \\
\hline
\end{tabular}

$\mathrm{N}=139$ (46 in lowland, 50 in coastal, and 43 in upland). Source: fieldwork.

Business re-investment for the purpose of increasing size was largely the preferred method of surplus income allocation amongst the respondents in all three research areas. This was the case with the vast majority of respondents in the coastal area (84\%), and less so those in the upland (55.81\%) and coastal (50\%) areas. Some of the ways in which the respondents would re-invest in their business to increase its size was to rent or buy additional plots of land for further agricultural production, renting or buying extra boats, or acquiring tools to process their goods themselves for increased net profits.

The second-highest priority amongst the respondents was house renovations, with the highest being found in the lowland area (21.74\%), followed by the upland area (20.93\%) and coastal area (10\%). A slightly smaller number preferred to purchase household goods, with the ranking of the areas mirroring that of house renovations. The lowland area led with $19.57 \%$, followed by the upland and coastal areas, with $13.95 \%$ and 6\%, respectively. Additionally, a small percentage of respondents in the lowland (4.35\%) and upland (4.65\%) areas spent their surplus incomes on things we have categorized as "other", which is the use of surplus income for other purposes, such as higher education for their children, pilgrimages, starting a side business, or purchasing motorcycles. These data indicate that the respondents in the three areas were more focused on the future of their businesses than their individual wants. Afrane (2002) reviewed two studies on the impact of microfinance intervention; one in Ghana and one in South Africa. He found that microfinancing resulted in increased business incomes, which in turn affected the poverty alleviation of the business owners. These MFI clients would have improved housing, education, food consumption, and health care.

In general, the presence of MFIs in the lowland, coastal, and upland areas affected the performance of their clients' businesses, as indicated by the improvement of their businesses, family welfare, and household expenditures. However, as the lowland area also had the lowest 
percentage of respondents spending their surplus income on increasing the size of their business, it is likely that the people of this region were less interested in business development than those in the other two research areas. Although attention should be paid to the upland and coastal areas, as well, policies focusing on economic development and investment should target the people of the lowland area, in particular.

\subsubsection{THE EFFECT OF MFIS ON ENVIRONMENTAL AWARENESS}

By and large, the MFIs in our research areas focused their business services on providing credit and savings schemes. However, as their reach extended to remote areas, they had an opportunity to have a wide-ranging effect on environmental awareness, especially if, as Allet and Hudon (2013) argue, they were large MFIs or registered as banks. A number of MFIs had certain environmental prerequisites before approving loans. Sometimes, the MFIs also conducted training and social programs to increase environmental awareness and thus reduce environmental degradation in a specific region. Respondents were asked about their awareness of specific environmental issues (Table 8.7).

Table 8.7: Clients from different regions' knowledge of specific environmental issues.

\begin{tabular}{lrrrrrr}
\hline \multirow{2}{*}{$\begin{array}{l}\text { Are you aware of these } \\
\text { issues? }\end{array}$} & \multicolumn{2}{c}{ Lowland } & \multicolumn{2}{c}{ Coastal } & \multicolumn{2}{c}{ Upland } \\
\cline { 2 - 7 } & Yes (\%) & No (\%) & Yes (\%) & No (\%) & Yes (\%) & No (\%) \\
\hline Air pollution & 95.00 & 5.00 & 46.67 & 53.33 & 96.67 & 3.33 \\
Water pollution & 98.33 & 1.66 & 51.67 & 48.33 & 80.00 & 20.00 \\
Hazardous chemical & 96.67 & 3.33 & 50.00 & 50.00 & 76.67 & 23.33 \\
waste & 95.00 & 5.00 & 41.67 & 58.33 & 81.67 & 18.33 \\
Organic pollutants & 100.00 & 0.00 & 40.00 & 60.00 & 90.00 & 10.00 \\
Chemical fertilizers & 81.67 & 18.33 & 48.33 & 51.67 & 73.33 & 26.67 \\
Unsustainable fishing & 96.67 & 3.33 & 26.67 & 73.33 & 86.67 & 13.33 \\
Land degradation & 100.00 & 0.00 & 51.67 & 48.33 & 93.33 & 6.67 \\
Environmental & 100.00 & 0.00 & 55.00 & 45.00 & 96.67 & 3.33 \\
regulation compliance & & & & &
\end{tabular}

$\mathrm{N}=180$ (60 per type). Source: fieldwork.

There were several consistencies within each region in terms of respondents' awareness of a specific issue (Table 8.7). In the lowland and upland areas, every issue had the majority of respondents reporting to be aware of it, with the lowland area overall having the greater awareness of the two. Conversely, of the coastal area's respondents, the majority were aware of only three of the nine issues. In the lowland area, three environmental issues, chemical fertilizers, 
environmental regulation compliance, and harmful waste disposal, all accounted for 100\%, followed by water pollution (98.33\%), and hazardous chemical waste and land degradation (96.67\% each); while the lowest awareness was of unsustainable fishing (81.67\%), followed by air pollution and organic pollutants (95\% each). Similarly, our respondents in the upland area had the highest awareness of air pollution and harmful waste disposal (96.67\% each), followed by environmental regulation compliance (93.33\%) and chemical fertilizer (90.00\%); while the lowest awareness was of unsustainable fishing (73.33\%), followed by hazardous chemical waste (76.67\%), water pollution (80.00\%), and organic pollutants (81.67\%). Even in cases where the majority was aware of an issue, the percentages in the coastal area were much lower than those in the other two regions. The highest awareness was of harmful waste disposal (55.00\%), followed by water pollution and environmental regulation compliance ( $51.67 \%$ each), and hazardous chemical waste (50.00\%). Meanwhile the lowest awareness was of land degradation (26.67\%), followed by chemical fertilizers (40\%), organic pollutants (41.67\%), air pollution (46.67), and unsustainable fishing (48.33\%).

Another consistency was in unsustainable fishing being the issue of which the lowest percentage of people in the lowland and upland areas were aware. This may be expected, as these people were not reliant on fishing as an income source. However, both research sites had greater awareness of this issue than the people in the coastal area, for whom fishing was an integral part of life. Limited education, training, and capacity building, as well age of business, may have had an effect on the environmental awareness of the peoples of these areas. However, the disparity between the coastal area and the lowland and upland areas warrants greater attention from the government, NGOs, and MFIs. While factors such as poverty and few income alternatives may cause resource overexploitation, they do not account for lack of awareness. The exact reason for the coastal area's lower awareness on an issue that affects it the most requires further research.

We conducted quantitative interviews to see whether the presence of MFIs affected the clients' behavior and environmental awareness, and whether the MFIs' programs and policies made positive contributions to environmental preservation. In Table 8.8, answers to whether the MFIs provided training on environmental issues are presented. 
Table 8.8: Training on environmental issues provided by the MFIs.

\begin{tabular}{lrrr}
\hline \multirow{2}{*}{$\begin{array}{l}\text { Do MFIs provide training on } \\
\text { environmental issues? }\end{array}$} & \multicolumn{3}{c}{ Geographical area } \\
\cline { 2 - 4 } & Lowland (\%) & Coastal (\%) & Upland (\%) \\
\hline Yes & 16.67 & 11.67 & 11.67 \\
No & 70.00 & 38.33 & 33.33 \\
Don't know & 13.33 & 50.00 & 55.00 \\
\hline Total & 100.00 & 100.00 & 100.00 \\
\hline
\end{tabular}

$\mathrm{N}=180$ (60 per area). Source: fieldwork.

In all three regions, more respondents reported that they did not receive training from their MFI than those who did (Table 8.8). The lowland area had by far the highest percentage, with 70\%, followed by the coastal and upland areas, with 38.33\% and 33.33\%, respectively. Of those who reported receiving training, the lowland area had the highest percentage, with $16.67 \%$, followed by the coastal and upland areas, with $11.67 \%$ each. Although the majority in the lowland area belonged to the group who did not receive training, most of the respondents in the upland (55\%) and coastal (50\%) areas said that they did not know whether their MFI provided training. In the lowland area, this was the minority group with $13.33 \%$. These data indicate that the MFIs in all three areas had problems with providing environmental training to their clients, and that there was an additional lack of attention on the part of the clients. While it might be costly for the MFIs to dedicate a part of their net profit to environmental matters, one cost-effective way to improve environmental awareness amongst their clients may be to simply educate them of the existence of these training programs. In addition, the role of government as a policy- and decision-maker may prove helpful toward reaching the goals of environmental sustainability.

We also interviewed respondents as to whether they received social programs from their financial institution concerning environmental degradation (Table 8.9).

Table 8.9: Social programs provided by the MFIs.

\begin{tabular}{lrrr}
\hline Do MFIs provide some social & \multicolumn{3}{c}{ Geographical area } \\
\cline { 2 - 4 } programs? & Lowland (\%) & Coastal (\%) & Upland (\%) \\
\hline Yes & 18.33 & 15.00 & 13.33 \\
No & 73.33 & 40.00 & 31.67 \\
Don't know & 8.33 & 45.00 & 55.00 \\
\hline Total & 100.00 & 100.00 & 100.00 \\
\hline
\end{tabular}

$\mathrm{N}=180$ (60 per area). Source: fieldwork.

Similar to the environmental training percentages (Table 8.8), the majority of respondents in the lowland area (73.33\%) believed that their MFI did not provide social programs, while $40 \%$ in the 
coastal area and $31.67 \%$ in the upland area also reported the same. Once again, most of the respondents in the upland and coastal areas, 55\% and 45\%, respectively, and a small number in the lowland area, 8.33\%, reported that they did not know whether their MFI provided any social programs on environmental matters. Only a limited percentage of clients in the lowland (18.33\%), coastal (15\%), and upland (13.33\%) areas confirmed that the MFIs provide social programs. These data further indicate the low level of the MFIs' contributions to environmental awareness.

Table 8.10: Problems faced by the respondents.

\begin{tabular}{lrrr}
\hline Do you perceive any problems & \multicolumn{3}{c}{ Geographical area } \\
\cline { 2 - 4 } $\begin{array}{l}\text { in maintaining the } \\
\text { environment? }\end{array}$ & Lowland (\%) & Coastal (\%) & Upland (\%) \\
\hline Yes & 5.00 & 23.33 & 16.67 \\
No & 95.00 & 76.67 & 83.33 \\
\hline Total & 100.00 & 100.00 & 100.00 \\
\hline N = 180 (60 per area). Source: fieldwork. & &
\end{tabular}

Despite being the region with the lowest MFI environmental support, the lowland area had the highest percentage (95\%) of respondents reporting that they did not perceive any problems in maintaining the environment (Table 8.10). In the upland area, this group accounted for 83.33\%, while in the coastal area, it accounted for $76.67 \%$. All three regions were consistent in containing a majority of respondents who felt they were able to maintain the environment on their own, suggesting that the main perception amongst the people of these regions was that they could maintain the environment without any additional assistance. In general, based on our direct observations, the areas were polluted by large amounts of waste, some of which was deposited into their respective rivers. These polluted rivers would then be utilized for their daily activities. In addition to the small impact of MFIs on environmental awareness in the three areas, a basic lack of knowledge in environmental issues might also have been a factor in their low environmental awareness.

Overall, our data shows that the MFIs provided training and social programs on environmental issues on a very small scale, only. Some factors that may have played a role in the respondents' perception that there was little difficulty in maintaining the environment are the social cohesion of the people within the region, local culture, and religious teaching and norms. However, in our direct observations of the areas, we observed that, despite the perception of little difficulty, much environmental improvement, particularly to rivers and arable land, was required. 
By working together with both the local and central government, as well as NGOs, MFIs might make greater progress in increasing environmental awareness. Although environmental regulations exist, no governmental policies meant to increase environmental awareness have yet been created in any of the regions. The government may use the MFIs as a proxy by providing them with incentives to target clients with environmentally-friendly businesses.

\subsection{Comparative Analysis between Islamic and Conventional MFIs}

The establishment of MFIs is considered to have a positive contribution to poverty alleviation. Khandker (2005), in his research on the effect of microfinance on poverty reduction in Bangladesh, found that microfinance had a positive impact on poverty reduction by one percentage point per year. In addition, microfinance had a greater impact on extreme poverty than moderate poverty. The microfinance institution studied by Khandker was a conventional MFI. Mislan, Widiyanto, and Ghafar (2008), in analyzing the sustainability of Islamic microfinancing for developing micro-enterprises, found that Islamic microfinancing was useful for developing micro-enterprises, in addition to providing social benefits.

Based on field interviews and surveys with the respondents, MFI officials, and key informants, we compared Islamic and conventional microfinance institutions in terms of their effects on poverty alleviation and environmental awareness.

\subsubsection{RESPONDENT CHARACTERISTICS}

While there were no significant differences in characteristics between the clients of Islamic and conventional microfinance institutions, data on their characteristics are useful for providing supporting information that may assist with understanding not just whether there are client-based explanations for differences between the two institution types and how their roles in poverty alleviation and environmental awareness are affected, but whether individual characteristics have an effect on factors such as fund usage and financial scheme choice (Table. 8.11). 
Table 8.11: Heads of household characteristics.

\begin{tabular}{|c|c|c|}
\hline \multirow{2}{*}{ Household characteristics } & \multicolumn{2}{|c|}{ Types of MFI } \\
\hline & Islamic MFIs & Conventional MFIs \\
\hline \multicolumn{3}{|l|}{ Age: } \\
\hline Mean & 41.21 & 41.86 \\
\hline Minimum & 25 & 21 \\
\hline Maximum & 60 & 63 \\
\hline \multicolumn{3}{|l|}{ Religion (\%): } \\
\hline Islam & 100.00 & 100.00 \\
\hline \multicolumn{3}{|l|}{ Able to write (\%): } \\
\hline No & 2.22 & 0.00 \\
\hline Yes & 97.78 & 100.00 \\
\hline \multicolumn{3}{|l|}{ Educational level (\%): } \\
\hline Never attended school & 3.33 & 0.00 \\
\hline Some elementary school & 8.89 & 6.67 \\
\hline Completed elementary school & 32.22 & 38.89 \\
\hline Attended junior high school & 3.33 & 3.33 \\
\hline Completed junior high school & 18.89 & 17.78 \\
\hline Attended senior high school & 2.22 & 1.11 \\
\hline Completed senior high school & 18.89 & 25.56 \\
\hline Attended academy/university & 12.22 & 6.67 \\
\hline \multicolumn{3}{|l|}{ Informal Education (\%): } \\
\hline No & 68.89 & 63.33 \\
\hline Yes & 31.11 & 36.67 \\
\hline \multicolumn{3}{|l|}{ Main occupation (\%): } \\
\hline Self-employed in agriculture & 42.22 & 45.56 \\
\hline Self-employed in off-farm enterprises & 46.67 & 27.78 \\
\hline Government employee & 2.22 & 4.44 \\
\hline Casual worker & 1.11 & 10.00 \\
\hline Salaried worker in non-agriculture & 7.78 & 12.22 \\
\hline \multicolumn{3}{|l|}{ Family size: } \\
\hline Mean & 3.99 & 3.68 \\
\hline Minimum & 2 & 2 \\
\hline Maximum & 7 & 6 \\
\hline
\end{tabular}

$\mathrm{N}=180$ (90 per type). Source: fieldwork.

There were very small differences between the clients of the Islamic MFIs and the clients of the conventional MFIs (Table 8.11). For example, 100\% of the clients amongst both types were Muslim, while the mean client age varied by only 0.65 (41.21 to 41.86), the mean literacy rate by $2.22 \%(97.78 \%$ to $100 \%$ ), and the mean family size by 0.31 (3.99 to 3.68). The greatest differences were restricted to education and occupation. The conventional MFI group had a higher percentage of clients who completed elementary school, $38.9 \%$ to $32.2 \%$, and clients who 
completed senior high school, $25.56 \%$ to $18.89 \%$, while the Islamic MFI group had a greater percentage of clients who attended an academy/university, $12.22 \%$ to $6.67 \%$. Counterintuitively, the Islamic MFI group had the lower percentage of clients with informal educations, $31.11 \%$ compared with $36.67 \%$ of the conventional MFIs' clients. Informal education includes religious education, and entrepreneurial and managerial training. The majority of clients in both groups were self-employed, but while the conventional MFI group had a higher percentage of clients self-employed in agriculture, $45.56 \%$ to $42.22 \%$, the Islamic MFI group had the higher percentage of clients self-employed in off-farm enterprises, $46.67 \%$ to $27.78 \%$. Additionally, more clients of the conventional MFIs had salaried occupations outside of the agricultural sector than those of the Islamic MFIs, $12.22 \%$ to $7.78 \%$. These few differences between the two groups suggest that, overall, personal factors, such as age, religion, education, and occupation, had no or little effect on MFI type selection amongst the people of our research areas.

\subsubsection{Clients' Preferences: SAVIngs Versus LoAN SERVices}

Although they also provided other services, loans and savings accounts were the core offerings of the MFIs in our research areas. These two services did not differ from those provided by microfinance institutions in other regions. Clients usually went to the MFIs to save their surplus income from their businesses, or to apply for initial or additional capital. In the case of the coastal, lowland, and upland areas, the Islamic MFIs required their clients to open a savings account when applying for financing. Based on their experiences with their institutions, respondents were interviewed on whether they preferred to join Islamic MFIs (IsMFIs) or conventional MFIs in terms of their saving and loan services (Figure 8.2).

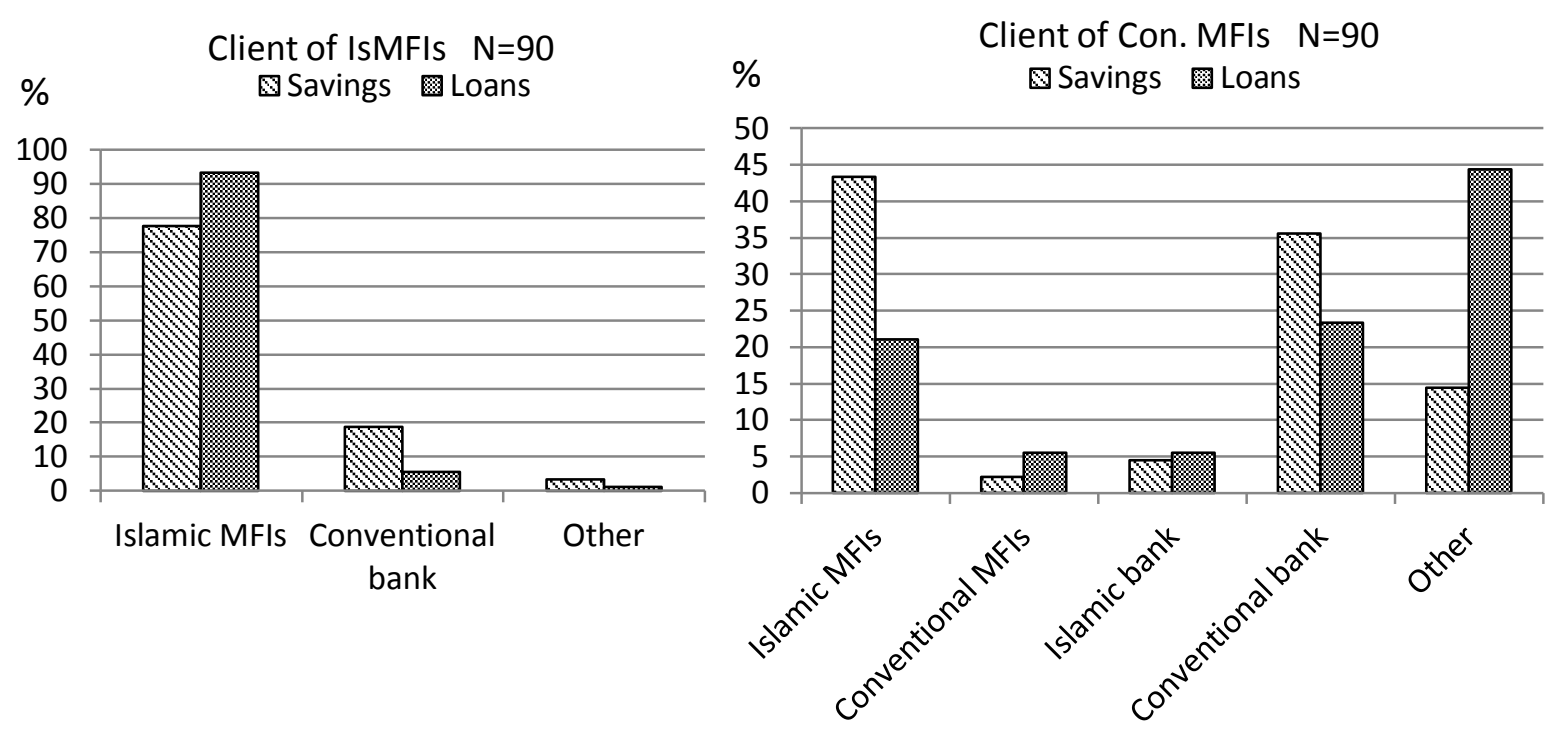

Figure 8.1: Clients’ preferences regarding savings and financing/loan services. 
Figure 8.1 shows that most Islamic MFI clients would prefer to apply for a savings scheme from an Islamic MFI (77.78\%), while a smaller percentage (18.89\%) would prefer to do so with a conventional bank. Only 3.33\% said they would prefer that of other financial institutions. Similarly, $43.33 \%$ of the conventional MFI clients stated they would prefer to apply for a savings scheme from an Islamic MFI, followed by one from a conventional bank (35.56\%). More clients (14.44\%) reported that they would prefer other forms of saving their money-such as keeping their money in their homes or with their relatives, or in their children's savings accounts with their schools-or Islamic bank (4.44\%) to a conventional MFI (2.22\%). Both clients of the Islamic MFIs and the conventional MFIs showed a preference for the savings schemes of Islamic MFIs. Factors such as the Islamic MFIs' compliance with Islamic laws (in communities that were predominantly Muslim) and the use of profit-sharing as opposed to the interest-based schemes of the conventional MFIs were large contributors to this discrepancy.

Figure 8.1 also shows that a significant percentage (93.33\%) of the Islamic MFI clients would prefer to apply for the financing/loan services provided by Islamic MFIs, whereas only 5.6\% would prefer those of conventional MFIs. Surprisingly, $44.44 \%$ of the conventional MFIs' clients would be interested in applying for a loan from other sources, such as their relatives or moneylenders, while 23.33\% would prefer a conventional bank, and $21.11 \%$ an Islamic MFI. Just $5.56 \%$ of the conventional MFIs' clients would prefer to apply for a loan from a conventional MFI. The contrast of the significant majority of the Islamic MFI clients, and 21.11\% of conventional MFI clients, all stating a preference for acquiring financing from an Islamic MFI, and only a very small minority from both types stating a preference for acquiring loans from a conventional MFI suggests that clients of not just Islamic MFIs, but conventional MFIs, as well, trusted the Islamic MFIs more than the conventional MFIs when it came to financing or loans. That so few clients of the conventional MFIs would prefer to apply for a loan from another conventional MFI may be a reflection of the conventional MFIs' more difficult and lengthy loan application process compared with the alternatives. One reason for the greater trust in Islamic microfinance may also be the qard al hasan schemes, which are credit schemes without the interest found in conventional banking.

\subsubsection{ASYMMETRIC INFORMATION}

MFIs generally use a monitoring strategy to ensure their credit schemes are effective and that clients use their loans appropriately. Enhancing capacity building and adopting group-based lending mechanisms may affect the transfer of information between institution and client, and thus minimize adverse selection and moral hazards (Dusuki 2008). In our study, asymmetric 
information frequently occurred when the clients did not fulfill their agreements with their institutions, and promises that were made when they signed their financial contracts. Some of the clients of the MFIs used their financing/loans for purposes other than those specified in their applications. Others would apply for financings/loans on behalf of other people, abusing the trust of the institutions. A further number used the funds acquired by their spouses for their own, personal needs, creating a moral hazard.

\subsubsection{Financing/loan Usage Contrary to What the Clients Applied for}

Clients of both Islamic and conventional MFIs, as well as key informants, were interviewed as to the usage of their acquired funds. This information is meaningful to understand the asymmetric information problem that occurs between institutions and their clients. Based on our research design and discussions with the directors of some MFIs, we decided to interview clients of MFIs who received financing/loans for productive economic activities. Their usage was categorized as non-productive, income creation, and business development. Non-productive economic activities include things such as consumption, house renovations, paying tuition fees, and buying motorcycles.

Table 8.12: Usage of clients’ financing/loans.

\begin{tabular}{lrr}
\hline Financing/loan Usage & Islamic MFIs (\%) & Conventional MFIs (\%) \\
\hline Non-productive & 11.11 & 22.22 \\
Income creation & 31.11 & 32.22 \\
Business development & 57.78 & 45.56 \\
\hline Total & 100.00 & 100.00 \\
\hline
\end{tabular}

$\mathrm{N}=180$ (90 per type). Source: fieldwork.

Of the three categories, clients who used their financing/loans for non-productive activities accounted for the lowest percentages in both MFI types. However, while they accounted for $11.11 \%$ of the Islamic MFI group, 22.2\% of the respondents in the conventional MFI group reported using their funds for non-productive activities. These percentages indicate a moral hazard case, when the use of these funds affected their ability to repay their loans. Less strict usage rules from the conventional MFIs might be the cause of the higher percentage of clients compared with the Islamic MFIs, who required their financing to be used for productive purposes.

Generally, our respondents derived their incomes based on small-medium enterprises exploiting agricultural, marine, or agroforestry resources. During certain seasons they required capital injection from financial institutions to drive their economic activities. Hence, appropriate fund 
usage is believed to affect the welfare levels of families, since loan applications are aimed at business development, adding business capital as well as balancing their income and expenditure. Using loans for non-productive activities as opposed to business development had a negative impact on welfare.

\section{Box 8.1: Financing/loan Usage from Islamic and conventional MFI Clients}

We conducted in-depth interviews with microfinance experts regarding the fund usage of the clients of both Islamic and conventional MFIs. This information was useful to further understand the different manners in which the MFI clients would use their funds.

The first microfinance expert we interviewed was Marhaban, an auditor of Islamic and conventional financial institutions. He assumed that Islamic MFIs still had "grey transactions", unclear financial schemes. According to him, profit sharing at a ratio of 40:60 was still unfair since clients had poor accounting practices in their businesses. Hence, cheating in these transactions was possible. Concerning fund usage differences between Islamic and conventional MFI clients, he said, "Almost $100 \%$ of conventional MFIs' clients used their loans for productive activities, including raising cattle, purchasing fodder, and farming, while $100 \%$ of the clients of Islamic MFIs used their financing for productive activities. And generally, the Islamic MFIs conducted field surveys on their clients' businesses before giving them financing."

The second expert was H. Munawar Ilham, a head of the Cooperative Department of Pasuruan District. Regarding the differences in fund usage, he said, "The loan usage of the conventional MFIs' clients was $50 \%$ for productive economic activities and $50 \%$ for consumption. The Islamic MFIs' clients had a greater percentage (80\%) using their financing for productive activities compared with those of the conventional MFIs, with only $20 \%$ of the financing being used for non-productive activities."

Abdul Majid Umar, the third microfinance expert, was a member of the Indonesian Association of Islamic Microfinance/BMT (ABSINDO). On the differences in fund usage between Islamic and conventional MFI clients, he said, "Around $60 \%$ of the clients of conventional MFIs usually used their loans for their business development, and $40 \%$ for consumption. Meanwhile, Islamic MFI clients used around $90 \%$ of their financing/loans for deriving their incomes rather than nonproductive economic activities."

To cover all their costs, the Islamic microfinance institutions provided a number of financing schemes with differing characteristics. The MFIs' clients were asked to specify which schemes they had adopted with their particular institution. Our initial questionnaire comprised four schemes: shirkah musharaka (the institution and its clients providing funds to other clients together), shirkah mudharabah mutlaqah (the institution alone providing funds), shirkah mudharabah (similar to shirkah mudharabah mutlaqah, but less strict), and qard al hasan. 
During our interviews, however, other schemes were introduced. These were ba'i bi tsaman 'ajil (providing goods in the place of funds), wadi'ah (temporarily giving ownership of their possessions to the institution), and nadzar (promising to repay a certain percentage, in addition to the full amount).

Table 8.13: Financing schemes adopted by the Islamic MFIs’ clients.

\begin{tabular}{lr}
\hline Financing scheme & Percent \\
\hline Shirkah musharaka & 2.22 \\
Shirkah mudharabah mutlaqah & 10.00 \\
Shirkah mudharabah & 4.44 \\
Qard al hasan & 17.76 \\
Others: & \\
Ba'i bi tsaman 'ajil & 44.44 \\
Wadi'ah & 17.76 \\
Nadzar & 2.24 \\
Other & 1.11 \\
\hline Total & 100.00 \\
\hline N = 90. Source: fieldwork.
\end{tabular}

The most adopted scheme was ba'i bi tsaman 'ajil, with 44.44\% (Table 8.13). This scheme involves Islamic MFIs transferring goods instead of funds to their clients. As a financing scheme, ba'i bi tsaman 'ajil is not in accord with Islamic law; it is, instead, considered an instrument of sale, not financing. Paradoxically, however, the Islamic MFIs in our research areas who provided this scheme supplied money to their clients, not goods. While this meant there was less of a breach of Islamic law, more practical problems were presented. Funds instead of goods had the risk of moral hazards, that their clients would use the funds for purposes contrary to what the Islamic MFIs intend, and which may affect them should problems with repayment occur.

The two second-most adopted schemes were qard al hasan and wadi'ah, with $17.76 \%$ each. The former indicates some awareness of the poverty_and thus difficulty to make repayments — of the people in these regions. Meanwhile, shirkah musharaka (2.22\%), shirkah mudharabah mutlaqah (10\%), and shirkah mudharabah (4.44\%) schemes were all adopted in low numbers.

Theoretically, shirkah and mudharabah (partnership schemes) are the core of Islamic finance. Our study, however, suggested otherwise. The high operational costs associated with these schemes, relating to the monitoring of their clients, might be the cause of these low percentages. On the clients' side, compared with the other schemes, the benefits of profit and loss sharing, at various ratios (such as 70:30, 60:40, or 50:50), were low enough for clients to perceive that the 
Islamic MFIs were the ones benefiting, not them, particularly when their institution would have a small or no role in running their business, but a large percentage of the profit. However, both the Islamic MFIs and their clients had limited knowledge of the concept of profit and loss sharing, and thus adoption of it was limited. In a case in Sudan, lack of knowledge on the part of financial officers on selection, evaluation, and profit management was the cause of the failure of a profit and loss sharing scheme (Ahmed 2008). In one of our focus group discussions with some of the MFIs' officials regarding profit and loss sharing, we were told:

It was difficult to implement a profit and loss sharing scheme because most of our clients had poor accounting. On the other side, we had a limited number of account officers to monitor the clients' businesses as well as their financial managements.

\subsubsection{Financing/loans Obtained on Behalf of Others}

Koperasi Wanita (cooperative for the female community), a conventional MFI, was welldeveloped in every village in our research area. Principally, Koperasi Wanita was meant to allow women to contribute to the incomes of their families, through avenues such as raising poultry, growing vegetables in their back yards, or engaging in petty trading. However, because of the roles of males as the decision-makers of their families, we found that women were not as empowered as MFIs intended, when they did not have control over the usage of their acquired funds.

In our three research areas, clients of the Islamic MFIs would obtain financing on behalf of a colleague or family member. The Islamic MFIs usually visited the houses of applicants to know their economic or business feasibility before approving any financing. Sometimes, applicants asked longtime clients for assistance with applying for financing, whether it be vouching for them or, more commonly, applying on their behalf. Islamic MFIs were open to approving financing for longtime clients, with whom they were already familiar, and whom they perceived to be good clients.

\subsubsection{Lack of Information on Potential Clients' Business Acumen}

Generally, the clients of the MFIs had limited knowledge and skill when it came to their occupations. Regardless, the MFIs would decide to give credit without having enough information with regards to the risk level of clients' businesses. Compared with their skilled counterparts, unskilled clients had higher risks of defaulting. Consequently, those unskilled clients would have difficulties repaying their credit installments. A common response amongst 
the MFIs would then be to reschedule the installment periods for these clients, both as a courtesy to the client and a way to publically maintain performance by reducing the occurrence of nonperforming loans. While the perception of high performance was of benefit to the MFIs, rescheduling, along with a lack of information, created the risk of adverse selection amongst their clients. According to Ahmed (2002), simply ensuring that knowledge of potential clients' business acumen is ample and correct before approving their loans can diminish the risk of adverse selection.

\subsubsection{The EFFects of Islamic ANd Conventional MFIs on Poverty AlleViation}

We analysed the comparative effects of Islamic and conventional MFIs on poverty alleviation as indicated by their clients' welfare changes after receiving financing/loans. The different uses of funds (non-productive, income creation, and business development) impacted the performance of their business and, consequently, their profits. Business performance and profits then affected welfare, which is reflected in consumption, health care, education and information, and empowerment.

\subsubsection{Business Performance}

The goal of microfinance is to enhance livelihoods, whether through providing start-up capital or assisting with balancing income and expenditures. Thus, microfinance institutions had an effect on the businesses of their clients (Table 8.14)

Table 8.14: MFIs' effects on clients’ business

\begin{tabular}{lrr}
\hline Do MFIs' financing/loans positively affect & Islamic MFIs & $\begin{array}{r}\text { Conventional } \\
\text { your business? }\end{array}$ \\
\hline Yes & 95.56 & MFIs (\%) \\
No & 4.44 & 67.76 \\
\hline Total & 100.00 & 32.22 \\
\hline $\mathrm{N}=180$ (90 per type). Source: fieldwork. & &
\end{tabular}

Although both types of microfinance institution had a positive effect on the businesses of their clients, amongst our respondents, the Islamic MFIs had a more positive effect than the conventional MFIs, $95.56 \%$ to $67.76 \%$ (Table 8.14). Conversely, just 4.44\% reported that their Islamic MFI had no effect on their business compared with the $32.22 \%$ who reported that their conventional MFI had no effect. This disparity between the two types indicates a greater influence on the part of the Islamic MFIs, and possibly greater benefits provided to their clients compared with the conventional MFIs. We believe that the screening system used by the Islamic 
MFIs, in particular their targeting of clients who were less inclined to use their funds for unrelated uses, had a significant effect on the development of their clients' businesses.

The clients who reported their MFI having a positive effect on the development of their business were then asked whether that development had an impact on the welfare of their family (Table 8.15).

Table 8.15: Effect of business development on family welfare.

\begin{tabular}{lrr}
\hline $\begin{array}{l}\text { Does the development of your business } \\
\text { impact your family's welfare? }\end{array}$ & $\begin{array}{r}\text { Islamic } \\
\text { MFIs }\end{array}$ & $\begin{array}{r}\text { Conventional } \\
\text { MFIs (\%) }\end{array}$ \\
\hline Yes & 100.00 & 87.21 \\
No & 0.00 & 12.79 \\
\hline Total & 100.00 & 100.00 \\
\hline $\mathrm{N}=147$ (86 with Islamic MFIs, 61 with conventional MFIs). Source: \\
fieldwork.
\end{tabular}

Similar to Table 8.14, Table 8.15 shows that the majority of the respondents felt that the development of their business had an impact on their family's welfare. All of the clients of the Islamic MFIs (100\%) reported in the affirmative, while this was the case with $87.21 \%$ of those belonging to conventional MFIs. It is likely, therefore, that in our three research sites microfinance had a significant impact on family welfare, Islamic microfinance more so than conventional microfinance.

We interviewed a number of village leaders, microfinance experts, politicians, and Islamic MFI officials to understand their perception of Islamic microfinance's role in reducing poverty (Table 8.16).

Table 8.16: Effect of Islamic microfinance on poverty alleviation.

\begin{tabular}{lrr}
\hline $\begin{array}{l}\text { Does Islamic microfinance alleviate } \\
\text { the poverty of clients? }\end{array}$ & No. of expert respondents & Percent \\
\hline Yes & 20 & 90.91 \\
No & 1 & 4.55 \\
Don't know & 1 & 4.55 \\
\hline Total & 22 & 100.00 \\
\hline
\end{tabular}

$\mathrm{N}=22$. Source: fieldwork.

All but two of our expert respondents (90.91\%) agreed that Islamic microfinance helped reduce the poverty level of clients (Table 8.16). Only one respondent (4.55\%) said that Islamic microfinance did not affect poverty alleviation, while another (4.55\%) did not know. These 
percentages support the conclusions of Widiyanto, Mutamimah, and Hendar (2011) and Smolo and Ghafar (2011), who conducted studies in central Java and Malaysia, respectively, and found that Islamic MFIs were effective in empowering the needy, while still having the potential to do more.

Despite the high percentage of expert respondents reporting that Islamic microfinance affects poverty alleviation, they differed on what the best strategies to combat poverty were with regards to these microfinance institutions (Table 8.17).

Table 8.17: Best strategies to reduce poverty.

\begin{tabular}{lrr}
\hline Strategy & No. of expert respondents & Percent \\
\hline $\begin{array}{l}\text { Islamic MFIs can provide more financing to } \\
\text { their clients. }\end{array}$ & 2 & 9.09 \\
$\begin{array}{l}\text { MFIs should continue to monitor and provide } \\
\text { solutions for their clients, and give training } \\
\text { and capacity building. }\end{array}$ & 3 & 13.64 \\
$\begin{array}{l}\text { MFIs should provide fair financing schemes } \\
\text { and abolish collateral. }\end{array}$ & 5 & 22.73 \\
$\begin{array}{l}\text { Corporate Social Responsibility (CSR) funds } \\
\text { should be distributed as far as remote areas } \\
\text { and reach all clients. }\end{array}$ & 1 & 4.55 \\
$\begin{array}{l}\text { The financial services should be directed to } \\
\text { wider communities and collaborate with all } \\
\text { related financial agencies. }\end{array}$ & 7 & 31.82 \\
No opinion. & 4 & 18.18 \\
\hline Total & 22 & 100.00 \\
\hline
\end{tabular}

$\mathrm{N}=22$. Source: respondent interviews.

Seven (31.82\%) of our expert respondents recommended that Islamic MFIs provide their financial services to wider range of communities and collaborate with all related financial agencies. This percentage suggests that the Islamic MFIs — or at least some of them-did not provide their services to enough people within each region, limiting their outreach. Many of the Islamic MFIs showed a clear preference for graduates of pondok pesantren. The Islamic MFIs also had limited collaboration with other financial agencies (including cooperative offices). Five respondents (22.73\%) said that the Islamic MFIs should provide fair financing schemes and abolish collateral. Since the profit-sharing system was problematic for both sides-the institutions and their clients-the Islamic MFIs' clients were required to provide collateral upon 
being approved for financing. Dumairi Noer (pers. comm.), a manager of an Islamic MFI in the lowland area of Kraton Subdistrict, said:

We had difficulties with the profit-sharing scheme because our clients' businesses had poor accounting. There was also the risk of moral hazards because we gave them the freedom to use their funds however they pleased. Thus, our clients asked our institution to provide a safe and simple scheme that accounted for these factors.

Our respondents informed us of on what their business profits were spent (Table 8.18).

Table 8.18: Distribution of business profits

\begin{tabular}{lrr}
\hline Item distribution & Islamic MFIs (\%) & Conventional MFIs (\%) \\
\hline House renovation & 15.12 & 20.75 \\
Increased household goods & 15.12 & 9.43 \\
Increased employees & 3.49 & 1.89 \\
Increased business size & 62.79 & 66.04 \\
Other & 3.49 & 1.89 \\
\hline Total & 100.00 & 100.00 \\
\hline
\end{tabular}

$\mathrm{N}=139$ (86 with Islamic MFIs, 53 with conventional MFIs). Source: fieldwork.

The majority of respondents from both the Islamic and conventional MFIs spent their profits on increasing the size of their business (Table 8.17). A smaller number but higher percentage were the clients of the conventional MFIs, with 66.04\% (35 people), while 62.79\% (54 people) were Islamic MFI clients. This preference was followed by renovating their house, 20.75\% (11 people) of them conventional MFI clients and 15.12\% (13 people) Islamic MFI clients, and purchasing household goods. The number of Islamic MFI clients was the same as those who spent their profits on house renovation: $15.12 \%$ (13 people). Meanwhile, contrasting the higher percentage of people spending their profits on increasing the size of their business and renovating their house compared with the clients of the Islamic MFIs, the percentage of conventional MFI clients spending their profits on household goods was smaller than that of the Islamic MFIs, with just 9.43\% (five people). These data indicate that the clients of both the Islamic MFIs and the conventional MFIs preferred to allocate their profit to developing their business, with a slightly higher percentage of them coming from conventional MFIs. 


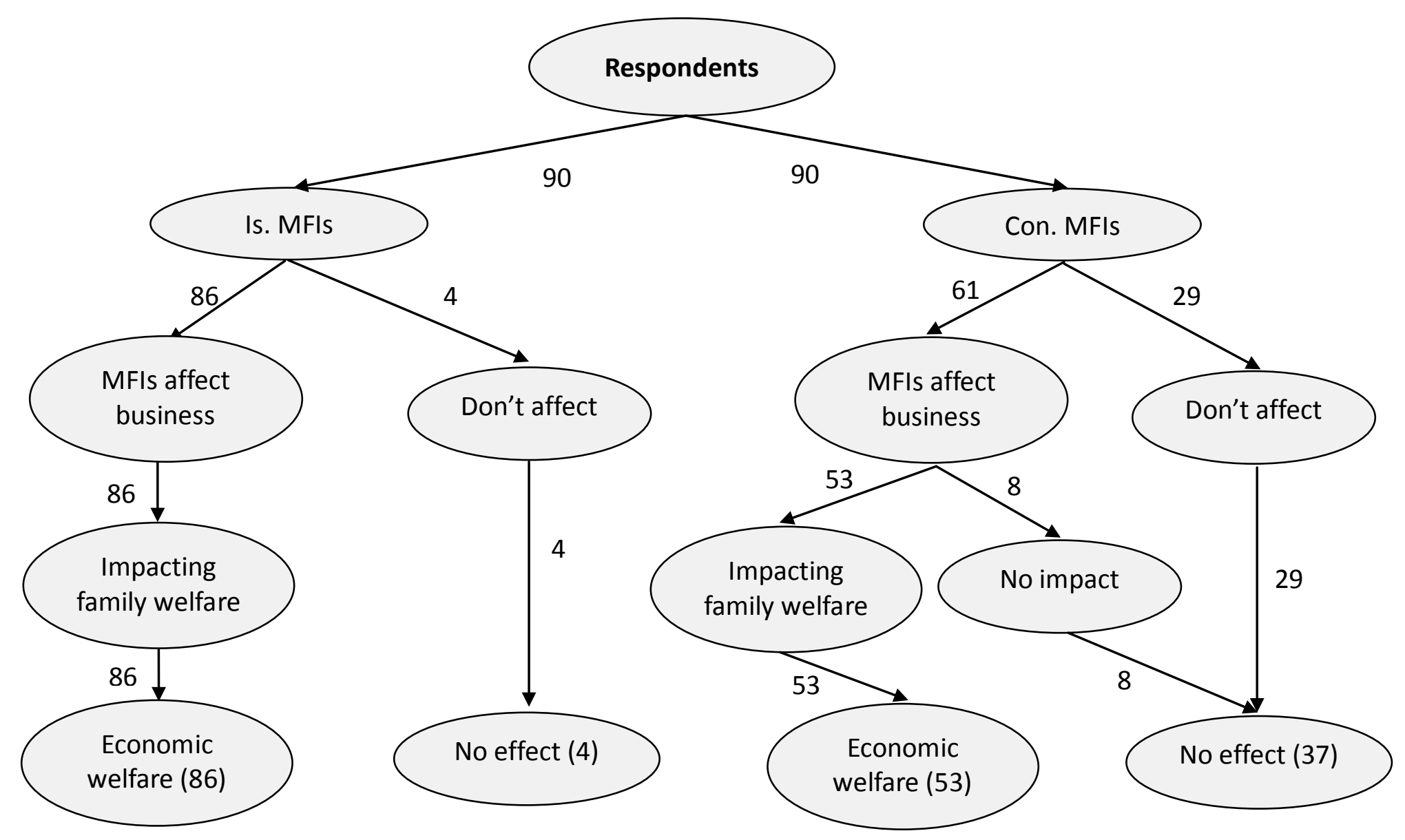

Figure 8.2: Flowchart of the effects of the MFIs' financing/loans on poverty alleviation. 
Eighty-six (95.56\%) clients of the Islamic MFIs had better economic welfare after receiving financing from their institution, while 53 (58.89\%) clients of the conventional MFIs had better economic welfare (Figure 8.3). These data suggest that the Islamic MFIs had a more positive effect on poverty alleviation (economic welfare) than the conventional MFIs. That 37 (41.11\%) clients of the conventional MFIs saw no welfare improvement after joining suggests that these MFIs' policies on poverty alleviation have either been ineffective or require more time or effort from their officials before having any significant impact on their clients’ welfare.

\subsubsection{Welfare Indicators}

Microfinance is considered to have a positive effect on clients' welfare. The financial schemes of the MFIs were generally used by their clients to improve their welfare through various economic activities.

Table 8.19: Consumption of respondents after receiving financing/loans.

\begin{tabular}{lrr}
\hline Consumption & Islamic MFIs (\%) & Conventional MFIs (\%) \\
\hline Improved & 93.33 & 75.56 \\
Unchanged & 6.67 & 23.33 \\
Deteriorated & 0.00 & 1.11 \\
\hline Total & 100.00 & 100.00 \\
\hline $\mathrm{N}=180$ (90 per type). Source: fieldwork. & &
\end{tabular}

With 93.33\% and 75.56\%, respectively, the Islamic and conventional MFIs both improved the consumption of our respondents (Table 8.19). The Islamic MFIs improved the consumption of a greater number of clients compared with the conventional MFIs, and, accordingly, the conventional institutions had more respondents reporting that their consumptions were unchanged, $23.33 \%$ to $6.67 \%$. These data indicate that microfinance contributed to improved consumption, with Islamic MFIs having a greater than conventional MFIs.

We interviewed the respondents on their profit allocation, asking how they prioritized the spending of their business's profits (Figure 8.3). The clients of both Islamic and conventional MFIs preferred to use their profits for purchasing food, although they also used it for saving money and purchasing clothing. 


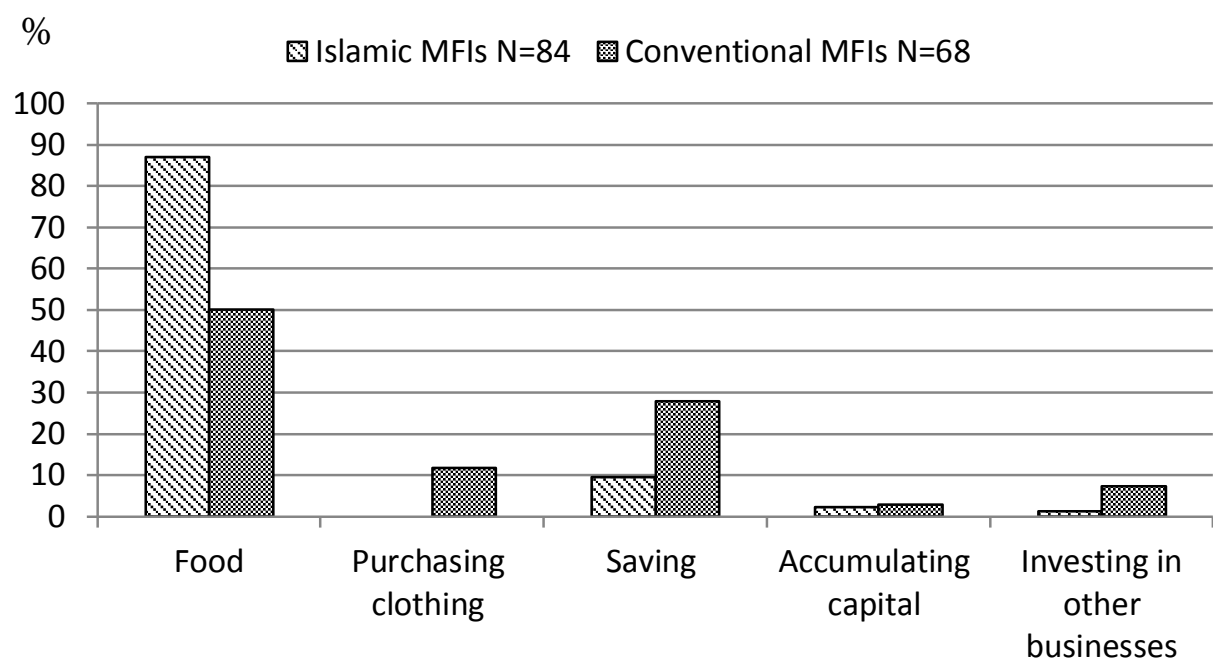

Figure 8.3: Allocation of profit amongst Islamic and conventional MFI clients.

Examples of poor health care in the three research sites includes inhabitants' inabilities to afford adequate treatment and medication, and low hygiene awareness as evidenced by trash and signs of defecation found in and near water sources. Thus, improved health care in these regions was indicated by the abilities of clients to keep themselves and their families free of disease, to purchase medicine, and maintaining good environmental hygiene. Respondents were asked whether their health care improved after joining their microfinance institution (Table 8.20).

Table 8.20: Health care improvement amongst clients of MFIs.

\begin{tabular}{lrr}
\hline Health care & Islamic MFIs (\%) & Conventional MFIs (\%) \\
\hline Improved & 92.22 & 75.56 \\
Unchanged & 7.78 & 23.33 \\
Deteriorated & 0.00 & 1.11 \\
\hline Total & 100.00 & 100.00 \\
\hline
\end{tabular}

$\mathrm{N}=180$ (90 per type). Source: fieldwork.

Respondents of both institution types reported an improvement in health care, with the Islamic MFI group have a higher percentage than the conventional MFI group, 92.22\% to $75.56 \%$ (Table 8.20). Consequently, the conventional MFI group had more respondents reporting that their health care remained unchanged after joining their institution, $23.33 \%$ to $7.78 \%$. While health care was affected largely regardless of institution type, our data suggests that clients who applied with an Islamic MFI were more likely to see health care benefits.

Respondents were instructed to prioritize a number of health care indicators in terms of importance to them (Figure 8.4). A significant majority of Islamic MFI clients prioritized going 
to the doctor (87.95\%) over purchasing basic medication or first aid kits (7.23\%), and maintaining environmental hygiene (4.82\%). This was the same case with those of conventional MFIs, but in slightly more proportionate numbers; $60.29 \%$ preferred to go the doctor, whereas 20.59\% preferred to purchase basic medication or first aid kits, and 19.12 to maintain environmental hygiene.

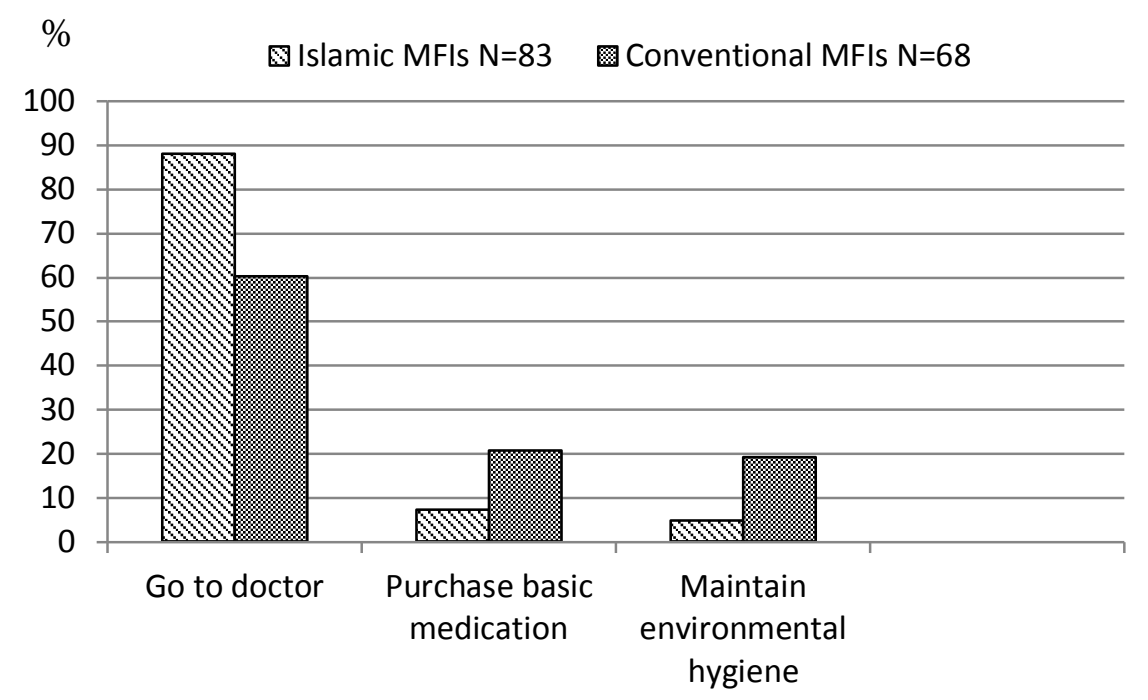

Figure 8.4: Clients’ prioritization of health care.

Respondents were asked whether their education and information access was affected by their MFI (Table 8.21).

Table 8.21: Education and information access.

\begin{tabular}{lrr}
\hline Education and information access & Islamic MFIs (\%) & Conventional MFIs (\%) \\
\hline Improved & 91.11 & 75.56 \\
Unchanged & 8.89 & 23.33 \\
Deteriorated & 0.00 & 1.11 \\
\hline Total & 100.00 & 100.00 \\
\hline
\end{tabular}

$\mathrm{N}=180$ (90 per type). Source: fieldwork.

Table 8.21 shows that a larger percentage of the Islamic MFIs' clients (91.13\%) saw an improvement in their education and information access compared with the conventional MFIs' clients (75.53\%). Similar to the results of previous tables in this chapter (8.19 and 8.20), 23.33\% of the clients of the conventional MFIs reported no improvement, compared with just $8.89 \%$ of the Islamic MFI clients.

There are several indicators of improved education and access to information, such as improved literacy, improved business performance, and students completing junior high school or pursuing higher education (Figure 8.5). Most Islamic MFI clients (51.22\%) prioritized having information 
access for their business over improved literacy (30.49\%), and having a family member pursue higher education (10.98\%) or completing junior high school (7.32\%). Conversely, most conventional MFI clients preferred to improve their own literacy first (38.24\%). This was followed by having a family member pursue higher education (29.41\%) or complete junior high school (19.12\%), and having greater access to information for their business (13.24\%).

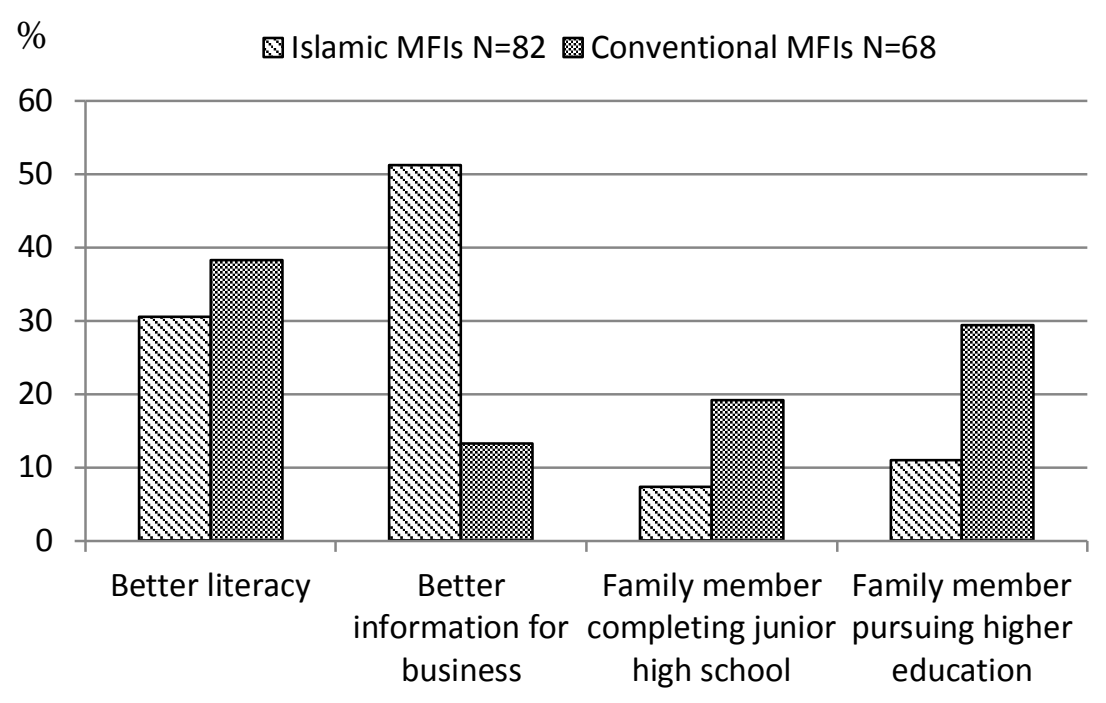

Figure 8.5: Indicators of better education and information access amongst MFI clients.

Empowerment is one of the poverty alleviation goals of the government and related nongovernmental organisations. Respondents were asked whether the MFIs' financing/loans had an impact on the empowerment of their clients (Table 8.22).

Table 8.22: Changes to client empowerment.

\begin{tabular}{lrr}
\hline Empowerment & Islamic MFIs (\%) & Conventional MFIs (\%) \\
\hline Improved & 85.56 & 67.78 \\
Unchanged & 14.44 & 30.00 \\
Deteriorated & 0.00 & 2.22 \\
\hline Total & 100.00 & 100.00 \\
\hline
\end{tabular}

$\mathrm{N}=180$ (90 per type). Source: fieldwork.

Of the clients of Islamic MFIs, 85.56\% reported an improvement to empowerment, while 14.44\% reported no change (Table 8.2). Similarly, though to a lesser extent, $67.78 \%$ of the conventional MFIs' clients reported an improvement, while 30\% said empowerment was unchanged. The higher number of assistance programs and training, along with the willingness to involve their officials in clients' personal matters, is the likely reason for the Islamic MFIs' greater success compared with the conventional MFIs. 
Empowerment indicators include improved social cohesion and job opportunities, along with greater freedom to express one's opinion or do what one wants (Figure 8.6). Amongst our respondents, better social relationships were the heavily preferred outcome of their empowerment, with the Islamic MFI group having a higher percentage than the conventional MFI group, $83.12 \%$ to $49.18 \%$. Of the Islamic MFI clients, $5.19 \%$ each preferred the ability to express their opinion or do what they want, while 3.90\% preferred greater involvement in society and $2.60 \%$ better job opportunities. Meanwhile, $16.39 \%$ of the conventional MFI clients preferred greater involvement in society, followed by $14.75 \%$ who preferred the freedom to do what they want, $13.12 \%$ better job opportunities, and $6.56 \%$ the freedom to express their opinion.

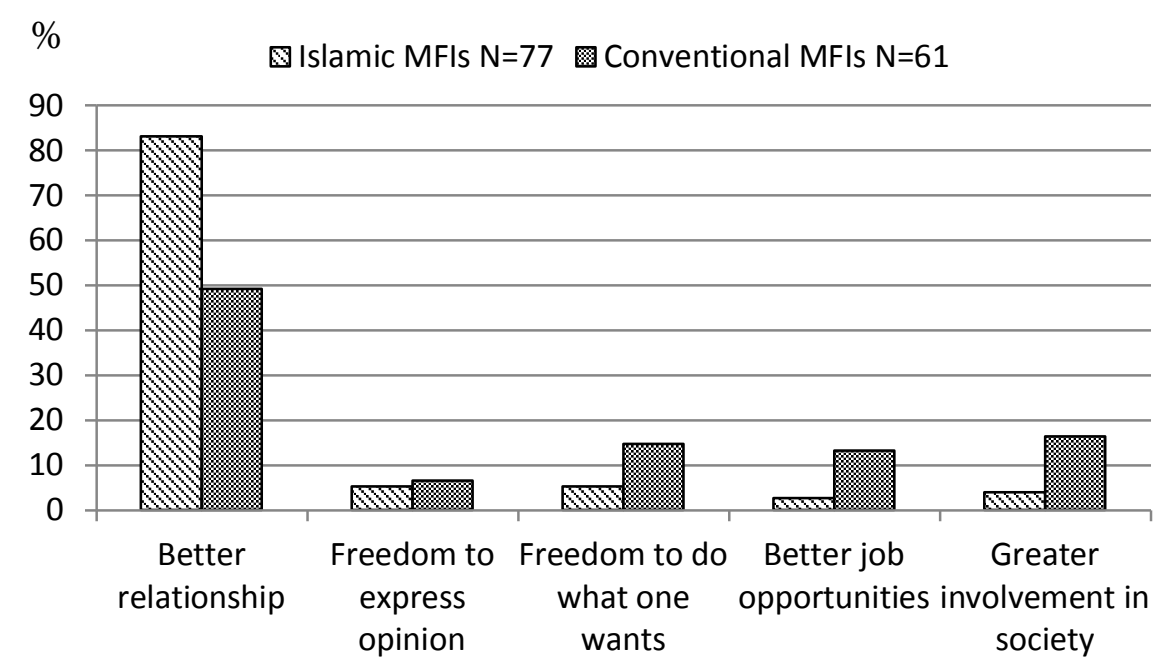

Figure 8.6: Preferred empowerment outcomes amongst MFI clients.

In general, our data shows that Islamic MFIs have a greater impact on poverty alleviation than conventional MFIs. The Islamic MFIs, with their range of interest-free financing options such as ijarah, murabahah, istisna, mudarabah, bai bi tsaman 'ajil, and qard al hasan, also had more flexible repayment plans compared with those of the conventional MFIs, being willing to reschedule an installment when a client failed a repayment. Qard al hasan, in particular, positively affected the welfare level of the very poor. Through this scheme, they saw better economic opportunities, and, consequently, better welfare. Furthermore, the Islamic MFIs managed charities, accepting donations through social practices such as zakat, infak, and shadaqah, which supported the MFIs' roles in poverty alleviation. Islamic MFIs usually then distributed these donations toward home renovations for the very poor, aid during natural disasters, and soft loans such as qard al hasan. On the other hand, conventional MFIs in our research areas usually based their financial services on interest. Presumably, they did not have a stake in the success of a client's business, since they had to repay their loan, regardless. 
Although the conventional MFIs' goals were also to empower the poor, they had too limited a number of schemes and sources of funds to significantly impact poverty alleviation.

Our findings are also in line with those of the United Nations Development Programme (2012) study on scaling up Islamic microfinance in Bangladesh through the private sector, which stated that Islamic MFIs made positive contributions to poverty alleviation, although these contributions were still not as great as they otherwise could have been, as the institutions failed to make full use of their financial capabilities. Marhaban (pers. comm.), one of the microfinance's expert in the research area, said:

Profit and loss-sharing scheme, as the main scheme of the Islamic MFIs was not fully used by the institutions due to poor accounting of their clients. Consequently, their clients prefer to choose other simple contracts instead of profit and loss sharing scheme. Furthermore, the Islamic MFIs still used unclear financial transaction particularly on the profit and loss sharing scheme, since the percentage of the scheme was unfair yet.

\section{Box 8.2: Local government's policies on poverty alleviation}

We interviewed politicians and village leaders concerning government policies on poverty alleviation. The first interviewee was H. Irsyad Yusuf, a politician from the National Revival Party (PKB) and a leader of the regional parliament of Pasuruan Regency. Regarding policies provided by the local government, he said, "Our local government collaborates with the local government of East Province to allocate funds for building and renovating standard housing for the poor."

Muzaki was our second respondent, a politician from the Democratic Party (PD) and a member of the regional parliament in Pasuruan Regency. On government policies, he said, "Our local government developed financial institutions, including woman cooperatives, through intensive collaborations with local entrepreneurs. We also recommended giving direct financial support for education, household renovation for the very poor, and job creation through the planting of pohon jarak (R. communis)."

The third was Irfan Zainullah, a village leader of Kertosari, in the upland area of Purwosari Subdistrict. Concerning policies on poverty alleviation provided by the local government, he said, "The local government optimizes and supervises the poverty alleviation program such as P2KP, PNPM, Gapoktan, Pokja, Kopwan, BOS and DAK from the central government."

Muhammad Sholeh, our fourth respondent, was a village leader of Plinggisan, in the lowland area of Kraton Subdistrict. On local government policies, he said, "Our local government provides soft loans to the poor people in our region through PNPM and Kopwan. These financial services worked well because the people were willing to repay installments." 


\subsubsection{THE EFFECTS OF ISLAMIC AND CONVENTIONAL MFIS ON ENVIRONMENTAL AWARENESS}

As financial intermediaries between larger investors and local communities, MFIs had close interactions with their clients. Thus, MFIs had the opportunity to have a positive effect on the environment, by being able to encourage their clients to use their loans for safe and eco-friendly business practices. In our research areas, the MFIs' clients usually used their loans for starting a business or enlarging the size of an existing one, or balancing their incomes. Their businesses generally affected the environment, as was the case in a study by Wenner, Wright, and Lal (2004), who found that small and micro businesses had an impact on environmental pollution within industrial areas.

\subsubsection{Training and Social Programs Provided by MFIs Related to Environmental Issues}

The MFI clients of our research areas generally based their economic activities around the natural resources in their surrounding environments. The inhabitants of the lowland area, with its fertile land, planted rice, corn, soybeans, and other crops for their main income. Those in the coastal area relied on marine products by fishing. A large percentage of people in all three regions also derived their incomes from off-farm occupations. Although, as Wenner, Wright, and Lal (2004) allude, these livelihood activities generally had less of an impact on the environment than some large-scale industries, the accumulative pollution still created serious environmental damage. In our case, the occupational safety issues affected both the environment and the health of the local communities.

As examples of the environmental pollutions in our research sites, brick-making caused air pollution and created health risks when bricks were burned using wood with gasoline on it, or plastic, tires, and used tires; furniture processing affected waste accumulation and enabled unsustainable logging practices; the over-use of chemical when farming negatively impacted soils; unsustainable fishing caused coastal ecosystem loss; and land and mangrove conversion to brackish fish ponds caused habitat loss for a large number of flora and fauna.

Since MFI clients derived their income based on local resources, capacity building as well as training on environmental issues should help them be more aware of natural sustainability. Especially as the clients usually already had good relationships with their institution because of intensive visits from MFI officials, particularly those from Islamic MFIs. 
Table 8.23: Social programs provided by the MFIs.

\begin{tabular}{lrr}
\hline Do MFIs provide some social programs? & Islamic MFIs (\%) & Conventional MFIs (\%) \\
\hline Yes & 21.11 & 10.00 \\
No & 65.56 & 31.11 \\
Don't know & 13.33 & 58.89 \\
Total & 100.00 & 100.00 \\
\hline
\end{tabular}

$\mathrm{N}=180$ (90 per type). Source: fieldwork.

Table 8.23 shows that a minority of respondents in both MFI types reported that their MFI provides social programs; $21.11 \%$ of the Islamic MFI clients, and $10 \%$ of the conventional MFI clients. Of the rest, most Islamic MFI clients (65.56\%) reported that their MFI did not provide any social programs, while most of the conventional MFI clients (58.89\%) did not know whether their MFI provides them. Although Islamic and conventional MFIs provided social programs, these data indicate that both types had a limited number of environmentally-oriented social programs available for their clients. Both types should increase the scale of their programs to cover a wider group of clients, by giving aid after natural disasters to a wider number of communities, providing trash facilities, creating social groups tasked with maintaining the environment, supporting house renovations for the poor geared toward reducing household waste, and conducting training on eco-friendly business practices.

We interviewed clients regarding the environment. Most clients of Islamic and conventional MFIs said that they did not face any problems in maintaining their environment (Table 8.24).

Table 8.24: Environmental problems faced by the respondents.

\begin{tabular}{lrr}
\hline $\begin{array}{l}\text { Do you perceive any problems in } \\
\text { maintaining the environment? }\end{array}$ & Islamic MFIs (\%) & Conventional MFIs (\%) \\
\hline Yes & 5.56 & 24.44 \\
No & 94.44 & 75.56 \\
\hline Total & 100.00 & 100.00 \\
\hline
\end{tabular}

$\mathrm{N}=180$ (90 per type). Source: fieldwork.

While the majority of clients of both types reported having no problems, this was the case with a higher percentage of the Islamic MFIs' clients, with $94.44 \%$, compared with those of the conventional MFIs, with $75.56 \%$ (Table 8.24). These comparable percentages may suggest that a large number of people in these areas felt that maintaining the environment was within their capabilities. They may also suggest a complacency on their part, as we observed environmental degradation in locations beset by illegal logging and land conversion for tambak ikan, and severe environmental pollution near water sources and in farmland, such as the throwing of garbage into 
rivers and burning of harvested crop waste near village centers. It is probable that a portion of the 94.44\% and $75.56 \%$ did not perceive unsustainable logging or fishing, or inefficient waste management, as environmental issues, and therefore did not take them into account as factors in maintaining the environment. Conversely, it is possible that the $5.56 \%$ of the Islamic MFI clients and $24.44 \%$ of the conventional MFI clients were more environmentally aware than their counterparts, and felt that maintaining the environment was beyond their own abilities. Religious teachings and local culture, which emphasize environmental protection and community spirit, may have a greater influence than financial institutions on creating environmental awareness and furthering the cause of environmental conservation in these regions.

Additionally, the clients were asked of their responses to environmental damages (Table 8.25).

Table 8.25: Reaction of MFI clients to environmental damage.

\begin{tabular}{lrr}
\hline $\begin{array}{l}\text { How would you react to damage to } \\
\text { your environment? }\end{array}$ & Islamic MFIs (\%) & Conventional MFIs (\%) \\
\hline $\begin{array}{l}\text { I will report to the village leader or } \\
\text { village organizations. }\end{array}$ & 22.22 & 15.56 \\
$\begin{array}{l}\text { I will reduce the environmental } \\
\text { damage to the best of my ability. }\end{array}$ & 28.89 & 50.00 \\
$\begin{array}{l}\text { I will invite my neighbor(s) to help } \\
\text { me improve the environment's }\end{array}$ & 46.67 & 33.33 \\
$\begin{array}{l}\text { condition. } \\
\text { Other. }\end{array}$ & 2.22 & 1.11 \\
\hline Total & 100.00 & 100.00 \\
\hline $\mathrm{N}=180(90$ per type) Source fieldwork. & &
\end{tabular}

$\mathrm{N}=180$ (90 per type). Source: fieldwork.

A higher of percentage of clients of the Islamic MFIs (46.67\%) compared with those of the conventional MFIs (33.33\%) stated that, in the event of environmental damage, they would invite their neighbor(s) to help them improve the environment's condition (Table 8.25). Meanwhile, a higher percentage of clients of the conventional MFIs (50\%) compared with those of the Islamic MFIs (28.89\%) stated that they would reduce the damage themselves, to the best of their ability. These data may be related to the percentage of clients who were self-employed in off-farm enterprises (Table 8.11), where clients of Islamic MFIs outnumbered those of conventional MFIs. Clients of conventional MFIs self-employed in agriculture in turn outnumbered those belonging to Islamic MFIs. In general, those working in industries such as food processing, brick making, and petty trading had more freedom to partake in social activities, compared with those in agriculture, because they were able to abide by their own schedules. Consequently, these respondents would be more able to partake in, as well as more familiar with, 
more social solutions to environmental damage. Contrasting that, farmers had more rigorous working hours, and therefore were less able to take part in social activities and more accustomed to working on their own, suggesting a further connection between occupation and environmental damage response preference. A comparable number of clients from both types stated that they would simply report the damage to the village leader/organizations, 22.22\% of the Islamic MFI clients and $15.56 \%$ of the conventional MFI clients. One responsibility of a village leader is to manage the local environment. Thus, these low percentages might indicate less a lack of environmental awareness than a belief in deferment to authority and that maintaining the environment should be the responsibility of those with the power to do so.

In general, the social cohesion of the people had a positive effect environmental improvement, in conjunction with MFIs participation through social programs. The key informants in our research areas offered some solutions to MFIs in mitigating environmental degradation (Table 8.26).

Table 8.26: Solutions to reducing environmental damage.

\begin{tabular}{lccr}
\hline Solution & $\begin{array}{c}\text { No. of expert } \\
\text { respondents }\end{array}$ & Percent \\
\hline $\begin{array}{l}\text { Islamic MFIs should collaborate with other agencies to } \\
\text { encourage eco-friendly business practices. }\end{array}$ & 5 & 22.73 \\
$\begin{array}{l}\text { Islamic MFIs should add their financing to agricultural } \\
\text { sector including seeds plantation program. }\end{array}$ & 3 & 13.64 \\
$\begin{array}{l}\text { MFI should provide training on environmentally } \\
\text { friendly business practices. }\end{array}$ & 7 & 31.82 \\
$\begin{array}{l}\text { Islamic MFIs should provide waste management } \\
\text { solutions and build permanent latrines. }\end{array}$ & 4 & 18.18 \\
No opinion. & 3 & 13.64 \\
\hline Total & & 22 & 100.00 \\
\hline
\end{tabular}

$\mathrm{N}=$ 22. Source: Key informant interviews.

Most of our expert respondents (54.55\%) recommended that MFIs encourage eco-friendly friendly business practices from their clients, whether by themselves (seven people; 31.82\%) or with the assistance of other agencies (five people; 22.73\%). A slightly smaller number suggested that MFIs instead take a more proactive approach, such as installing permanent latrines (four people; $18.18 \%$ ), or add their financing to agricultural sector including seeds plantation program (three people; 13.64\%). 


\subsubsection{Knowledge and Behavior Changes on Specific Environmental Issues after Joining MFIs}

Environmental degradation influenced clients' health and safety, and, consequently, their sustainable development. Education level and knowledge of how to maintain the environment affected their environmental awareness. Additionally, MFIs' social programs on environmental issues also contributed to raising the awareness and conservation interest of their clients. However, we could not exclude the strong influences of local culture and religious belief. Respondents from both Islamic and conventional MFI were interviewed on their knowledge of environmental matters, MFIs' roles, and environmental awareness as the result of joining a microfinance institution.

Table 8.27: Clients’ knowledge of specific environmental issues.

\begin{tabular}{lrrrr}
\hline \multirow{2}{*}{ Are you aware of these issues? } & \multicolumn{2}{c}{ Islamic MFIs } & \multicolumn{2}{c}{ Conventional MFIs } \\
\cline { 2 - 5 } & Yes (\%) & No (\%) & Yes (\%) & No (\%) \\
\hline Air pollution & 91.11 & 8.89 & 67.78 & 32.22 \\
Water pollution & 91.11 & 8.89 & 62.22 & 37.78 \\
Hazardous chemical waste & 92.22 & 7.78 & 56.67 & 43.33 \\
Organic pollutants & 84.44 & 15.56 & 61.11 & 38.89 \\
Chemical fertilizers & 85.56 & 14.44 & 67.78 & 32.22 \\
Unsustainable fishing & 76.67 & 23.33 & 58.89 & 41.11 \\
Land degradation & 80.00 & 20.00 & 60.00 & 40.00 \\
Environmental regulation & 93.33 & 6.67 & 70.00 & 30.00 \\
compliance & & & & \\
Harmful waste disposal & 95.56 & 4.44 & 72.22 & 27.78 \\
\hline
\end{tabular}

$\mathrm{N}=180$ (90 per type). Source: fieldwork.

The majority of clients of both Islamic and conventional MFIs reported that they were aware of all our listed environmental issues (Table 8.27). However, across all of the issues, a greater percentage of clients of Islamic MFIs were found to be aware, compared with those of the conventional MFIs. Amongst Islamic MFI clients, the highest awareness was of harmful waste disposal (95.56\%), followed by environmental regulation compliance (93.33\%), hazardous chemical waste (92.22\%), and air and water pollution (91.11\% each). Meanwhile, the lowest awareness was of unsustainable fishing (76.67\%), followed by land degradation (80\%), organic pollutants (84.44\%), and chemical fertilizers (85.56\%). Similarly, conventional MFI clients had the highest awareness of harmful waste disposal (72.22\%), environmental regulation compliance (70\%), and air pollution and chemical fertilizers (67.78\% each). The lowest awareness was of hazardous chemical waste (56.67\%), followed by unsustainable fishing (58.89\%), land degradation (60\%), and organic pollutants (61.11\%). 
The prominence of certain issues was similar between the two MFI types. Harmful waste disposal was the source of the highest environmental awareness, followed by environmental regulation compliance. Conversely, the lowest awareness amongst clients of both MFI types was of unsustainable fishing and land degradation. One factor behind this was the coastal area's low percentage compared with the lowland and upland areas (Table 8.7). Despite the coastal area's dependence on fishing, it showed far less awareness of unsustainable fishing than the other two areas (48.33\% to $81.67 \%$ and $73.33 \%$ in the lowland and upland areas, respectively). Because our respondents had knowledge of individual environmental issues, increasing their environmental awareness as a whole was possible. Targeting the areas of low awareness may be the best method for the government, NGOs, and MFIs to combat low environmental concern and encourage the preservation of both urban and rural peoples’ surrounding environments.

The clients who reported having knowledge of a specific issue were then asked whether their MFIs training or social program had an effect on creating that awareness.

Table 8.28: Contribution of MFIs to knowledge of specific environmental issues.

\begin{tabular}{lrrrrrr}
\hline If you are aware of the following & \multicolumn{3}{c}{ Islamic MFIs } & \multicolumn{3}{c}{ Conventional MFIs } \\
\cline { 2 - 8 } $\begin{array}{l}\text { issues, is your awareness the result } \\
\text { of your MFI? }\end{array}$ & $\mathrm{N}$ & $\begin{array}{r}\text { Yes } \\
(\%)\end{array}$ & $\begin{array}{r}\text { No } \\
(\%)\end{array}$ & $\mathrm{N}$ & $\begin{array}{r}\text { Yes } \\
(\%)\end{array}$ & No (\%) \\
\hline Air pollution & 82 & 2.44 & 97.56 & 61 & 8.20 & 91.80 \\
Water pollution & 82 & 2.44 & 97.56 & 56 & 10.71 & 89.29 \\
Hazardous chemical waste & 83 & 3.61 & 96.39 & 51 & 11.76 & 88.24 \\
Organic pollutants & 76 & 0.00 & 100.00 & 55 & 10.91 & 89.09 \\
Chemical fertilizers & 77 & 5.19 & 94.81 & 61 & 9.84 & 90.16 \\
Unsustainable fishing & 69 & 0.00 & 100.00 & 53 & 7.55 & 92.45 \\
Land degradation & 72 & 4.17 & 95.83 & 54 & 11.11 & 88.89 \\
Environmental regulation & 84 & 2.38 & 97.62 & 63 & 11.11 & 88.89 \\
compliance & & & & & & \\
Harmful waste disposal & 86 & 3.49 & 96.51 & 65 & 9.23 & 90.77 \\
\hline
\end{tabular}

Source: fieldwork.

Only a very small percentage of clients, of both types, believed their MFI had an impact on their awareness of a specific issue (Table 8.28). The percentage of conventional MFI clients who felt this was the case, however, was higher in every single issue. The greatest difference was in clients' awareness of organic pollutants; $10.91 \%$ of the conventional MFI clients reported their MFI to have had an impact on their awareness, while none (0\%) of the Islamic MFI clients felt their MFI had an effect. Conventional MFIs appeared to have the highest impacts on the awareness of hazardous chemical waste (11.76\%), land degradation and environmental 
regulation compliance (11.11\% each), organic pollutants $(10.91 \%)$, and water pollution (10.71\%). On the other hand, the lowest contributions were to the awareness of unsustainable fishing (7.55\%), air pollution (8.20\%), harmful waste disposal (9.23\%), and chemical fertilizers (9.84\%). Of the Islamic MFIs, the highest contributions to the awareness of individual issues were to chemical fertilizers (5.19\%), land degradation (4.17\%), hazardous chemical waste (3.61\%), and harmful waste disposal (3.49\%), while the lowest contributions were to organic pollutants and unsustainable fishing (0\%), environmental regulation compliance (2.38\%), and air and water pollution (2.44\%).

Not only was there a great difference in the impact of the conventional MFIs on the awareness of their clients on specific environmental issues compared with that of the Islamic MFIs, but there was a difference in which issues clients considered to have been affected by their MFI's training or social programs. For example, whereas conventional MFIs had the greatest impact on hazardous chemical waste awareness, Islamic MFIs had the greatest impact on chemical fertilizer awareness. MFIs in different regions emphasizing one environmental issue over another may be the cause of this disparity, particularly when that issue has a greater effect on that region's surrounding environment. However, that would contradict our data showing unsustainable fishing to be the issue on which MFIs had the lowest impact. With clients of both types having lower awareness of this issue than the others, and MFIs failing to have any impact on their awareness of it, suggests that MFIs in general may have struggled to educate their clients on environmental issues whose consequences affected them the most.

Table 8.29: Changes to environmental awareness after joining an MFI.

\begin{tabular}{|c|c|c|c|c|c|c|}
\hline \multirow{2}{*}{$\begin{array}{l}\text { Did your behavior towards these } \\
\text { issues change after you joined your } \\
\text { MFI? }\end{array}$} & \multicolumn{3}{|c|}{ Islamic MFIs } & \multicolumn{3}{|c|}{ Conventional MFIs } \\
\hline & $\mathrm{N}$ & $\begin{array}{l}\text { Yes } \\
(\%)\end{array}$ & $\begin{array}{l}\text { No } \\
(\%)\end{array}$ & $\mathrm{N}$ & $\begin{array}{l}\text { Yes } \\
(\%)\end{array}$ & $\begin{array}{l}\text { No } \\
(\%)\end{array}$ \\
\hline Air pollution & 82 & 13.41 & 86.59 & 61 & 22.95 & 77.05 \\
\hline Water pollution & 82 & 17.07 & 82.93 & 56 & 25.00 & 75.00 \\
\hline Hazardous chemical waste & 83 & 13.25 & 86.75 & 51 & 27.45 & 72.55 \\
\hline Organic pollutants & 76 & 7.89 & 88.31 & 55 & 27.27 & 72.73 \\
\hline Chemical fertilizers & 77 & 11.69 & 88.31 & 61 & 26.23 & 73.77 \\
\hline Unsustainable fishing & 69 & 8.70 & 91.30 & 53 & 20.75 & 79.25 \\
\hline Land degradation & 72 & 12.50 & 87.50 & 54 & 22.22 & 77.78 \\
\hline $\begin{array}{l}\text { Environmental regulation } \\
\text { compliance }\end{array}$ & 84 & 10.71 & 89.29 & 63 & 26.98 & 73.02 \\
\hline Harmful waste disposal & 86 & 10.47 & 89.53 & 65 & 27.69 & 72.31 \\
\hline
\end{tabular}

Source: fieldwork. 
The results shown in Table 8.29 agree with those of Table 8.28: while both MFI types were shown to have little impact on the environmental behavior of their clients, conventional MFIs still proved to be consistently more effective than Islamic MFIs. Similarly, organic pollutants was the category that accounted for the largest disparity between the two types, $27.27 \%$ of the conventional MFI clients compared with just $7.89 \%$ of the Islamic MFI clients. Issues that saw the greatest behavioral changes amongst conventional MFI clients were harmful waste disposal (27.69\%), hazardous chemical waste (27.45\%), organic pollutants (27.27\%), environmental regulation compliance (26.98\%), and chemical fertilizers (26.23\%), while the lowest behavioral changes occurred with unsustainable fishing (20.75\%), land degradation (22.22\%), and air and water pollution (22.95\% and 25\%, respectively). Meanwhile, the greatest behavioral changes amongst Islamic MFI clients were water pollution (17.07\%), air pollution (13.41\%), hazardous chemical waste (13.25\%), land degradation (12.5\%), and chemical fertilizers (11.69\%). Conversely, the lowest changes to clients' behavior were to organic pollutants (7.89\%), unsustainable fishing (8.7\%), harmful waste disposal (10.49\%), and environmental regulation compliance (10.71\%).

A consistently lower percentage of clients reported that their MFI had an effect on their awareness of a specific issue than those who reported their behavior changing as the result of their MFI, suggesting that although MFIs had a minimal impact on awareness, they had greater success in influencing the environmental behaviors of their clients. Reasons for this, on the Islamic microfinance side, may be clients' associations of their MFI with Islamic teachings and law (specifically on environmental issues), while conventional MFIs' longer tenure in these regions, as well as the lower flexibility of their loaning schemes, may account for their higher percentages. Clients of conventional MFIs, in particular, had an interest in maintaining certain practices that enabled them to repay their loans. Environmental disasters as the result of their behaviors, such as flooding caused by soil erosion and draining water into rivers, harmed them more than clients of Islamic MFIs, particularly when their occupations were associated with higher risks - as was the case with agriculture-and thus increased the interest rates of their loans. 


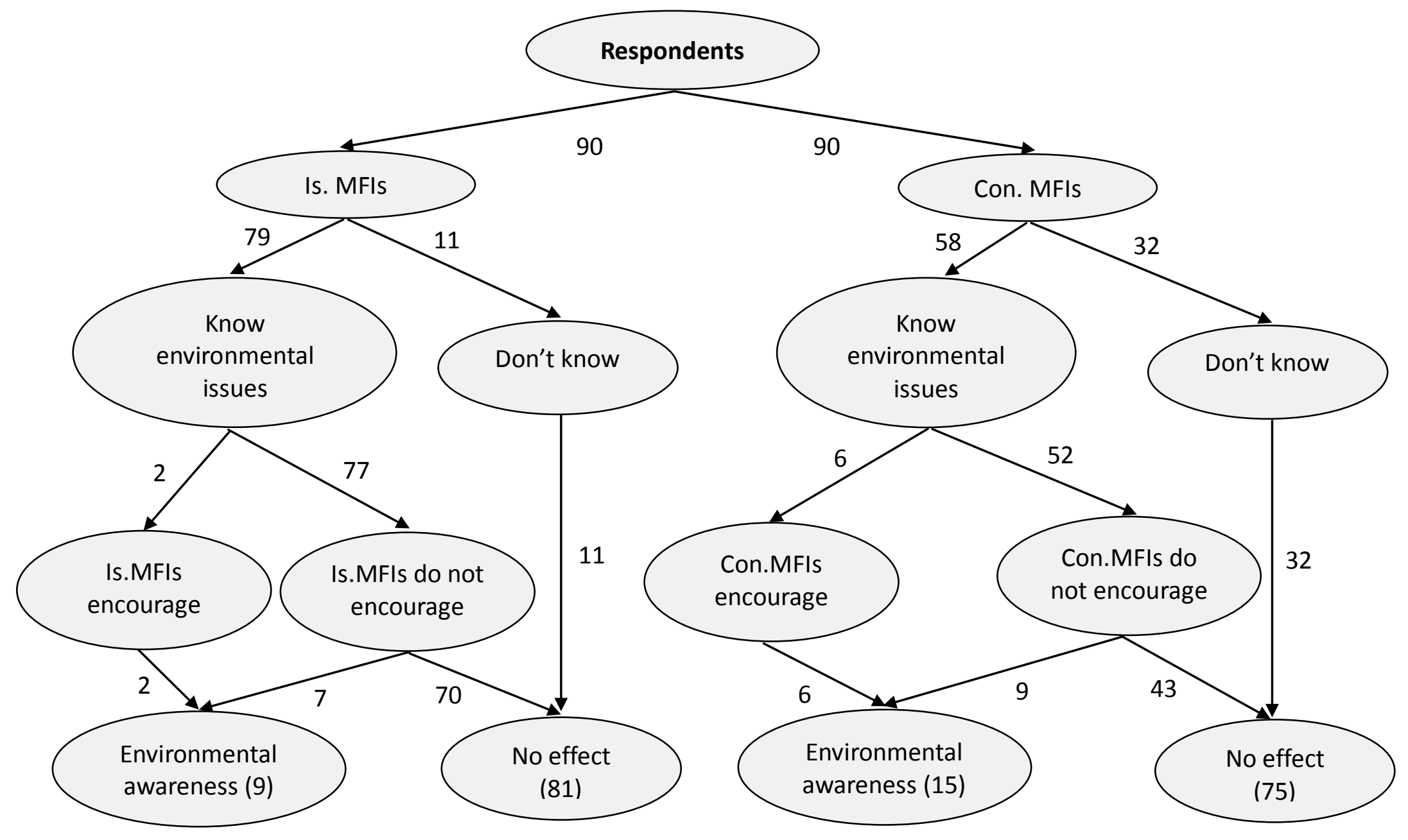

Figure 8.7: Flowchart of the effects of MFIs’ financing/loan on environmental awareness. 
Neither type of microfinance institution had a more than a minor impact on the environmental awareness of their clients (Figure 8.7). Of the Islamic MFIs, 81 clients (90\%) reported that their MFI did not have an effect on their environmental awareness, while 75 clients (83.33\%) of the conventional MFIs reported the same. Just nine Islamic MFI clients (10\%) and 15 conventional MFI clients (16.67\%) reported that their MFI had an impact on their environmental awareness.

\section{Box 8.3: Local government's policies on environmental awareness}

We conducted in-depth interviews with politicians and village leaders regarding their local government's policies on environmental awareness. The first respondent was Syamsul Hidayat, a politician from the National Revival Party (PKB) and a member of the regional parliament of Pasuruan Regency. Regarding government policies on environmental awareness, he said, "Our local government of Pasuruan Regency allocates funds from the central government to rehabilitation programs, particularly in the coastal and upland areas, which provide seeds for farmers."

Amak Hanafi, the second respondent, was a village leader of Gambir Kuning, in the lowland area of Kraton Subdistrict. In connection with government policies, he said, "We provide trash cans for the people and encourage them to build permanent latrines, so that about $50 \%$ of people in this village will not bath, wash, or defecate in the river."

The third respondent was Chuzaimi, a village leader of Kedawang, in the coastal area of Nguling Subdistrict. Concerning the role of local authorities in environmental awareness, he said, "We conduct regular environmental maintenance, such as planting mangroves, through collaboration between people, local government, and the processing industry. We also collaborate with water police to encourage local people not to use hazardous chemicals to catch fish."

Muhammad Kasihan was the fourth respondent, a village leader of Bakalan. On his responsibilities as a village leader, he said, "With the help of some local students, we planted teak (Tektona grandis) and sengon (Albizia chinensis) in the Babakan village area. This was done on sidewalks, to provide shade and prevent erosion, as well as generate some income for the local community." 
Our findings in this chapter show that Islamic MFIs have a greater impact than conventional MFIs on poverty alleviation. Some factors such as flexibility in installment payment, more fund sources, and the prevalence of soft loans are the likely causes. These findings will affect the already positive demand for Islamic microfinance, especially when conventional MFI clients learn of Islamic MFIs' financing policies and how, if at all, they may affect them. Haque, Sayeedul, and Yamao (2011), in a study on the prospects and challenges of Islamic microfinance in Bangladesh, revealed that all Muslim respondents were motivated to apply for conventional MFIs' services when there were no Islamic MFIs within their area. This shows that there is a demand for microfinance, regardless of type, although our results indicate that Islamic MFIs, were they available, would have seen a greater number of clients than conventional MFIs.

In terms of promoting environmental awareness, both Islamic and conventional MFIs had low impacts. Limited training, as well as social programs, might be cause of the low level of environmental awareness amongst the clients. Although most of the Islamic MFI clients said that they did not perceive any problems in maintaining the environment, our direct observations showed little concern for the environment. Waste was commonly found beside rivers and coasts, as well as traditional latrines over rivers, and locals would burn agricultural waste as opposed to recycling or re-using it.

Our data also revealed that while both MFI types had an impact, Islamic MFIs, in particular, affected the welfare of their clients, as shown in their improvements in consumption, education, and health care. However, the fact that Islamic MFIs did not allocate any financing towards ecofriendly businesses and had limited programs on environmental issues contributed to their inability to impact their clients' environmental awareness and behaviors. Hence, green microfinance, having a greater focus on environmental preservation, was not successful in our research areas. The Islamic MFIs still focused on providing their financial services to low risk business. Environmentally-friendly businesses, however, were associated with high costs and risk. 


\section{Discussion}

\subsection{Geographical Comparison between the Lowland, Coastal, and Upland Areas' Microfinance Institutions’ Impacts on Poverty Alleviation and Environmental Awareness}

\subsubsection{Institutional Performance}

In general, there were no differences between the three research areas, in terms of the individual characteristics of the microfinance institution (MFI) clients. The vast majority of heads of household were male, married, literate, and Muslim. Factors that have possible impacts on alleviating poverty and increasing environmental awareness, specifically education, main occupation, and wealth, however, differed greatly. As the oldest educational institutions in Indonesia, pondok pesantren contributed to the development of Islamic MFIs in the lowland area. Through students' social services, such as teaching and training on proper business conduct, perceptions of Islamic MFIs amongst locals were affected by the pondok pesantren. In the coastal area, Islamic MFIs succeeding failed institutions experienced some constraints and challenges during their establishment, because of people's poor experiences with their defunct, less competent predecessors. But, by 2011, communities in this area were found to be more receptive of Islamic MFIs, as seen in the increased prevalence of qard al hasan, which increased from 9\% in 2009 to 20\% in 2011 (Mambaul Ulum, pers. comm.). Islamic MFIs in the upland area used Islamic approaches and customs, such as the use of religious meetings and Islamic clothing, to differentiate themselves from other institutions. Nevertheless, the reach of the institutions was limited to graduates of pondok pesantren and those who recognized the Islamic MFIs’ officials.

Meanwhile, conventional MFIs in the lowland area provided credit to farmers for the purposes of acquiring seeds and fertilizer. The people also had greater flexibility than they would otherwise have from an informal institution (such as a money lender or relative), since their institutions allowed them to repay their credit with the revenues of their harvest, which was often three or four months later. Conventional MFIs in the coastal area focused on providing their services to fisheries and small entrepreneurs whose businesses were based mostly on marine products. However, the imbalanced financing and loaning services provided by these MFIs created a market opening for other financial institutions. Conventional MFIs competed with other financial institutions by looking for the best methods of maintaining their financial performance. In the 
upland area, because it was mountainous and required extra costs when communities were provided with credit and savings services, they would use community leaders in each village as an agent tasked with looking for potential clients. Overall, both Islamic and conventional MFIs in the three different regions always looked for the most financially sustainable strategies, attempting to maintain financial performance and increase targeted client reach within a regional context.

\subsubsection{The EfFect of MFIs ON Poverty Alleviation}

The establishment of microfinance institutions can have positive effects on alleviating poverty, since borrowers are able to increase consumption and improve housing (Berhane and Garderbroek 2011), particularly in cases where they are able to reach communities with a wide range of industries, as Babandi (2011) found to be the case in Nigeria, and proved to be relevant in our research, with the different research areas' communities all being based on different natural resources. Microcredit schemes elsewhere in East Java have been successful in targeting and improving the welfare of the poor, but less successful in improving other household outcomes, such as education and health care (Takahashi, Higashikata, and Tsukada 2010). Correspondingly, our findings showed that MFIs played a role in increasing clients' families' welfare. MFIs had a major positive effect on their clients' businesses in all three research sites, although the lowland and coastal areas showed slightly more positive effects than the upland area. Several causes of these positive impacts may be age of business, governmental policies favouring certain regions, and number of employees. Regarding age of business, the lowland area was revealed to have earlier business development than the other regions, with the region's proximity to the city of Pasuruan, enabling people in the lowland area to more easily sell their agricultural products, being a possible contributor.

A significant majority of the respondents in all three areas were able to develop their business as a result of receiving financing or loans from a microfinance institution. A higher percentage of respondents from the lowland and coastal areas (85\% each) reported this to be the case, compared with $75 \%$ from the upland area, indicating that MFIs from the lowland and coastal areas had slightly more positive effects on clients' businesses. However, 25\% of the respondents in the upland area (and 15\% in both the lowland and coastal areas) still reported no effect on the development of their business, suggesting that the MFIs still needed more time to develop their own institutions and further provide both financial and non-financial services to their clients. Thus, longer membership may have a positive effect on business development, particularly in light of Parvin and Shaw's (2013) findings on perceptions of MFI support for disaster risk 
reduction, response, and recovery, who saw a positive correlation between membership period and client disaster preparedness, response, and recovery. Our respondents who successfully developed their businesses reported higher profits and food consumption, as well as ability to increase their business size. However, these respondents had lower food consumption than those who were less successful in developing their businesses, suggesting a dilemma between food consumption and business development, although higher concern for the future of their business, which was the case with the majority of respondents, was likely to have a better long-term impact on their welfare, and enable sustainable long-term food consumption, at the cost of reduced short-term consumption.

A study by Afrane (2002) reviewing the impact of microfinance intervention revealed that, as a result of increasing business income after adopting microfinance, MFI clients were able to improve housing, education, food consumption, and health care. Our findings revealed that business development as the result of MFI establishment contributed positively to family welfare, and household expenditures. MFIs played a significant role in poverty alleviation in the lowland area of Kraton Subdistrict, as clients saw improvements in business size and net profit. Other benefits, such as income from crops and off-farm activities, farmland area, and capital to spend on durable assets and agricultural inputs, also increased, in accord with the results of Morris and Barnes (2005). In addition, we found that MFIs in the coastal area of Nguling Subdistrict positively affected the economic activities carried out by the communities. Both the welfares of families and states of their businesses were improved after they received financing or credit from MFIs. Crawford (2007) found that MFIs have a chance to minimize the impact of money lenders and increase economic empowerment in coastal communities. While this was certainly true of our research site, MFIs nevertheless struggled to compete with other semiformal and formal institutions—such as banks and institutions from neighboring regions-and thus, despite exploitative lending practices being reduced, optimal financial performance was still not achieved. Ruben and Clercx (2003) conducted a study in an upland area of Honduras, and found that access to rural finance reinforced food security and enabled income diversification, in accord with our results in the upland area of Purwosari Subdistrict, which revealed that clients were able to use the extra money generated from their credit or financing schemes to balance their incomes with their expenditures, and be provided with capital for their business.

However, regarding policies on economic development and investment, we found that the lowland area required more attention from decision-makers, since the respondents of this area 
spent less of their surplus income on increasing the size of their business, compared with those in the upland and coastal areas. Giving additional land to low income farmers and allowing the land market to develop, which are both parts of the government's poverty reduction program, may increase farmer benefits, as was also suggested in previous research (Lerman 2008). Nevertheless, serious attention through the government's poverty alleviation programs should also be given to the people in the upland and coastal areas, because close interaction between the government and the poor through MFIs increases the chance of sustainable development succeeding (Kaushal and Kala 2005).

\subsubsection{THE EFFECT OF MFIS ON AWARENESS OF SPECIFIC ENVIRONMENTAL ISSUES}

Microfinance institutions have an ability to impact environmental awareness, through the use of social programs and environmental awareness training, particularly in locations where borrowers generate much of their income from natural resources. Rouf (2012b) found MFIs in both Bangladesh and Canada to have positive impacts on sustainable environmental development. Our comparisons of MFI clients' knowledge on specific environmental issues revealed several consistencies within each region, and a slight inconsistency, overall. The majority of the respondents in the lowland and upland areas reported awareness of every issue listed in our questionnaire (air pollution, water pollution, hazardous chemical waste, organic pollutants, chemical fertilizers, unsustainable fishing, land degradation, environmental regulation compliance, and harmful waste disposal). Conversely, of the majority of the coastal area's respondents were aware of only three of the nine issues. Unsustainable fishing, across all three research sites, had the lowest awareness. However, despite the region's dependence on fishing, the coastal area had by far the lowest awareness; $48.33 \%$ to the lowland area's $81.67 \%$ and upland area's 73.33\%. In the short- and long-term, unsustainable use of the resource base, along with industrialization, urbanization, and the de-conservation of natural resources (Reddy, Kumar, and Padmavathi 2013), affects habitats and consequently contributes to environmental degradation. Ahmed et al. (2013) found overfishing, destructive use of fishing gear, water pollution, siltation, rapid urbanization, and human encroachment to be causal factors in declining fish populations in Old Brahmaputra River in Bangladesh. Both ecosystem health and the future of small-scale fishing were consequently threatened. In our study, we found low education, training, capacity building, and age of business to be the possible causes of the low awareness of the peoples in the research areas. White and Hunter (2009) undertook a study in Coastal Ghana on environmental policy issues, which revealed that education and political engagement significantly contributed to environmental awareness. Minimizing the economic and 
environmental awareness disparity between the coastal area and the lowland and upland areas will require greater effort from governmental agencies, NGOs, and MFIs. While factors such as poverty and few income alternatives may cause resource overexploitation, they do not account for lack of awareness. Because of the dearth of adequate research into the coastal area's inhabitants and ecosystem, the exact reason for the region's lower awareness on an issue that affects it the most is presently left to speculation. Further and more detailed research specifically focusing on the coastal area may better reveal the causes and effects of low environmental awareness on communities that are dependent on marine and a limited range of resources, both here and elsewhere.

Some experts have claimed that MFIs could play a role in fostering pro-environmental behaviors among their micro entrepreneur clients (Allet 2012). However, our analyses revealed that the MFIs in all three areas had problems with providing environmental training to their clients, exasperating an already existent lack of attention. In all three regions, more respondents reported that they did not receive training from their MFI than those who did. In the lowland area of Kraton Subdistrict, traditional latrines over rivers were commonly found, even near traffic-heavy inter-regency roads. At the same time, people were observed using water from these rivers for bathing, and washing clothes and household furniture. The socioeconomic conditions of the people affected the quality of their surrounding environment. Access to drinking water and the availability of permanent toilet and bathroom facilities at home are some indicators of good sanitation. Shortall (2009) pointed out that polluted water causes diseases and contaminates larger ecosystems, as does the overuse of agricultural inputs, which pollute fields. The existence of MFIs in the coastal area of Nguling Subdistrict had a low impact on the communities' environmental concerns, since they were not provided with training and social programs on environmental issues. Based on direct observations, the local people still had limited awareness of the effects of their routine business activities, such as the proximity of their sun-dried fish to coastal trash or the heavy amount of smoke generated by their fish-grilling processes. Thus, the environmental awareness of the communities within the area as a whole had little positive impact because many of the people had little knowledge of environmental issues. Providing training programs, as pointed out by Olli, Grendstad, and Wollebaek (2001), can help in the persuasion of uneducated people to increase their awareness on environmental issues. Additionally, amongst the majority of respondents in the upland area of Purwosari Subdistrict, initiatives to either improve the environment themselves or, more commonly, with their neighbors were common. In spite of that, however, we found respondents' overall environmental awareness to be limited. 
Limited environmental knowledge on the part of their officials and little financial support from MFIs might be additional factors in the MFIs' low impacts on environmental awareness. Meanwhile, Wenner, Wright, and Lal (2004) reported that MFIs have opportunities to encourage their clients to apply innovative, environmentally-friendly business practices by allocating credit schemes to businesses that emphasize these practices, and avoiding those that don't. By promoting environmental awareness, MFIs may benefit by limiting "their own exposure to lending risks due to environmental and occupational safety problems.”

Our data further indicate the low level of the MFIs' contributions to environmental awareness through social programs in their clients' claims that their institution did not provide those programs. MFIs were presented with a dilemma between investing their human and capital resources on environmental awareness or towards their own financial sustainability. MFIs elsewhere have had difficulties in building internal skills and conciliating their environmental and performance objectives, whilst failing to take into account the psychological, economic, and structural hindrances to behavior change, and not seeing the links between financial services and raising environmental awareness (Allet 2012). It might be costly for MFIs to dedicate a part of their net profit to environmental matters, but one cost-effective way to improve environmental awareness amongst clients may be to simply educate them of the existence of these training programs, rather than wasting resources on improving programs that in some cases may be sufficient.

Our respondents in all regions reported that they did not perceive any problems in maintaining the environment, although their institutions gave low environmental support. However, in our direct observations, many areas were polluted by large amounts of waste, some of which was consequently deposited into their respective rivers, which were utilized by local populations for their daily activities. Our analyses showed that they may not have received additional assistance from institutions to maintain their environment, since they reported that they did not perceive any problems in maintaining the environment, although social cohesion, local culture, and religious teaching and norms may have also played a role in this perception. In addition to the small impact of MFIs on environmental awareness in the three areas, our study revealed that a basic lack of knowledge in environmental issues might also have been a factor in the respondents' low environmental awareness. This was exasperated by the inadequate, small-scale training and social programs on environmental issues provided by the MFIs. As aforementioned, social cohesion, culture, and religion may have been factors in respondents' perceptions of the difficulty_or lack thereof_-in maintaining the environment. Arafat et al. (2007) found waste 
management perceptions to differ based on age, education, and residence. According to their respondents, the two best methods of decreasing littering were moral and religious convictions and increasing the availability of litter cans. Based on our observations and analyses, both of these methods would be applicable in all three research sites, especially the upland area, where one village leader specifically highlighted the need for more trash cans.

Research on microfinance's impact on environmental awareness in Indonesia is nonexistent, and very rare in the rest of the world. Our study suggests that cooperation is needed between the local and central government, NGOs and MFIs to encourage eco-friendly practices and environmentally-friendly businesses, since increasing environmental awareness can contribute to sustainable business practices and, therefore, poverty alleviation. The government may use the MFIs as a proxy by providing them with incentives to target clients with environmentallyfriendly businesses, and thus, its role as a policy- and decision-maker may prove helpful toward reaching the goals of environmental sustainability. Akca, Sayili, and Yilmazcoban (2007) also point out that the private sector, and both governmental organizations and NGOs should organize conferences, seminars, and meetings on environmental issues, while supporting the idea of rural people joining environmental organizations.

\subsection{A Comparative Analysis between Islamic and Conventional MFIs}

Many studies have revealed the important role of MFIs in combating poverty, especially in developing countries. However, there are still a limited number of studies on how Islamic MFIs affect the poverty alleviation of both the poor and the poorest. Moreover, to our knowledge, no studies exist that examine Islamic MFIs' effects on promoting environmental awareness amongst their clients. Our study was an attempt to investigate whether Islamic MFIs positively or negatively impact both poverty reduction and environmental awareness. The impacts of Islamic and conventional MFIs on both poverty alleviation and environmental awareness were compared to understand whether their systemic differences were contributing factors.

\subsubsection{Clients' Characteristics ANd Their Preferences in SAVING AND LoAN SERVICES}

There were slight differences between the clients of Islamic and conventional microfinance institutions, in terms of individual characteristics. These few differences, however, had little to no effect on MFI type selection, across all three research areas. Clients of both Islamic and conventional MFIs reported a preference for the savings schemes of Islamic MFIs. A significant majority of Islamic MFI clients also reported a preference for the financing of Islamic MFIs, 
while, of the convention MFI clients, a greater percentage also reported a similar preference over the loans of conventional MFIs. The Islamic MFIs' compliance with Islamic laws and their use of profit-sharing — as opposed to the interest-based schemes of the conventional MFIs-were the likely contributing factors to this discrepancy. These results were also found in previous research, in which most borrowers in communities that were predominantly Muslim showed a preference for Islamic MFIs over conventional MFIs (Masyita and Ahmed 2011). However, notably, the greatest considerations of the clients were based on economic aspects, such as low interest rates and collateral and loan size, instead of non-economic ones, which includes quality of service variables, easiness, speed, nearness, method, and a loan officer's profile.

\subsubsection{ASYMMETRIC INFORMATION}

Asymmetric information is one factor behind the occurrence of credit constraints in a market in which providing loans to borrowers with high risk is an accepted practice. Karlan and Zinman (2009) found stronger evidence of moral hazard than adverse selection in a South African study on asymmetric information, with $13 \%$ to $21 \%$ of defaults being caused by moral hazard. In our study, incidences of moral hazard were found in clients' usage of their financing or loans. Of the three categories, namely non-productive, income creation, and business development, $11.11 \%$ of Islamic MFI clients and 22.22\% of conventional MFI clients reported using their funds for nonproductive activities. This presented a moral hazard case, particularly when the fund's usage affected the ability of the client to repay their loan. The higher percentage of conventional MFI clients using their loans for non-productive purposes was possibly caused by their institutions' less strict usage rules compared with those of the Islamic MFIs.

Concerning the effectiveness of microfinance in minimizing asymmetric information, moral hazard, and adverse selection, a comparison between qard al hasan (credit without interest) and traditional microcredit in Iran by Bakhtiari (2009) revealed that qard al hasan is more efficient than microcredit. Financial institutions usually provided qard al hasan to familiar people situated in one region, special groups, or friends. Both institutions and clients were familiar with each other, and institutions were confident that financing going to the poorest would not be used for ulterior purposes. Hence, information between institution and client was symmetric and transparent, and moral hazard was uncommon. In our study, qard al hasan was the second-most adopted scheme, particularly amongst the poorest of the poor.

The most adopted scheme, however, was ba'i bi tsaman 'ajil. Paradoxically, the Islamic MFIs in our research areas who provided this scheme supplied money to their clients instead of goods, 
the latter being the customary method. While this meant there was less of a breach of Islamic law, more practical problems arose. Funds instead of goods came with the risk of moral hazard, that clients would use the funds for purposes contrary to those for which they applied, and which may affect the MFI should problems with repayment occur. These financial practices were contrary to those described by Hasan (1995), who argued that Islamic ethics have the possibility to mitigate the moral hazards and adverse selection of economic actors.

In general, in all three research areas, asymmetric information frequently occurred when the clients broke the contractual agreement they signed with their institution. Additionally, some MFI clients used their financing or loans for purposes other than those specified in their applications. Others would apply on behalf of other people, abusing the trust of the institutions. Social cohesion between institutions and trusted clients did not work well, while Jackson and Schneider (2011) show that social cohesion had a positive role as an incentive to reduce the effects of moral hazard. A further number of clients in our study used the funds acquired by their spouses for their own, personal needs. Dusuki (2008) argues that adverse selection and moral hazard can be minimized through enhancing capacity building and lending. Grameen Bank, a conventional MFI, uses a group lending mechanism as an approach to minimize the possibility of asymmetric information, with clients signing financial transactions as a group (Stiglitz 1990).

\subsubsection{Islamic Microfinance AND its Effect on Poverty AlleViation}

Khandker, Samad, and Khan (1998) quantified the village-level impact of three financial institutions, namely Grameen Bank, Bangladesh Rural Advancement Committee (BRACC), and Bangladesh Rural Development Board's (BRDB) RD-12. Their findings revealed the positive impacts of these institutions on income, production, and employment. In our three research sites, microfinance appeared to have a similar effect, with institutions significantly impacting family welfare as the result of business development; Islamic microfinance more so than conventional microfinance.

As we hypothesized, both Islamic and conventional MFIs had a positive effect on poverty alleviation, as indicated by the development of their clients' businesses and consequently their welfare. However, the Islamic MFIs showed a more positive effect than the conventional MFIs, 95.56\% to $67.76 \%$. This disparity between the two types indicates that the Islamic MFIs' greater scheme variation and vested interest in the success of their clients' businesses had a greater 
influence than the conventional MFIs' system of targeting clients with the lowest risk, as well as, possibly, greater benefits.

Furthermore, we hypothesized that profit and loss sharing system (PLS) as the main scheme of Islamic MFI has positive role to support poverty reduction in our research area, however in practice, it did not work well due to lack accountancy of clients and limited knowledge of officials of the institutions.

Widiyanto and Ghafar's (2010) results on the effects of Islamic microfinance on business performance in Indonesia concurred with our own results. They found that the selection process of microenterprises, business control, incentive systems, and maintaining good relationships with clients were the important factors in increasing the effectiveness of their financing. Based on our analyses, we believe that the screening system used by the Islamic MFIs, in particular their targeting of clients who were less inclined to use their funds for unrelated uses, had a significant impact on the development of their clients' businesses. A significant majority of the key informants (90.91\%) in our in-depth interviews stated that Islamic microfinance reduces the poverty level of clients. Widiyanto, Mutamimah, and Hendar (2011), and Smolo and Ghafar (2011), who conducted studies in central Java and Malaysia, respectively, revealed the effectiveness of Islamic MFIs in empowering the needy, although the institutions still had the potential to do more. In our own findings, seven (31.82\%) of our expert respondents recommended that Islamic MFIs provide their financial services to a wider range of communities and collaborate with all related financial agencies. This percentage suggests that the Islamic MFIs_ or at least some of them—did not provide their services to enough people within each region, limiting their outreach. The Islamic MFIs also had limited collaboration with other financial agencies (including cooperative offices). Five respondents (22.73\%) said that the Islamic MFIs should provide fair financing schemes and abolish collateral. Since the profitsharing system was problematic for both institution and client, the Islamic MFIs' clients were required to provide collateral upon being approved for financing.

Hossain (2012) found that MFIs have a positive impact on their clients after joining the institution, with improvements including those to family expenditure and employment creation. The impact on savings and house renovations, however, was less significant. In cases in Malaysia, Bolivia, and Bangladesh, microfinance was found to be an effective tool for increasing income, assets, and spending (Hossain 2012; Chana and Mazanah 2011; Mosley 2001). Similarly, our findings revealed that MFIs positively impacted the welfare of clients, and consequently their poverty. Microfinance is a powerful poverty alleviation tool, enabling the 
poor to increase their economic security; build assets and reduce vulnerability; create demand for goods and services that would otherwise receive little attention; improve nutrition, health care, and education; and stimulate their local economy (Bansal 2012; Rahman, Rafiq, and Momen 2009; Brandsma and Burjorjee 2004, 7). Some welfare indicators in our study were household consumption, health care, education and information access, and empowerment. Our findings showed that both Islamic and conventional MFIs contributed to improvements in consumption, with Islamic MFIs having a somewhat greater impact than conventional MFIs, 93.33\% to 75.56\%. Regarding health care improvement—as indicated by the ability to keep oneself and their family free of disease, to purchase medicine, and maintain good environmental hygienerespondents of both institution types reported an improvement in health care, with the Islamic MFI group have a higher percentage than the conventional MFI group, $92.22 \%$ to $75.56 \%$. In addition, $91.13 \%$ of Islamic MFI clients saw improvements in their education and information access after receiving financing or loans from their institution, compared with $75.53 \%$ of the conventional MFI clients. As another welfare indicator, empowerment improvement includes improved social cohesion and job opportunities, along with greater freedom to express one's opinion or do what one wants. A higher percentage of Islamic MFI clients (85.56\%) than conventional MFI clients (67.78\%) also reported an improvement to their empowerment. We believe that the higher number of assistance programs and training, along with the willingness to involve their officials in clients' personal matters, is the likely reason for the Islamic MFIs' greater success compared with the conventional MFIs.

In general, our study revealed the positive impacts of both Islamic and conventional MFIs on their clients' welfare, with improvements to consumption, health care, education and information access, and empowerment. However, Coleman (1999), in an empirical study in Northeast Thailand, found that group lending-based microfinance had an insignificant impact on physical assets, savings, production, sales, productive expenses and labor time, education, and health care. Takahashi, Higashikata, and Tsukada (2010) conducted an empirical study in Indonesia on the impact of microcredit schemes on the welfare of the poor, and found that microcredit had a statistically insignificant effect on various household outcomes, with the exceptions being sales in non-farm enterprises for the non-poor and schooling expenditures. Amin, Rai, and Topa's (2003) empirical study in Bangladesh found that MFIs were successful in reaching the poor, but less able to reach the vulnerable. Several factors, such as moral hazard, adverse selection, and the poverty level of clients, might affect the MFIs' impacts on welfare. 
In addition, our comparative analysis showed that Islamic microfinance had a greater impact on poverty alleviation than conventional microfinance. Our findings are also in line with those of the United Nations Development Program's (2012) study on scaling up Islamic microfinance in Bangladesh through the private sector, which concluded that Islamic MFIs made positive contributions to poverty alleviation, although these contributions were suboptimal, as the institutions failed to make full use of their financial capabilities. Several factors, such as the interest-free financing options and more flexible repayment plans might be the causes of the Islamic MFIs' greater success in alleviating poverty. Islamic MFIs were able to reach a higher number of poor individuals than conventional MFIs, since these institutions provided qard al hasan, a loan intended for more disadvantaged borrowers. Most Islamic microfinance institutions integrated their financial instruments with various forms of social charity, such as zakat, infaq, and shadaqah, which were then redistributed through qard al hasan schemes (Mirghani 2011). Our results also agree with the conclusions of Bhuiyan et al. (2011) that interest-free loan schemes are powerful tools to eradicate poverty.

Furthermore, Saad (2012) found that the murabahah, musharakah, mudarabah, muzaraah, ijarah, and qard al hasan principles were applicable schemes to finance different economic activities of clients of Amanah Ikhtiar Malaysia (AIM). Our study also revealed that shirkah musharaka, shirkah mudharabah mutlaqah, shirkah mudharabah, qard al hasan, and ba'i bi tsaman 'ajil were the Islamic MFIs' most adopted schemes. However, profit and loss sharing (partnership schemes), which is a core part of Islamic finance, had limited adoption, with both the Islamic MFIs and their clients having limited knowledge of the concept and thus being less receptive of it. A similar lack of knowledge on the part of financial officers in selection, evaluation, and profit management was the cause of the failure of a profit and loss sharing scheme in Sudan (Ahmed 2008).

In our study, although the conventional MFIs' goals were also to empower the poor, they had too limited a number of schemes and sources of funds to significantly impact poverty alleviation. Usually basing their financial services on interest, they presumably did not have a stake in the success of a client's business, since repayment occurred regardless of the result of a loan. Mawa (2008) notes that while some problems still exist, microfinance is able to make meaningful contributions to poverty alleviation, and institutions need to look more seriously at the diversified needs of the poor and target the extremely poor.

Our findings revealed that Islamic MFIs have a greater impact than conventional MFIs on poverty alleviation, with factors such as installment flexibility, more fund sources, and the 
prevalence of soft loans being the likely causes. These findings will affect the already positive demand for Islamic microfinance, especially when conventional MFI clients learn of Islamic MFIs' financing policies and how they may affect them. According to Haque et al. (2011), Muslim respondents are motivated to apply for conventional MFIs' services when there were no

Islamic MFIs within their area. This shows that there is a demand for microfinance, regardless of type, although our results indicate that if they are present, Islamic MFIs will see a greater number of applicants than conventional MFIs.

\subsubsection{ISLAMIC MicrofinANCE AND ITS EFFECT ON ENVIRONMENTAL AWARENESS}

\subsubsection{Training and Social Programs Provided by the MFIs}

In Bangladesh, Grameen Bank had a positive role not only in poverty alleviation, but also the improvement of drinking water and sanitation, as well as the environment and biodiversity (Rouf 2012a). Wenner, Wright, and Lal (2004) additionally found MFIs to have the capabilities to encourage environmental awareness and eco-friendly business practices amongst their clients. However, in our study, this was largely not the case, as only a minority of our respondents reported that their institution provided social programs; $21.11 \%$ of the Islamic MFI clients and $10 \%$ of the conventional MFI clients, indicating that both types had a limited number of environmentally-oriented social programs available for their clients. Hence, MFIs were enablers in their clients' negative impacts on the environment, such as the air pollution caused by brickmaking, waste accumulation and unsustainable logging practices in the furniture processing industry, soil pollution caused by chemical overuse, coastal ecosystem loss from unsustainable fishing, and habitat loss for a large number of flora and fauna because of land and mangrove conversion. Our study suggests a need to increase the scale of environmentally-oriented social and training programs, amongst both types of institution. There are two possible solutions to maximise the ability of MFIs to reduce poverty and increase environmental awareness (Wenner, Wright, and Lal 2004). The first is through providing a course on increasing environmental awareness and promoting voluntary compliance instead of enforcement. The second option is through using simplified environmental assessment tools to identify and mitigate the negative impacts of clients' businesses. Jha and Bawa (2007) additionally argue that skills reduce environmental pressure and that MFIs need to develop knowledge-intensive skills in their clients, as well as increase their own involvement in their business operations.

Our analyses also showed that the majority of clients of Islamic and conventional MFIs reported having no difficulties in maintaining the environment, contrary to what our direct observations 
revealed, with illegal logging and land conversion for tambak ikan, and environmental pollution near water sources and in farmland. This contradiction may be the result of a disconnect between environmental awareness and both competence and responsibility. That such a high percentage of people felt at ease with their own competence in maintaining the environment in the face of considerable degradation may be caused by what we observed to be beliefs that reducing largescale environmental damage was not their responsibility, but that of village officials, as well as a lack of environmental awareness and knowledge. On the other hand, those who reported having difficulties may have had higher awareness of the reality of their surrounding environment, even if they also felt combating pollution was beyond their abilities and thus the responsibility of local officials. These results may be expected in light of both the conventional and Islamic MFIs' low environmental training support. Increasing the number and intensity of these programs, along with allowing for the natural influences of religious teaching and local culture, may contribute to aligning environmental awareness with commitment to sustainable practice.

Regarding environmental damage response, most clients of both MFI types stated that they would attempt to repair damage. The difference between the two types, however, was in how they would go about repairing the environment. Clients of Islamic MFIs (46.67\%) would prefer to improve the environment's condition with the help of their neighbor(s), while clients of conventional MFIs (50\%) would prefer to reduce the environmental damage themselves. A smaller number, $22.22 \%$ of the Islamic MFI clients and $15.56 \%$ of the conventional MFI clients, stated that they would simply report the damage to their village leaders or organizations. These percentages may be influenced by factors unrelated to environmental awareness, namely the livelihoods of the respondents. In general, conventional MFI clients' occupations prevented them from partaking in many social activities, whereas Islamic MFI clients' occupations had greater flexibility. This allowed for more Islamic MFI clients to simply have the time and social incentive to work together with others to reduce environmental damage, and have the opposite be the case for clients of conventional MFIs.

\subsubsection{Knowledge and Behaviour Changes in MFI Clients on Specific Environmental Issues after Joining MFIs}

Rajendran and Raya (2010) found that microfinance and Self Help Groups (SHG) in India helped create environmental awareness and ensure environmental sustainability. Our analyses revealed that the majority of clients of both Islamic and conventional MFIs reported that they were aware of all the environmental issues in our questionnaire, although Islamic MFI clients accounted for a greater percentage than the conventional MFI clients. This awareness was affected by education, 
knowledge of environmental maintenance, as well as local culture and religious beliefs. Increasing their environmental awareness as a whole would be made possible by the fact that all respondents in general had knowledge of individual environmental issues.

In terms of MFIs' impacts on their clients' knowledge of specific environmental issues, only a very small percentage of clients, of both institution types, reported that their institution had any effect on their awareness, with the lowest impact being on unsustainable fishing. The percentage of conventional MFI clients who felt their institution had an effect, however, was higher than those belonging to Islamic MFIs, on every single issue. With clients of both types having lower awareness of this issue than the others, and MFIs failing to have any impact on their awareness of it, MFIs in general may have struggled to educate their clients on environmental issues whose consequences affected them the most.

In Madagascar, access to microfinance positively affected rice yields in lowland areas and soil fertility soil in upland areas, as well as the agricultural production, poverty, and natural resources of clients (Zeller et al. 2000). We found that, while a consistently lower percentage of clients reported that their MFI had an effect on their awareness of a specific issue, many still reported a change in their behavior as the result of their MFI, suggesting that although MFIs had a minimal impact on awareness, they had greater success in influencing the environmental behaviors of their clients. Reasons for this, on the Islamic microfinance side, may be clients' associations of their MFI with Islamic teachings and law on environmental issues, while conventional MFIs' longer tenure in these regions, as well as the lower flexibility of their loaning schemes, may account for their greater success in promoting environmentally-positive behavior. Clients of conventional MFIs, in particular, had an interest in maintaining certain practices that enabled them to repay their loans. Environmental disasters as the result of their behaviors, such as flooding caused by soil erosion and draining water into rivers, harmed them more than clients of Islamic MFIs, because having their occupations be associated with higher risk resulted in correspondingly higher interest rates.

With the lack of comparative studies on Islamic and conventional MFIs and how they affect environmental awareness, placing our research in a greater context is impossible. Nevertheless, in terms of promoting environmental awareness, both Islamic and conventional MFIs had low impacts, with limited training and social programs enabling the low level of environmental awareness amongst clients. Although most of the Islamic MFI clients said that they did not 
perceive any problems in maintaining the environment, our direct observations revealed little concern for the environment. Waste was commonly found beside rivers and coasts, traditional latrines over rivers presented significant health hazards without social repercussions, and locals would eschew more economically and environmentally favorable agricultural waste recycling practices in favor of simply burning their waste.

Both MFI types placed a heavy emphasis on poverty alleviation and welfare improvement, and both had an impact. Neither placed a similar emphasis on the environment, however. Predictably, the impact on environmental awareness was much lower. Thus, green microfinance- that is, the integration of environmental preservation into the microfinance philosophy-was not successful in our research areas. In addition to the limited training and social programs, Islamic MFIs did not allocate any financing to eco-friendly businesses. Instead, they still focused on providing their financial services to low risk businesses. Because environmentally-friendly businesses were associated with high costs and risk, they were left out, environmentally-friendly business practices we re disincentivized, and environmental degradation was allowed to continue. 


\section{Conclusion and Policy Implications}

\subsection{Conclusion}

While empirical studies on whether Islamic microfinance makes positive contributions to reducing poverty and improving environmental awareness are meaningful to the scientific community, they are challenging because so few have been conducted. Studies on Islamic microfinance's impact on environmental awareness, for example, are nonexistent. The present study was designed to examine the impacts of Islamic microfinance on both poverty alleviation and environmental awareness and the variation in its effects between different geographical conditions, as well as how it compares in these respects with conventional microfinance. In general, we found Islamic microfinance institutions (MFIs) to have had a more significant impact on poverty alleviation than conventional MFIs, but a low effect on awareness of specific environmental issues. Islamic MFIs were also successful in combating poverty regardless of regional differences, but similarly ineffective in contributing to environmental awareness.

\subsubsection{GEOGRAPHICAL COMPARISON OF THE EFFECTS OF ISLAMIC MiCROFINANCE ON Poverty Alleviation AND ENVIronmental AWARENESS}

With similar individual characteristics in general, the MFI clients in the three research areas generated income based on natural resources specific to each region; farming in the lowland area, exploiting marine products in the coastal area, and performing agroforestry in the upland area. MFIs would cater to these differentiated livelihoods by providing financial services specific to the economic needs and occupational demands of each individual area. The people were then able to generate extra income through the MFIs' capital injection in the form of loans and financing.

One of the more significant findings to emerge from this study is that both Islamic and conventional MFIs in all three regions made positive contributions to poverty reduction. An indicator of these positive contributions, business development as the result of receiving financing or credit from an MFI, occurred in all three regions, with clients seeing increases in net profits, income from crops and off-farm activities, farmland area, and capital to spend on durable assets and agricultural inputs. Social assistance provided by Islamic MFIs, including housing renovations for the poorest and aid after disasters, positively affected poverty alleviation in the lowland area. In the upland and coastal areas, there was no effect, because Islamic MFIs did not provide any social assistance in these regions, in addition to the conventional MFIs, which also 
did not provide social assistance in the lowland area. Ways in which the coastal area's MFI clients were affected, therefore, were in the welfares of their families and states of their businesses. Amongst the clients in the upland area, they were able to make use of their financing or loans to balance their expenditures, or use the capital for their businesses.

Although the majority of clients in all three areas managed to develop their business as a result of their MFI's services, more businesses in the lowland and coastal areas were successful in doing so compared with the upland area. Of the MFI clients who saw a positive development in their business, the majority reported this development to have had an impact on their family welfare. However, the lowland area had the lowest percentage of respondents re-investing in their business, examples of which in our study were renting or purchasing additional plots of land for further agricultural production, renting or purchasing extra boats, or acquiring tools to process goods themselves for increased net profits.

The next major finding was that MFIs in all three areas had low impacts on environmental awareness. Our findings were contrary to those of Rouf (2012b), who found that MFIs in Bangladesh and Canada positively affected environmentally-sustainable development. Farmers preferred to burn their crop waste rather than use it for cattle feed or raw materials in paper production, consequently polluting the air. Traditional latrines would be placed over the same rivers that would then be used for bathing and washing. Fish were dried in the vicinity of coastal trash, and traditional chimneys were still used in fish processing, depositing large amounts of smoke into populated areas. And garbage was left on riverbanks and streets and pathways. Of the specific environmental issues (air pollution, water pollution, hazardous chemical waste, organic pollutants, chemical fertilizers, unsustainable fishing, land degradation, environmental regulation, and harmful waste disposal), respondents in all three research areas had the lowest awareness of unsustainable fishing. Along with having the lowest awareness of every issue, the coastal area's respondents had significantly lower awareness of unsustainable fishing than those in the lowland and upland areas. The long-term effects of unsustainable fishing are not only in ecosystem deterioration, but the reduction of available resources. Based on coastal respondents' reports, resource availability was already a problem, and thus unsustainable fishing practices, which were common, presented a significant problem to both the ecosystem and their survivability. That awareness of this environmental issue was lower than every other one suggests a serious regulation and education deficiency on the part of the local government and microfinance institutions. 
Most of the respondents in the lowland, coastal, and upland areas believed that their institutions did not provide social programs or training on specific environmental issues. MFIs in all three areas had problems with providing environmental training and social programs, exasperating an already existing lack of attention on the part of their clients, citing high costs as the main reason for their lack of motivation to allocate a part of their net profits to environmental preservation. The result of this was that low-risk businesses that often polluted the environment were targeted, simply because of their higher potential sustainability, and environmentally-friendly businesses that were considered to be of higher risk and cost were avoided.

\subsubsection{THE EFFEcts of Islamic ANd CONVENTIONAL MicRofinANCE ON POVERTY AlleViation AND ENVIronMENTAL AWARENESS}

The slight differences between clients of Islamic and conventional MFIs had little to no effect on MFI type selection. Most Islamic MFI clients preferred to apply for a savings account or loan from an Islamic MFI, while conventional MFI clients preferred to save their money with an Islamic MFI and apply for loans with relatives or money lenders.

Asymmetric information was found to be a common occurrence when clients failed to abide by their contractual agreements with their institutions. Moral hazard was less prevalent amongst Islamic MFI clients compared with conventional MFI clients. Less monitoring, as well as less strict usage rules, than the Islamic MFIs was the cause of the conventional MFIs' higher prevalence. In addition, some respondents-one of whom was directly observed doing sowould apply with an institution on behalf of a family member or friend, abusing their institution's trust, while others used the funds acquired by their spouses for their own needs.

The most obvious finding to emerge from this study is the positive effects of both Islamic and conventional MFIs on poverty alleviation, in agreement with a number of other studies in Malaysia, Bolivia, and Bangladesh (Hossain 2012; Chana and Mazanah 2011; Mosley 2001). However, Islamic microfinance was found to be more successful than conventional microfinance at combating poverty, in accord with the conclusions of the United Nations Development Program (2012). Some causal factors were interest-free financing options and more flexible repayment plans compared with those of the conventional MFIs. Furthermore, Islamic MFIs were able to reach a higher number of individuals than conventional MFIs, because of their more diverse and lucrative fund sources, one of which was public donations that were then redistributed to the poorest as qard al hasan (credit without interest). Although the conventional MFIs' goals were also to empower the poor, this limitation in number of schemes and fund 
sources forced them to use interest as a means of sustainability, significantly affecting their ability to impact poverty alleviation.

While microfinance had a positive effect on poverty alleviation, the opposite was true of its effect on environmental awareness. Waste was commonly found beside rivers and coasts, as well as traditional latrines over rivers, and locals would burn agricultural waste as opposed to recycling or re-using it. On the part of the MFIs, they were found to provide only a limited number of environmental-oriented social programs. Nevertheless, the majority of MFI clients were aware of every specific issue, with a greater percentage belonging to Islamic MFIs than conventional MFIs. Increasing their environmental awareness as a whole, therefore, would be possible because this awareness signifies a willingness to improve both awareness and behavior. Further indicating the low effect of microfinance, however, was the fact that only a very small percentage of clients of both institutions stated that their institution had an impact on their awareness of those issues, with conventional MFIs this time having a greater influence on client awareness than Islamic MFIs. External actors, such as local governmental organizations and regulatory bodies, as well as local culture and beliefs, therefore had a greater impact on environmental awareness than MFIs.

Overall, while both MFI types had an impact, Islamic MFIs, in particular, affected the welfare of their clients, as shown in their improvements in consumption, education, and health care. However, the fact that Islamic MFIs did not allocate any financing towards eco-friendly businesses and had limited programs on environmental issues contributed to their inability to impact their clients' environmental awareness and behavior. Hence, green microfinance, having a greater focus on environmental preservation in microfinance, was not successful in our research areas. The Islamic MFIs still focused on providing their financial services to low-risk businesses, whose impacts on the environment were not considered. While the result for Islamic MFIs was positive, the long-term environmental effects are, at best, unknown. At worst, however, continued environmental degradation will result in further resource scarcity, and, consequently, increased poverty. Green microfinance, as a result, is imperative in a financial landscape dictated by natural resources. Green Islamic microfinance is a logical next step in the development of Islamic finance, as institutions attempt to empower the people and communities inhabiting ecosystems that become increasingly fragile. Further research is needed on the efficacy and challenges of this next step. 


\subsection{Policy Implications}

The findings of this study may have several important implications for policy- and decisionmakers, non-governmental organizations, institutions, and researchers.

The MFIs in the three different areas provided financial services geared towards meeting the demands of the local communities. The people in the lowland area were able to buy seeds and fertilizer as a result of access to microfinance; the people in the coastal area could fish or process and grill fish; while the inhabitants of the upland area were able to produce cassava chips, make clay bricks, or grow kapok and sengon trees. These results suggest that decision-makers should be aware of the positive role MFIs play in helping the poor start new businesses or sustain existing ones, and enact regulatory and financial policies that support this positive role.

The establishment of pondok pesantren positively contributed to the development of Islamic MFIs. Their social services, which form part of their educational activities and include teaching and training on proper business conduct, affected the positive perceptions of Islamic MFIs. Most community leaders graduated from this Islamic educational system and were able to educate locals on Islamic law-compliant business practices, such as conducting fair transactions, avoiding moral hazards, and refraining from cheating, as well as abolishing interest in cases where credit is involved. In the lowland and upland areas, furthermore, the majority of Islamic MFIs' clients were graduates of pondok pesantren. The evidence from this study thus suggests that Islamic MFIs and their stakeholders should collaborate with pondok pesantren and their graduates in order to better target prospective clients whose business practices comply with Islamic law.

The results of this study revealed that MFIs increased their clients' families' welfare and household expenditures. In all three research sites, the majority of respondents were able to develop their business as a result of receiving financing or loans, although the upland area had slightly lower effects than the two other areas. This suggests that rather than a broad approach, governmental policies should focus on the needs of individual regions. As such, while the upland area needs greater infrastructure support, the lowland area needs greater economic development and investment, in order mitigate the lower business re-investment from MFI clients, through the provision of additional land or development of the land market (Lerman 2008), provision of more intense agricultural subsidies and educational programs, and reduction of foreign imports—such as rice—-that are available domestically. 
In terms of increasing environmental awareness, MFIs in all three research sites were found to be lacking. Most of the microfinance institutions in all sites had problems with providing environmental training and social programs to their clients, reportedly finding these programs to be more costly than they were worth. Thus, the environmental awareness of the communities within the three areas as a whole was relatively unchanged by the presence of MFIs. There is the possibility that policy- and decision-makers can contribute to environmental sustainability simply by incentivizing and collaborating with MFIs to provide environmental programs on a larger scale. Our results also support the idea that, in spite of the perception of higher risk, by promoting environmentally-friendly business practices through the allocation of credit schemes to businesses that emphasize these practices, MFIs themselves will benefit by minimizing lending risks because of environmental and occupational safety hazards.

Asymmetric information frequently occurred in our study when clients violated their contracts with their institutions, failed to use their acquired funds for productive purposes, or applied on behalf of others who had difficulties getting approved. With the conventional MFIs having greater incidences of moral hazard than the Islamic MFIs, these institutions should establish more strict usage rules before approving a loan. Both Islamic and conventional MFIs should enhance monitoring, capacity building, and social cohesion to eliminate adverse selection and moral hazard. In addition, ba'i bi tsaman 'ajil, the Islamic MFIs' most adopted scheme is not in accord with Islamic law in practice, since the institutions supplied money instead of goods, enabling moral hazards. Thus, Islamic institutions should be made aware of financing schemes that are compliant with Islamic law, and promote the self-regulation of institutions to prevent practices that are not in the best interests of clients.

Both Islamic and conventional MFIs helped alleviate poverty by helping clients develop their businesses. However, Islamic MFIs were more successful, aided by their greater scheme variation, interest-free financing options, higher number of assistance programs, and more flexible repayment plans. Their success was also aided by their provision of qard al hasan. Taken together, these results suggest that MFIs and their stakeholders should integrate the government's poverty alleviation program together with the central government as a means of reducing poverty. The government may also find greater value in its poverty reduction policies by investing in Islamic MFIs with the specific intention of providing qard al hasan schemes to a greater number of poor-and especially poorest-people.

Because of their lack of sufficient environmentally-oriented social programs, both Islamic and 
conventional MFIs had a low impact on environmental awareness. Thus, they were enablers in their clients' negative impacts on the environment. Both types of microfinance institution should increase the scale of their environmentally-oriented social and training programs. Islamic MFIs, in particular, should invest part of their social fund sources (zakat, infaq, and shadaqah) in ecofriendly business practices. There is, therefore, an additional need for collaboration between the local and central government, as well as NGOs and MFIs to accelerate the process of increasing environmental awareness. The government should use the MFIs as a proxy by providing them with incentives to target clients with environmentally-friendly businesses, as well as creating environmental assessment tools that are able to identify and mitigate the negative impacts of clients’ businesses (Wenner, Wright, and Lal 2004).

One limitation of this study is the lack of empirical research into the role of Islamic microfinance in poverty alleviation. Additionally, no research was found concerning the impact of Islamic microfinance on environmental awareness. Comprehensive comparisons with previous empirical research, therefore was impossible, and more so on environmental issues. This is the first empirical study of which we know dedicated to the role of Islamic microfinance in both poverty alleviation and environmental awareness. Thus, further research expanding upon our results will prove meaningful. More specifically, further elaboration and investigation into the exact reason for the coastal area's low awareness of an environmental issue affecting it the most may provide insight not only into this region, but the dynamics of environmental awareness in resourcelimited, high-poverty communities. In addition, although profit and loss sharing was the main instrument of the Islamic MFIs' financial contracts, it was largely unsuccessful in our research sites because of institutions and clients' lack of familiarity with it. Further empirical research should establish whether profit and loss sharing is the best system in Islamic finance to empower the poor and combat poverty. Most importantly, however, further research is needed on how best to both empower the poor and improve the environment in which they live. While green microfinance was not successful in our research areas, it continues to be the best method of reducing poverty whilst contributing to environmental sustainability. With Islamic MFIs finding themselves operating in environments that are increasingly vulnerable to human activities, they need to consider shifting focus from low-risk businesses to environmentally-friendly ones. Thus, green Islamic microfinance may be the next step in the development of Islamic finance. 


\section{REFERENCES}

Adams, Dale W., and J.D. Von Pischke. 1992. "Microenterprise Credit Programs: Déjà Vu.” World Development 20 (10): 1463-1470.

ADB (Asian Development Bank). 2000. Finance for the Poor: Microfinance Development Strategy. Mandaluyong City: Asian Development Bank.

Afrane, Sam. 2002. "Impact Assessment of Microfinance Intervention in Ghana and South Africa." Journal of Microfinance 4 (1): 37-58.

Ahlin, Christian, Jocelyn Lin, and Michael Maio. 2011. "Where does Microfinance flourish? Microfinance Institution Performance in Macroeconomic Context.” Journal of Development Economics 95: 105-120.

Ahmed, Gaffar Abdalla. 2008. "The Implication of Using Profit and Loss Sharing Modes of Finance in the Banking System, with a Particular Reference to Equity Participation (partnership) Method in Sudan.” Humanomics 24 (3): 182-206.

Ahmed, Habib. 2002. "Financing Microenterprises: "An Analytical Study of Islamic Microfinance Instritutions.” Islamic Economic Studies 9 (2): 27-64.

. 2007. “Waqf-based Microfinance: Realizing the Social Role of Islamic Finance.” Paper presented at the International Seminar on Integrating Awqaf in the Islamic Financial Sector, Singapore, March 6-7, 2007. http://imfn.org/images/Litrature/WaqfBased\%20Microfinance\%20Realizing\%20The\%20Social\%20Role\%20Of\%20Islamic.p $\mathrm{df}$

Ahmed, Nesar, Sanzidur Rahman, Stuart W. Bunting, and Cecile Brugere. 2013. "SocioEconomic and Ecological Challenges of Small-Scale Fishing and Strategies for its Sustainable Management: A Case Study of the Old Brahmaputra River, Bangladesh.” Singapore Journal of Tropical Geography 34: 86-102.

Akca, H., M. Sayili, and M. Yilmazcoban. 2007. "Rural Awareness of Environmental Issues: the Case of Turkey.” Polish Journal of Environmental Studies 16 (2): 177-182.

Akerlof, George A. 1970. "The market for "Lemons": Quality Uncertainty and the market Mechanism.” Quarterly Journal of Economics 84: 488-500. http://qje.oxfordjournals.org.

Allet, Marion. 2012. "Mitigating environmental risks in small scale activities: what role for microfinance? A case study from El Salvador.” CEB Working paper 12/021: 1-26. https://www.dipot.ulb.ac.be/dspace/bitstream/2013/123289/1/wp12021.pdf.

Allet, Marion, and Marek Hudon. 2013. "Green Microfinance: Characteristics of Microfinance Institutions Involved in Environmental Management.” CEB Working Paper 13 (005): 135 .

Al-Mamun, Abdullah, C.A Malarvizhi, Sayed Hossain, and Siow-Hooi Tan. 2012. "Examining the Effect of Microcredit on Poverty in Malaysia.” ASEAN Economic Bulletin 29 (1): 15-28.

Amin, Sajeda, Ashok S. Rai, and Giorgio Topa. 2003. "Does Microcredit Reach the Poor and Vulnerable? Evidence from Northern Bangladesh.” Journal of Development Economics 70: 59-82. 
Anderson, C. Leigh, Laura Locker, and Rachel Nugent. 2002. "Microcredit, Social Capital, and Common Pool Resources.” World Development 30 (1): 95-105.

Arafat, Hasan A, Issam A. Al-Khatib, Raeda Daoud, and Hadeel Shwahneh. 2007. "Influence of Socio factors on Street Litter Generation in the Middle East: effect of Education Level, Age, and Type of Residence.” Waste Management and Research 25: 363-370.

Archer, Geoffrey R. 2009. "Exploring Green Microfinance: An Analysis of Environmental Protection Language in Microfinance Lending Criteria.” doi: 10.2139/ssrn.1437103.

Armendariz de Aghion, Beatriz, and Jonathan Morduch. 2000. "Microfinance beyond Ground Lending.” Economics of Transition 8 (2): 401-420.

2005. The Economics of Microfinance. Cambridge, Massachusetts: The MIT Press.

Armitage, D. 2002. "Socio-institutional dynamics and the political ecology of mangrove forest conservation in Central Sulawesi, Indonesia.” Journal of Global Environmental Change 12: 203-217.

Babandi, Gumel Gambo. 2011. "Microfinance Institutions in Nigeria Outreach and Sustainability: Questionnaire Survey Findings.” International Journal of Business and Social Science 2 (9): 126-129.

Bakhtiari, Sadegh. 2009. "Islamic Microfinance, Providing Credit to the Poor: A Case Study of Iran.” International Economic Studies 34 (1): 99-107.

Bank Indonesia. 2003. "Peraturan Bank Indonesia No. 5/18/PBI/2003 Tentang Pemberian Bantuan Teknis dalam Rangka Pengembangan Usaha Mikro dan Kecil.” Bank Indonesia. http://www.bi.go.id/biweb/utama/peraturan/pbi-5-18-03.pdf.

—. 2011. Outlook Perbankan Syariah 2012. http://www.bi.go.id/NR/rdonlyres /BA0429EA-EF4E-4ADB-B32A-E6A83B1C4505/25052/outlook_perbankan_syariah_ 2012.pdf

Bansal, Atul. 2012. "Finance for the Poor: From Microcredit to Micro financial Services in India.” Asian Journal of Research in Banking and Finance 2 (1): 16-27.

BAPPEDA (Badan Perencanaan Pembangunan Daerah) and BPS (Badan Pusat Statistik). 2010. Produk Domistik Regional Bruto Kabupaten Pasuruan Taun 2009 (Gross Regional Domestic Products of Pasuruan Regency 2009). Pasuruan: Badan Pusat Statistik Kabupaten Pasuruan.

Barden, Kenneth E. 2010. "Both a Borrower and Lender Be Can Islamic Microfinance Bring Peace to Palestine?” World Policy Journal 27 (1): 97-102.

Becker, Phillip M. 2010. Investing in Microfinance; Integrating New Asset Classes into an Asset Allocation Framework Applying Scenario Methodology. Springer Fachmedien Wiesbaden GmbH, Germany.

Berger, Marguerite, Lara Goldmark, and Tomas Miller-Sanabria, eds. 2006. An Inside View of Latin America Microfinance. Washington, D.C.: Inter-American Development Bank.

Berhane, Guus, and Cornelis Gardebroek. 2011. "Does Microfinance Reduce Rural Poverty? Evidence Based on Housing Panel data from Northern Ethiopia.” American Journal of Agricultural Economics 93 (1): 43-55. 
Besley, Timothy, and Stephan Coate. 1995. "Group Lending, Repayment Incentives and Social Collateral.” Journal of Development Economics 46: 1-18.

Bester, Helmut. 1987. "The Role of Collateral in Credit market with Imperfect Information." European Economic Review 31: 887-899.

Bhuiyan, Abu Bashar, Chamhuri Siwar, Abdul Ghafar Ismail, and Basri Talib. 2011. "Islamic Microcredit is the way of Alternative Approach for Eradicating Poverty in Bangladesh: A Review of Islamic Bank Microcredit.” Australian Journal of basic Applied Sciences 5 (5): 221-230.

BPS (Badan Pusat Statistik) Kabupaten Pasuruan (Pasuruan Regency's Center of Statistics). 2010. Kabupaten Pasuruan Dalam Angka 2010 (Pasuruan Regency in Figures 2010) Pasuruan: Badan Pusat Statistik Kabupaten Pasuruan.

—. 2011. Kraton Dalam Angka 2010 (Kraton In Figures 2010). Pasuruan: Badan Pusat Statistik Kabupaten Pasuruan.

2011. Nguling Dalam Angka 2010 (Nguling In Figures 2010). Pasuruan: Badan Pusat Statistik Kabupaten Pasuruan.

. 2011. Purwosari Dalam Angka 2010 (Purwosari In Figures 2010). Pasuruan: Badan Pusat Statistik Kabupaten Pasuruan.

BPS (Badan Pusat Statistik) and BAPPEDA (Badan Perencanaan Pembangunan Daerah). 2010. Updating Data Base Kabupaten Pasuruan 2009. Pasuruan: Badan Pusat Statistik Kabupaten Pasuruan and Badan Perencanaan Pembangunan Daerah.

Brandsma, Judith, and Deena Burjorjee. 2004. Microfinance in the Arab States: Building Inclusive Financial Sectors. New York: United Nations Capital Development Fund.

Brook, Robert M., Karen J. Hillyer, and G. Bhuvaneshwari. 2008. "Microfinance for Community Development, Poverty Alleviation, and Natural Resources Management in Peri-Urban Hubli-Dharwad, India." Environment and Urbanization 20: 149-163. doi: $10.1177 / 0956247808089153$.

Brown, Philip H., and Albert Park. 2002. "Education and poverty in rural China.” Economics of Education Review 21 (6): 523-541.

Cavendish, William. 2000. "Empirical Regularities in the Poverty-Environment Relationship of Rural Households: Evidence from Zimbabwe.” World Development 28 (11): 1979-2003.

CGAP (Consultative Group to Assist the Poor). 2003. Microfinance Poverty Assessment Tool. Washington, D.C.: The World Bank.

- 2004. Key Principle of Microfinance. Washington, D.C.: The World Bank. http://www.cgap.org/sites/default/files/CGAP-Consensus-Guidelines-Key-Principles-ofMicrofinance-Jan-2004.pdf.

2006. Good Practice Guidelines for Funders of Microfinance. Washington, D.C.: The World Bank.

Chana, Sow H., and Mazanah Abdul Ghani. 2011. "The Impact of Microloans in Vulnerable Remote Areas: Evidence from Malaysia.” Asia pacific Business Review 17 (1): 45-66.

Coleman, Brett E. 1999. “The Impact of Group Lending in Northeast Thailand.” Journal of Development Economics 60: 105-141. 
Copestake, James, Sonia Bhalotra, and Susan Johnson. 2001. "Assessing the Impact of Microcredit: A Zambian Case Study.” Journal of Development Studies 37 (4): 81-100.

Crawford, B. 2007. Assessment of the Microfinance Initiatives of the Post-Tsunami Sustainable Coastal Livelihoods Program, Thailand. The Post-Tsunami Sustainable Coastal Livelihoods Program in association with The Sustainable Coastal Communities and Ecosystems Program (SUCCESS). Coastal Resources Center, University of Rhode Island. http://pdf.usaid.gov/pdf_docs/PNADN445.pdf.

Daly, Anne, and George Fane. 2002. "Anti-Poverty Programs in Indonesia.” Bulletin of Indonesia Economic Studies 38 (3): 309-329.

Dasgupta, Partha, and Karl-Göran Mäler, eds. 2003. The Environment and Emerging Development Issues. Vol. 1. Oxford: Oxford University Press.

De Kadt, Emanuel. 2009. “Should God Play a Role in Development?” Journal of International Development 21: 781-786. doi: 10.1002/jid.1617.

Deloach, Stephen B., and Erika Lamanna. 2011. "Measuring the Impact of Microfiannce on Child Health Outcome in Indonesia.” World Development 39 (10): 1808-1819.

Denzin, Norman K. 1971. “The Logic of Naturalistic Inquiry.” Social Forces 50 (2): 166-182.

Dusuki, Asyraf Wajdi. 2008. "Banking for the Poor: The Role of Islamic Banking in Microfinance initiatives.” Humanomics 24 (1): 49-66.

Effendi, Jaenal, and Ernawati. 2005. Profil Organisasi Santri. Jakarta: Fajar Gemilang.

Fairbourne, Jason S. 2006. "Micro franchising: A New Tool for Creating Economic SelfReliance.” Journal of Microfinance 8 (1): 18-23.

Farell K, M. Kratzman, S. McWilliam, N. Robinson, S. Saunders, J. Ticknor, and K. White. 2002. "Evaluation Made Very Easy, Accessible, and Logical." Atlantic Centre of Excellence for Women's Health, Halifax, Nova Scotia.

Fernandes, Marcelo. 2009. Statistics for Business and Economics. Holstebro: Ventus Publishing ApS.

Fernando, Nimal A. 2007. Low-Income Households' Access to Financial Services, International Experience, Measure for Improvement, and the Future. Mandaluyong City: Asian Development Bank.

Friedman, Andrew L., Samantha Miles, and Cameron Adams. 2000. "Small and medium-sized enterprises and the environment: Evaluation of a specific initiative aimed at all small and medium-sized enterprises.” Journal of Small Business and Enterprise 7 (4): 325342.

Gadenne, David L., Jessica Kennedy, and Catherine McKeiver. 2009. "An Empirical Study of Environmental Awareness and Practices in SMEs.” Journal of Business Ethics 84: 4563.

Gait, Alsadek H., and Andrew C. Worthington. 2009. "A Primer on Islamic Finance: Definitions, Sources, Principles, and Methods.” Discussion Paper Finance 2009 (09). Griffith Business School.

Gillham, Bill. 2000. Case Study Research Methods. Beccles: Paston PrePress. 
Golafshani, Nahid, 2003, “Understanding Reliability and Validity in Quantitative Research.” The Qualitative Report 8 (4): 597-607.

Goldberg, Mike, and Eric Palladini. 2010. Managing Risk and Creating Value with Microfinance. Washington, D.C.: The World Bank.

Goodman, Patrick. 2006. "Microfinance Investment Funds: Objectives, Players, Potential.” In Microfinance Investment Funds: Leveraging Private Capital for Economic Growth and Poverty Reduction, edited by Ingrid Matthäus-Maier and J.D von Pischke, 11-45. Berlin: Springer.

Governor of East Java. 2013. Governor's Regulations on Minimum Wage 72 (2012). http://www.pasuruankab.go.id/mod/download/dokumen/pergub\%20jawa\%20timur\%20n omor\%2072\%20tahun\%202012.pdf.

Hamada, Miki. 2010. "Financial Services to the Poor: an Introduction to the Special Issue on Microfinance.” The Developing Economies 48 (1): 1-14.

Hasan, Zubair. 1995. "Economic Development in Islamic Perspective: Concept, Objectives, and Some Issues.” Journal of Islamic Economics 1 (6): 80-111.

Haque, Muhammad Sayeedul, and Masahiro Yamao. 2011. "Prospect and Challenge of Islamic Microfinance Programs: A Case Study in Bangladesh.” International Journal of Economic Policy in Emerging Economies 4 (1): 95-111.

Hermes, Niels, and Robert Lensink. 2011. "Microfinance, Outreach, and Sustainability.” World Development 39 (6): 875-881.

Hill, Hal. 2001. "Small and Medium enterprises in Indonesia: Old Policy Challenges for a New Administration.” Asian Survey 41 (2): 248-270.

Hillary, Ruth. 2004. "Environmental management systems and the smaller enterprise.” Journal of Cleaner Production 12: 561-569.

Hossain, Mohammad Kamal. 2012. "Measuring the Impact of BRAC Microfinance Operations: A Case Study of a Village.” International Business Research 5 (4): 112-123.

Hulme, David. 2000. "Is Microdebt Good for Poor People? A Note on the Dark Side of Microfinance.” Small Enterprises Development 11 (1): 26-28.

Hulme, David, and Thankom Arun, eds. 2009. Microfinance: A Reader. New York: Routledge.

Imai, Katsushi, and Md. Shafiul Azam. 2010. "Does Microfinance Reduce Poverty in Bangladesh? New Evidence from Household Panel Data.” Economics Discussion Paper Series EDP-0809. University of Manchester, Economics School of Social Sciences.

Indonesian Banking Statistics. 2012. Central Bank of Indonesia, Monthly 11 (1): 129. http://www.bi.go.id/NR/rdonlyres/DE6BC848-79BB-4F5C-8DA2-63AD1F492365 /28085/SPI_1212.pdf.

Jackson C. Kirabo, and Henry S. Schneider. 2011. "Do Social Connections Reduce Moral Hazard? Evidence from the New York City Taxi Industry." American Economic Journal: Applied Economics 3 (3): 244-267. doi: 10.1257/app.3.3.244.

Jegede, Charles A., James Kehinde, and Babatunde Hamed Akinlabi. 2011. "Impact of Microfinance on Poverty Alleviation in Nigeria: An empirical Investigation.” European Journal of Humanities and Social Sciences 2 (1): 97-111. 
Jellinek, Lea. 1992. “Indonesia: Strategy for a Sustained Reduction in Poverty.” Journal of Southeast Asian Studies 23 (2) 465-469 doi:10.1017/S0022463400006470.

Jha, S., and K.S. Bawa. 2006. "The Economics and Environmental Outcomes of Microfinance Projects: an Indian Case Study.” Environment, Development and Sustainability 9: 229239.

Julian, David A. 1997. "The Utilization of the logic Model as a system level Planning and Evaluation Device.” Evaluation and Program Planning 20 (3): 251-257.

Kaleem, Ahmad, and Saima Ahmed. 2010. “The Qur'an and Poverty Alleviation: A Theoretical Model for Charity-Based Islamic Microfinance Institutions.” Nonprofit and Voluntary Sector Quarterly 39 (3): 409-428.

Karlan, Dean, and Jonathan Zinman. 2009. "Observing Un-observables: Identifying Information Asymmetries with a Consumer Credit Field Experiment (Notes and Comments)." Econometrica 77 (6): 1993-2008.

Karim, N., M. Tarazi, and X. Reille. 2008. “Islamic microfinance: An emerging market niche.” Focus Note 49. Washington, D.C.: CGAP.

Kathiresan, K., and N. Rajendran. 2005. "Coastal mangrove forests mitigated tsunami." Estuarine, Coastal and Shelf Science 65: 601-606.

Kaushal, K. K., and J.C. Kala. 2005. "Nurturing Joint Forest Management through Microfinance: a Case from India.” Journal of Microfinance 7 (2): 1-12.

Khalily, M.A. Baqui. 2004. "Quantitative Approach to Impact Analysis of Microfinance Programs in Bangladesh-What Have We Learned?” Journal of International Development 16: 331-353.

Khan, Ajaz Ahmed. 2008. Islamic Microfinance: Theory, Policy, and Practice. Birmingham, United Kingdom: Islamic Relief Worldwide.

Khandker, Shahidur R. 2005. "Microfinance and poverty: Evidence using panel data from Bangladesh.” The World Bank Economic Review 19 (2): 263-286.

Khandker, Shahidur R., and Hussain A. Samad, and Zahed H. Khan. 1998. "Income and Employment Effects of Micro-credit Programs: Village-Level Evidence from Bangladesh.” The Journal of Development Studies 35 (2): 96-124.

Klasen, Stephan. 1997. "Poverty, inequality and deprivation in South Africa: An analysis of the 1993 SALDRU survey.” Social Indicators Research 41 (1/3): 51-94.

La Torre, Mario, and Gianfranco A. Vento. 2006. Microfinance. New York: Palgrave Macmillan.

Laffont, Jean-Jacques. 2003. “Collusion and Group Lending with Adverse Selection.” Journal of Development Economics 70: 329-348.

Lal, Abhishek. 2010. “An Overview of Microfinance and Environmental Management.” The Global Development Research Center. http://www.gdrc.org/icm/environ/abhishek.html.

Lashley, Jonathan G. 2004. "Microfinance and Poverty Alleviation in the Caribbean: A Strategy Overview.” Journal of Microfinance 6 (1): 83-94.

Ledgerwood, Joanna. 1999. Microfinance Handbook: an Institutional and Financial Perspective. Washington, D.C.: The Word Bank. 
Ledgerwood, Joanna and Victoria White. 2006. Transforming Microfinance Institutions: Providing Full Financial Services to the Poor. The World Bank, Washington DC.

Lepoutre, Jan, and Aimé Heene. 2006. "Investigating the Impact of Firm Size on Small Business Social Responsibility: A Critical Review.” Journal of Business Ethics 67: 257-273.

Lerman, Z. 2008. "Agricultural Development in Central Asia: A Survey of Uzbekistan, 20072008.” Eurasian Geography and Economics 49 (4): 481-505.

Lunn, Jenny. 2009. "The Role of Religion, Spirituality, and Faith in Development: a Critical Theory Approach.” Third World Quarterly 30 (5): 937-951.

Maier, Ingrid Matthäus, J.D von Pischke, eds. Goodman Patrick. 2006. Microfinance Investment Funds: Leveraging Private Capital for Economic Growth and Poverty Reduction. Springer Berlin Germany.

Masyita, Dian, and Habib Ahmed. 2011. "Why is Growth of Islamic Microfinance Lower than Conventional? A Comparative Study of the Preferences and Perceptions of the Clients of Islamic and Conventional Microfinance Institutions in Indonesia.” Paper presented at the Eighth International Conference on Islamic Economics and Finance, Doha, Qatar, December 19-21, 2011. http://islam-economy.net/mi_05.pdf

Mathison, Sandra. 1988. "Why Triangulate, Educational Researcher.” Educational Researcher 17 ( 2): 13-17.

Mawa, Bentul. 2008. "Impact of Microfinance: Towards Achieving Poverty Alleviation?” Pakistan Journal of Social Sciences 5 (9): 876-882.

Mazzucato, V., and D. Niemeijer. 2002. "Population Growth and the Environment in Africa: Local Informal Institutions, the Missing Link.” Economic Geography 78 (2): 171-193.

McKeiver, C., and D. Gadenne. 2005. "Environmental Management Systems in Small and Medium Businesses.” International Small Business Journal 23: 513-537.

McKernan, Signe Mary. 2002. "The Impact of Microcredit Programs on Self-employment Profits: Do Non-credit Program Aspects Matter?” The Review of Economic and Statistics 84 (1): 93-115.

McLaughlin, John A., and Gretchen B. Jordan. 1999. "Logic Models: A Tool for Telling Your Program’s Performance Story.” Evaluation and Program Planning 22: 65-72.

Meisami, Hossin, Davood Manzur, and Mehdi Roayaee. 2011. "Islamic vs. Conventional Microfinance: A Comparative Theoretical Analysis.” International Journal of Business and Management Tomorrow 1 (1): 99-105.

Mersland, Roy, Bert D’espallier, and Magne Supphellen. 2013. "The Effect of Religion on Development Effort: Evidence from the Microfinance Industry and a Research Agenda.” World Development 41: 145-156.

Ministry of Cooperative and Small and Medium Enterprises 2012. "Data UMKM." http://www.depkop.go.id/index.php?option=com_phocadownload\&view=sections\&Item id $=93$

Mirghani, Murtada, Mubarak Muhammad, Abul Bashar Bhuiyan, and Chamhuri Siwar. 2011. "Islamic Microcredit and Poverty Alleviation in the Muslim World: Prospects and Challenges.” Australian Journal of Basis and Applied Sciences 5 (9): 620-626. 
Mislan, Cokro, Widiyanto, and Ismail Abdul Ghafar. 2008. "Sustainability of BMT financing for Developing Micro-enterprises.” MPRA Paper 7434: 1-31. http://mpra.ub.unimuenchen.de/7434/1/MPRA_paper_7434.pdf.

Mohammed, Aliyu Dahiru, and Zubair Hasan, 2008. "Microfinance in Nigeria and the Prospects of Introducing its Islamic Version there in the Light of Selected Muslim Countries' Experience.” MPRA paper 8127: 1-18. http://mpra.ub.uni-muenchen .de/8127.

Montgomery, Heather, and John Weiss. 2011. "Can Commercially-Oriented Microfinance Help Meet The Millennium Development Goals? Evidence from Pakistan.” World Development 39 (1): 87-109.

Montgomery, Richard. 1996. "Disciplining or Protecting the Poor? Avoiding the Social Costs of Peer Pressure in Micro-credit Schemes.” Journal of International Development 8 (2): 289-305.

Morduch, Jonathan. 1999. "The Microfinance Promise.” Journal of Economic Literature 37: 1569-1614.

Morris, Gayle, and Carolyn Barnes. 2005. “An Assessment of the Impact of Microfinance.” Journal of Microfinance 7 (1): 39-54.

Mosley, Paul. 2001. "Microfinance and Poverty in Bolivia.” Journal of Development Studies 37 (4): 101-132.

Muryani, C., Ahmad, S. Nugraha, and T. Utami. 2011. "Model Pemberdayaan Masyarakat dalam Pengelolaan dan Pelestarian Hutan Mangrove di Pantai Pasuruan, Jawa Timur" ("The Model of Community Empowerment in the Management and Conservation of Mangrove Forest in the Coastal Pasuruan, East Java”). Manusia dan Lingkungan 18 (2): 75-84.

Navajas, Sergio, Mark Schreiner, Richard L. Meyer, Claudio Gonzales-Vega, and Jorge Rodriguez-Meza. 2000. "Microcredit and the Poorest of the Poor: Theory and Evidence from Bolivia.” World Development 28 (2): 333-346.

Nurkin, B. 1994. "Degradation of mangrove forests in South Sulawesi, Indonesia." Hydrobiologia 285: 271-276.

Obaidullah, Mohammed. 2008. Introduction to Islamic Microfinance. New Delhi: IBF Net.

Obaidullah, Mohammed and Tariqullah Khan. 2008 "Islamic Microfinance Development: Challenges and Initiatives.” Islamic Research \& Training institute Policy Dialogue Paper 2. doi: 10.2139/ssrn.1506073.

Olli, Eero, Gunnar Grendstad, and Dag Wollebaek. 2001. "Correlates of Environmental Behaviors: Bringing Back Social Context.” Environment and Behavior 33 (2): 181-208.

Parvin, Gulsam Ara, and Rajib Shaw. 2013. "Microfinance institutions and a coastal community's disaster risk reduction, response, and recovery process: a case study of Hatiya, Bangladesh.” Disaster 37 (1): 165-184. doi: 10.1111/j.1467-7717.2012 .01292.x.

Petts, Judith. 1998. "Environmental Responsiveness, Individuals and Organizational Learning: SME Experience.” Journal of Environmental Planning and Management 41 (6): 711730. doi:10.1080/09640569811380. 
Prater, Edmund, and Soumen Ghosh. 2005. "Current Operational Practices of U.S. Small and Medium-Sized Enterprises in Europe.” Journal of Small Business Management 43 (2): 155-169.

Quinones, Benjamin R. Jr., and Hans Dieter Seibel. 2000. "Social capital in microfinance: Case studies in the Philippines.” Policy Sciences 33: 421-433.

Rahman, Abdul Rahim Abdul. 2007. "Islamic Microfinance: A Missing Component in Islamic Banking.” Kyoto Bulletin of Islamic Area Studies 1 (2): 38-53.

Rahman, M. Miazur. 2010. "Islamic Microfinance Program and Its Impact on Rural Poverty Alleviation.” International Journal of Banking and Finance 7 (1): 119-138.

Rahman, Sayma, Rafiqul Bhuyan Rafiq, and Mohammad A. Momen. 2009. "Impact of Microcredit Programs on Higher Income Borrowers: Evidence from Bangladesh.” International Business \& Economics Research Journal 8 (2): 119-124.

Rajendran, K., and R.P. Raya. 2010. "Impact of Micro Finance - An Empirical Study on the Attitude of SHG Leaders in Vellore District (Tamil Nadu, India).” Global Journal of Finance and Management 2 (1): 59-68.

Reardon, Thomas, and Stephen A. Vosti. 1995. "Links between Rural Poverty and Environment in Developing Countries: Asset Categories and Investment Poverty." World Development 23 (9): 1495-1506.

Reddy, A Govardhana, Nalla Bala Kalyan Kumar, and Padmavathi. 2013. "Impact of Environmental Resources Degradation on Tirupati." International Journal of Business and Management Research 3 (2): 29-34.

Ritchie, Jane, and Jane Lewis, eds. 2003. Qualitative Research Practice. London: Sage Publications.

Roberts, Peter W. 2013. "The Profit Orientation of Microfinance Institutions and Effective Interest Rates.” World Development 41: 120-131.

Robinson, Marguerite S. 2002. The Microfinance Revolution Volume 2: Lessons from Indonesia. Washington, D.C.: The World Bank.

Rouf, Kazi Abdur. 2012a. "Green Economics and Biodiversity through Green Micro-financing.” Prime Journal of Business and Administration Management 2 (4): 513-520.

2012b. “Green Microfinance Promoting Green Enterprise Development.” International Journal of Research Studies in Management 1 (1): 85-96.

Ruben, R., and L. Clercx. 2003. "Rural Finance, Poverty Alleviation, and Sustainable Land Use: The Role of Credit for the Adoption of Agroforestry Systems in Occidental Honduras.” Journal of Microfinance 5 (2): 77-100.

Saad, Norma Md. 2012. "Microfinance and Prospect for Islamic Microfinance Products: The Case of Amanah Ikhtiar Malaysia. Advances in Asian Social Science 1 (1): 27-33.

Sandberg, Joakim. 2012. "Mega-Interest on Microcredit: Are Lenders Exploiting the Poor?" Journal of Applied Philosophy 29 (3): 169-185. doi: 10.1111/j.1468-5930.2012.00560.x

Scott, Andrew. 2000. "Small-scale Enterprises and the Environment in Developing Countries." In Small and Medium-sized Enterprises and the Environment: Business Imperatives, edited by Ruth Hillary, 276-288. Sheffield: Greenleaf. 
Seeberg-Elverfeldt, Christina, Stefan Schwarze, Heiko Faust. 2010. "Institutions for Environmental Service Payment Programmes - Evidence of Community Resource Management Arrangements in Central Sulawesi, Indonesia.” In Tropical Rainforests and Agroforests under Global Change - Ecological and Socio-economic Valuations, edited by Teja Tscharntke, Christoph Leuschner, Edzo Veldkamp, Heiko Faust, Edi Guhardja, and Arifuddin Bidin, 431-446. Berlin: Springer.

Seibel, Hans Dieter. 2008. "Islamic Microfinance in Indonesia: The Challenge of Institutional Diversity, Regulation, and Supervision.” Journal of Social Issues in Southeast Asia 23 (1): 86-103.

Seibel, Hans Dieter, Wahyu Dwi Agung. 2006. “Islamic Microfinance in Indonesia.” Working Paper 2006 (2). Development Research Center, University of Cologne. http://hdl.handle.net/10419/23656.

Shortall, Jessica. 2009. "Microfinance and Climate Change: Can MFIs Promote Environmental Sustainability?” Speaker's Corner Summary Report. United States Agency for International Development.

Simpson, Mike, Nick Taylor, and Karen Barker. 2004. "Environmental Responsibility in SMEs: Does it Deliver Competitive Advantage?” Business Strategy and the Environment 13 (3): 156-171.

Singh, Kultar. 2007. Quantitative Social Research Methods. New Delhi: Sage Publications India.

Sirageldin, Ismail. 2000. "Elimination of Poverty: Challenges and Islamic Strategies.” Islamic Economic Studies 8 (1): 1-16.

Siwar, Chamhuri, and Mohd. Yusof Kasim. 1997. "Urban development and urban poverty in Malaysia.” International Journal of Social Economics 24 (12): 1524-1535.

Smolo, Edib, and Abdul Ghafar Ismail. 2011. "A Theory and Contractual Framework of Islamic Micro-financial Institutions’ Operations.” Journal of Financial Services Marketing 15 (4): 287-295.

Steel, Brent S. 1996. "Thinking Globally and Acting Locally? Environmental Attitudes, Behavior and Activism.” Journal of Environmental Management 47: 27-36.

Stiglitz, Joseph E. 1990. "Peer Monitoring and Credit Market." The World Bank Economic Review 4 (3): 351-366.

Sugema, Iman, Toni Bakhtiar, and Jaenal Effendi. 2010. "Interest Versus Profit-Loss Sharing Credit Contract: Efficiency and Welfare Implications.” International Research Journal of Finance and Economics 45: 1450-2887.

Takahashi, Kzushi, Takayuki Higashikata, and Kazunari Tsukada. 2010. "The Short-Term Poverty Impact of Small-Scale, Collateral-Free Microcredit in Indonesia: A Matching Estimator Approach.” The Developing Economies 48 (1): 128-155.

Tang, Tao. 2000. "Slope Profile Analysis and Classification on Limestone Residual Hills in Guilin, China.” Middle States Geographer 33: 40-53.

Taylor, John K., and Cheryl Cihon. 2004. Statistical Techniques for Data Analysis. Boca Raton: CRC Press. 
Taylor-Powell, Ellen, and Ellen Henert. 2008. "Developing a logic model: Teaching and Training Guide.” Program Development and Evaluation, University of WisconsinExtension. http://www.uwex.edu/ces/pdande/evaluation/pdf/lmguidecomplete.pdf.

Ter Haar, Gerrie, and Stephen Ellis. 2006. "The Role of Religion in Development: Towards a New Relationship between the European Union and Africa.” The European Journal of Development Research 18 (3): 351-367.

Thurmond, Veronica A. 2001. “The Point of Triangulation.” Journal of Nursing Scholarship 33 (3): 253-258.

Tilak, Jandhyala B. G. 1989. "Education and Its Relation to Economic Growth, Poverty, and Income Distribution.” World Bank Discussion Papers WDP-46. The World Bank.

Tobin, Gerard A., and Cecily M. Begley. 2004. "Methodological Rigour within a Qualitative Framework.” Journal of Advanced Nursing 48 (4): 388-396.

Tobey, J., and E. Torell. 2006. "Coastal Poverty and MPA Management in Mainland Tanzania and Zanzibar.” Ocean and Coastal Management 49: 834-854.

Tscharntke, Teja, Christoph Leuscher, Edzo Veldkamp, Heiko Faust, Edi Guhardja, and Arifuddin Bidin, eds. 2010. Tropical Rainforests and Agroforest under Global Change: Ecological and Socio-economic Valuations. Berlin: Springer.

Tscharntke, Teja, Yann Clough, Shonil A. Bhagwat, Damayanti Buchori, Heiko Faust, Dietrich Hertel, Dirk Hölscher, Jana Juhrbandt, Michael Kessler, Ivette Perfecto, Christoph Scherber, Götz Schroth, Edzo Veldkamp, Thomas C. Wanger. 2011. "Multifunctional Shade-tree Management in Tropical Agroforestry landscapes - a Review." Journal of Applied Ecology 48 (3): 619-629.

Uddin, Mohammad Main. 2008. "Credit for the Poor: The Experience of Rural Development Scheme of Islami Bank Bangladesh Ltd.” The Journal of Nepalese Business Studies 5 (1): 62-75.

UNDP (United Nation Development Program). 2012. Poverty Reduction: Scaling up Local Innovations for Transformational Chance. New York. USA. http://www.undp.org/content/dam/undp/library/Poverty\%20Reduction/Participatory\%20 Local\%20Development/Bangladesh_D10_web.pdf

UNEP (United Nations Environment Program Finance Initiative). 2007. Green Financial Products and Services: Current Trends and Future Opportunities in North America. Toronto: ICF Consulting Canada. http://www.unepfi.org/fileadmin/documents /greenprods_01.pdf.

Van Tassel, Eric. 1999. “Group Lending under Asymmetric Information.” Journal of Development Economics 60: 3-25.

Watkins, Todd A., and Karen Hicks, eds. 2009. Moving Beyond Storytelling: Emerging Research in Microfinance. Contemporary Studies in Economics and Financial Analysis 92. Bingley: Emerald Group Publishing.

Wenner Mark D., Norman Wright, and Abhishek Lal. 2004. "Environmental Protection and Microenterprise Development in the Developing World: A Model Based on the Latin American Experience.” Journal of Microfinance 6 (1): 95-122. 
White, Michael J and Lori M. Hunter. 2009. "Public Perception of Environmnetal Issues in a Developing Setting: Environmental Concern in Coastal Ghana.” Social Science Quarterly 90 (4): 960-982.

Widiyanto, Siti Mutamimah, and Hendar. 2011. "Effectiveness of Qard al Hasan Financing as a Poverty Alleviation Model.” Economic Journal of Emerging Markets 3 (1): 27-42.

Widiyanto bin Mislan Cokro Hadisumarto, Abdul Ghafar B. Ismail. 2010. "Improving the effectiveness of Islamic micro-financing: Learning from BMT experience.” Humanomics, 26 (1): 65-75.

Williamson, D., and G. Lynch-Wood. 2001. "A New Paradigm for SME Environmental Practice.” The TQM Magazine 13 (6): 424-432.

Wilson, Kathryn. 2002. “The effects of school quality on income." Economics of Education Review 21 (6): 579-588.

Wilson, Rodney. 2007. "Making Development Assistance Sustainable through Islamic Microfinance.” IIUM Journal of Economics and Management 15 (2): 197-217.

World Bank. 1995. Pakistan Poverty Assessment Report No. 14397-PAK. Washington, D.C: The World Bank.

- 2008. Poverty and the Environment: Understanding Linkages at the Household Level. Washington, D.C.: The World Bank.

Yunus, Muhammad. 2007. Creating a World without Poverty: Social Business and the Future of Capitalism. New York: Public Affairs.

Zeller, Manfred, Cécile Lapenu, Bart Minten, Eliane Ralison, Désiré Randrianaivo, and Claude Randrianariso. 2000. "Pathways of Rural Development in Madagascar: An Investigation of the Critical Triangle of Environmental Sustainability, Economics Growth, and Poverty Alleviation.” FCND Discussion Paper 82. http://www.ifpri.cgiar. org/sites/default/files/publications/fcndp82.pdf. 


\title{
Curriculum Vitae
}

\author{
Name \\ : Jaenal Effendi \\ Place, date of birth \\ : Pasuruan - Indonesia, July 29, 1974 \\ Address \\ : Department of Economics and Development Studies, Bogor \\ Agricultural University, Gedung FEM Lt. 2, Jl. Kamper, Kampus IPB \\ Dramaga, Bogor, West Java - Indonesia \\ E-mail: jaenfendi@gmail.com, jaen_nur@yahoo.com \\ Nationality \\ :Indonesian

\section{Education} \\ Winter Semester 2010 : PhD student at the Department of Human Geography, Georg- \\ August University of Göttingen, Germany \\ $2003-2005$ \\ : Master Program in Islamic Economics, State Islamic University, \\ Syarif Hidayatullah, Jakarta, Indonesia \\ $1994-1999$ \\ : Bachelor degree at the University of Tribakti Kediri, East Java, \\ Indonesia \\ Work Experience \\ 2006 - present \\ : Lecturer at the Department of Economics, Faculty of Economic \\ and Management, Bogor Agricultural University (IPB), Bogor, \\ West Java, Indonesia
}

\section{Scientific Work}

1. Effendi, Jaenal : The Islamic Microfinance' Impact in Reducing Poverty and Increasing Environmental Awareness "Jahrestagung 2011 des AK Südostasien der DGfG" Rauschholzhausen, Germany, June 24-26, 2011.

2. Effendi, Jaenal., Meylani, W., and Faust, Heiko.: Islamic Microfinance; Charity Capital Zakat, Infaq, Shadaqah role on Poverty alleviation and Empowerment. Contributed Paper for International Zakat Conference, Bogor, Indonesia, July 19-21, 2011.

3. Effendi, Jaenal and Faust, Heiko: The Role of Islamic Microfinance on Poverty Alleviation and Environmental Awareness in Indonesia, Resilience of Agricultural System Against Crisis, University of Göttingen, Germany, Tropentag International Conference, 2012. 